\title{
Evaluation of Potential Indicators for Soil Quality in Savanna Soils in Northern Ghana \\ (West Africa)
}

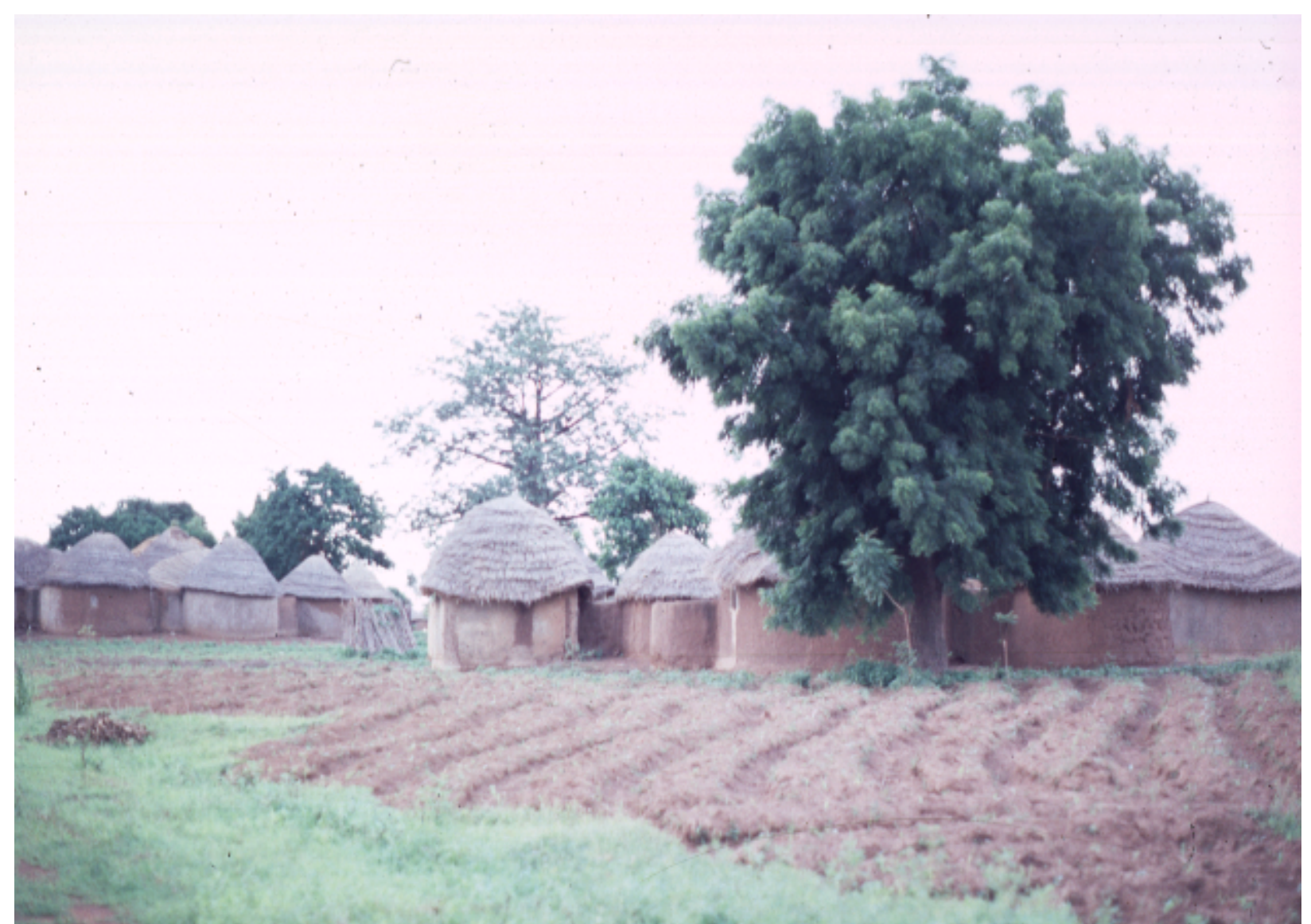

Cheshegu, Northern Ghana (FUGGER, 1995)

Dissertation zur Erlangung des Doktorgrades der Fakultät für Agrarwissenschaften der Georg-August-Universität Göttingen

vorgelegt von

\section{Wolf-Dietrich Fugger}

geboren in Mosbach

Göttingen, Juli 1999 
D7

1. Referent: Prof. Dr. P. L. G. Vlek

2. Koreferent: Prof. Dr. H. Fölster

Tag der mündlichen Prüfung: 08. 07. 1999 
1 INTRODUCTION 1

2 STATE OF THE ART $\quad 4$

2.1 The concept of soil quality 4

2.2 Soil organic matter 5

2.3 Soil microbial biomass 6

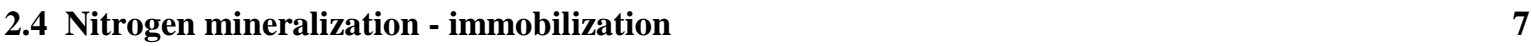

2.5 Nitrogen availability indices 9

2.5.1 Estimation of nitrogen mineralization by aerobic laboratory incubation 9

2.5.2 Evaluation of ammonium-N production under waterlogged conditions 9

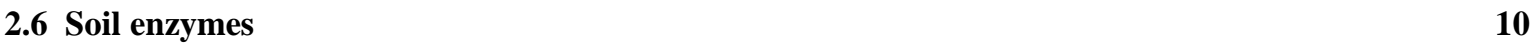

2.7 Limitations of soil quality and microbial indicators 12

3 BACKGROUND INFORMATION TO THE STUDY AREA 14

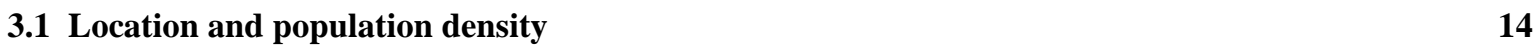

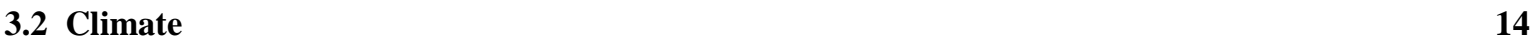

$\begin{array}{ll}3.3 \text { Soils } & 16\end{array}$

$\begin{array}{ll}\text { 3.4 Agriculture in the Northern Savanna Zones } & 17\end{array}$

4 MATERIALS AND METHODS 20

4.1 Location and climate of the experimental sites 20

4.2 Selection of study sites and experimental design 21

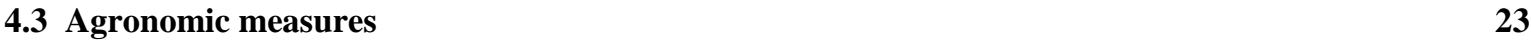

4.4 Plant analysis $\quad 26$

4.4.1 Plant sampling and processing 26

4.4.2 Plant nutrient analysis 26

4.5 Sampling, processing and analysis of soil 27

4.5.1 Soil mineral N 27

4.5.2 Aerobic incubation method 28

4.5.3 Anaerobic incubation method 28

4.5.4 Soil microbial biomass 28

4.5.5 Soil enzyme analysis $\quad 29$

4.5.5.1 Acid and alkaline phosphatase activity 29

4.5.5.2 B-Glucosidase activity 29

$\begin{array}{lr}\text { 4.5.5.3 Protease activity } & 29\end{array}$

$\begin{array}{ll}\text { 4.6 Statistics } & 30\end{array}$ 


\section{RESULTS AND DISCUSSION}

5.1 Characterization of the experimental sites

5.1.1 Initial soil characteristics in June 1993

5.1.2 Maize grain yields 36

5.1.3 Maize nutrient concentration and nutrient uptake

5.1.4 Conclusions on maize yields and nutrient uptake

5.2 Dynamics of chemical soil parameters under maize from 1993 until 1995

5.2.1 Soil $\mathrm{pH}$

5.2.2 Soil organic carbon

5.2.3 Total nitrogen

5.2.4 Soil C-N-ratio 49

5.2.5 Bray-I phosphorus (available P)

5.2.6 Soil organic phosphorus

5.2.7 Base saturation and effective soil cation exchange capacity (CEC) 56

5.2.8 Exchangeable $\mathrm{K}$

5.2.9 Exchangeable $\mathrm{Ca}$ and $\mathrm{Mg}$

5.2.10 Extractable sulfate-S and exchangeable manganese

5.3.1 Soil microbial biomass

5.3.2 $\mathrm{C}_{\mathrm{mic}}-\mathrm{C}_{\text {org }}$-ratio

5.3.3 Acid phosphatase activity

5.3.4 Alkaline phosphatase activity

5.3.5 ß-Glucosidase activity

5.3.6 Protease activity

5.3.7 Correlations between microbial parameters and soil and plant parameters

5.3.8 Microbiological parameters as soil quality indices

\subsection{Mineral nitrogen}

5.4.1 Soil ammonium content during three years from June 1993 to October 1995

5.4.2 Dynamics of ammonium $\mathrm{N}$ in the soil profile $(0-90 \mathrm{~cm})$ under maize 86

5.4.3 Soil nitrate content during three years from June 1993 to October $1995 \quad 88$

5.4.4 Dynamics of nitrate $\mathrm{N}$ in the soil profile $(0-90 \mathrm{~cm})$ under maize $\quad 88$

5.4.5 The use of preseason $\mathrm{NH}_{4}{ }^{+}, \mathrm{NO}_{3}{ }^{-}$and $\mathrm{N}_{\text {min }}$ as a measure of plant available $\mathrm{N} \quad 91$

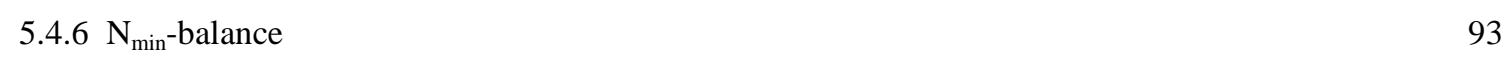

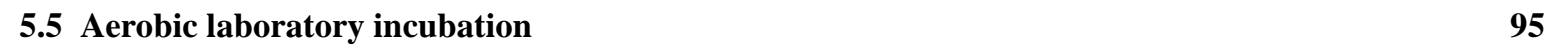

5.5.1 Cumulative mineralization of $\mathrm{N}$ after 84 days of aerobic incubation 95

5.5.2 Model fitting 99

5.5.3 The use of $\mathrm{N}_{0}$ as a measure of potential $\mathrm{N}$ mineralization in the study soils 101

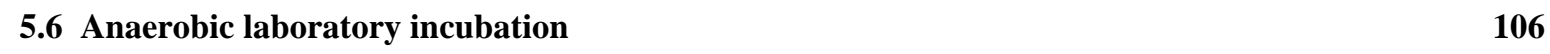

$\begin{array}{ll}5.7 \text { Comparison between aerobic and anaerobic incubation studies } & 110\end{array}$ 


\section{GENERAL DISCUSSION AND CONCLUSIONS}

6.1 Identification of soil processes $\quad \mathbf{1 1 2}$

6.1.1 Soil quality as affected by land use history 112

6.1.2 Relationship between maize yield of the first season and initial soil quality 117

6.1.3 Soil quality as affected by fertilizer management of sequential maize cropping 120

$\begin{array}{ll}\text { 6.1.4 Biochemical and biological parameters as soil quality indicators } & 127\end{array}$

$\begin{array}{ll}\text { 6.2 Relationships between soil quality and sustainable crop production } & 128\end{array}$

6.3 Modifications of current land-use systems for soil fertility maintenance 130

$\begin{array}{ll}\text { 6.4 Conclusions } & 133\end{array}$

7 SUMMARY 137

8 ZUSAMMENFASSUNG $\quad 144$

9 REFERENCES 152

10 ANNEX 163

$\begin{array}{ll}\text { MAP OF GHANA } & 185\end{array}$

Acknowledgements

Cirriculum vitae 


\section{List of Abbreviations}

\section{ANOVA}

A. S. E.

$\mathrm{Ca}$

CEC

$\mathrm{CH} 1$

$\mathrm{CH} 2$

$\mathrm{C}_{\text {mic }}$

$\mathrm{cm}$

$\mathrm{cmol}^{+} \mathrm{kg}^{-1}$

$\mathrm{C}_{\text {org }}$

CV

df

DM

g

ha

$\mathrm{K}$

$\mathrm{k}_{0}$

$\mathrm{kg}$

LSD

$\mathrm{Mg}$

$\mathrm{mg}$

$\mathrm{Mn}$

Mo

$\mathrm{N}$

n

n.d.

$\mathrm{N}_{0}$

$\mathrm{NH}_{4}^{+}$

$\mathrm{N}_{\text {min }}$

$\mathrm{NO}_{2}{ }^{-}$

$\mathrm{NO}_{3}{ }^{-}$

ns

$\mathrm{N}_{\mathrm{t}}$

$\mathrm{N}_{\text {tot }}$

$\mathrm{P}$

$p$

pot- $\mathrm{N}_{\min }$

$\mathrm{r}$

$r^{2}$

SARI

sd

SMB

SOM

$\mathrm{t}$

vs

$\mathrm{Zn}$

$\mu \mathrm{g}$ analysis of variance

asymptotic standard error

Calcium

cation exchange capacity

experimental field not degraded

experimental field degraded

soil microbial biomass

centimeter

centimole charge per kilogram

total organic carbon

coefficient of variance

degrees of freedom

dry matter

gram

hectare

Potassium

mineralization rate constant after aerobic incubation

kilogram

least significant difference

Magnesium

miligram

Manganese

Molybdenum

Nitrogen

number of replications

not determined

potentially mineralizable $\mathrm{N}$ based on aerobic incubation

ammonium

mineral Nitrogen

nitrite

nitrate

not significant

cumulative mineral $\mathrm{N}$ at time $\mathrm{t}$ in days

total nitrogen

Phosphorus

probability

potentially mineralizable $\mathrm{N}$ based on anaerobic incubation

Pearson's correlation coefficient

coefficient of determination

Savanna Agricultural Research Institute

standard deviation

soil microbial biomass

soil organic matter

time

versus

Zinc

microgram 


\section{$1 \quad$ Introduction}

In many parts of the developing world sustainable land-use is threatened by environmental degradation associated with increasing population. In Ghana the population increased from 8.6 Mio in 1970 to 17.8 Mio in 1996. The annual population growth rate from 1993 - 2000 is estimated at $3.0 \%$ (FAO Stat online, 1998). Due to increasing demand for food during 1970 - 1995 the area planted to food crops increased by $10 \%$ (FAO Stat online, 1998). However, because of the scarcity of suitable arable land, the population growth is accompanied by an increased use of marginal soils. Consequently, West Africa's soil resource, which in general, is fragile and easily degraded, has been deteriorating at an alarming rate in most parts of the sub-region (VLEK, 1993).

Land degradation and declining soil fertility are considered the main causes of stagnation or decline in agricultural production (UNEP-ISRIC, 1991). During the past decades soils have continuously been mined of nutrients, and soil organic matter content decreased to very low levels. Soil degradation, as a result of overexploitation, deforestation, and desertification has negative impacts not only on agricultural productivity, but also on employment, rural welfare, and food security. Moreover, it may result in irreparable environmental damage, at least at an human time scale. Consequently, food shortages are common in some regions of West Africa. The sub-region is projected to account for $67 \%$ of the total food deficit in SSA by the year 2000 (IFDC, 1994). Projections from International Food Policy Research Institute (IFPRI) for the year 2000 estimate the net deficit in food production at 50 million $\mathrm{t}$ or $25 \%$ of the food needs (VLEK, 1993). Crop yields in Africa are amongst the lowest in the world. In 1996 average yield of maize was $1.1 \mathrm{t} \mathrm{ha}^{-1}$ for Africa as compared to $2.5 \mathrm{t} \mathrm{ha}^{-1}$ for Asia and $2.5 \mathrm{t} \mathrm{ha}^{-1}$ for South America (FAO Stat online, 1998). In northern Ghana, in 1994 average yields of maize ranged between 0.9 and $1.4 \mathrm{t} \mathrm{ha}^{-1}$ (MOA, 1995).

The loss of productivity is often related to the loss of soil nutrients and soil organic matter as a result of cultivation (VLEK et al., 1997). Quantifications of nutrient losses by STOORVOGEL and SMALING (1990) showed that soil nutrients are depleted by annual food crops at high rates in low-input agricultural systems on subsistence basis in West Africa. According to SANCHEZ et al. (1996) soil fertility depletion in small holders' farms is the main limiting biophysical factor responsible for the declining per capita food production of sub-Saharan Africa. In the savanna zone of northern Ghana the problems of inadequate 
agricultural production and the high rate of population growth (3\%) still remain unsolved. Some farmers' practices which have a negative impact on soil fertility such as short fallow periods, nutrient export, land clearing by bush burning and overgrazing by animals are common (RUDAT and QUARSHIE, 1993). In the more densely populated areas, the farm land is becoming scarce. Small scale farmers in northern Ghana mine nutrients from the soil to meet low levels of crop production. As a consequence, negative balances of major nutrients (N, P, K) for Ghana are estimated for the year 2000 (STOORVOGEL and SMALING, 1990). The use of mineral fertilizers to compensate for nutrient depletion has been reduced since prices increased drastically during the recent years as a result of abolishing fertilizer subsidies. In general, it can be assumed that in future the majority of the farmers will not be in the position to apply more mineral fertilizer to cope with soil fertility problems. It seems to be likely that soil fertility in subsistence farmers' fields will further decline if other interventions are not undertaken (ALBERT, 1996).

The fertility of soil is its productive potential, or capacity to produce crops on a sustained basis. From the scientific point of view loss of soil fertility and soil degradation is a complex interaction between physical, chemical and microbial soil properties. In managing tropical soils for improved productivity much emphasis was placed on enhancing soil physical and chemical fertility whereas less is known of the associated changes in soil microbiological properties and how such changes influence plant productivity and sustainability of a system (DORAN et al., 1996; YAKOVCHENKO, 1996; WICK, et al., 1998). Soil degradation is often equated with physical and chemical soil properties which have been also used as indicators of soil degradation (LAL et al., 1990; HulugaLLE, 1992; WICK, et al., 1998). However, even after optimizing the soil chemical and physical properties, expected high crop yields were not obtained on many soils in West-Africa, as direct correlations between soil organic matter and nutrient status with crop yield were not always evident (WICK, et al., 1998).

Recent literature reflects considerable interest in the concept of soil quality as it relates to sustainable production in agricultural systems (LARSON and PIERCE, 1991; PARR et al., 1992; Reganold et al., 1993; DORAN and PARKIN, 1994; YAKOVCHENKO, 1996; McCARTHY and MeISINGER, 1997). The traditional concept of soil quality has focused on crop yield as an important indicator of system productivity, which is in part dependent on soil quality. Crop yield integrates several interacting factors however, crop yield alone 
has proved to be an incomplete measure of system productivity. Thus, for determining soil fertility and sustainability of a system soil quality is considered as an integral factor of agricultural productivity (DORAN and PARKIN, 1994; YAKOVCHENKO, 1996). Consequently, the search for soil quality indices is an attempt to classify soil conditions and to relate these conditions to land use history. From this information it may be possible to determine what uses of soils are better for the long-term goals of agriculture and society.

Growing awareness of soil degradation has prompted the search for reliable measure of soil quality. This requires the selection of the soil properties most sensitive to changes in management practices (DORAN and PARKIN, 1994; ElliotT et al., 1996). Soil organic matter changes very slowly, and therefore many years may be required to measure changes resulting from anthropogenic impact. Thus, the study of sensitive biomarkers of soil degradation is of great importance (GARCIA and HERNANDEZ, 1997). There is growing evidence that soil biological properties may hold potential as early and sensitive indicators of soil ecological stress or restauration. For these reasons they are considered to be appropriate for estimating soil quality (DORAN and PARKIN, 1994; ElLIOTT et al., 1996; YAKOVCHENKO, 1996). In accordance with this approach various biological and biochemical properties such as soil microbial biomass, soil enzyme activities and nitrogen mineralization indices were determined to develop a soil quality index that might be useful both for detecting soil degradation and for estimating the degree of recovery of degraded soils. The enzymes covered are those important in $\mathrm{C}, \mathrm{N}$ and $\mathrm{P}$ cycling in soils.

\section{Objectives}

The general objective was to improve the understanding of nutrient cycling in agroecosystems in the savanna region of northern Ghana, West Africa. To evaluate the potential for sustainable productivity, soil microbiological and soil biochemical parameters were linked with soil fertility and soil quality conditions as well as with crop productivity. In this respect, the study was undertaken on contrasting soils with differential land use history to identify those parameters that are affected most by soil and crop management. The main questions were:

- Is soil degradation a result of nutrient depletion and which nutrient is the most limiting?

- Is soil degradation a result of a change in soil microbial activities?

- Is it possible to use microbial soil parameters as indicators of soil quality? 


\section{State of the Art}

\subsection{The concept of soil quality}

The concept of soil quality has gained increasing interest in the literature (DORAN and PARKIN, 1994; JORDAN et al., 1995; YAKOVCHENKO et al., 1996; GARCIA and HERNANDEZ, 1997; TRASAR-CEPEDA et al., 1998). Traditionally, soil quality has been associated mainly with soil productivity (YAKOVCHENKO et al., 1996). Today soil quality is seen as the key factor for agronomic, ecological and macro- and microeconomic sustainability. In terms of sustainability soil quality has been defined as the capacity of a soil system to function as a filter, buffer and transformer of water, minerals and energy so that crop production is maximized and environmental degradation is minimized (DORAN and PARKIN, 1994).

Soil quality depends on a large number of physical, biological and biochemical soil properties, and its characterization requires the selection of the properties most sensitive to management practices (LARSON and PIERCE 1991; Elliott, 1994 as cited by TRESAR-CEPEDA et al., 1998). Identification of suitable indicators for soil quality assessment depends on the ability of any approach to consider the multiple components of soil function, in particular, productivity and environmental protection. Many indicators have been proposed for assessing the soil quality of agricultural soils. Some workers have suggested that chemical criteria such as total organic $\mathrm{C}$ and $\mathrm{N}$ may indicate soil quality (ARSHAD and COEN, 1992), and others have suggested that biological criteria such as soil microbial biomass (VISSER and PARKINSON, 1992; WICK, 1998) and soil enzyme activities may prove to be sensitive indicators of soil quality (BECK, 1984; DIEKMANN, 1997; WICK, 1998; TRESAR-CEPEDA et al., 1998). LARSON and PIERCE (1991) proposed a minimum data set including soil texture, soil organic matter, soil $\mathrm{pH}$, soil nutrient status, bulk density, electrical conductivity and rooting depth to measure soil quality and its changes due to soil management practices. This list was extended with biological variables of soil quality, such as microbial biomass $\mathrm{C}$ and $\mathrm{N}$, and soil respiration by DORAN and PARKIN (1994). Biological properties fulfill these requirements and are also sensitive to environmental stress. Moreover, these parameters respond to changes in soil management practices (ElliotT et al., 1996; DieKMANn, 1997; Wick et al., 1998; TrEsAR-CEPEDA et al., 1998). Therefore, biological and biochemical soil properties provide a means for assessing the degree of soil degradation and soil quality (ELLIOTT et al., 1996; YAKOVCHENKO et al., 1996; DIEKMANN, 1997; WICK et al., 1998, TRESAR-CEPEDA et al., 1998). 


\section{$2.2 \quad$ Soil organic matter}

Soil organic matter (SOM) is a complex mixture of living, dead, and decomposing material, and complex organic substances. It plays a key role in terrestrial ecosystem development and functioning (SMITH et al., 1993). Therefore, it is important to gain a better understanding of the influence of different management practices on the quantity and quality of SOM in agricultural soils (McCARTHY and MEISINGER, 1997). The maintenance of SOM is essential because of its central role in stabilizing the soil structure, fertility, and biological activity in the soil ecosystem (PARR et al., 1992).

In agriculturally used soils, residues from plants, soil organisms and manure are decomposed and transformed into humic and non-humic substances. These processes are mainly regulated by soil microorganisms. The easily degradable organic compounds such as sugars, starches and simple proteins are preferred as energy sources by many microorganisms (BURNS and MARTIN, 1986). However, it is not clear whether a highly active microbial biomass results in a typical SOM or whether the type of organic matter composition affects the microbial biomass (BEYER, 1995).

Several models have been developed to describe SOM-dynamics in soil-crop systems. A common approach is to separate SOM into conceptual pools with (1) active, (2) slow and (3) passive fractions (PARTON et al., 1987). The living SOM pool, or the soil microbial biomass (SMB) is considered to be part of the active SOM.

Quantification of various $\mathrm{C}$ and $\mathrm{N}$ pools in soil can provide valuable information about the impact of management practices on the quality of SOM in agricultural soils. The quality and quantity of SOM normally changes at slow rates which are difficult to detect in the short term because of the large pool-size of SOM and the spatial heterogeneity of soils. However, SMB as an active fraction of the SOM responds much more rapidly than total SOM to changes in management, climate etc. For that reason, microbial carbon content $\left(\mathrm{C}_{\mathrm{mic}}\right)$ and the ratio between microbial and organic carbon $\left(\mathrm{C}_{\mathrm{mic}}-\mathrm{C}_{\mathrm{org}}\right.$-ratio) have been proposed as indicators of the state and changes of total SOM (Dick, 1992; Powlson, 1994; PANKHURST et al., 1995). Other authors use the $\mathrm{C}_{\text {mic }}-\mathrm{C}_{\text {org }}$-ratio as an normalized indicator for changes in metabolic activitiy which might be affected by changing management conditions and climate (ANDERSON and DOMSCH, 1989, SPARLING, 1992, WEIGAND et al., 1995). 


\subsection{Soil microbial biomass}

The soil microbial biomass (SMB) measurements have been widely used to assess the effects of human practices on the quality of soils (MARTENS, 1995; WARDLE, 1998). It has been defined as the part of SOM that constitutes living microrganisms smaller than $5-10 \mu \mathrm{m}^{3}$. It is mainly consisting of bacteria, fungi, actinomycetes, algae, protozoa, and some nematodes (ROPER and GUPTA, 1995). The size of microbial biomass generally depends on SOM level (GoyAL et al., 1993) and constitutes only 1 - $3 \%$ of total soil C across a wide range of locations and soil types (SMITH and PAUL, 1990).

By decomposition of organic materials, heterotrophic microorganisms use the C-H-bound energy to support their maintenance and growth. In the C-limited soil system, available C in organic materials entering the soil is the driving force behind these processes but other essential nutrient elements (particularly $\mathrm{N}, \mathrm{P}, \mathrm{S}$ ) are also important. Under suitable environmental conditions the decomposition rate will be mainly controlled by (1) the resource quality, i.e. the degradability of organic compounds and

(2) the population dynamics and metabolic activity of the decomposers.

The SMB contributes to the maintenance of soil fertility and soil quality by representing a labile pool of C and nutrient elements (ELLIOTT et al., 1996). According to MARTENS (1995), 200 - $1000 \mu \mathrm{g}$ microbial $\mathrm{C} \mathrm{g}^{-1}$ soil are often found in agricultural soils. The SMB contains $100-600 \mathrm{~kg} \mathrm{~N}$ and $50-300 \mathrm{~kg} \mathrm{P} \mathrm{ha}^{-1}$ in the upper $30 \mathrm{~cm}$ of soil (MARTENS, 1995). If the nutrients stored in SMB are released the amounts of nutrients often exceed the annual application of nutrients with mineral fertilizer to soils in tropical farming systems. The release or immobilization of nutrients depends mainly on the population dynamics of the microorganisms. Growth of heterotrophic SMB and immobilization of nutrients is promoted by rhizodeposits, plant debris and high resource quality (i.e. low $\mathrm{C} / \mathrm{N}$ ratio). The release of nutrients is the consequence of microbial death and concomitant mineralization of dead microbial biomass. The importance of these processes in terrestrial nutrient cycles led to efforts to quantify the amount and turnover rate of the SMB (MARTENS, 1995). Immobilization protects mobile forms of nutrients such as $\mathrm{NO}_{3}{ }^{-}$from leaching. However, it may also restrict their availability to plants (HAGGAR et al., 1993). According to LIANG and MACKENZIE (1996) immobilization by SMB was found to be a more important sink for fertilizer $\mathrm{N}$ than leaching and denitrification. They considered higher $\mathrm{N}$ immobilization rates to be a major mechanism to increase organic $\mathrm{N}$ levels in soils. 


\subsection{Nitrogen mineralization - immobilization}

For many years much emphasis was laid on research in relation to $\mathrm{N}$ mineralization (BURKET and DiCK, 1998). Although global $\mathrm{N}$ reserves are large (CAMPBELL, 1978), $\mathrm{N}$ is the major limiting element in many terrestrial ecosystems. This is due to the abundance of $\mathrm{N}_{2}$ and organic- $\mathrm{N}$ forms, which must be made available to higher plants through microbial fixation and mineralization, respectively (SPRENT, 1987; BOHLOOL et al., 1992). The balance between the microbially mediated processes of mineralization and immobilization is central to the flow and availability of mobile forms of $\mathrm{N}$ in the soil (JARVIS, 1996). Much research effort has been devoted to predict rates in the field from incubation studies under controlled conditions. This has been recently reviewed by POWLSON et al. (1994). However, it is not yet possible to provide adequate reliability for prediction of $\mathrm{N}$ availability and for decisions on fertilizer requirements and recommendations (BURKET and DICK, 1998).

Most mineral surface soils $(0-30 \mathrm{~cm})$ contain 0.02 to $0.4 \%$ of N, and 97 to $99 \%$ occurs as nitrogenious organic compounds in SOM (KEENEY, 1982a; DAHNKE and JOHNSON, 1990). If 1 to $3 \%$ of this organically bound $\mathrm{N}$ are mineralized annually, 8 to $120 \mathrm{~kg}$ of $\mathrm{N} \mathrm{ha}^{-1}$ are released in a form usable by plants. Plant roots take up $\mathrm{N}$ from the soil solution principally as $\mathrm{NO}_{3}{ }^{-}$and $\mathrm{NH}_{4}{ }^{+}$ions. Mineral $\mathrm{N}$ can originate from many sources including fertilizer $\mathrm{N}$ and mineralization of organic $\mathrm{N}$ from SOM, crop residues, and organic wastes (KEENEY, 1982a; MEISINGER, 1984). Since $\mathrm{NH}_{4}$ is converted to $\mathrm{NO}_{3}$ in most aerobic soils, $\mathrm{NO}_{3}$ is usually the predominant form of available $\mathrm{N}$ in the plant root zone of arable soils.

Soil microorganisms are the engines of organic N transformations. Organic N (e. g. protein and as part of humic compounds) is converted by microbial decomposition to ammonia. Nitrogen mineralization is done by a large number of heterotrophic microorganisms. The first step of protein hydrolysis is the release of amino acids, which are then hydrolyzed under aerobic or anaerobic conditions to ammonia (ALEF, 1995a).

Ammonification is associated with the activity of living SMB which assimilates $\mathrm{NH}_{4}^{+}$ (immobilization). Mineralization and immobilization (conversion of inorganic $\mathrm{N}$ forms into organic forms.) occur simultaneously. The net effect depends on available mineral $\mathrm{N}$ and metabolizable organic $\mathrm{C}$ at micro sites in the soil where the microbial attack occurs. The most common explanation for immobilization of $\mathrm{NH}_{4}{ }^{+}$is that high $\mathrm{C}$ availability and low $\mathrm{N}$ content of crop residues causes $\mathrm{NH}_{4}{ }^{+}$-immobilization due to $\mathrm{N}$-demand by soil microorganisms (HART et al., 1994). 
The rate of mineralization also depends on the $\mathrm{C} / \mathrm{N}$ ratio, lignin and polyphenolics content of the organic compound; high rates generally occur at low C/N ratios (ALEF, 1995a). Except for the hydrolysis of urea by extracellular urease, the ammonification is bound to the metabolism of active cells. The conversion of ammonia to nitrate is brought about by two highly specialized groups of obligatory aerobic chemoautotrophic bacteria (Nitrosomonas and Nitrobacter). Nitrification occurs in two main sequential steps: Ammonia is enzymatically oxidized via nitrite to nitrate (ALEF, 1995a).

1. Ammonia oxidation:

$$
\mathrm{NH}_{4}^{+}+1.5 \mathrm{O}_{2} \stackrel{\text { Nitrosomonas }}{\longrightarrow} \mathrm{NO}_{2}^{-}+\mathrm{H}_{2} \mathrm{O}+2 \mathrm{H}^{+}\left(\mathrm{G}^{\circ}=-273.9 \mathrm{~kJ} \mathrm{~mol}^{-1}\right) .
$$

2. Nitrite oxidation:

$$
\mathrm{NO}_{2}^{-}+0.5 \mathrm{O}_{2} \stackrel{\text { Nitrobacter }}{\longrightarrow} \mathrm{NO}_{3}^{-} \quad\left(\mathrm{G}^{\circ}=-76.7 \mathrm{~kJ} \mathrm{~mol}^{-1}\right)
$$

The energy obtained from the oxidation of either $\mathrm{NH}_{4}{ }^{+}$or $\mathrm{NO}_{2}{ }^{-}$can be used for autotrophic $\mathrm{CO}_{2}$ fixation.

Since soil productivity depends on mineralization of SOM, studies on soil organic N mineralization and its controlling factors are important to evaluate sustainability of a system (GONZALES-PRIETO et al., 1996). However, a satisfactory method of predicting $\mathrm{N}$ mineralization rates is still not found. Several attempts have been made to estimate $\mathrm{N}$ mineralization and $\mathrm{N}$ fertilizer requirements using simulation models. In a validation study of 14 models describing $\mathrm{N}$ dynamics in the crop-soil-system, crop response to available soil mineral $\mathrm{N}$ was satisfactorily simulated, whereas the simulated dynamics of soil mineral $\mathrm{N}$ were inaccurate (DE WILLIGEN, 1991). This was mainly a result of inadequate understanding of SOM dynamics (GroOT and HoubA, 1995). GonZALES-PRIETO et al. (1996) suggested that the total $\mathrm{N}$ content might be a misleading parameter with respect to $\mathrm{N}$ mineralization and $\mathrm{N}$ availability because high total $\mathrm{N}$ contents do not necessarily supply high amounts of available N.

The progress in understanding of $\mathrm{N}$ cycling processes is still discussed contradictory in the literature. It has become apparent that results of $\mathrm{N}$ mineralization from different locations and climates do not necessarily fit well into existing general concepts (JARVIS, 1996). To make confident model predictions, a much better understanding of the transformation processes will be required. Further information is needed on key characteristics of soil biological activity, microbial biomass, and functional diversity in relation to $\mathrm{N}$ cycling processes (BURKET and DICK, 1998). 


\subsection{Nitrogen availability indices}

Better knowledge of the mechanisms and indicators of $\mathrm{N}$ mineralization in soils is essential to improve $\mathrm{N}$-use efficiency and reduce environmental impacts from agricultural activities (BURKET and DiCK, 1998). In general, $\mathrm{N}$ availability indices are chemical or biological soil tests to measure or estimate the amounts of available $\mathrm{N}$ released from soil under controlled conditions. The different methods of assessing $\mathrm{N}$ availability include aerobic and anaerobic incubation tests, extraction of soil inorganic $\mathrm{N}$, and plant $\mathrm{N}$ uptake of test plants in pot and field studies.

\subsubsection{Estimation of nitrogen mineralization by aerobic laboratory incubation}

The aerobic incubation method (KEENEY and BREMNER, 1966 as cited by KEENEY, 1982) modified by BECK (1983) is an estimation of net $\mathrm{N}$ mineralization potential. The method is based on the incubation of moist soil at $25^{\circ} \mathrm{C}$ followed by the determination of $\mathrm{NO}_{3}{ }^{-}$and $\mathrm{NH}_{4}{ }^{+}$. However, the assimilation of $\mathrm{NH}_{4}{ }^{+}$and $\mathrm{NO}_{3}{ }^{-}$by soil microorganisms interferes with the results.

Because of the substantial time investment for the aerobic incubation technique this method is used only when long-term $\mathrm{N}$ mineralization information is essential. For example, long-term incubation data provide a standard method of assessing the potential long-term N supplying capacities of soils (STANFORD, 1982). In addition, the long-term incubation technique is useful for evaluating the effects of past management practices or experimental treatments on $\mathrm{N}$-supplying capability. Long-term incubations are also frequently used in work to distinguish between ammonification and nitrification and moreover, to model soil $\mathrm{N}$ mineralization and characterize various components of the labile $\mathrm{N}$ pool in soils. According to KEENEY (1982) and RASMUSSEN et al. (1998) aerobic laboratory evaluations of $\mathrm{N}$ mineralization rates or $\mathrm{N}$ mineralization potential have proved to be more useful indexes in semi-arid cereal grain regions than in other cropping systems.

\subsubsection{Evaluation of ammonium-N production under waterlogged conditions}

This method has been suggested by KEENEY (1982) as a biological index of N availability. It is based on incubation of a soil-water mixture under waterlogged conditions in closed test tubes kept at $40{ }^{\circ} \mathrm{C}$ for 7 days. This method has several advantages that make it attractive when a rapid biological index is needed to provide an assessment of $\mathrm{N}$ availability. These advantages include its simplicity and ease of adoption to laboratory 
routine, a short incubation time (7 days), little or no influence of sample pretreatment on test results, elimination of concerns related to optimum water content and water loss during incubation, and minimal apparatus and reagent requirements (KEENEY, 1982). Although previous reviews reported satisfactory correspondence of results from this method with other indices (KEENEY, 1982; STANFORD, 1982; MEISINGER, 1984), several studies have found poor correlations between $\mathrm{NH}_{4}{ }^{+}$production under waterlogged conditions and field measurements of $\mathrm{N}$ availability (FOX \& PIEKIELEK, 1984; McCRACKEN et al., 1989; Hong et al., 1990). BoONE (1990) suggested that apparent differences between $\mathrm{N}$ availability measured via anaerobic incubation and field data are not contradictions but reflect differential $\mathrm{N}$ transformation pathways as measured by the methods. Specifically, field measurements represent the net effect of $\mathrm{N}$ mineralization and $\mathrm{N}$ immobilization under fluctuating but mainly aerobic conditions, whereas waterlogged incubation likely measures $\mathrm{N}$ mineralization from aerobic soil organisms suppressed by anaerobic conditions.

\subsection{Soil enzymes}

Soil enzymes have been given more importance over recent years in evaluating soil microbial activity and status (BURKET and DICK, 1998). The various biochemical soil nutrient cycling processes are mediated by soil enzymes as catalysts which are derived from microorganisms, plant roots, and soil animals (TABATABAI, 1982). Although some enzymes (e.g. dehydrogenase) are found in viable cells most soil enzymes can also exist as exoenzymes secreted by microorganisms or as enzymes originating from microbial debris and plant residue that are stabilized in complexes of clay minerals and humic colloids (DICK, 1992).

Enzymes in soil solution are easily inactivated by adsorption, denaturation or degradation (Perez-Mateos et al., 1991 as cited by Busto and Perez-Mateos, 1995). Soil enzymes are central to microbial activity and nutrient transformations (BURKET and DICK, 1998). However, it is difficult to extract enzymes from soils. Therefore, enzymes are studied indirectly by measuring the activity via assays. Because assays are done in vitro under controlled conditions (temperature, buffers, excess substrate, etc.) it is difficult to relate activities to those occurring in situ (DICK, 1992). Nevertheless, studying soil enzyme activity provides insight into biochemical processes in soils (FRANKENBERGER and DiCK, 1983). Moreover, enzyme activities have been shown to be responsive to environmental conditions and agricultural management (DICK, 1992; DICK, 1994). 
Measurements of specific enzyme activities may be useful to assess soil biological activity, which might be used as a sensitive biological index of soil quality (FRANKENBERGER and DICK, 1983; PERUCCI, 1992). These findings are supported by VISSER and PARKINSON (1992); JoRdAn et al. (1995); DiEKMANN (1997); BURKET and Dick (1998); TRASARCEPEDA et al. (1998); WICK et al. (1998) who considered soil enzyme activity to be a major factor contributing to soil quality and providing a means for assessing soil degradation.

\section{Acid and alkaline phosphomonoesterase}

Phosphatases (phosphomonoesterases) is a general term used to describe a broad group of enzymes that are involved in degradation of organic $\mathrm{P}$ compounds to orthophosphate and thus, making them available to both, microbes and plants. There are acid phosphatases with optimum activities at pH 6.0 - 6.6 and alkaline phosphatases with an optimal pH of 9.0 11.0 (TABATABAI and BREMNER, 1969). Both are orthophosphoric monoester phosphohydrolases catalyzing hydrolysis of ester bonds binding $\mathrm{P}$ to $\mathrm{C}$ in organic matter (DENG and Tabatabai, 1997). In soil P cycling, the hydrolysis of ester-bound $\mathrm{P}$ is the major process (TABATABAI, 1994). As a consequence inorganic $\mathrm{P}$ is released from organic sources of $\mathrm{P}$, such as leaf litter, dead roots and other organic debris in the soil.

Acid phosphatases are produced by plant roots, animal and microbial cells. On the other hand alkaline enzymes have been found only in microorganisms and animals (TABATABAI, 1994). The activities of phosphatases are considered especially useful indicators of both the positive and negative effects of soil management practices on soil quality (DICK, 1994; JORDAN et al., 1995). This was confirmed by DIEKMANN (1997) for acid phosphatase activity in eastern Amazonia and by WICK et al. (1998) for alkaline phosphatase activities in southern Nigeria.

\section{B-Glucosidase}

Glucosidases are often included in studies searching for sensitive biomarkers of soil degradation (GARCIA and HERNANDEZ, 1997; TRASAR-CEPEDA, et al. (1998) and soil quality (BURKET and DICK, 1998). They represent a group of enzymes that catalyze the hydrolysis of different disaccharides. The hydrolysis products are believed to be important energy sources for microorganisms such as bacteria in soils. The enzymes are widely distributed in nature and have been detected in soils, fungi, yeast, plants (TABATABAI, 1994) and animals (ALEF and NANNIPIERI, 1995). B-Glucosidase has optimum activities 
at pH 6.0 and is inactivated at temperatures of about $70^{\circ} \mathrm{C}$ (EIVAZI and TABATABAI 1988). As an extracellular enzyme B-glucosidase can be stabilized in the soil by soil-enzymehumus complexes. B-Glucosidase shows a significant positive correlation with SOM (EIVAZI and TABATABAI 1988) and B-glucosidase activity is considered to be the driving force in the decomposition of carbohydrates in soils (DENG and TABATABAI, 1996). According to ALEF and NANNIPIERI (1995) in the microbial degradation of cellulose to glucose, $\beta$-glucosidase is the rate limiting enzyme.

\section{Protease}

Proteins are the most abundant organic molecules in cells, constituting $50 \%$ or more of their dry weight (AlEF and NANNIPIERI, 1995a). Proteases catalyze the hydrolysis of proteins to polypeptides, and of oligopeptides to amino acids. This is an important step in the organic $\mathrm{N}$ cycle in soils before ammonification and nitrification proceed (LADD and BUTLER, 1972; HAYANO, 1993).

Nearly all microorganisms in soils are capable of protein degradation, which is generally linked to ammonium release (ALEF and NANNIPIERI, 1995a). In soil, proteases are present in living and active cells, in dead cells of microorganisms, plants and animals, as free enzymes, and adsorbed to organic, inorganic or organo-mineral particles (SARKAR et al., 1989). The optimal $\mathrm{pH}$ range is $6.8-8.8$, the temperature optimum is $55^{\circ} \mathrm{C}$ ( $\mathrm{LADD}, 1972$ ). At temperatures above $60^{\circ} \mathrm{C}$, the enzyme is denaturated (LADD and BUTLER, 1972).

In the field protease activity varied with season; it is not correlated with changes in microbial populations (LADD, 1978). Nevertheless, good correlations are mostly found between protease activity and microbial parameters estimated under laboratory conditions.

\subsection{Limitations of soil quality and microbial indicators}

Soil quality remains difficult to measure because soil and its functions are an ecologically complex phenomenon. It cannot be readily assessed directly by any single soil parameter, but instead must be evaluated as the function of several independent and/or correlated chemical, physical and biological properties that may exist at different spatial or temporal scales (PARR et al., 1992; SMITH et al., 1993a; DORAN and PARKIN, 1994). Moreover, appropriate microbial standard methodologies to evaluate past and present practices are lacking. However, there is growing evidence that soil biological properties are potential sensitive indicators of ecological stress on soil quality. 
It is therefore necessary to develop indices based on a combination of standard methodologies of several soil properties that provide a means for assessing

the degree of soil degradation,

- inappropriate land use, which can lead to soil degradation, and

- soil restoration measures.

Thus, sensitive indices and ranges or threshold levels for biomarkers indicating changes in soil quality have to be developed to identify endangered soils. Further, soil quality must be related to a particular location (regionalized). In order to define sustainability of a cropping system a high quality and undisturbed native reference soil is needed.

It is expected that in combination with chemical indicators and crop yields, soil microbiological data such as soil microbial biomass, soil enzyme activities and $\mathrm{N}$ mineralization parameter might help to explain soil nutrient dynamics and to identify the overall controlling factors that determine soil fertility and soil quality in savanna agroecosystems in West Africa. 


\section{$3 \quad$ Background Information to the Study Area}

\subsection{Location and population density}

The savanna zone of northern Ghana with a land area of $60960 \mathrm{~km}^{2}$ is between latitude $8^{\circ}-11^{\circ} \mathrm{N}$ and longitude $0^{\circ}-3^{\circ} \mathrm{W}$. It is bordered by Togo in the East, Burkina Faso in the North, and Ivory Coast in the West. In the South-East it borders the Volta Lake created by the Akosombo Dam in the South of Ghana (Annex, Map 1).

About $20 \%$ of the population of Ghana is living in northern Ghana. Since it comprises about $41 \%$ of the land area of Ghana it makes an important contribution to the food supply of the country (RUNGe-METZGER and DiEHL, 1993). The majority of the population (85\%) in northern Ghana is residing in the rural areas (HESSE, 1997). However, population density varies across the regions. With a high rate of population growth of about $3 \%$ per year the population density has been identified as one driving force in differentiating farming systems in northern Ghana (HESSE, 1997). The population pressure has reduced virgin lands, and traditional shifting cultivation with long fallow periods is now replaced by fallow periods of less than six years (RUNGE-METZGER and DiEHL, 1993). In the northeast overpopulation caused severe soil degradation and soil erosion (HESSE, 1997).

\subsection{Climate}

The climate of North Ghana is closely linked with the prevailing general air circulation affecting the West African sub-region. Two air masses of very contrasting characteristics determine the climate. These are the "harmattan" winds generally called the North East Trade Winds that usher in the dry season and the South Atlantic Maritime Air Mass referred to as the south west monsoon which brings moisture into the area during the rainy season. The convergence zone of the two air masses is called the inter-tropical convergence zone (ITCZ). The ITCZ can move in the short-term between an area of hundreds of kilometers. The weather at a given place and the rainfall in particular is therefore determined to a large extent by the movement and position of ITCZ belt. Long-term rainfall variation is high whereas temperature variation is very low. It is the moisture that imposes its seasonality on the cropping cycle of the area.

Agroecologically, the northern savanna zone of Ghana is generally divided into the Guinea Savanna and Sudan Savanna (Figure 1). The study area belongs to the Northern Region 
(NR), which falls almost entirely within the Guinea Savanna whereas the bulk of the Upper East Region (UER) and Upper West Region (UWR) belong to the Sudan Savanna. The main differences between the Sudan and Guinea savanna are the amount of rainfall and the length of the growing period. Both increase from North to South. The climate of the Guinea Savanna is semi-arid with annual monomodal rainfall pattern. The mean annual rainfall is about 1000 - $1100 \mathrm{~mm}$. (RUNGE-METZGER and DiEHL, 1993).

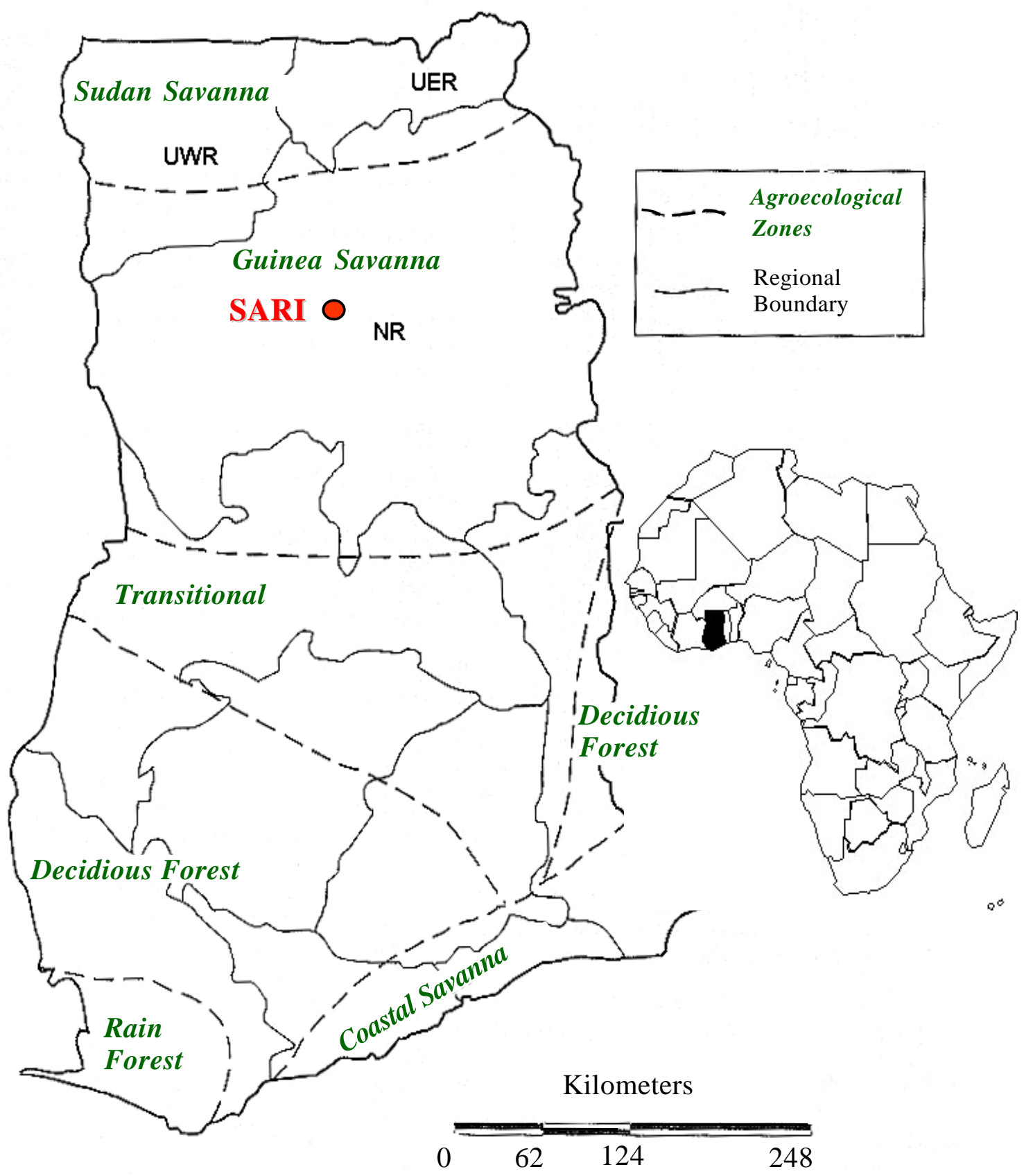

Figure 1: Map of Africa and agroecological zones in Ghana (modified from IFDC, 1994). 
The dry season is lasting for five to six months (November - April) and the rainy season for about six to seven months (May - October). Since the wet season may commence as early as by beginning of March or as late as the end of June the onset of the rains is unpredictable. However, about $90 \%$ of rains occur during June and September (Table 1). The first rain storms are often very heavy and only a small fraction infiltrates into the dry soil. Usually the major proportion of the early rains is lost due to surface run-off. Also during the humid phase, mainly in July short dry spells are common, which could result in severe yield losses. Occasionally sudden droughts at the beginning of the rainy season lead to complete crop failures. However, despite its adverse pattern rainfall normally exceeds potential evapotranspiration during July, August and September (KASEI, 1993).

Table 1: Summary of climatic data (Source: KASEI, 1993)

\begin{tabular}{|lcc|}
\hline & \multicolumn{2}{c|}{ Guinea Savanna (NR) } \\
Average of & $1936-1962$ & $1963-1989$ \\
\hline Total rain (mm) & 1111 & 1043 \\
Rain days (per year) & 92 & 75 \\
Rain in wet season (June to September) & 1000 & 679 \\
Rain days in wet season (June to September) & 78 & 44 \\
Coeff. of variation $(\%)$ & 15 & $15-20$ \\
\hline Potential evapotranspiration $(\mathrm{mm})$ & 1540 & 1776 \\
Temperature $\left({ }^{\circ} \mathrm{C}\right)$ & 27.8 & 28.3 \\
\hline
\end{tabular}

\subsection{Soils}

As depicted in (Figure 2) two major groups of parent materials can be distinguished. Namely the Voltaian Basin in the central, southern and the eastern part of the NR and the granitic formations beyond the escarpments in the north (UER and UWR) and in the western part of the NR. While the Voltaian Basin mainly consists of sandstones, shales, arkose and mudsones with low inherent content of nutrients, the granitic soils have naturally higher contents of nutrients. Furthermore the groundwater table is much higher in the granitic soils (HAUFFE, 1989).

Different hydrological conditions along the slopes lead to the development of different soils from the upland to the lowland. The study soils belong to the upland soils which are developed in situ from Voltaian sandstone and occupy $80 \%$ of the cultivated area. 


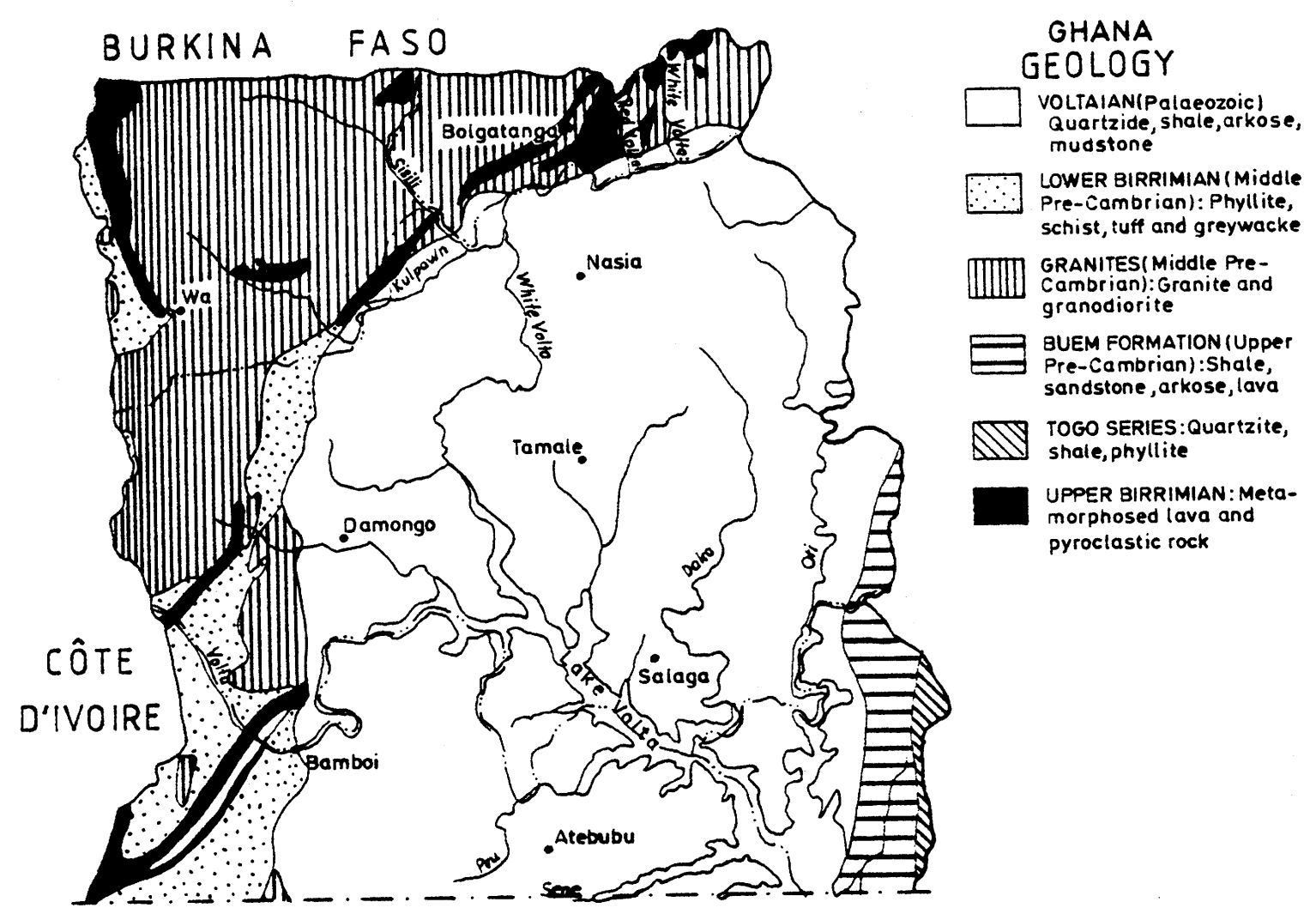

Figure 2: Geology of northern Ghana (Source: RUNGE-METZGER \& Diehl 1993).

According to the FAO-classification the soils belong to the group of Lixisols (FAO, 1988). The top soils mostly sandy and the gravel content increases with soil depth (HAUFFE, 1989). The soils are characterized by widespread lateritic concretions (OWUSU-BENNOAH et al., 1991). In the topsoil there are only a few aggregates existing and therefore storage of plant available water in the soils is not only limited by an unfavorable pore size distribution (sufficient for about 15 days under maize; HAUFFE, 1989), but also by low infiltration. Having a low aggregate stability they are extremely susceptible to surface sealing by rains and to soil erosion. However, during wet periods these soils have the advantage of a good drainage (HAUFFE, 1989).

\subsection{Agriculture in the Northern Savanna Zones}

The Northern sector of Ghana has been reported as an area of high agricultural potential. The principal constraints to increasing agriculture include declining soil fertility of the fragile soils, soil erosion, lack of credit programs and improved agronomic practices, and lack of water conservation techniques (RUDAT and QUARSHIE, 1993; ALBERT, 1996). 
The prevailing farming systems in northern Ghana can be described generally as subsistence farming systems with low or minimum external input. The average field size is about 1.1 ha in NR. (ALBERT, 1996). The traditional farmers have been cultivating these soils over the years without mineral fertilizers. They maintained soil productivity by prolonged fallow periods of more than 15 years followed by four-year cropping periods (OWUSU-BENNOAH et al., 1991). Increased population pressure has caused shortened fallow periods and this has intensified problems of soil fertility maintenance and erosion control. Today, in many areas, fallow as the traditional measure fails to maintain soil fertility and to control weed infestation.

The length of the fallow can be used as an indicator of land use intensity by calculating the R-value (RUTHENBERG, 1980). It is defined as the number of years of cultivation (C) multiplied by 100 and divided by the length of the cycle of land utilization. The length of the cycle is the sum of the number of years of arable farming plus the number of years of fallow (F). According to RUTHENBERG (1980) permanent farming is practiced when the R-value exceeds 66. For instance, in 1993 a mean R-value of 50 was found in the NR (AlberT, 1996). Runge-METZGER and DiEHL (1993) stated that the relatively high R-value in NR is an indication for intensive land use and the traditional shifting cultivation system is abandoned. Shifting cultivation is now replaced with fallow periods of less than five years. In densely populated areas arable land becomes even more scarce so that farmers have to reduce fallow periods to less than 2 years (ALBERT, 1996; HESSE 1997). According to the definition of RUTHENBERG (1980) in the UWR (Tumu) and in the western part of the NR (Bole/Sawla) some farming systems still represent the archaic shifting cultivation system, while other areas in the NR (Karaga, Bimbilla, Wantugu) and the study area (Cheshegu) are to be classified as semi-permanent bush-fallow systems (RUNGE-METZGER and Diehl, 1993). In the north-east areas of the NR (Nakpanduri, Navrongo and Binduri) permanent cropping systems are dominating.

RUTHENBERG (1980) suggested that tropical soils require 10 to 20 years fallow for regeneration. Thus, fallow periods of less than five years in the savanna region of Ghana are not sufficiently long permitting complete regeneration of the soil. Consequently, repeated cropping with traditionally long cultivation periods and short unfertilized grass fallows brings about long-term land degradation. Moreover, repeated cultivation not only leads to exhaustion of the soil nutrients but also favors erosion. 
Today, the northern regions of Ghana rank first in the production of the four major cereals (maize, rice, sorghum, millet) cultivated in the country (MOA, 1993). Maize is the most widely grown cereal in northern Ghana. The area under maize decreases with increasing population density while that under sorghum and millet increases (HESSE, 1997).

On the farm level in northern Ghana two types of fields, namely bush fields (lowland and upland) and compound fields can be distinguished. In general, fields close to the compound receive organic manure, fields at an intermediate distance are intercropped with legumes and occasionally receive mineral fertilizer, whereas far away bush fields are fallowed.

Per definition compound fields are located around the houses. Nutrients are recycled in form of faeces and urine as well as household wastes and ashes. Thus, compound farming can be characterized as a nutrient-concentrating system where nutrients are extracted from the larger bush fields and applied on the smaller compound field. It is mainly permanent cropping without fallow periods and is gaining increasing importance in areas with increasing population pressure. It can be stated that increasing intensification without mineral fertilizer input is only possible in permanent compound farming systems. They are usually planted with early maturing crops (early millet), vegetables, tobacco and spices. However, maize is more and more grown on compound fields in areas with sufficient rainfall.

Bush fields are located away from the homesteads. The distance from the compound to the bush farm varies strongly between 15 and 60 minutes foot walk (ALBERT, 1996). Some farmers are cultivating bush fields which are more than two hours away from the compound. Human labour is still the most important input in small scale agriculture in northern Ghana. Therefore, the distance from the compound to the field has a strong influence on the farming activities. If the field is far away, soil tillage, the application of fertilizer, manure or pesticides become more tedious or it is not practicable because all the inputs have to be carried on the head or transported by bicycle to the field. Intercropping of cereals and leguminous crops is the dominant cropping pattern in bush fields. Maize, sorghum, millet, groundnut, cowpea and yam are usually grown.

Cash crops such as cotton, cowpea, groundnut, and soybean are gaining more popularity among the rural farmers. However, cotton and soybean growing remains highly localized. Among the leguminous crops groundnuts are predominantly grown in the areas of medium population density. In other parts of northern Ghana cowpea is taking a greater share of cropped land. It is cropped as relay crop, intercrop and sole crop. Cotton is only grown as a sole crop in contract with cotton companies (RUNGE-METZGER and DIEHL, 1993). 


\section{$4 \quad$ Materials and Methods}

\subsection{Location and climate of the experimental sites}

The Savanna Agricultural Research Institute (SARI), formerly Nyankpala Agricultural Experiment Station (NAES), is located $16 \mathrm{~km}$ west of Tamale at $9^{\circ} 25^{\prime} \mathrm{N}$ and $1^{\circ} \mathrm{W}$ in the Guinea Savanna in the Northern Region of Ghana. The actual experimental sites were located in a neighboring village of SARI namely in Ceshegu in the Tolon-Kumbungu district (see Map 1, Annex).

All meteorological data were recorded at the standard meteorological station at SARI. Rain was measured daily $1 \mathrm{~m}$ above the ground with a rain-gauge at the field site. The mean annual rain, potential evaporation and temperatures in the study years (1993 - 1995) are given in Figure 3. Compared to the long-term mean $(1043 \mathrm{~mm})$ rains in the years 1993 with a total of $1037 \mathrm{~mm}$ and 1995 with $1021 \mathrm{~mm}$ were normal and well distributed during June to September. In 1994 annual rainfall with $1.212 \mathrm{~mm}$ was higher than the long-term mean. However, in 1994 between mid of July and mid of August 1994 there was a short dry spell in the area around SARI.

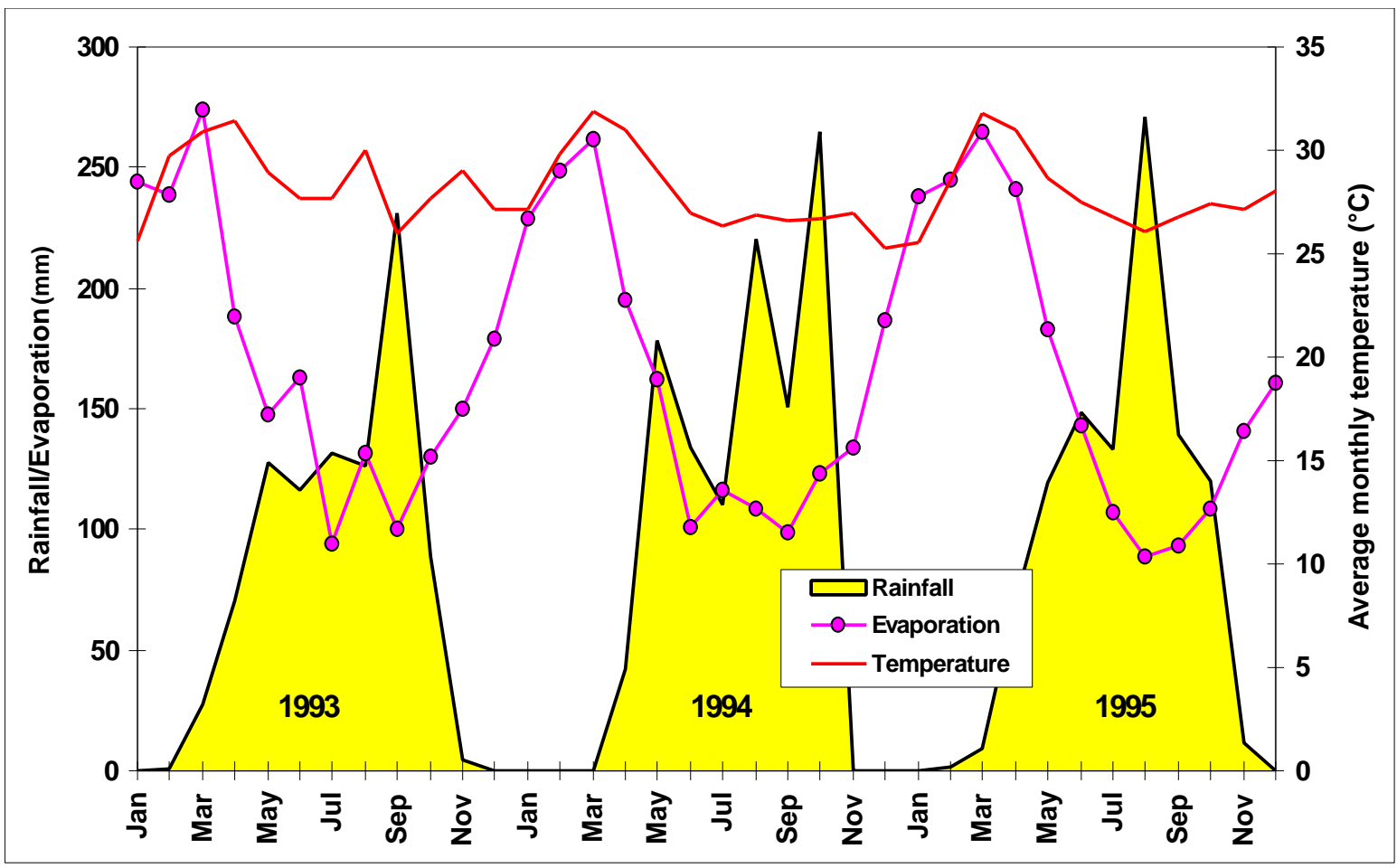

Figure 3: Rainfall, evaporation and temperature at SARI 1993 - 1995 (experimental years). 


\subsection{Selection of study sites and experimental design}

The main objective of the minus-one (missing-element) trials was to compare the productivity of the non-degraded site $(\mathrm{CH} 1)$ with the degraded site $(\mathrm{CH} 2)$. Maize (Zea mays L.) c.v. Abeleehi with 90 days growth duration was used as test crop in order to (1) check for nutrient deficiency as a reason for low maize yield and (2) to link nutrient availability with soil microbial parameters.

During the rainy seasons from 1993 - 1995 two identical minus-one trials were carried out on two different farmers fields near Cheshegu. The research approach was to select appropriate farmers' fields as experimental sites with contrasting degree of soil degradation due to different land use. The fertility status was estimated by the yield levels of the previous crops at the beginning of the experiment in June 1993. According to the farmers' classification, two bush fields were chosen as experimental sites. One was classified as fertile $(\mathrm{CH} 1)$ and the other one as non- fertile $(\mathrm{CH} 2)$. Thus, the two sites were rated as non-degraded $(\mathrm{CH} 1)$ and the degraded $(\mathrm{CH} 2)$. On both fields there was no fallow period during the past three years before the experiment. The crop and fertilizer history of the experimental sites is given in Table 2. The use of external inputs (e.g. fertilizers) during the previous years was low at both sites. The mineral fertilizer dose is unknown, however, the farmer from $\mathrm{CH} 2$ reported a slightly higher fertilizer application on the degraded $\mathrm{CH} 2$ site as compared to the non-degraded $\mathrm{CH} 1$ site.

Table 2: Land use history of experimental sites

\begin{tabular}{lcll}
\hline Site & Classification by the farmer & Year & Crop history \\
\hline CH 1 & fertile & 1989 & Okra (Abelmoschus esculentus) \\
(non-degraded) & 1990 & Maize (Zea mays L.) \\
& 1991 & Cowpea (Vigna unguiculata L.) \\
& 1992 & Maize (Zea mays L.) \\
& & \\
CH 2 & 1989 & Yam (Dioscorea alata) \\
(degraded) & 1990 & Maize/Sorghum/Groundnut (intercropping) \\
& & (Zea mays L., Sorghum bicolor, Arachis hypo- \\
& & gaea) \\
& 1991 & Groundnut (Arachis hypogaea) \\
& 1992 & Maize (Zea mays L.) \\
\hline
\end{tabular}


The experimental design was a single-factor trial with ten treatments repeated in five randomized complete blocks (Figure 4). The treatments in the first year (1993) are given in Table 3. The rates of nutrients applied with different treatments are shown in Table 4. In the complete fertilized treatment (All) the elements $\mathrm{N}, \mathrm{P}, \mathrm{K}, \mathrm{Ca}, \mathrm{Mg}, \mathrm{S}$, and Mo were applied. To detect the limiting nutrient, seven subtractive treatments $(3-9)$ where all nutrients were applied as in treatment 1 except one nutrient (-N, -P, $-\mathrm{K},-\mathrm{Ca},-\mathrm{Mg},-\mathrm{S},-\mathrm{Mo})$ were included. As additional treatment, cotton seed waste $\left(2 \mathrm{t} \mathrm{DM} \mathrm{ha}^{-1}\right)$ was applied as organic fertilizer (Table 5). To avoid Zn deficiency in $1993 \mathrm{Zn}$ was applied at a rate of $10 \mathrm{~kg} \mathrm{ha}^{-1}$ across all treatments

Table 3: Treatments of the minus-one field experiments in the first year (1993)

\begin{tabular}{crl}
\hline No. & Treatment & Nutrient application \\
\hline 1 & All & application of all seven nutrients: N, P, K, Ca, Mg, S, Mo \\
2 & All + org & $\begin{array}{l}\text { application of all nutrients } \\
\text { plus cotton seed waste as organic fertilizer) }\end{array}$ \\
3 & $-\mathrm{N}$ & all nutrients without $\mathrm{N}$ \\
4 & $-\mathrm{P}$ & all nutrients without $\mathrm{P}$ \\
5 & $-\mathrm{K}$ & all nutrients without $\mathrm{K}$ \\
6 & $-\mathrm{Ca}$ & all nutrients without Ca \\
7 & $-\mathrm{Mg}$ & all nutrients without $\mathrm{Mg}$ \\
8 & $-\mathrm{S}$ & all nutrients without $\mathrm{S}$ \\
9 & $-\mathrm{Mo}$ & all nutrients without $\mathrm{Mo}$ \\
10 & none & control = without any fertilization \\
\hline
\end{tabular}

Identical experiments were superimposed on the same fields of 1993. However, the treatment pattern in 1994 - 1995 were modified according to results of 1993 (Table 6). Due to lacking response the (-Ca) treatment was replaced by cotton seed waste (org) only at $2 \mathrm{t} \mathrm{DM} \mathrm{ha}^{-1}$. The aim was to evaluate the effect of cotton seed waste as a pure organic fertilizer and as additional control to treatment 10 (none). To check for possible $\mathrm{Zn}$ deficiency, $\mathrm{Zn}$ was applied in treatment $1-5,7$ and 8, whereas the former treatment 9 (-Mo) was also modified to the treatment without Mo and $\mathrm{Zn}(-\mathrm{Mo} / \mathrm{Zn})$. The rate of $\mathrm{Zn}$ was reduced from $10 \mathrm{~kg} \mathrm{ha}^{-1}$ to $5 \mathrm{~kg} \mathrm{ha}^{-1}$ (Table 6). 
Table 4: Nutrient rates applied with different treatments in June 1993:

\begin{tabular}{|c|c|c|}
\hline Nutrient & Amount & Application \\
\hline $\mathrm{Zn}$ & $10 \mathrm{~kg} \mathrm{ha}^{-1}$ & as Zinc chloride \\
\hline $\mathrm{N}$ & $100 \mathrm{~kg} \mathrm{ha}^{-1}$ & as Urea \\
\hline $\mathrm{P}$ & $60 \mathrm{~kg} \mathrm{ha}^{-1}$ & $\begin{array}{l}\text { as Triplesuperphosphate (TSP) or } \\
\text { as Diammoniumphosphate (DAP) (only treatment 6) }\end{array}$ \\
\hline $\mathrm{K}$ & $60 \mathrm{~kg}$ ha- 1 & $\begin{array}{l}\text { as Potassium sulphate or } \\
\text { as Potassium chloride (only treatment } 8 \text { ) }\end{array}$ \\
\hline $\mathrm{Ca}$ & $78 \mathrm{~kg}$ ha- 1 & $\begin{array}{l}\text { as Triplesuperphosphate (TSP) or } \\
\text { as Calcium chloride (only treatment } 4 \text { ) }\end{array}$ \\
\hline $\mathrm{Mg}$ & $20 \mathrm{~kg}$ ha- 1 & $\begin{array}{l}\text { as Magnesium chloride or } \\
\text { as Magnesium sulphate (only treatment 5) }\end{array}$ \\
\hline$S$ & $25 \mathrm{~kg}$ ha- 1 & $\begin{array}{l}\text { as Potassium sulphate or } \\
\text { as Magnesium sulphate }\end{array}$ \\
\hline Mo & $400 \mathrm{~g} \mathrm{ha}^{-1}$ & as Sodium molybdate \\
\hline
\end{tabular}

Table 5: Carbon and nutrients in cotton seed waste $\left(2 \mathrm{t} \mathrm{DM} \mathrm{ha}^{-1}\right)$

\begin{tabular}{|lcccccccccc|}
\hline Nutrients & $\mathrm{C}$ & $\mathrm{N}$ & $\mathrm{C} / \mathrm{N}$ & $\mathrm{P}$ & $\mathrm{K}$ & $\mathrm{Ca}$ & $\mathrm{Mg}$ & $\mathrm{Mn}$ & $\mathrm{Zn}$ & $\mathrm{S}$ \\
$\mathrm{kg} \mathrm{ha}^{-1}$ & 936 & 33 & 41 & 6 & 30 & 10 & 4 & 0.05 & 0.03 & 1 \\
$\mathrm{sd}$ & 23 & 8 & 3 & 1 & 13 & 3 & 1 & 0.001 & 0.003 & 0.07 \\
\hline
\end{tabular}

sd = standard deviation of the means 1993, 1994 and 1995.

\subsection{Agronomic measures}

The time schedule of different agronomic measures in the minus-one trials is shown for 1993, 1994, 1995 in Table 40 - 43 of the Annex.

During the dry season 1992/93 the experimental sites were burned by the farmers. In June 1993 the land was cleared by hand and ploughed with bullocks by the farmers. In 1994 and 1995 pre-sowing soil preparation was done by handhoe. Before sowing the maize the organic fertilizer was broadcast and incorporated into the soil by using handhoes. Maize was sown by hand (three seeds per hole) at the end of June each year. Spacing was 30 x $90 \mathrm{~cm}$ with 47619 plants per ha (see Figure 4). TSP was applied in bands close to the maize rows at sowing. 
Table 6: Modified treatments of the minus-one field experiments in 1994 and 1995.

\begin{tabular}{rrl}
\hline No. & Treatment & Nutrient application \\
\hline 1 & All & $\begin{array}{l}\text { application of all eight nutrients: N, P, K, Ca, Mg, S, Mo, Zn } \\
\text { application of all nutrients } \\
\text { plus cotton seed waste as organic fertilizer) }\end{array}$ \\
& All + org & all nutrients without $\mathrm{N}$ \\
3 & $-\mathrm{N}$ & all nutrients without $\mathrm{P}$ \\
4 & $-\mathrm{P}$ & all nutrients without $\mathrm{K}$ \\
5 & $-\mathrm{K}$ & only cotton seed waste as organic fertilizer \\
6 & org & all nutrients without Mg \\
7 & $-\mathrm{Mg}$ & all nutrients without $\mathrm{S}$ \\
8 & $-\mathrm{S}$ & all nutrients without Mo and without $\mathrm{Zn}$ \\
9 & $-\mathrm{Mo} /-\mathrm{Zn}$ & control = without any fertilization \\
10 & none &
\end{tabular}

Five to six days after sowing more than $75 \%$ of the plants had emerged. Ten days after sowing the remaining of the different fertilizers were applied and incorporated by handhoes. Nitrogen was applied in two splits. The first rate (1/3) was applied at ten days after planting and the second (2/3) after thinning maize plants to one plant per hill between four and five weeks after planting. The maize plants which were removed by thinning remained on the soil surface of each plot and were worked into the soil during the next weeding.

In 1993 pesticides were not applied. In 1994 a severe army worm infestation was successfully controlled by sequential spraying of Basudan" $(2 \mathrm{x})$ and Dursban" $(1 \mathrm{x})$. At the end of the season 1994 thrips on grains were controlled by a single Karate" ultra low volume application (ULV). In 1995 army worms were controlled by using "Karate" (ULV) once. 


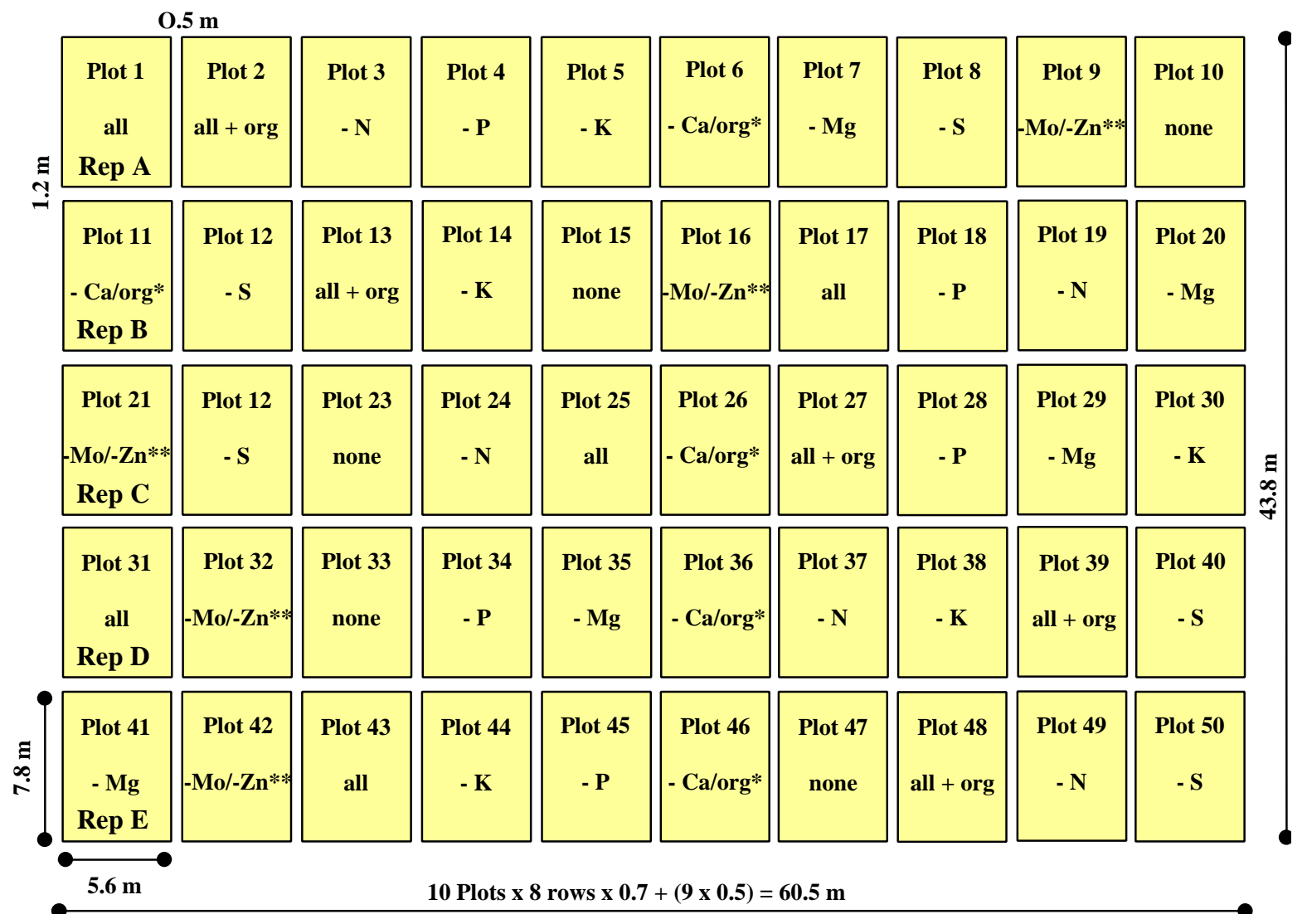

Figure 4: Field layout of minus-one field experiments from 1993 - 1995.

*treatment (-Ca) in 1993 was changed in 1994/95 to only" organic fertilizer (org)

**treatment (-Mo) in 1993 was changed in 1994/95 to "-Mo and -Zn" (-Mo/-Zn)

Distance between the rows: $0.7 \mathrm{~m}$, within the row: $0.3 \mathrm{~m}$, area per plant: $0.21 \mathrm{~m}^{2}$

Plant population: 47619 plants ha ${ }^{-1}$, harvest area: $19.32 \mathrm{~m}^{2}$

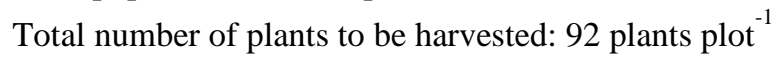




\subsection{Plant analysis}

\subsubsection{Plant sampling and processing}

Fresh weights of plant material were recorded either in the field or after transport of sub-samples to the laboratory. Dry weights were determined after oven-drying at $65{ }^{\circ} \mathrm{C}$ to constant weight. The dried sub-samples were ground and stored in plastic bags.

\section{Maize}

Final harvest was at 90 days after planting. Two border rows of each plot were excluded and the net harvested area was $19.32 \mathrm{~m}^{2}$ with 92 plants per plot (Figure 4) The maize plant was split up in two fractions: (1) stalks (leaves, stem, tassel, husks) and (2) cobs with grain. From each plot maize stalks from the remaining four center rows were cut down at the soil surface and maize cobs without husks were picked. Fresh weights of maize cobs and maize stalks were determined in the field with a field scale. Dry matter content of maize cobs and stalks was estimated from a randomly selected sub-sample of ten maize plants (cobs and stalks). The cobs were air-dried in the sun and shelled. Maize grain yield was estimated from the shelling percentage and dry matter yield of the cobs.

\section{Spontaneous bush fallow vegetation (natural regrowth)}

Sampling was done at the beginning of the third season in June 1995. The above ground plant biomass was determined by harvesting sub-samples from $1 \mathrm{~m}^{2}$ in each plot. Fresh and dry weight as well as the nutrient content was determined at the laboratory.

\subsubsection{Plant nutrient analysis}

Plant nutrient analysis was done for fallow vegetation at the beginning of the third season in June 1995 and for maize at the end of the third season in October 1995.

The plant material was ground before taking out sub-samples for nutrient analysis $(\mathrm{N}, \mathrm{P}, \mathrm{K}$, $\mathrm{Ca}, \mathrm{Mg}, \mathrm{Mn}$ and $\mathrm{Zn}$ ) using the standard methods of IITA (1979). Plant N was determined with the micro-Kjeldahl method. For $\mathrm{P}, \mathrm{K}, \mathrm{Ca}, \mathrm{Mg}, \mathrm{Mn}$, and $\mathrm{Zn}$ concentrations the plant material was digested with perchloric acid. The $\mathrm{P}$ content of the digest was analyzed colorimetrically by the Vanado-Molybdate method. $\mathrm{Ca}, \mathrm{Mg}, \mathrm{Mn}$ and $\mathrm{Zn}$ were determined with atomic absorption spectrometry, $\mathrm{K}$ by flame photometry. 


\subsection{Sampling, processing and analysis of soil}

The time schedule is presented in Table 43 of the Annex. Bulked soil samples from the upper $30 \mathrm{~cm}$ were collected randomly from the central portion of each plot. Twenty-five borings per plot were taken with a Pürkhauer soil auger. The bulked soil sample was mixed thoroughly in a bucket and five sub-samples were filled into plastic bags for microbiological and physical/chemical analysis. The sub-samples for microbial analysis were transported in cool boxes to the laboratory. Until analysis, the field moist soil samples were stored unsieved in plastic bags in a deep freezer at $-20^{\circ} \mathrm{C}$. Before sieving the SOIL samples were thawed at $4^{\circ} \mathrm{C}$ in a refrigerator. After sieving $(2 \mathrm{~mm})$ the samples were stored at $4{ }^{\circ} \mathrm{C}$ for one week until analysis. For physical and chemical analysis the soil was air dried, sieved $(2 \mathrm{~mm})$ and the refuse recorded. The fine soil was stored in plastic bags.

The methods used for soil analysis are given in Table 44 (Annex).

\subsubsection{Soil mineral $\mathbf{N}$}

Additional to the $0-30 \mathrm{~cm}$ depth as described above, composite soil samples were taken from depths of $30-60$ and $60-90 \mathrm{~cm}$ at 3 weeks intervals during the growth period in the third season. To reduce work load, samples were taken from a subset of the minus-one trials (treatment 1 (All), 2 (All org), 3 (-N), 6 (org), and 10 (none)) from three replicates.

After transport of the samples to the laboratory in cool boxes they were sieved $(2 \mathrm{~mm})$ and soil moisture content was determined. If not used for immediate analysis, the samples for mineral $\mathrm{N}$ analysis were either stored in the refrigerator or deep frozen in sealed polyethylene bags at a temperature of $-20{ }^{\circ} \mathrm{C}$ until analysis. Before analysis the soil samples were thawed slowly and stored in a refrigerator at $4{ }^{\circ} \mathrm{C}$. Soil samples were extracted with $2 \mathrm{M} \mathrm{KCL}$ and analyzed for ammonium and nitrate concentration. Ammonium-N was determined colorimetrically (KANDELER and GERBER, 1988). Nitrate-N was determined spectrometrically (SCHARPF and WEHRMANN, 1976) at $210 \mathrm{~nm}$. 


\subsubsection{Aerobic incubation method}

Estimation of soil $\mathrm{N}$ mineralization by aerobic incubation was done according to KEENEY and BREMNER (1966), as modified by BECK (1983). Fresh soil samples were incubated at $25{ }^{\circ} \mathrm{C}$ and the mineral $\mathrm{N}$ content $\left(\mathrm{N}_{\min }-\mathrm{N}=\mathrm{NO}_{3}-\mathrm{N}+\mathrm{NH}_{4}-\mathrm{N}\right)$ was measured at $0,1,3,6,9$, 12 weeks after start of incubation. To calculate net ammonifcation, net nitrification and net mineralization, initial $\mathrm{NH}_{4}-\mathrm{N}, \mathrm{NO}_{3}-\mathrm{N}$, and $\mathrm{N}_{\text {min }}-\mathrm{N}$ concentrations, from non-incubated samples (day 0), were subtracted from $\mathrm{NH}_{4}-\mathrm{N}, \mathrm{NO}_{3}-\mathrm{N}$, and $\mathrm{N}_{\min }-\mathrm{N}$ concentrations after 1 , $3,6,9,12$ weeks, respectively. $\mathrm{NH}_{4}-\mathrm{N}$ was determined colorimetrically according to KANDELER and GERBER (1988) and $\mathrm{NO}_{3}-\mathrm{N}$ according to SCHARPF and WEHRMANN (1976). Sampling dates were at maize planting in June 1995, in mid of August 1995, shortly after the first $\mathrm{N}$ fertilizer rate was given. Soil samples were taken from a subset including the treatments (All), (org) and the control plots from three replicates.

\subsubsection{Anaerobic incubation method}

The evaluation of $\mathrm{NH}_{4}-\mathrm{N}$ production under waterlogged conditions was determined according to KEENEY (1982). Field moist soil samples are incubated under waterlogged conditions at $40{ }^{\circ} \mathrm{C}$ for 7 days. $\mathrm{NH}_{4}-\mathrm{N}$ in soil extracts (KCL) was determined colorimetrically (KANDELER and GERBER, 1988). Mineralizable $\mathrm{N}$ was calculated as the difference between the initial and final measurement. Soil samples from the top soil $(0-30 \mathrm{~cm})$ were taken twice a year. The first sampling was at the beginning (before planting of maize), the second at the end of each season (harvest of maize). In the third year (1995), additional soil samples were taken from the soil profile at 0 - 30, 30 - 60 and 60 - $90 \mathrm{~cm}$ soil depth. The first sampling date was at maize planting in June, the second in mid of August, shortly after the first $\mathrm{N}$ fertilizer rate was applied. Soil samples were taken only from the treatments (All), (All org), (-N), (org) and from the control plots with five replicates.

\subsubsection{Soil microbial biomass}

Soil microbial biomass was determined using the chloroform-fumigation-extraction method according to AMATO and LADD (1988) as cited by JOERGENSEN (1995). After extraction with $2 \mathrm{M} \mathrm{K}_{2} \mathrm{SO}_{4}$ microbial $\mathrm{C}$ was estimated by the modified ninhydrin-N method according to JOERGENSEN and BROOKES (1990) as the difference between ninhydrin-N extracted from the fumigated and non-fumigated soil samples, multiplied by 20.6. 


\subsubsection{Soil enzyme analysis}

\subsubsection{Acid and alkaline phosphatase activity}

Acid and alkaline phosphatase activity [Enzyme Commission Number: 3.1.3.1 and 3.1.3.2; 1992] was determined according to TABATABAI and BREMNER (1969) and EIVAZI and TABATABAi (1977) as cited by SCHINNER et al. (1991). The release of p-nitrophenol from a p-nitrophenylphosphate solution (disodium-p-nitrophenylphosphate hexahydrate), added to the soil, during incubation for one hour at $37^{\circ} \mathrm{C}$ was determined colorimetrically at $400 \mathrm{~nm}$ upon one hour of incubation. Results of phosphatase activity were averages of two analytical replicates and expressed as $\mu \mathrm{g}$ p-nitrophenol released during one hour by one g oven-dry $\left(105^{\circ} \mathrm{C}\right)$ soil $\left(\mu \mathrm{g}\right.$ p-nitrophenol $\left.\mathrm{g} \mathrm{soil}^{-1} \mathrm{~h}^{-1}\right)$.

\subsubsection{B-Glucosidase activity}

ß-Glucosidase activity [ß-Glucosidase, Enzyme Commission Number: 3.2.1.21; 1992] was determined colorimetrically at $400 \mathrm{~nm}$ by release of p-nitrophenol from a p-nitrophenyl phosphate solution (p-nitrophenyl-ß-D-glucoside solution) after one hour of incubation at $37^{\circ} \mathrm{C}$ (EIVAZI and TABATABAI, 1988 as cited by ALEF et al., 1991). Results were averages of two analytical replicates and expressed as $\mu \mathrm{g}$ p-nitrophenol released during one hour by one g oven-dry $\left(105^{\circ} \mathrm{C}\right)$ soil $\left(\mu \mathrm{g}\right.$ p-nitrophenol g soil $\left.{ }^{-1} \mathrm{~h}^{-1}\right)$.

\subsubsection{Protease activity}

Protease activity [Protease, Enzyme Commission Number: 3.4; 1992] was determined according to LADD and BUTLER (1972) as cited by ALEF et al. (1991). Tyrosine released from submitted buffered sodium caseinate solution $(\mathrm{pH}$ 8.1) after incubation for two hours at $50{ }^{\circ} \mathrm{C}$ was determined colorimetrically at $700 \mathrm{~nm}$. Results of protease activity are means of two analytical replicates and are expressed as $\mu \mathrm{g}$ tyrosine released during two hours per $1 \mathrm{~g}$ oven-dry soil ( $\mu \mathrm{g}$ tyrosine $\mathrm{g}$ soil $\left.^{-1} 2 \mathrm{~h}^{-1}\right)$. 


\subsection{Statistics}

One-way ANOVA with treatments as levels was calculated on plant and soil parameters using the General Linear Model procedure of the software SySTAT (1992). Plant and soil measurements across time and soil analysis across soil depth were evaluated seperately. If the overall F-test was significant, differences of treatment means were tested by LSD-test at $p \leq 0.05$. Differences between locations were tested by computing a two-way ANOVA. To test on short-term effects across three cropping seasons a two-way ANOVA was computed for each single field using treatment and year as factors on data from 1993 to 1995. The significance is indicated as $* * *$ for $p \leq 0.001$, as $* *$ for $p \leq 0.01$ and as $*$ for $p \leq$ 0.05 and in some cases with ${ }^{+}$at $p \leq 0.1$. No significant effects are marked as ns for $p>0.1$. Pearson's correlation coefficient (r) was used to describe a simple linear regression between two variables using the Linear Regression Module of SYSTAT (1992).

\section{Curve fitting of aerobic $\mathbf{N}$ mineralization}

Cumulative mineral $\mathrm{N}\left(\mu \mathrm{g} \mathrm{N} \mathrm{g}{ }^{-1}\right.$ soil) from the aerobic incubation procedure ( 0 - 84 days) was fitted to the first-order model $\mathrm{N}_{\mathrm{t}}=\mathrm{N}_{0}\left(1-\mathrm{e}^{-\mathrm{kt}}\right)$ by the non-linear least squares procedure of SYSTAT. $\mathrm{N}_{0}$ is defined as the potentially mineralizable $\mathrm{N}_{0}$ and $\mathrm{k}$ as the mineralization rate constant. $\mathrm{N}_{0}$ and $\mathrm{k}$ were estimated separately for each treatment at each single field and sampling date. The significance of differences was assessed by using the asymptotic standard errors (A. S. E.). If the parameters $\mathrm{N}_{0}$ and $\mathrm{k}$ could not be estimated by simultaneous estimation, the sequential estimation with the Marquard iterative method of the software MODEL MAKER (Version 2.0, 1995) was used. Using this program k could be defined as a fixed parameter and $\mathrm{N}_{0}$ was estimated. This approach to estimate $\mathrm{N}_{0}$ was possible due to the fact that $\mathrm{k}$ did not show significant differences for the treatments. The results obtained show that the model could be successfully used to describe a pool of readily mineralizable $\mathrm{N}$ at the two examined sites.

The model gave $\mathrm{N}_{0}$ values higher than the measured cumulative mineral $\mathrm{N}$. In this concept, $\mathrm{N}_{0}$ is supposed to be the upper limit of potentially mineralizable $\mathrm{N}$, and therefore it should be greater than the observed cumulative mineral $\mathrm{N}$ at $\mathrm{t}=84$. Thus, the model was probably giving an accurate estimation of the labile $\mathrm{N}$ pool in each of the two soils. 


\section{Multivariate analysis}

Principal components analysis (PCA) was used to analyze soil variables of different sites. PCA is intended to reduce the number of variables to a smaller number of underlying factors or principal components (PC), which are linear combinations of the original variables (BACKHAUS, 1996). The factors contain most of the information of the data set and were interpreted according to its pattern of variables. The number of factors considered was assessed according to the Kaiser criterion (eigenvalue >1). The varimax rotation was used to achieve a simple structure among component loadings and factors. For interpretation of the factors only component loadings > $0.6 \mid$ were considered.

Factor or component scores were computed for single plots to evaluate the variability of the plots in each single field, distinguish between treatments and to show the differences between the two locations. Factor scores were displayed in a coordinate system to visualize how the original data set relates to the first, second and third PC. Plots with negative factor scores rated below average with respect to a PC, whereas zero and positive factor scores rated at average or above average. 


\section{$5 \quad$ Results and Discussion}

\subsection{Characterization of the experimental sites}

\subsubsection{Initial soil characteristics in June 1993}

Both sites are characterized by a sandy top soil (Table 7). Only clay and gravel content differed significantly. The gravel content increased with soil depth. Bulk density, aggregate stability, and moisture holding capacity are relatively low. The study soils were moderately acid. Base saturation was high (> 75) with $\mathrm{Ca}$ and $\mathrm{Mg}$ as dominant exchangeable cations. The high base saturation of these highly weathered soils can be explained by deposition and replenishment of bases with ash from annual burns and from Harmattan dust inputs (ABEKOE and TIESSEN, 1998).

Very low soil cation exchange capacity (CEC) indicates mainly kaolinitic clay minerals in the soil with corresponding low nutrient- and water-retention capacity of the soil. Soil exchangeable cations ( $\mathrm{K}, \mathrm{Ca}, \mathrm{Mg}, \mathrm{Mn}$ and $\mathrm{Zn}$ ) at $\mathrm{CH} 2$ ranged below the critical level (LANDON, 1991). The values at $\mathrm{CH} 1$ are rated at slightly above or reaching the critical range. Extractable sulfate-S was below the critical range in both soils (LANDON, 1991).

At both sites soil organic $\mathrm{C}$ and total $\mathrm{N}$ content were very low (organic $\mathrm{C}<2 \%$ and for total $\mathrm{N}<0.1$ as $\%$ of soil by weight). Both study sites have to be rated as $\mathrm{P}$ deficient sites (LANDON, 1991). ABEKOE and TIESSEN (1998) reported that soils from semiarid northern Ghana are inherently low in plant available P. In these soils P sorption and low mobility of $\mathrm{P}$ at field capacity results in low $\mathrm{P}$ supplying ability which limits agronomic effectiveness of P fertilizers. Soil organic P content was significantly higher at $\mathrm{CH} 1$ than at $\mathrm{CH} 2$. Ratings for organic $\mathrm{P}$ were not found in the literature, however, organic $\mathrm{P}$ represents an active reservoir of $\mathrm{P}$ and has been used as an indicator of the P-status and fertility of soils (TIESSEN et al., 1991).

\section{Mineral $\mathrm{N}$ and potential $\mathrm{N}$ mineralization after anaerobic incubation}

The values of soil $\mathrm{NH}_{4}-\mathrm{N}, \mathrm{NO}_{3}-\mathrm{N}$, and $\mathrm{N}_{\min }-\mathrm{N}$ content were 25,12 and $37 \mathrm{~kg} \mathrm{~N}^{-1}$ at $\mathrm{CH} 1$ and 3, 20 and $24 \mathrm{~kg} \mathrm{~N}^{-1}$ at $\mathrm{CH} 2$, respectively. Potential $\mathrm{N}$ mineralization values after anaerobic incubation (pot- $\mathrm{N}_{\min }$ ) were $-22 \mathrm{~kg} \mathrm{~N} \mathrm{ha}^{-1}$ at $\mathrm{CH} 1$ and $6 \mathrm{~kg} \mathrm{~N} \mathrm{ha}^{-1}$ at $\mathrm{CH}$ 2. The negative value obtained at the $\mathrm{CH} 1$ site indicates $\mathrm{N}$ immobilization by soil microorganisms in the $\mathrm{CH} 1$ soil (Table 7). 
Table 7: Unequal T-test on initial physical and chemical characteristics in the topsoil $(0-30 \mathrm{~cm})$ from neighboring minus-one trials $(\mathrm{CH} \mathrm{1,} \mathrm{CH} 2)$ at the beginning of the experiments in June 1993.

\begin{tabular}{|c|c|c|c|}
\hline & $\mathrm{CH} 1$ & $\mathrm{CH} 2$ & $t$-test \\
\hline \multicolumn{4}{|l|}{ Physical properties } \\
\hline Clay $(\%)^{\mathrm{a}}$ & 8 & 5 & $* *$ \\
\hline Silt $(\%)^{\mathrm{a}}$ & 24 & 22 & $\mathrm{~ns}$ \\
\hline Sand $(\%)^{\mathrm{a}}$ & 68 & 73 & + \\
\hline Gravel $(\%)^{\mathrm{b}}$ & 36 & 20 & $* * *$ \\
\hline at $30-60 \mathrm{~cm}$ soil depth & 86 & 53 & $* * *$ \\
\hline at $60-90 \mathrm{~cm}$ soil depth & 82 & 70 & $* * *$ \\
\hline Bulk density $\left(\mathrm{Mg} \mathrm{m}^{-3}\right)$ & 1.4 & 1.4 & $\mathrm{~ns}$ \\
\hline \multicolumn{4}{|l|}{ Chemical properties } \\
\hline $\mathrm{pH}\left(\mathrm{CaCl}_{2}\right)$ & 6.1 & 5.7 & $* * *$ \\
\hline Organic C (\%) & 0.9 & 0.5 & $* * *$ \\
\hline Total N (\%) & 0.07 & 0.05 & $* * *$ \\
\hline C-N-ratio (\%) & 13.3 & 10.5 & $* * *$ \\
\hline Available P (ppm) (Bray-I) & 8 & 3 & $* * *$ \\
\hline Organic P (ppm) & 162 & 84 & $* * *$ \\
\hline Extractable sulfate-S (ppm) & 1.8 & 1.4 & $* * *$ \\
\hline Cation exchange capacity $\left(\mathrm{cmol}^{+} \mathrm{kg}^{-1}\right)$ & 6.7 & 3.5 & $* * *$ \\
\hline Base saturation (\%) & 80 & 81 & $\mathrm{~ns}$ \\
\hline Exchangeable $\mathrm{K}\left(\mathrm{cmol}^{+} \mathrm{kg}^{-1}\right)$ & 0.2 & 0.1 & $* * *$ \\
\hline Exchangeable $\mathrm{Ca}\left(\mathrm{cmol}^{+} \mathrm{kg}^{-1}\right)$ & 4.3 & 2.1 & $* * *$ \\
\hline Exchangeable $\mathrm{Mg}\left(\mathrm{cmol}^{+} \mathrm{kg}^{-1}\right)$ & 1.1 & 0.5 & $* * *$ \\
\hline Exchangeable Mn (ppm) & 11.1 & 21.3 & $* * *$ \\
\hline Exchangeable Zn (ppm) & 1.2 & 0.4 & $* * *$ \\
\hline \multicolumn{4}{|l|}{ Mineral $N$ content and $N$ mineralization } \\
\hline $\mathrm{NH}_{4}-\mathrm{N}\left(\mathrm{kg} \mathrm{ha}^{-1}\right)$ & 25 & 4 & $* * *$ \\
\hline $\mathrm{NO}_{3}-\mathrm{N}\left(\mathrm{kg} \mathrm{ha}^{-1}\right)$ & 12 & 20 & $* *$ \\
\hline $\mathrm{N}_{\min }-\mathrm{N}\left(\mathrm{kg} \mathrm{ha}^{-1}\right)$ & 37 & 24 & $* * *$ \\
\hline pot- $\mathrm{N}_{\min }\left(\mathrm{kg} \mathrm{ha}^{-1}\right)^{\mathrm{c}}$ & -22 & 6 & $* * *$ \\
\hline
\end{tabular}

${ }^{\mathrm{a}} \%$ of fine soil, ${ }^{\mathrm{b}} \%$ of total soil,

${ }^{\mathrm{c}} \mathrm{NH}_{4}-\mathrm{N}$ mineralization after anaerobic incubation (biological $\mathrm{N}$ availability index) 


\section{Soil microbiological characteristics in June 1993}

Soil microbial biomass $\mathrm{C}$ content $\left(\mathrm{C}_{\text {mic }}\right)$ was significantly higher at $\mathrm{CH} 1$ than at $\mathrm{CH} 2$ (Table 8$)$. The ratio of soil microbial biomass $\mathrm{C}$ to total organic $\mathrm{C}\left(\mathrm{C}_{\text {mic }}-\mathrm{C}_{\text {org }}\right.$-ratio) was not significantly different. Soil acid and alkaline phosphatase activity, B-glucosidase activity and protease activity were significantly lower at the less fertile $\mathrm{CH} 2$ site. These results indicate a much lower biological activity in the $\mathrm{CH} 2$ field.

Table 8: Initial soil microbial characteristics of the topsoil $(0-30 \mathrm{~cm})$ from minus-one trials $(\mathrm{CH} \mathrm{1,} \mathrm{CH} \mathrm{2)} \mathrm{at} \mathrm{the} \mathrm{beginning} \mathrm{of} \mathrm{the} \mathrm{experiments} \mathrm{in} \mathrm{June} 1993$.

\begin{tabular}{|c|c|c|c|}
\hline & $\mathrm{CH} 1$ & $\mathrm{CH} 2$ & $t$-test \\
\hline \multicolumn{4}{|l|}{ Microbial properties } \\
\hline \multirow{2}{*}{$\begin{array}{r}\text { Microbial biomass carbon }\left(\mathrm{C}_{\mathrm{mic}}\right) \text { in } \mu \mathrm{g} \mathrm{g}^{-1} \\
\text { in } \mathrm{kg} \mathrm{ha}^{-1}\end{array}$} & 58 & 40 & $* * *$ \\
\hline & 241 & 168 & \\
\hline $\mathrm{C}_{\text {mic }}-\mathrm{C}_{\text {org }}$-ratio (\%) & 0.7 & 0.8 & ns \\
\hline $\begin{array}{l}\text { Acid phosphatase activity } \\
\left(\mu \mathrm{g} \text { p-nitrophenol } \mathrm{g}^{-1} \mathrm{~h}^{-1}\right)\end{array}$ & 214 & 137 & $* * *$ \\
\hline $\begin{array}{l}\text { Alkaline phosphatase activity } \\
\left(\mu \mathrm{g} \text { p-nitrophenol } \mathrm{g}^{-1} \mathrm{~h}^{-1}\right)\end{array}$ & 115 & 47 & $* * *$ \\
\hline $\begin{array}{l}\text { B-Glucosidase activity } \\
\left(\mu \mathrm{g} \text { p-nitrophenol } \mathrm{g}^{-1} \mathrm{~h}^{-1}\right)\end{array}$ & 28 & 11 & $* * *$ \\
\hline Protease activity $\left(\mu \mathrm{g}\right.$ tyrosin $\left.\mathrm{g}^{-1} 2 \mathrm{~h}^{-1}\right)$ & 65 & 34 & $* * *$ \\
\hline
\end{tabular}

\section{Initial soil fertility status of the study sites}

Soil parameters indicating initial soil fertility status differed substantially across the two neighboring sites at the beginning of the experiments in June 1993 (Table 7, Table 8). Apart from base saturation which did not differ between the fields, differences between the two sites occurred for all determined chemical soil properties as well as for mineral $\mathrm{N}$ $\left(\mathrm{NH}_{4}-\mathrm{N}, \mathrm{NO}_{3}-\mathrm{N}, \mathrm{N}_{\min }-\mathrm{N}\right.$ ), potential $\mathrm{N}$ mineralization (pot- $\mathrm{N}_{\min }$ ), soil microbial biomass $\left(\mathrm{C}_{\mathrm{mic}}\right)$, and soil enzyme activities. 
All observed soil property levels were significantly higher at the $\mathrm{CH} 1$ site. However, $\mathrm{NO}_{3}$ $\mathrm{N}$ content in soil was higher at $\mathrm{CH} 2$. Potential $\mathrm{N}$ mineralization after anaerobic incubation was negative at $\mathrm{CH}$ 1, indicating microbial $\mathrm{N}$ immobilization at this site. $\mathrm{N}$ immobilization was likely due to higher microbial biomass resulting in higher microbial $\mathrm{N}$ demand.

Initial soil characteristics data confirmed farmers' assessment that the $\mathrm{CH} 1$ field is less degraded than the $\mathrm{CH} 2$ field. Soil organic carbon content was lowered by $44 \%$ at the $\mathrm{CH} 2$ site as compared to the more fertile $\mathrm{CH} 1$ field. Total $\mathrm{N}$ content was reduced by $29 \%$ at $\mathrm{CH}$ 2. In addition, the depletion of exchangeable cations and available nutrients was much higher in the $\mathrm{CH} 2$ field. In contrast to all measured nutrients a higher $\mathrm{Mn}$ content was prevalent at $\mathrm{CH} 2$ probably due to a lower soil $\mathrm{pH}$. The soil data also suggested a degradation of the microbiological soil component (Table 8). This was indicated by the significantly lower soil microbial biomass carbon content and enzymes activities at the degraded $\mathrm{CH} 2$ site as compared to the non-degraded $\mathrm{CH} 1$ site.

From these findings it is apparent that intensive land use systems on the subsistence level cannot maintain SOM and nutrient levels and are responsible for severe soil degradation in the savanna agroecosystems. The soils which are poor in SOM and available nutrient status are also characterized by lower biological activity as it was indicated by lower microbial biomass and enzyme activities. As a consequence, at the degraded $\mathrm{CH} 2$ site a lower nutrient turnover with subsequently lower nutrient availability is expected. 


\subsubsection{Maize grain yields}

\section{Maize grain yields in 1993}

Maize grain yields of the first year (1993) of the controls should reflect initial soil fertility status. In 1993 both fields showed significant differences in their yield level, resulting in $1.4 \mathrm{t} \mathrm{ha}^{-1}$ at $\mathrm{CH} 1$ and only $0.6 \mathrm{t} \mathrm{ha}^{-1}$ at $\mathrm{CH} 2$ in the control plots (Table 9). This was in accordance with the initial characterization of the study sites by soil parameters revealing a very low soil fertility status at $\mathrm{CH} 2$. Consequently, differences in productivity of the control can be attributed to differences in soil fertility due to different land use history.

With complete mineral fertilization (All) or with combined mineral plus organic fertilizer input (All org) maize grain yields at the less fertile $\mathrm{CH} 2$ site exceeded by 23 and $21 \%$, respectively, to the yield level at the non-degraded $\mathrm{CH} 1$ site. This is a clear indication that soil fertility constraints could be compensated by mineral and organic fertilizer inputs in the first season.

In the unfertilized control and in the $(-\mathrm{N})$ treatments maize grain yields were the lowest of all treatments at both locations reflecting severe $\mathrm{N}$ deficiency. Maize grain yields at $\mathrm{CH} 1$ were double as high as at the degraded $\mathrm{CH} 2$ site for both treatments.

Relative to the treatment with all nutrients applied (All), the subtractive(-P) treatment did not significantly reduce yields at $\mathrm{CH} 1$, but at the degraded $\mathrm{CH} 2$ site $\mathrm{P}$ deficiency reduced maize grain yields by $67 \%$. With respect to the other subtractive treatments (-K, - Ca, - Mg, -S and -Mo) no differences were obtained as compared to treatment (All) at $\mathrm{CH}$ 1. At $\mathrm{CH} 2$, without $\mathrm{Mg}$ application (-Mg) maize grain yield was significantly lower. The combined application of mineral fertilizer with cotton seed waste (All org) did not significantly increase maize grain yields as compared to mineral fertilizer application alone (All) at both locations.

\section{Maize grain yields in 1994}

In the second cropping season the effects of the various fertilizer inputs on maize grain yields were very similar as in 1993 (Table 9). Maize grain yield in the control and (-N) treatments was significantly lower than in the other treatments. In contrast to the results obtained in 1993, grain yield in the (-P) treatment was significantly lower than in the complete fertilized plots (All) at both locations. 
Table 9: $\quad$ Maize grain yields $\left(\mathrm{t} \mathrm{ha}^{-1}\right)$ in the minus-one trials from 1993 - 1995.

\begin{tabular}{|c|c|c|c|c|c|c|c|c|}
\hline \multirow[t]{2}{*}{ Treatment } & \multicolumn{8}{|l|}{ Year } \\
\hline & 1993 & 1994 & 1995 & Mean & 1993 & 1994 & 1995 & Mean \\
\hline & \multicolumn{4}{|c|}{ CH 1 (non-degraded) } & \multicolumn{3}{|c|}{ CH 2 (degraded) } & \\
\hline All & 4.0 & 4.2 & 4.0 & 4.1 & 4.9 & 4.0 & 3.8 & 4.2 \\
\hline All org & 4.4 & 4.4 & 4.7 & 4.5 & 5.3 & 4.1 & 4.8 & 4.7 \\
\hline$-\mathbf{N}$ & 1.2 & 1.4 & 1.0 & 1.2 & 0.6 & 0.9 & 0.6 & 0.7 \\
\hline$-\mathbf{P}$ & 3.6 & 3.3 & 3.0 & 3.3 & 1.6 & 1.2 & 0.9 & 1.2 \\
\hline$-K$ & 4.1 & 4.0 & 4.1 & 4.1 & 4.5 & 2.9 & 3.6 & 3.7 \\
\hline$-\mathrm{Ca} /$ org $^{+}$ & 4.2 & 2.5 & 2.5 & 3.1 & 5.1 & 1.8 & 2.1 & 3.0 \\
\hline -Mg & 3.7 & 4.3 & 3.8 & 3.9 & 4.3 & 3.8 & 3.7 & 3.9 \\
\hline$-S$ & 4.3 & 4.1 & 4.2 & 4.2 & 4.7 & 3.6 & 3.9 & 4.1 \\
\hline -Mo/-Zn ${ }^{++}$ & 4.2 & 4.3 & 4.0 & 4.2 & 5.1 & 4.1 & 3.9 & 4.4 \\
\hline none (control) & 1.4 & 1.8 & 1.2 & 1.5 & 0.6 & 0.8 & 0.5 & 0.6 \\
\hline Mean & 3.5 & 3.4 & 3.3 & 3.4 & 3.7 & 2.7 & 2.8 & 3.1 \\
\hline F-Test & $* * *$ & $* * *$ & $* * *$ & $* * *$ & $* * *$ & $* * *$ & $* * *$ & $* * *$ \\
\hline LSD (0.05) & 0.4 & 0.4 & 0.6 & 0.3 & 0.5 & 0.4 & 0.5 & 0.3 \\
\hline F-Test year & & $* * *$ & & & & $* * *$ & & \\
\hline LSD (0.05) & & 0.2 & & & & 0.2 & & \\
\hline $\begin{array}{l}\text { F-Test } \\
\text { year*treatment }\end{array}$ & & $* * *$ & & & & $* * *$ & & \\
\hline LSD (0.05) & & 0.6 & & & & 0.6 & & \\
\hline
\end{tabular}

${ }^{+}(-\mathrm{Ca} /$ org) was (-Ca) in 1993 and replaced by (org) in 1994 and 1995.

${ }^{++}(-\mathrm{Mo} /-\mathrm{Zn})$ was $(-\mathrm{Mo})$ in 1993 and replaced by $(-\mathrm{Mo} /-\mathrm{Zn})$ in 1994 and 1995.

In 1994, at the degraded CH 2 site also K occurred as a limiting nutrient for maize grain yield. In the (-K) treatment grain yield was significantly reduced (28\%) as compared to the complete fertilized treatment (All). One reason for this decline in the (-K) plots at this site might have been a short dry spell during the early growing stages in July 1994 (Figure 3). Maize plants which did not receive $\mathrm{K}$ fertilizer were more affected by water stress as indicated by rolling maize leaves. Maize did not show any water deficiency symptoms in plots with mineral $\mathrm{K}$ application. 
In 1993 the (-Ca) treatment did not show yield effects. Therefore, in 1994, it was replaced by cotton seed waste application (org). This change caused a strong yield decline by $40 \%$ at $\mathrm{CH} 1$ and by $65 \%$ at $\mathrm{CH} 2$, because the amount of nutrients applied with cotton seed waste (Table 5) was much lower than in the (-Ca) treatment in 1993.

A yield comparison between the first (1993) and second season (1994) was difficult because grain yields in 1994 were more affected by pests, diseases, and a short dry spell than in 1993. At CH 1, maize grain yield did not change from 1993 to 1994, whereas at CH 2 mean grain yield across all treatments declined by $27 \%$. This indicates that stress could be tolerated much better at $\mathrm{CH} 1$ (non-degraded) than at the degraded site $\mathrm{CH} 2$.

\section{Maize grain yields in 1995}

In comparison to 1993 and 1994, maize yield in the control and (-N) treatments in 1995 was lower than in the other treatments at both locations (Table 9). In the (-P) treatment grain yield was significantly reduced by $25 \%$ at $\mathrm{CH} 1$ and by $76 \%$ at $\mathrm{CH} 2$, as compared to the complete mineral fertilization (All). Cotton seed waste application (org) gave maize grain yield that were lower by $38 \%$ at $\mathrm{CH} 1$ and by $45 \%$ at $\mathrm{CH} 2$ as compared to complete mineral fertilization (All). Compared to the unfertilized control, yield increased by $108 \%$ at $\mathrm{CH} 1$ and by $320 \%$ at the degraded $\mathrm{CH} 2$ site after using cotton seed waste as organic fertilizer. Mineral fertilizer combined with cotton seed waste application (All org) increased maize grain yield by $18 \%$ at $\mathrm{CH} 1$ and by $26 \%$ at $\mathrm{CH} 2$ as compared to the complete fertilized treatment (All).

\section{Average grain yield across three experimental years (1993 - 1995)}

The two-way ANOVA on grain yield from 1993 - 1995 revealed treatment, year and the interaction to have significant effects at both locations (Table 9). The differences in grain yield between years of selected treatments might indicate a change in productivity and in soil fertility due to sequential cropping and differential fertilization. Without mineral and organic amendments grain yield was determined by initial fertility status and nutrient supply capacity of the soil. Maize grain yield was significantly affected by soil $\mathrm{P}$ at both sites. Average grain yield across three years was significantly lower in the (-P) treatment than with complete fertilization at $\mathrm{CH} 1$ and $\mathrm{CH} 2$ (Table 9). However, average grain yield in the (-P) treatment was significantly higher than in the control at both locations. 
At the non-degraded location $\mathrm{CH} 1$, the lower yield level and the decreasing trend in the subtractive (-P) treatment indicated moderate $\mathrm{P}$ deficiency. On average across the years, limited soil P supply reduced yield by $20 \%$ as compared to complete fertilization (All). At the degraded $\mathrm{CH} 2$ site, shortage in P supply was more severe as indicated by a drastic yield reduction of $71 \%$. Consequently, $\mathrm{P}$ was ranked as second limiting nutrient for maize grain production at both sites. At either location soil $\mathrm{P}$ deficiency could be compensated for by addition of $\mathrm{P}$ fertilizer.

Maize grain yields did not vary much from 1993 to 1995 in the complete fertilized plots (All) and in the subtractive $(-\mathrm{K}),(-\mathrm{Mg})$, and $(-\mathrm{S})$ treatments at the non-degraded $\mathrm{CH} 1$ site (Table 9). By using mineral fertilizer and additional cotton seed waste (All org) grain yield was the highest through the years $\left(4.4-4.7 \mathrm{t} \mathrm{ha}^{-1}\right)$. In the (-P) treatment grain yield decreased from 3.6 to $3.0 \mathrm{t} \mathrm{ha}^{-1}(17 \%)$ during three consecutive maize cropping years. Although this change was not significant, it might indicate decreasing $\mathrm{P}$ supply at the non-degraded $\mathrm{CH} 1$ site. Other nutrients were in adequate supply.

Cotton seed waste (org) had a positive effect on maize grain yield $\left(2.5 \mathrm{t} \mathrm{ha}^{-1}\right)$ as compared to the control $\left(1.2-1.8 \mathrm{tha}^{-1}\right)$. Thus, the use of cotton seed waste could improve nutrient supply to maize. However, only in combination with a complete mineral fertilizer application it was possible to avoid yield decline during three consecutive maize cropping seasons.

In contrast, at $\mathrm{CH} 2$ grain yield declined significantly in all treatments from 1993 to 1995 (Table 9). Declining yields were amounted to the treatments All (22\%), -P (44\%), $-\mathrm{K}(20 \%),-\mathrm{Mg}(14 \%),-\mathrm{S}(17 \%)$, and $-\mathrm{Mo} / \mathrm{Zn}(24 \%)$. In the $(-\mathrm{N})$ and control plots grain yields remained almost unchanged on a very low level $\left(0.5-0.9 \mathrm{t} \mathrm{ha}^{-1}\right)$. As was already observed at $\mathrm{CH}$ 1, only through a combination of mineral fertilizer with additional cotton seed waste, grain yields were stabilized at high levels at the degraded $\mathrm{CH} 2$ site.

The results show that the $\mathrm{CH} 2$ soil is severely degraded. Consecutive maize cropping during three years increased $\mathrm{P}$ deficiency. $\mathrm{N}$ deficiency was clearly expressed by the stable but low yield levels over the years. In the mineral fertilized plots, although mineral fertilizer was applied at apparent adequate levels, maize grain yields declined from 1993 to 1995. This drastic yield reduction, was observed only in the degraded $\mathrm{CH} 2$ soil indicating an exhausting, non-sustainable crop management. In the complete fertilized treatments (All), other nutrients than those supplied may have caused this yield reduction 
and other factors may have played a role as well. The low yields obtained without $\mathrm{N}$ and $\mathrm{P}$ fertilization suggest these two nutrients as the major limiting factors in crop production in the study area in northern Ghana. Sustainable increased crop production needs $\mathrm{N}$ and $\mathrm{P}$ input. The results showed that at the degraded site also $\mathrm{K}$ application is recommended. However, maize grain yield data implies that fertility management of highly degraded soils cannot be based on chemical fertilization alone. This was evident from much stronger positive effects of cotton seed waste on grain yields at the degraded $\mathrm{CH} 2$ soil, indicating that lack of organic substrates in the soil were possible limiting factors for soils nutrient supply and might be held responsible for loss of soil quality.

\subsubsection{Maize nutrient concentration and nutrient uptake}

Plant samples were analyzed for nutrient concentration only at final harvest of the third cropping cycle. These samples should reflect cumulative fertilizer effects of the previous three seasons. Nutrient concentrations in maize grain (Annex, Table 45) and maize stover (Annex, Table 46) clearly showed the influence of $\mathrm{N}, \mathrm{P}, \mathrm{K}$ and $\mathrm{Mg}$ application at both sites. In the (-N) and control plots $\mathrm{N}$ concentrations were significantly lower in maize grain and stover indicating $\mathrm{N}$ deficiency. Phosphorus, $\mathrm{K}$, and $\mathrm{Mg}$ concentrations in grain and stover were slightly lower in the subtractive treatments as compared to the complete fertilized treatment (All). For $\mathrm{Ca}, \mathrm{Mn}$ and $\mathrm{Zn}$ concentrations, no differences were detected in maize grain and straw.

Nutrient uptake by grain (Annex, Table 47) and straw (Annex, Table 48) was calculated by multiplying nutrient concentration with grain and straw yield. The amount of nutrients removed with harvested products (grain) and crop residues (stover) is important for estimating a nutrient balance. Grains were exported from the fields at harvest whereas stover was returned to the fields as crop residues. Maize grain and stover yields, but also nutrient uptake by grain and stover, increased significantly upon complete mineral fertilizer application (All) as compared to the control plots. The main limiting nutrients for nutrient uptake by grain and stover were $\mathrm{N}$ at $\mathrm{CH} 1$ and $\mathrm{N}$ and $\mathrm{P}$ at $\mathrm{CH}$ 2. As shown in Table 47 and 48 it was evident that soil degradation could be largely compensated by complete fertilization. 


\section{N uptake}

In the control plots low yield levels of about 0.5 and $1.2 \mathrm{t} \mathrm{ha}^{-1}$ of grain extracted about 12 and $26 \mathrm{~kg} \mathrm{~N} \mathrm{ha}^{-1}$ from the soil at $\mathrm{CH} 2$ and $\mathrm{CH} \mathrm{1,} \mathrm{respectively} \mathrm{(Table} \mathrm{10).}$ This should reflect $\mathrm{N}$-supplying capacity of the soils. As expected from the results of grain and straw yields in both fields, total $\mathrm{N}$ uptake was significantly higher in plots which had received mineral and/or organic $\mathrm{N}$ fertilizer as compared to the control and the $(-\mathrm{N})$ treatments.

At $\mathrm{CH} 1$, with the exception of the (-P) and $(-\mathrm{Mg})$ treatments, in plots fertilized with mineral $\mathrm{N}$, uptake of nitrogen by total maize plants was similar to the amount of fertilizer $\mathrm{N}$ applied $\left(100 \mathrm{~kg} \mathrm{~N} \mathrm{ha}^{-1}\right)$. At $\mathrm{CH} \mathrm{2,} \mathrm{with} \mathrm{the} \mathrm{exception} \mathrm{of} \mathrm{the} \mathrm{(-Mo/-Zn)}$ treatment, $\mathrm{N}$ uptake by maize remained slightly below mineral $\mathrm{N}$ application.

Phosphorus application improved $\mathrm{N}$ uptake at both sites, indicating that soil $\mathrm{P}$ supply was a limiting factor for maize biomass production and $\mathrm{N}$ uptake. In the complete fertilized treatment with additional cotton seed waste (All org), maize biomass production and $\mathrm{N}$ uptake was the highest. The values were very similar at both sites. Nitrogen accumulation by above ground maize plants was close to the amount of $\mathrm{N}$ applied by mineral and organic fertilizers $\left(133 \mathrm{~kg} \mathrm{~N} \mathrm{ha}^{-1}\right)$. These results indicate that a balanced mineral and organic fertilizer use could compensate for severe $\mathrm{N}$ limitations prevailing at both sites.

\section{P uptake}

There was a large response in $\mathrm{P}$ concentration of grain (Table 45) and straw (Table 46), in grain (Table 47) and straw yields (Table 48) and in P uptake (Table 47 and Table 48) to $\mathrm{P}$ fertilizer application at both sites. P-uptake values in the control plots were lowest, indicating a pronounced $\mathrm{P}$ deficiency in the both soils (Table 10).

$\mathrm{N}$ application increased $\mathrm{P}$ uptake due to higher plant biomass production and also may be due to higher absorption surface for $\mathrm{P}$ as a result of better root growth. This might be the reason for the significant difference in $\mathrm{P}$ uptake between the (-P) treatment, which received mineral $\mathrm{N}$ but no $\mathrm{P}$ fertilizer and the unfertilized control in the non-degraded $\mathrm{CH} 1$ soil. In general, P-uptake values remained far below the amount of $\mathrm{P}$ applied ( $\leq 1 / 3$ of $\mathrm{P}$ applied). 
Table 10: Total aboveground biomass yield $\left(\mathrm{t} \mathrm{ha}^{-1}\right)$ and uptake of $\mathrm{N}, \mathrm{P}, \mathrm{K}, \mathrm{Ca}, \mathrm{Mg}, \mathrm{Mn}$ and $\mathrm{Zn}\left(\mathrm{kg} \mathrm{ha}^{-1}\right)$ of maize as affected by different nutrient applications in the minus-one trials. Location $\mathrm{CH} 1$ (not degraded) and $\mathrm{CH} 2$ (degraded).

\begin{tabular}{|c|c|c|c|c|c|c|c|c|}
\hline Treatment & $\begin{array}{c}\text { Total maize } \\
\text { biomass }\end{array}$ & $\mathbf{N}$ & $\mathbf{P}$ & $\mathbf{K}$ & $\mathbf{C a}$ & Mg & Mn & Zn \\
\hline \multicolumn{9}{|c|}{ CH 1 (not degraded) } \\
\hline All & 8.4 & 109 & 21 & 135 & 3.9 & 7.5 & 0.4 & 0.18 \\
\hline All org & 9.9 & 123 & 25 & 187 & 5.5 & 9.5 & 0.4 & 0.22 \\
\hline$-\mathbf{N}$ & 2.7 & 25 & 6 & 40 & 1.3 & 2.4 & 0.1 & 0.07 \\
\hline$-\mathbf{P}$ & 6.7 & 82 & 13 & 102 & 3.7 & 6.5 & 0.3 & 0.22 \\
\hline$-K$ & 8.5 & 108 & 22 & 122 & 4.5 & 8.6 & 0.4 & 0.20 \\
\hline -Ca/org & 4.7 & 52 & 11 & 64 & 2.1 & 3.8 & 0.2 & 0.12 \\
\hline$-\mathrm{Mg}$ & 7.3 & 96 & 20 & 109 & 3.7 & 6.5 & 0.3 & 0.17 \\
\hline$-\mathrm{S}$ & 9.2 & 111 & 23 & 148 & 4.6 & 8.2 & 0.4 & 0.21 \\
\hline -Mo/-Zn & 8.7 & 109 & 22 & 147 & 4.0 & 7.5 & 0.4 & 0.17 \\
\hline None & 2.7 & 26 & 6 & 36 & 1.3 & 2.3 & 0.1 & 0.08 \\
\hline Mean & 6.9 & 84 & 17 & 109 & 3.5 & 6.3 & 0.3 & 0.16 \\
\hline LSD & 1.2 & 16 & 3 & 18 & 0.8 & 1.1 & 0.1 & 0.03 \\
\hline F-Test & $* * *$ & $* * *$ & $* * *$ & $* * *$ & $* * *$ & $* * *$ & $* * *$ & $* * *$ \\
\hline
\end{tabular}

CH 2 (degraded)

\begin{tabular}{lrrrrrrrr} 
All & 8.0 & 95 & 21 & 110 & 5.5 & 7.9 & 0.7 & 0.18 \\
All org & 9.9 & 126 & 25 & 155 & 6.6 & 9.8 & 0.8 & 0.24 \\
-N & 1.6 & 14 & 4 & 22 & 0.9 & 1.4 & 0.1 & 0.05 \\
-P & 2.5 & 33 & 3 & 35 & 1.8 & 2.6 & 0.4 & 0.12 \\
-K & 7.4 & 95 & 18 & 88 & 5.6 & 8.6 & 0.7 & 0.20 \\
-Ca/org & 4.5 & 44 & 10 & 54 & 2.7 & 3.9 & 0.5 & 0.11 \\
-Mg & 8.3 & 98 & 20 & 112 & 6.3 & 7.4 & 0.9 & 0.17 \\
-S & 8.4 & 96 & 20 & 137 & 5.5 & 7.4 & 0.8 & 0.20 \\
-Mo/-Zn & 8.5 & 101 & 22 & 115 & 6.2 & 8.9 & 0.9 & 0.17 \\
None & 1.3 & 12 & 2 & 15 & 0.9 & 1.1 & 0.2 & 0.03 \\
Mean & 6.0 & 71 & 14 & 84 & 4.2 & 5.9 & 0.6 & 0.15 \\
LSD & 1.2 & 15 & 5 & 36 & 1.1 & 1.8 & 0.1 & 0.04 \\
F-Test & $* * *$ & $* * *$ & $* * *$ & $* * *$ & $* * *$ & $* * *$ & $* * *$ & $* * *$ \\
\hline
\end{tabular}




\section{K, Ca, Mg, Mn and Zn uptake}

Uptake pattern of $\mathrm{K}, \mathrm{Ca}, \mathrm{Mg}, \mathrm{Mn}$, and $\mathrm{Zn}$ by total maize plant followed the same trends found for maize grain and straw. Cation uptake rates were generally determined by total maize biomass production which was significantly dependent on $\mathrm{N}$ and $\mathrm{P}$ fertilization.

The differences in uptake of cations between the unfertilized control and the complete fertilized treatment (All) were always significant. In the subtractive treatments uptake of the different cations was not significantly lower as compared to complete fertilization (All). In the subtractive treatments uptake of cations was always significantly higher relative to the control. Apart from (-N), in all $\mathrm{K}$ fertilized plots $\mathrm{K}$ uptake by maize was much higher than $\mathrm{K}$ input by fertilizer addition. Moreover, $\mathrm{K}$ uptake by maize straw was higher than by maize grain.

\subsubsection{Conclusions on maize yields and nutrient uptake}

Maize grain yields have proved to be general indicators of soil fertility and crop performance. Apart from climatic factors like variability in rainfall distribution maize production in this agroecosystem was determined by declining productivity as a consequence of declining soil fertility. The loss of soil fertility was estimated via crop production in the unfertilized control treatments. The major constraints on the achievement of higher maize yields are low inherent $\mathrm{N}$ and $\mathrm{P}$ supplies by the soils.

Without fertilizer inputs maize grain yield remained at low levels $\left(0.5-1.4 \mathrm{t} \mathrm{ha}^{-1}\right)$ which is reflecting farmer's yields in the area. Fertilization raised maize production levels significantly, particularly when the most limiting nutrients $\mathrm{N}$ and $\mathrm{P}$ were supplied. Maize yield under well managed conditions reached levels of about $4-5 \mathrm{t}_{\text {grain }} \mathrm{ha}^{-1}$ with an input of $100 \mathrm{~kg} \mathrm{Nha}^{-1}, 60 \mathrm{~kg} \mathrm{Pha}^{-1}, 60 \mathrm{~kg} \mathrm{Kha}^{-1}$ and $25 \mathrm{~kg} \mathrm{Mg} \mathrm{ha}^{-1}$.

As established from the complete fertilized treatments (All) with sufficient nutrients applied, maize grain yields remained almost unchanged on a relatively high level (4.0 and $4.1 \mathrm{t} \mathrm{ha}^{-1}$ ) at the more fertile $\mathrm{CH} 1$ site indicating a better and more sustainable productivity potential at this location. At the degraded $\mathrm{CH} 2$ site, grain yield in the complete fertilized treatment showed a declining trend from 4.9 to $3.8 \mathrm{t} \mathrm{ha}^{-1}$ over three years. Only by using mineral fertilizer at adequate levels in combination with organic fertilizer it was possible to achieve grain yields at a high level $\left(\geq 4 \mathrm{tha}^{-1}\right)$ over three years. 
Grain yields alone are not sufficient to evaluate sustainability potential of food production. Methods to measure and predict soil fertility and soil quality must be included to describe short term changes in soil fertility and soil productivity.

Land degradation and subsequent deterioration of soil fertility are found to be the main causes of a decline in agricultural production in the savanna region of northern Ghana. Agriculture in this area with soils of low inherent fertility requires inputs to avoid loss of soil quality and to achieve sustainability. In this respect a combination of mineral and organic fertilizer application established to be the best way of fertilization. Moreover, whatever the soil, depleted or enriched in available soil nutrients, crop residues have to be left in the fields in sustainable farming systems.

A total dry matter production of $6-10 \mathrm{t} \mathrm{ha}^{-1}$ involves an uptake by the maize crop of $80-130 \mathrm{~kg} \mathrm{~N} \mathrm{ha}^{-1}, 20-25 \mathrm{~kg} \mathrm{P} \mathrm{ha}^{-1}$ and $100-200 \mathrm{~kg} \mathrm{~K} \mathrm{ha}^{-1}$. Of these totals, about $50-90 \mathrm{~kg} \mathrm{~N} \mathrm{ha}^{-1}, 10-20 \mathrm{~kg} \mathrm{P} \mathrm{ha}{ }^{-1}$ and $30-60 \mathrm{~kg} \mathrm{~K} \mathrm{ha}^{-1}$ was in the grain. The remainder is in crop residues. The potential benefit to the soil of the nutrients stored in crop residues and subsequently released by decomposition can be estimated from straw data with about $20-30 \mathrm{~kg} \mathrm{~N} \mathrm{ha}^{-1}, 2-3 \mathrm{~kg} \mathrm{P} \mathrm{ha}^{-1}$ and $50-120 \mathrm{~kg} \mathrm{~K} \mathrm{ha}^{-1}$. Thus, with crop residues management especially $\mathrm{K}$ removal could be minimized but, also other nutrient losses from the system would be lowered.

Under conditions of low farming intensity there might be no benefits of applying $\mathrm{K}$ despite the low $\mathrm{K}$ status of the savanna soils. The results on $\mathrm{K}$ concentration and $\mathrm{K}$ uptake by maize straw have clearly shown that under intensive maize cultivation $\mathrm{K}$ might become an important yield limiting nutrient and, thus has to be monitored carefully.

Other secondary nutrients such as $\mathrm{Ca}$ and $\mathrm{S}$ and micro-nutrients deficiencies (Mn, Mo, Zn) were of less importance and nutrient deficiency in maize have not been detected. Since concentrations of the nutrients in the soils were very low they have to be monitored carefully in order to avoid deficiency in the future. 


\subsection{Dynamics of chemical soil parameters under maize from 1993 until 1995}

\subsubsection{Soil pH}

At both sites consecutive maize cropping for three years resulted in a progressive decline in soil $\mathrm{pH}$ (Table 11). The decline was lowest in the (-N) and in the control treatments, indicating that the main cause for this acidification trend could have been the annual application of urea fertilizer. This effect was not found to be significant at the $5 \%$ level with respect to the individual sampling times. Urea contains nitrogen in ammonium form and nitrification reactions result in soil acidification. There was also a slight decrease in $\mathrm{pH}$ in the (-N) and control treatments indicating that maize cultivation might enhance acidity probably through SOM mineralization and cation removal, for instance $\mathrm{K}, \mathrm{Ca}$ and $\mathrm{Mg}$, even at low yield levels. Soil $\mathrm{pH}$ was generally lower at the degraded $\mathrm{CH} 2$ site throughout the years and in all treatments. The very low SOM content at $\mathrm{CH} 2$ could be the cause for stronger acidification and lower buffering capacity at this degraded site.

The soil reaction is an important soil quality indicator. In general, a decreasing soil $\mathrm{pH}$ indicates soil degradation. Soil $\mathrm{pH}$ influences the solubility of nutrients and it also affects the activity of microorganisms responsible for breaking down organic matter and most chemical transformations. Soil $\mathrm{pH}$ thus affects the availability of several plant nutrients.

\subsubsection{Soil organic carbon}

The study sites differed strongly in their soil organic carbon $\left(\mathrm{C}_{\mathrm{org}}\right)$ content (Table 12). At $\mathrm{CH} 2, \mathrm{C}_{\text {org }}$ was $43 \%$ lower than at $\mathrm{CH} 1$. Individual sampling dates did not show significant treatment effects and fluctuations over time were only different at the $6 \%$ level at the non-degraded $\mathrm{CH} 1$ site. At the degraded $\mathrm{CH} 2$ site, $\mathrm{C}_{\text {org }}$ was lowest in the control treatment at the end of the third season (October 1995). A similar trend was observed in the (-N) plots after three years of consecutive maize cropping without $\mathrm{N}$ application.

At $\mathrm{CH} 2$, significant differences between the sampling dates revealed an increase of $\mathrm{C}_{\text {org }}$ with time. These results suggest that high-input maize cropping systems might provide sufficient organic inputs to maintain $\mathrm{C}_{\text {org }}$ levels. However, for evaluating these systems with respect to maintenance of SOM and moreover to detect changes and fluxes of $\mathrm{C}_{\text {org }}$ they have to be monitored for a longer time period. 
Table 11: Dynamics of soil pH in the $0-30 \mathrm{~cm}$ layer from June 1993 to October 1995. Locations: $\mathrm{CH} 1$ and $\mathrm{CH} 2$.

\begin{tabular}{|c|c|c|c|c|c|c|}
\hline \multirow[b]{2}{*}{ Treatment } & \multicolumn{6}{|c|}{ Sampling date } \\
\hline & $06 / 93$ & $10 / 93$ & $06 / 94$ & $10 / 94$ & $06 / 95$ & $10 / 95$ \\
\hline \multicolumn{7}{|c|}{ CH 1 (non-degraded) } \\
\hline All & 6.0 & 5.7 & 6.3 & 5.7 & 5.7 & 5.5 \\
\hline All org & 6.2 & 5.8 & 6.4 & 5.7 & 5.8 & 5.5 \\
\hline$-\mathbf{N}$ & 6.1 & 5.8 & 6.5 & 5.8 & 5.9 & 5.9 \\
\hline$-\mathbf{P}$ & 6.1 & 5.9 & 6.5 & 5.8 & 5.9 & 5.6 \\
\hline$-\mathbf{K}$ & 6.2 & 5.8 & 6.4 & 5.7 & 5.9 & 5.7 \\
\hline -Ca/org & 6.2 & 5.7 & 6.6 & 5.6 & 5.8 & 5.7 \\
\hline -Mg & 6.0 & 5.8 & 6.3 & 5.8 & 5.9 & 5.7 \\
\hline$-S$ & 6.3 & 5.8 & 6.3 & 5.6 & 5.7 & 5.6 \\
\hline -Mo/-Zn & 6.1 & 5.8 & 6.3 & 5.7 & 5.7 & 5.5 \\
\hline none & 6.2 & 6.0 & 6.4 & 5.9 & 5.9 & 5.9 \\
\hline LSD (0.05) & 0.2 & ns & ns & ns & ns & ns \\
\hline Mean & 6.1 & 5.8 & 6.4 & 5.7 & 5.8 & 5.7 \\
\hline \multicolumn{7}{|l|}{${ }^{a} \operatorname{LSD}(\mathbf{0 . 0 6})$} \\
\hline \multicolumn{7}{|c|}{ CH 2 (degraded) } \\
\hline All & 5.8 & 5.5 & 5.5 & 5.3 & 5.2 & 5.0 \\
\hline All org & 5.7 & 5.6 & 5.5 & 5.4 & 5.1 & 5.0 \\
\hline$-\mathbf{N}$ & 5.6 & 5.6 & 5.5 & 5.5 & 5.3 & 5.3 \\
\hline$-P$ & 5.6 & 5.5 & 5.3 & 5.3 & 5.1 & 4.6 \\
\hline$-\mathbf{K}$ & 5.7 & 5.6 & 5.5 & 5.3 & 5.1 & 5.0 \\
\hline -Ca/org & 5.7 & 5.4 & 5.4 & 5.2 & 5.0 & 5.1 \\
\hline -Mg & 5.7 & 5.5 & 5.6 & 5.4 & 5.2 & 5.0 \\
\hline$-S$ & 5.7 & 5.6 & 5.5 & 5.3 & 5.2 & 4.9 \\
\hline -Mo/-Zn & 5.6 & 5.5 & 5.3 & 5.3 & 5.1 & 5.0 \\
\hline none & 5.6 & 5.6 & 5.4 & 5.3 & 5.2 & 5.2 \\
\hline LSD (0.05) & ns & ns & ns & ns & ns & 0.2 \\
\hline Mean & 5.7 & 5.5 & 5.4 & 5.3 & 5.1 & 5.0 \\
\hline${ }^{\mathrm{a}} \mathbf{L S D}(\mathbf{0 . 0 5})$ & 0.1 & & & & & \\
\hline
\end{tabular}

${ }^{a}$ LSD-test for significant differences of the sampling dates after 2-way ANOVA across pooled treatments. 
In the literature losses of SOM and subsequently of soil fertility due to continuous cropping and nutrient mining in the tropics are widely reported. AYANABA et al. (1976) found losses of 10 to $30 \%$ of SOM following two years of maize, with and without return of residues, respectively, compared with that of the bush fallow. WICK (1997) reported that in the forest transition zone of southern Nigeria the average loss of organic $\mathrm{C}$ in the $0-10 \mathrm{~cm}$ soil layers increased with time of cropping and was influenced by land use history. The average total loss of organic C after 14, 10 and 4 years of continuos cropping were $76 \%, 68 \%$ and 50 $\%$. Comparable results were reported by LAL (1989), showing that organic C declined by about $70 \%$ from initially $2.4 \%$ to $0.7 \%$ in the $0-5 \mathrm{~cm}$ layer after continuous cropping for five years. Carbon declines with cultivation under savanna, although much slower than under forest, resulting in lower levels after several years because of the much lower plant biomass production of savanna compared to forests (LOGAN, 1990).

Organic matter provides a carbon and energy source for soil microbes. In low-input cropping systems SOM is the major source of nutrients in the soil. The cycling of these nutrients is the principal mechanism for nutrient supply and the soils may be considered as biological entities with complex biochemical reactions (DICK, 1994). Under suitable environmental conditions, the extent of SOM turnover is mainly controlled by the size and activity of the microbial biomass (MARTENS, 1995). This is why microbial indicators have been used to characterize soil quality with respect to land use and/or soil management (TuRCO et al., 1994).

\subsubsection{Total nitrogen}

Soil total $\mathrm{N}$ content followed similar trends as organic carbon and was significantly lower at $\mathrm{CH} 2$ (degraded). At both sites, no significant treatment effects were found at each of the sampling dates (Table 13). Average total $\mathrm{N}$ across treatments fluctuated significantly between sampling dates showing a negative trend with time until the third cropping season at $\mathrm{CH}$ 1. The strongest decline was found without $\mathrm{N}(17 \%)$ and in the control plots $(28 \%)$ where lower amounts of crop residues were restituted. This indicates a possible depletion of the stable organic $\mathrm{N}$ pool due to $\mathrm{N}$ mineralization during the cultivation cycle when no $\mathrm{N}$ fertilizer was applied. At $\mathrm{CH} 2$, a decreasing, though non-significant trend across three maize cropping seasons was found in the $(-\mathrm{N}),(-\mathrm{Mg})$ and $(-\mathrm{Mo} /-\mathrm{Zn})$ treatments with a decrease of $5 \%, 10 \%$ and $7 \%$, respectively. 
Table 12: Dynamics of soil organic carbon $\left(\mathrm{C}_{\mathrm{org}}\right)$ content in the $0-30 \mathrm{~cm}$ layer $\left(\mathrm{t} \mathrm{ha}^{-1}\right)$ from June 1993 - October 1995. Locations: CH 1 and CH 2.

\begin{tabular}{|c|c|c|c|c|c|c|}
\hline \multicolumn{7}{|c|}{ Sampling date } \\
\hline Treatment & $06 / 93$ & $10 / 93$ & $06 / 94$ & $10 / 94$ & $06 / 95$ & $10 / 95$ \\
\hline \multicolumn{7}{|c|}{ CH 1 (non-degraded) } \\
\hline All & 36 & 35 & 38 & 33 & 34 & 36 \\
\hline All org & 39 & 40 & 40 & 39 & 38 & 39 \\
\hline$-\mathbf{N}$ & 36 & 34 & 38 & 34 & 35 & 34 \\
\hline$-P$ & 40 & 41 & 44 & 39 & 37 & 40 \\
\hline$-\mathbf{K}$ & 38 & 40 & 40 & 37 & 35 & 40 \\
\hline -Ca/org & 37 & 37 & 40 & 38 & 36 & 39 \\
\hline$-\mathrm{Mg}$ & 40 & 37 & 41 & 37 & 37 & 39 \\
\hline$-S$ & 33 & 40 & 41 & 37 & 39 & 40 \\
\hline -Mo/-Zn & 36 & 35 & 37 & 36 & 36 & 37 \\
\hline none & 38 & 38 & 39 & 35 & 35 & 38 \\
\hline LSD (0.05) & ns & ns & ns & ns & ns & ns \\
\hline Mean & 37 & 38 & 40 & 36 & 36 & 38 \\
\hline${ }^{a} \operatorname{LSD}(\mathbf{0 . 0 6})$ & $2^{b}$ & & & & & \\
\hline \multicolumn{7}{|c|}{ CH 2 (degraded) } \\
\hline All & 23 & 23 & 31 & 24 & 25 & 28 \\
\hline All org & 21 & 19 & 26 & 22 & 21 & 29 \\
\hline$-\mathbf{N}$ & 20 & 17 & 27 & 20 & 21 & 25 \\
\hline$-\mathbf{P}$ & 21 & 19 & 26 & 21 & 21 & 27 \\
\hline$-K$ & 22 & 20 & 26 & 21 & 23 & 31 \\
\hline -Ca/org & 21 & 19 & 25 & 22 & 21 & 29 \\
\hline$-M g$ & 23 & 21 & 27 & 23 & 23 & 27 \\
\hline$-S$ & 20 & 19 & 29 & 24 & 22 & 26 \\
\hline -Mo/-Zn & 22 & 21 & 31 & 22 & 23 & 26 \\
\hline none & 20 & 18 & 28 & 21 & 21 & 24 \\
\hline LSD (0.05) & ns & ns & ns & ns & ns & 6 \\
\hline Mean & 21 & 20 & 28 & 22 & 22 & 27 \\
\hline a ${ }^{\mathrm{a}} \mathrm{LSD}(\mathbf{0 . 0 5})$ & 1 & & & & & \\
\hline
\end{tabular}

${ }^{\mathrm{a}}$ LSD-test for significant differences of the sampling dates after 2-way ANOVA across pooled treatments

${ }^{\mathbf{b}}$ F-test for differences between sampling dates was only significant at the $6 \%$ level 
Several authors described a decline in organic $\mathrm{N}$ in tropical soils due to cropping of food crops. A rapid decline in organic $\mathrm{N}$ following clearing of forest or plowing of grasslands was reported by GREENLAND and NYE (1959) as cited by LOGAN (1990). Results presented by RHODES (1995) showed that the stable soil organic N pool was progressively depleted, even when mineral fertilizer was applied in the semidecidous forest zone of the Kumasi area in Ghana. The decline in the organic $\mathrm{N}$ content was parallel to that of organic matter. However, the change in the stable pool was smaller when the crop residues were restituted. Results obtained at IITA in the forest transition zone in Nigeria, showed that soil total $\mathrm{N}$ content declined strongly in the $0-5 \mathrm{~cm}$ layer by 45 to $68 \%$ under continuous cropping. Other data obtained at IITA, showed that total $\mathrm{N}$ declined by $75 \%$ after five years of continuous cropping under both, no-tillage and plow-till (LAL, 1989).

\subsubsection{Soil C-N-ratio}

Initial C-N-ratios were 13.3 at $\mathrm{CH} 1$ and 10.5 at $\mathrm{CH} 2$ (Table 14). Soil C-N-ratios fluctuated significantly between sampling dates without showing any trend which could be attributed to treatments. Level of microbial activity, $\mathrm{pH}$, drainage, and rainfall affect C-N-ratios in tropical soils (RHODES, 1988). The C-N-ratio in soils of West Africa has been shown to change little during cultivation (JONES and WILD, 1975; CRASWELL and VLEK, 1982). The decomposition rate of soil organic $\mathrm{C}$ is similar to that of soil organic $\mathrm{N}$ so that the mineralization rate is not affecting the C-N-ratio (NYe and GREENLAND, 1960).

\subsubsection{Bray-I phosphorus (available P)}

The experimental sites differed substantially in their Bray-I extractable P in the $0-30 \mathrm{~cm}$ soil layer (Table 15). On average, initial available $\mathrm{P}$ content was $8 \mathrm{ppm}$ at the more fertile $\mathrm{CH} 1$ site and $3 \mathrm{ppm}$ at the degraded $\mathrm{CH} 2$ site. Phosphorus fertilizer application $\left(60 \mathrm{~kg} \mathrm{P} \mathrm{ha}^{-1} \mathrm{year}^{-1}\right)$ resulted in temporal fluctuations of available $\mathrm{P}$.

A two-way ANOVA revealed highly significant differences for the different treatments and between sampling dates. Moreover, a highly significant interaction between treatment and sampling date $(p \leq 0.001)$ was found at the strongly degraded $\mathrm{CH} 2$ site.

The increase in soil available P content between June (before P fertilizer was applied) and October (at harvest) can be interpreted as residual $\mathrm{P}$ fertilizer. This effect was much stronger at $\mathrm{CH} 2$ which was characterized by a much lower initial soil Bray-I P content. 
Table 13: Dynamics of soil total $\mathrm{N}\left(\mathrm{N}_{\mathrm{tot}}\right)$ content in the $0-30 \mathrm{~cm}$ layer $\left(\mathrm{t} \mathrm{ha}^{-1}\right)$ from June 1993 to October 1995 in the minus-one trials. Locations: CH 1, CH 2.

\begin{tabular}{|c|c|c|c|c|c|c|}
\hline \multirow[b]{2}{*}{ Treatment } & \multicolumn{6}{|c|}{ Sampling date } \\
\hline & $06 / 93$ & $10 / 93$ & $06 / 94$ & $10 / 94$ & $06 / 95$ & $10 / 95$ \\
\hline \multicolumn{7}{|c|}{ CH 1 (non-degraded) } \\
\hline All & 2.7 & 2.8 & 3.1 & 3.0 & 2.3 & 2.4 \\
\hline All org & 2.8 & 3.2 & 3.3 & 3.4 & 2.5 & 2.7 \\
\hline$-\mathbf{N}$ & 2.9 & 2.8 & 3.0 & 2.8 & 2.3 & 2.4 \\
\hline$-\mathbf{P}$ & 3.1 & 3.3 & 3.3 & 3.4 & 2.8 & 2.7 \\
\hline$-\mathbf{K}$ & 3.0 & 3.1 & 3.3 & 3.3 & 2.5 & 2.6 \\
\hline -Ca/org & 2.7 & 3.0 & 3.2 & 3.4 & 2.6 & 2.6 \\
\hline$-M g$ & 3.1 & 2.9 & 3.3 & 3.2 & 2.6 & 2.7 \\
\hline$-S$ & 2.6 & 3.1 & 3.1 & 3.2 & 2.7 & 2.9 \\
\hline$-M o /-Z n$ & 2.9 & 2.7 & 3.1 & 3.0 & 2.5 & 2.6 \\
\hline none & 3.5 & 2.7 & 3.0 & 2.9 & 2.4 & 2.5 \\
\hline LSD $(0.05)$ & ns & ns & ns & ns & ns & ns \\
\hline Mean & 2.9 & 3.0 & 3.2 & 3.2 & 2.5 & 2.6 \\
\hline${ }^{a} \operatorname{LSD}(0.05)$ & 0.2 & & & & & \\
\hline \multicolumn{7}{|c|}{ CH 2 (degraded) } \\
\hline All & 2.2 & 2.6 & 2.2 & 2.3 & 1.8 & 2.3 \\
\hline All org & 2.0 & 2.7 & 2.0 & 2.1 & 1.7 & 2.2 \\
\hline$-\mathbf{N}$ & 2.1 & 2.2 & 1.9 & 1.6 & 1.5 & 2.0 \\
\hline$-\mathbf{P}$ & 1.9 & 2.3 & 2.0 & 2.0 & 1.6 & 2.1 \\
\hline$-K$ & 2.2 & 2.4 & 2.0 & 2.0 & 1.7 & 2.2 \\
\hline -Ca/org & 1.9 & 2.5 & 1.9 & 2.0 & 1.7 & 2.2 \\
\hline$-M g$ & 2.3 & 2.3 & 2.0 & 2.0 & 1.7 & 2.1 \\
\hline$-S$ & 2.0 & 2.2 & 2.2 & 1.9 & 1.6 & 2.1 \\
\hline$-M o /-Z n$ & 2.3 & 2.1 & 2.4 & 2.0 & 1.6 & 2.2 \\
\hline none & 2.2 & 2.3 & 1.9 & 1.9 & 1.9 & 2.2 \\
\hline LSD (0.05) & ns & ns & ns & ns & ns & ns \\
\hline Mean & 2.1 & 2.4 & 2.1 & 2.0 & 1.7 & 2.2 \\
\hline${ }^{\mathrm{a}} \mathbf{L S D}(\mathbf{0 . 0 5})$ & 0.2 & & & & & \\
\hline
\end{tabular}

${ }^{a}$ LSD-test for significant differences of the sampling dates 2-way ANOVA across pooled treatments. 
Table 14: Dynamics of soil C-N-ratio in the $0-30 \mathrm{~cm}$ layer from June 1993 to October 1995 in the minus-one trials. Locations: $\mathrm{CH} 1, \mathrm{CH} 2$.

\begin{tabular}{|c|c|c|c|c|c|c|}
\hline \multicolumn{7}{|c|}{ Sampling date } \\
\hline Treatment & $06 / 93$ & $10 / 93$ & $06 / 94$ & $10 / 94$ & $06 / 95$ & 10/95 \\
\hline \multicolumn{7}{|c|}{ CH 1 (non-degraded) } \\
\hline All & 13.6 & 12.3 & 11.9 & 10.8 & 14.8 & 15.0 \\
\hline All org & 15.1 & 13.0 & 12.1 & 11.5 & 15.0 & 14.6 \\
\hline$-\mathbf{N}$ & 12.7 & 12.4 & 12.4 & 12.0 & 14.8 & 14.8 \\
\hline$-P$ & 12.8 & 12.4 & 13.2 & 11.3 & 13.1 & 15.3 \\
\hline$-\mathbf{K}$ & 13.4 & 12.9 & 12.0 & 11.1 & 14.6 & 15.7 \\
\hline -Ca/org & 14.1 & 12.8 & 12.5 & 11.2 & 13.6 & 14.5 \\
\hline -Mg & 13.0 & 12.8 & 12.2 & 11.6 & 14.5 & 14.2 \\
\hline$-S$ & 13.6 & 12.8 & 13.0 & 11.3 & 14.1 & 14.0 \\
\hline -Mo/-Zn & 12.9 & 12.7 & 12.2 & 11.6 & 14.3 & 14.4 \\
\hline none & 11.3 & 15.2 & 12.7 & 11.8 & 14.4 & 15.1 \\
\hline LSD (0.05) & ns & ns & ns & ns & ns & ns \\
\hline Mean & 13.3 & 12.9 & 12.4 & 11.4 & 14.3 & 14.8 \\
\hline${ }^{\mathrm{a}} \mathbf{L S D}(\mathbf{0 . 0 5})$ & ns & ns & ns & ns & ns & ns \\
\hline \multicolumn{7}{|c|}{$\mathrm{CH} 2$ (degraded) } \\
\hline All & 10.0 & 9.0 & 14.3 & 10.8 & 14.2 & 12.6 \\
\hline All org & 11.0 & 7.2 & 13.0 & 10.6 & 12.6 & 13.0 \\
\hline$-\mathbf{N}$ & 9.7 & 7.9 & 14.6 & 13.1 & 13.7 & 12.3 \\
\hline$-P$ & 11.4 & 8.3 & 12.6 & 10.4 & 13.3 & 12.6 \\
\hline$-\mathbf{K}$ & 10.8 & 8.6 & 13.3 & 10.5 & 13.5 & 14.5 \\
\hline -Ca/org & 11.4 & 7.9 & 13.0 & 10.9 & 13.0 & 13.2 \\
\hline -Mg & 10.4 & 9.3 & 13.6 & 11.0 & 13.4 & 13.1 \\
\hline$-S$ & 11.0 & 8.6 & 13.5 & 12.3 & 13.3 & 12.8 \\
\hline -Mo/-Zn & 9.8 & 10.0 & 13.9 & 10.8 & 13.7 & 12.3 \\
\hline none & 9.6 & 8.5 & 14.4 & 10.9 & 12.2 & 11.0 \\
\hline${ }^{\mathrm{a}} \mathbf{L S D}(\mathbf{0 . 0 5})$ & ns & ns & ns & ns & ns & ns \\
\hline Mean & 10.5 & 8.5 & 13.6 & 11.1 & 13.3 & 12.7 \\
\hline 'at $\mathbf{L} D(\mathbf{0 . 0 5})$ & 0.8 & & & & & \\
\hline
\end{tabular}

${ }^{\mathrm{a}}$ LSD-test for significant differences of the sampling dates 2-way ANOVA across pooled treatments. 
The single sampling dates were evaluated separately by a one-way ANOVA. From June 1993 until the end of the third season in October 1995 there was a substantial build-up of the available $\mathrm{P}$ pool in the soil. After sequential maize cropping for three years with yearly $\mathrm{P}$ fertilizer application, soil available $\mathrm{P}$ content ranged between $21 \mathrm{ppm}$ and $27 \mathrm{ppm}$ at $\mathrm{CH} 1$ and between $13 \mathrm{ppm}$ and $19 \mathrm{ppm}$ at $\mathrm{CH} 2$, as compared with the initial mean values of $8 \mathrm{ppm}$ at $\mathrm{CH} 1$ and $3 \mathrm{ppm}$ at $\mathrm{CH}$ 2. Most of the P applied might be available to crops in subsequent seasons. In contrast, in the (-P) treatment and in the control consecutive maize cropping over three seasons did not change available $\mathrm{P}$ content with time at both sites.

According to the initial soil characterization from June 1993 and from low yield and $\mathrm{P}$ uptake by maize plants in (-P) soils, phosphorus was identified to be the second most limiting nutrient for plant production in the study soils. Unamended soils supply insufficient plant available $\mathrm{P}$ to reach grain yields of more than one $\mathrm{tha}^{-1}$, and require P fertilization to increase crop production.

Continuous mineral P application to maize steadily increased the plant available $\mathrm{P}$ pool in the study soils. This indicates a low P-sorption capacity of the two soils and subsequent crops might benefit from residual effects. Several authors also described a sustained residual effect of inorganic P applied to Alfisols in south-western Nigeria (JUO and FOX, 1977; OYOVBISERE and LOMBIN, 1991; WICK, 1997). The results presented above were in line with results presented by KANG and OSIMANE (1979) as cited by WICK (1997), who reported that low rates of fertilization $\left(26 \mathrm{~kg} \mathrm{P} \mathrm{ha}^{-1}\right)$ led to a substantial build-up of available $\mathrm{P}$ and the residual effect of the applied $\mathrm{P}$ was still observed after 4 cropping cycles.

In contrast, ABEKOE and TIESSEN (1998) reported that lateritic soils from semi-arid northern Ghana are not only inherently low in plant available P. They are also characterized by phosphorus sorption and low mobility of $\mathrm{P}$ at field capacity resulting in low $\mathrm{P}$ supplying ability. Owusu-BenNoAh et al. (1991) and ABEKoE and TIESSEN (1998) reported that the lateritic concretions act as a sink for fertilizer $\mathrm{P}$ but, also may be a potential reservoir of available P. Although, most of the soils studied from northern Ghana have low to moderate P sorption capacities (TIESSEN et al., 1991), lateritic nodules sorb increasing amounts of $\mathrm{P}$ upon extended contact, which limits agronomic effectiveness of $\mathrm{P}$ fertilizers in these soils (ABEKOE \& TIESSEN, 1998). 
Table 15: Dynamics of soil Bray-I P content (ppm) in the 0 - $30 \mathrm{~cm}$ layer from June 1993 to October 1995 in the minus-one trials. Locations: $\mathrm{CH} 1$ and $\mathrm{CH} 2$.

\begin{tabular}{|c|c|c|c|c|c|c|}
\hline \multirow[b]{2}{*}{ Treatment } & \multicolumn{6}{|c|}{ Sampling date } \\
\hline & $06 / 93$ & $10 / 93$ & $06 / 94$ & $10 / 94$ & $06 / 95$ & $10 / 95$ \\
\hline \multicolumn{7}{|c|}{ CH 1 (non-degraded) } \\
\hline All & 7 & 18 & 21 & 14 & 25 & 24 \\
\hline All org & 6 & 17 & 9 & 17 & 16 & 23 \\
\hline$-\mathrm{N}$ & 8 & 38 & 15 & 27 & 16 & 27 \\
\hline$-\mathbf{P}$ & 8 & 9 & 8 & 7 & 9 & 7 \\
\hline$-K$ & 7 & 16 & 11 & 19 & 11 & 21 \\
\hline -Ca/org & 6 & 14 & 9 & 10 & 9 & 10 \\
\hline$-\mathrm{Mg}$ & 10 & 20 & 15 & 24 & 21 & 24 \\
\hline$-S$ & 6 & 21 & 12 & 16 & 20 & 21 \\
\hline$-\mathrm{Mo} /-\mathbf{Z n}$ & 13 & 19 & 15 & 27 & 22 & 23 \\
\hline none & 9 & 10 & 8 & 9 & 8 & 7 \\
\hline LSD (0.05) & ns & ns & ns & 14 & 10 & 12 \\
\hline Mean & 8 & 18 & 12 & 17 & 16 & 19 \\
\hline \multirow[t]{2}{*}{${ }^{\mathrm{a}} \mathbf{L S D}(\mathbf{0 . 0 5})$} & 4 & & & & & \\
\hline & \multicolumn{6}{|c|}{$\mathrm{CH} 2$ (degraded) } \\
\hline All & 3 & 8 & 6 & 17 & 21 & 19 \\
\hline All org & 3 & 8 & 7 & 15 & 14 & 16 \\
\hline$-\mathrm{N}$ & 3 & 10 & 12 & 30 & 30 & 17 \\
\hline$-P$ & 3 & 4 & 4 & 3 & 3 & 3 \\
\hline$-\mathbf{K}$ & 3 & 10 & 8 & 20 & 18 & 19 \\
\hline -Ca/org & 3 & 8 & 7 & 6 & 6 & 5 \\
\hline$-M g$ & 3 & 13 & 8 & 17 & 15 & 15 \\
\hline$-S$ & 3 & 9 & 7 & 48 & 13 & 13 \\
\hline -Mo/-Zn & 3 & 11 & 8 & 22 & 38 & 17 \\
\hline none & 3 & 3 & 4 & 3 & 3 & 3 \\
\hline LSD (0.05) & ns & 5 & 3 & 21 & 19 & 6 \\
\hline Mean & 3 & 8 & 7 & 18 & 16 & 13 \\
\hline${ }^{\mathrm{a}} \mathbf{L S D}$ (0.05) & 4 & & & & & \\
\hline \multicolumn{7}{|c|}{ Interaction: treatment $\mathbf{x}$ date ${ }^{* * *}$} \\
\hline${ }^{\mathrm{b}} \mathrm{LSD}(0.05)$ & 12 & & & & & \\
\hline
\end{tabular}

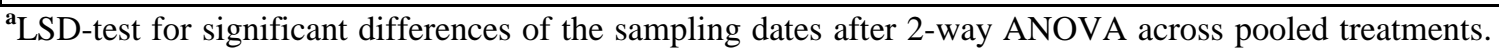

${ }^{\mathbf{b}}$ LSD-test for significant interaction between sampling date and treatment after a 2-way ANOVA. 


\subsubsection{Soil organic phosphorus}

Site variability in the study fields usually was large (CV > $20 \%)$ for soil organic P content. The two sites differed in their initial organic P content with $162 \mathrm{ppm}$ at the non-degraded $\mathrm{CH} 1$ site and $84 \mathrm{ppm}$ at the degraded CH 2 site. Differences between treatments were not significant. Yearly inorganic $\mathrm{P}$ application $\left(60 \mathrm{~kg} \mathrm{P} \mathrm{ha}^{-1}\right)$ increased soil organic $\mathrm{P}$ in the top 0 - $30 \mathrm{~cm}$ layer with time from June 1993 to October 1995 (Table 16). At CH 1, organic P increased from $162 \mathrm{ppm}$ to $185 \mathrm{ppm}(14 \%)$. At the degraded $\mathrm{CH} 2$ site, organic $\mathrm{P}$ increased from $84 \mathrm{ppm}$ to $93 \mathrm{ppm}(11 \%)$. Sequential maize cropping led to an increase in organic $\mathrm{P}$ in the (-P) treatment at $\mathrm{CH} 1(27 \%)$ and at $\mathrm{CH} 2(8 \%)$, probably due to the crop residues which were left in the fields.

Several studies have shown the importance of soil organic $\mathrm{P}$ mineralization in providing available P in temperate (HEDLEY et al., 1982; TIESSEN et al., 1983; STEWART and TIESSEN, 1987) and tropical zones (TIESSEN et al., 1992; BALL-COELHO et al, 1993). Similar results for organic P mineralization and a decreasing organic P pool were reported by several authors (TIESSEN et al., 1992; WICK, 1997). In contrast to our results, in savanna soils in semi-arid northeastern Brazil six years of cultivation with minimal fertilization resulted in reductions of organic $\mathrm{P}$ by $30 \%$ and available $\mathrm{P}$ was greatly reduced under these conditions (TIESSEN et al., 1992).

The organic P pool has been regarded as an indicator of the P supplying capacity of soils. It represents overall changes in SOM by functioning as a source and sink of $\mathrm{P}$ in cultivated soils (STEWART and TIESSEN, 1987; TIESSEN et al., 1992, 1994; BECK and SANCHEZ, 1994). Yearly inorganic $\mathrm{P}$ fertilization increased short-term $\mathrm{P}$ fertility and at the same time contributed to maintain the organic $\mathrm{P}$ pool. These results are in agreement with investigations by BECK and SANCHEZ (1994) and PANIAGUA et al. (1995). A decline in organic $\mathrm{P}$ levels was found under non-fertilized but mulched plots when compared to fertilized treatments (PANIAGUA et al., 1995). Both authors concluded that inorganic $\mathrm{P}$ fertilization rather than organic additions regulated the size of organic $\mathrm{P}$ accumulation. 
Table 16: Dynamics of soil organic P content in the $0-30 \mathrm{~cm}$ layer (ppm) from June 1993 to October 1995 in the minus-one trials. Locations: $\mathrm{CH} 1$ and $\mathrm{CH} 2$.

\begin{tabular}{|c|c|c|c|c|c|c|}
\hline \multirow[b]{2}{*}{ Treatment } & \multicolumn{6}{|c|}{ Sampling date } \\
\hline & $06 / 93$ & $10 / 93$ & $06 / 94$ & $10 / 94$ & $06 / 95$ & $10 / 95$ \\
\hline \multicolumn{7}{|c|}{ CH 1 (non-degraded) } \\
\hline All & 162 & 187 & 150 & 177 & 192 & 186 \\
\hline All org & 153 & 157 & 137 & 181 & 169 & 168 \\
\hline$-\mathbf{N}$ & 167 & 172 & 136 & 180 & 176 & 188 \\
\hline$-\mathbf{P}$ & 175 & 183 & 148 & 201 & 190 & 223 \\
\hline$-K$ & 166 & 176 & 133 & 191 & 206 & 186 \\
\hline -Ca/org & 161 & 154 & 130 & 187 & 174 & 192 \\
\hline -Mg & 172 & 169 & 129 & 192 & 184 & 181 \\
\hline$-S$ & 144 & 145 & 123 & 157 & 151 & 178 \\
\hline -Mo/-Zn & 155 & 144 & 118 & 151 & 168 & 191 \\
\hline none & 165 & 138 & 124 & 161 & 168 & 157 \\
\hline LSD (0.05) & ns & ns & ns & ns & ns & ns \\
\hline Mean & 162 & 162 & 133 & 178 & 178 & 185 \\
\hline 'LSD (0.05) & 13 & & & & & \\
\hline \multicolumn{7}{|c|}{ CH 2 (degraded) } \\
\hline All & 86 & 71 & 79 & 87 & 95 & 103 \\
\hline All org & 94 & 78 & 65 & 88 & 81 & 105 \\
\hline$-\mathbf{N}$ & 76 & 68 & 61 & 67 & 66 & 75 \\
\hline$-\mathbf{P}$ & 84 & 80 & 63 & 84 & 68 & 91 \\
\hline$-\mathbf{K}$ & 86 & 67 & 61 & 83 & 81 & 101 \\
\hline -Ca/org & 68 & 64 & 58 & 71 & 72 & 90 \\
\hline -Mg & 87 & 76 & 75 & 84 & 83 & 98 \\
\hline$-S$ & 84 & 61 & 60 & 62 & 82 & 96 \\
\hline -Mo/-Zn & 92 & 82 & 71 & 80 & 84 & 87 \\
\hline none & 85 & 70 & 68 & 76 & 67 & 84 \\
\hline LSD (0.05) & ns & ns & ns & ns & ns & ns \\
\hline Mean & 84 & 72 & 66 & 78 & 78 & 93 \\
\hline${ }^{\mathrm{a}} \mathbf{L S D}(\mathbf{0 . 0 5})$ & 8 & & & & & \\
\hline
\end{tabular}

${ }^{\text {a }}$ LSD-test for significant differences of the sampling dates after 2-way ANOVA across pooled treatments. 


\subsubsection{Base saturation and effective soil cation exchange capacity (CEC)}

Initial base saturation did not differ between sites (Annex, Table 51). On average across treatments, soil base saturation decreased with time at both sites. Comparing the two fields the loss of bases with time was much stronger at the degraded $\mathrm{CH} 2$ site than at the $\mathrm{CH} 1$ site. The lowest decline was found in the $(-\mathrm{N})$ and in the control treatments. These observations are consistent with the small decrease in soil $\mathrm{pH}$ in the (-N) and the control treatment. This is indicating a low buffer capacity. Even extensive maize cropping without fertilizer use will depress soil $\mathrm{pH}$ and contribute to loss of bases.

Effective soil cation exchange capacity (CEC) remained lower at $\mathrm{CH} 2$ throughout the experiment for all treatments (Table 17). Except for October 1995 at the $\mathrm{CH} 2$ site, no significant differences were observed between treatments. Averaged across treatments, CEC varied significantly with time. Across experimental years the use of cotton seed waste had a positive effect on CEC in both soils. The results also reveal that a balanced mineral fertilization was able to maintain the status of CEC at the $\mathrm{CH} 1$ site or even to increase $\mathrm{CEC}$ at the degraded $\mathrm{CH} 2$ site. These effects could be due to higher plant biomass residues in the fertilized plots and due to application of cotton seed waste.

Cation exchange capacity is dependent on type of the clay and quality of organic matter. The SOM normally makes a substantial contribution to the CEC, particularly in soils that are low in clay. Especially, on low-activity kaolinitic clay soils, SOM provides exchange and retention capacity for soil nutrients. The importance of SOM in terms of cation storage in savanna soils is reflected by high correlation of SOM with CEC (Annex, Table 54).

\subsubsection{Exchangeable $\mathrm{K}$}

The study sites differed substantially in their exchangeable $\mathrm{K}$ content with much higher values at $\mathrm{CH} 1$ (Table 18). Differences between sites were not compensated for by yearly $\mathrm{K}$ fertilizer applications. Fluctuations in exchangeable K were significantly influenced by treatments and sampling dates. As indicated by the two-way ANOVA the interaction between treatment and sampling date was highly significant in both fields.

In all treatments which had received K fertilizer, exchangeable K increased from June 1993 to October 1995. There was a greater build-up of the exchangeable K pool in the degraded CH 2 soil. 
Table 17: Dynamics of CEC $\left(\mathrm{cmol}^{+} \mathrm{kg}^{-1}\right)$ in the $0-30 \mathrm{~cm}$ soil layer from June 1993 to October 1995 in the minus-one trials. Locations: $\mathrm{CH} 1, \mathrm{CH} 2$.

\begin{tabular}{|c|c|c|c|c|c|c|}
\hline \multicolumn{7}{|c|}{ Sampling date } \\
\hline Treatment & $06 / 93$ & $10 / 93$ & $06 / 94$ & $10 / 94$ & $06 / 95$ & $10 / 95$ \\
\hline \multicolumn{7}{|c|}{ CH 1 (non-degraded) } \\
\hline All & 5.9 & 5.9 & 6.8 & 6.4 & 6.9 & 6.3 \\
\hline All org & 6.0 & 6.6 & 7.4 & 6.5 & 7.6 & 6.7 \\
\hline$-\mathbf{N}$ & 6.7 & 6.3 & 7.1 & 6.7 & 7.1 & 5.6 \\
\hline$-\mathbf{P}$ & 7.0 & 7.0 & 8.2 & 7.1 & 7.6 & 6.7 \\
\hline$-K$ & 6.8 & 6.3 & 7.6 & 6.8 & 7.3 & 6.4 \\
\hline -Ca/org & 6.4 & 5.9 & 7.5 & 6.9 & 6.8 & 6.4 \\
\hline -Mg & 7.2 & 6.7 & 7.7 & 7.8 & 7.6 & 6.7 \\
\hline$-S$ & 6.9 & 6.8 & 7.5 & 7.2 & 9.0 & 6.9 \\
\hline -Mo/-Zn & 6.9 & 6.3 & 7.3 & 7.4 & 7.5 & 6.3 \\
\hline none & 6.9 & 6.3 & 7.6 & 6.8 & 6.8 & 5.8 \\
\hline LSD (0.05) & ns & ns & ns & ns & ns & ns \\
\hline Mean & 6.7 & 6.4 & 7.5 & 7.0 & 7.4 & 6.4 \\
\hline${ }^{\mathrm{a}} \operatorname{LSD}(\mathbf{0 . 0 5})$ & 0.5 & & & & & \\
\hline \multicolumn{7}{|c|}{ CH 2 (degraded) } \\
\hline All & 3.1 & 4.2 & 4.8 & 4.9 & 4.1 & 3.7 \\
\hline All org & 3.2 & 4.1 & 4.4 & 4.3 & 3.6 & 4.1 \\
\hline$-\mathbf{N}$ & 4.1 & 3.5 & 4.2 & 4.2 & 3.3 & 3.2 \\
\hline$-\mathbf{P}$ & 4.5 & 3.8 & 4.2 & 4.2 & 3.6 & 3.5 \\
\hline$-K$ & 4.4 & 3.8 & 4.4 & 4.3 & 3.4 & 3.7 \\
\hline -Ca/org & 3.1 & 3.8 & 4.4 & 3.8 & 3.5 & 3.7 \\
\hline -Mg & 3.3 & 4.3 & 4.8 & 4.6 & 3.5 & 3.9 \\
\hline$-S$ & 3.1 & 3.6 & 4.5 & 4.4 & 3.5 & 3.9 \\
\hline -Mo/-Zn & 3.4 & 3.8 & 4.5 & 4.5 & 3.6 & 3.7 \\
\hline none & 3.2 & 3.7 & 4.3 & 4.1 & 3.2 & 3.1 \\
\hline LSD (0.05) & ns & ns & ns & ns & ns & $0.5 *$ \\
\hline Mean & 3.5 & 3.9 & 4.5 & 4.3 & 3.5 & 3.6 \\
\hline${ }^{a} \operatorname{LSD}(\mathbf{0 . 0 5})$ & 0.3 & & & & & \\
\hline
\end{tabular}

${ }^{a}$ LSD-test for significant differences of the sampling dates after 2-way ANOVA across pooled treatments. 
At $\mathrm{CH} 2$, exchangeable $\mathrm{K}$ also increased in the (-K) plots and in the control in the second year and was still at a relatively high level at the beginning of the third season. This might be either due to mobilization (release) of exchangeable $\mathrm{K}$ in the soil and/or mineralization of crop residues, which were mainly consisting of maize straw with high amounts of $\mathrm{K}$ in the plant biomass. However, this was only a temporary effect and in the third season exchangeable K decreased until October 1995.

As compared to the initial status, in the $(-\mathrm{K})$ plots and in the control exchangeable $\mathrm{K}$ was significantly reduced at the end of the third season (October 1995) at both sites; a much higher loss of exchangeable $\mathrm{K}$ was found in the non-degraded $\mathrm{CH} 1$ soil. These highly significant reductions in the $(-\mathrm{K})$ treatment $(49 \%)$ and in the control $(34 \%)$ clearly indicate that soil exchangeable $\mathrm{K}$ was progressively depleted. At $\mathrm{CH} 2$, the decrease in exchangeable $\mathrm{K}$ ranged from $49 \%$ in the $(-\mathrm{K})$ treatment to $3 \%$ in the control.

These findings suggest that the $\mathrm{K}$ supplying power was severely reduced at $\mathrm{CH} 2$. The results are also indicating how susceptible a cropped savanna soil is to K degradation, both in a situation of relatively high yields which were achieved in the (-K) and relative low yields in the control treatments. WILD (1971) as cited by RHODES (1988) already concluded that $\mathrm{K}$ deficiency will occur commonly in the field with intensive cropping on low CEC savanna soils. It has been reported (RHODES, 1988) that cultivation of Typic Paleudults, following land clearing and burning, resulted in a decline in exchangeable $\mathrm{K}$ of $-62 \%$ to $-72 \%$ in 2 to 3 years of cropping without fertilizers.

The relatively high accumulation of exchangeable $\mathrm{K}$ due to annual fertilizer application indicates that $\mathrm{K}$ leaching was low and the fertilization dose well above plant demand. In soils in southern Togo, $\mathrm{K}$ leaching below $180 \mathrm{~cm}$ was about the same as $\mathrm{K}$ added through rainfall and was thus negligible compared to K added (Poss et al., 1997). These results agree with published data dealing with the cultivation of various crops in western Africa where $\mathrm{K}$ fertilization was between 30 and $50 \mathrm{~kg} \mathrm{~K} \mathrm{ha}{ }^{-1} \mathrm{yr}^{-1}$. Potassium leaching is usually less than $10 \%$ of K applied (VAN DER POL and TRAORE, 1993; WONG et al., 1993 all authors as cited by Poss et al., 1997).

In conclusion, nutrient replacement fertilization based on nutrient removal by crop yields should be the farmers' general practice in order to avoid a decline in exchangeable $\mathrm{K}$ status. 
Table 18: Dynamics of exchangeable $\mathrm{K}\left(\mathrm{cmol}^{+} \mathrm{kg}^{-1}\right)$ in the $0-30 \mathrm{~cm}$ soil layer from June 1993 to October 1995 in the minus-one trials. Locations: CH 1, CH 2.

\begin{tabular}{|c|c|c|c|c|c|c|}
\hline \multirow[b]{2}{*}{ Treatment } & \multicolumn{6}{|c|}{ Sampling date } \\
\hline & $06 / 93$ & $10 / 93$ & $06 / 94$ & $10 / 94$ & $06 / 95$ & $10 / 95$ \\
\hline \multicolumn{7}{|c|}{ CH 1 (non-degraded) } \\
\hline All & 0.15 & 0.20 & 0.23 & 0.51 & 0.59 & 0.72 \\
\hline All org & 0.17 & 0.26 & 0.24 & 0.54 & 0.70 & 0.70 \\
\hline$-\mathbf{N}$ & 0.16 & 0.23 & 0.22 & 0.61 & 0.62 & 0.66 \\
\hline$-P$ & 0.17 & 0.23 & 0.25 & 0.59 & 0.72 & 0.62 \\
\hline$-K$ & 0.19 & 0.20 & 0.21 & 0.08 & 0.09 & 0.10 \\
\hline -Ca/org & 0.17 & 0.23 & 0.20 & 0.56 & 0.61 & 0.71 \\
\hline$-\mathrm{Mg}$ & 0.16 & 0.22 & 0.24 & 0.56 & 0.55 & 0.70 \\
\hline$-S$ & 0.16 & 0.21 & 0.22 & 0.50 & 0.68 & 0.65 \\
\hline -Mo/-Zn & 0.17 & 0.20 & 0.22 & 0.52 & 0.59 & 0.62 \\
\hline none & 0.17 & 0.22 & 0.21 & 0.09 & 0.11 & 0.11 \\
\hline LSD $(0.05)$ & ns & ns & ns & 0.12 & 0.15 & 0.23 \\
\hline Mean & 0.17 & 0.22 & 0.22 & 0.46 & 0.52 & 0.56 \\
\hline${ }^{\mathrm{a}} \mathbf{L S D}(\mathbf{0 . 0 5})$ & 0.04 & & & & & \\
\hline \multicolumn{7}{|c|}{ Interaction: treatment $\mathbf{x}$ date $* * *$} \\
\hline \multirow[t]{2}{*}{${ }^{\mathrm{b}} \mathrm{LSD}(0.05)$} & 0.07 & & & & & \\
\hline & \multicolumn{6}{|c|}{$\mathrm{CH} 2$ (degraded) } \\
\hline All & 0.07 & 0.16 & 0.21 & 0.43 & 0.39 & 0.41 \\
\hline All org & 0.08 & 0.13 & 0.27 & 0.39 & 0.38 & 0.43 \\
\hline$-N$ & 0.08 & 0.14 & 0.23 & 0.45 & 0.35 & 0.45 \\
\hline -P & 0.06 & 0.14 & 0.34 & 0.42 & 0.39 & 0.47 \\
\hline$-\mathbf{K}$ & 0.07 & 0.09 & 0.22 & 0.20 & 0.19 & 0.05 \\
\hline -Ca/org & 0.07 & 0.12 & 0.24 & 0.28 & 0.31 & 0.36 \\
\hline$-\mathrm{Mg}$ & 0.07 & 0.13 & 0.29 & 0.37 & 0.35 & 0.40 \\
\hline$-S$ & 0.09 & 0.13 & 0.26 & 0.38 & 0.31 & 0.39 \\
\hline -Mo/-Zn & 0.07 & 0.14 & 0.29 & 0.35 & 0.30 & 0.38 \\
\hline none & 0.06 & 0.09 & 0.20 & 0.20 & 0.21 & 0.06 \\
\hline LSD (0.05) & ns & 0.04 & $0.09^{c}$ & 0.09 & 0.10 & 0.07 \\
\hline Mean & 0.07 & 0.13 & 0.25 & 0.35 & 0.32 & 0.34 \\
\hline${ }^{\mathrm{a}} \mathbf{L S D}(\mathbf{0 . 0 5})$ & 0.02 & & & & & \\
\hline \multicolumn{7}{|c|}{ Interaction: treatment $\mathbf{x}$ date $* * *$} \\
\hline${ }^{\mathrm{b}} \mathbf{L S D}(\mathbf{0 . 0 5})$ & 0.07 & & & & & \\
\hline
\end{tabular}

${ }^{\mathrm{a}} \mathrm{LSD}$-test for significant differences of the sampling dates after 2-way ANOVA across pooled treatments. ${ }^{\mathrm{b}}$ LSD-test for significant interaction between sampling date and treatment after a 2-way ANOVA.

${ }^{\mathrm{c}} \mathrm{F}$-test for significant differences of treatments after a 1-way ANOVA was only significant at the $6 \%$ level. 


\subsubsection{Exchangeable $\mathrm{Ca}$ and $\mathrm{Mg}$}

According to the initial soil characterization, $\mathrm{Ca}$ and $\mathrm{Mg}$ were the dominant cations on the exchange complex (Table 7). Soil exchangeable $\mathrm{Ca}$ and $\mathrm{Mg}$ content were substantially lower at the degraded $\mathrm{CH} 2$ site during the experiment. Across treatments, exchangeable $\mathrm{Ca}$ content declined significantly with time during three years of consecutive maize cropping (Table 19). No differences were observed among treatments. Calcium depletion was much stronger at $\mathrm{CH} 2$ as compared to the non-degraded $\mathrm{CH} 1$ site. Average $\mathrm{Ca}$ loss across all treatments was $42 \%$ at $\mathrm{CH} 1$ and $57 \%$ at $\mathrm{CH} 2$.

Exchangeable $\mathrm{Mg}$ content tended to increase with time due to annual $\mathrm{Mg}$ fertilization (Table 20). No differences were observed between treatments at each individual sampling date at the non-degraded $\mathrm{CH} 1$ site. In contrast, significant treatment effects could be observed in the degraded $\mathrm{CH} 2$ soil after the second and third year of maize cropping. Soil exchangeable $\mathrm{Mg}$ content was significantly lower in the control and (-Mg) treatment relative to the complete fertilized treatments (All).

\subsubsection{Extractable sulfate-S and exchangeable manganese}

At the beginning of the experiments the soils differed substantially in their extractable sulfate-S and exchangeable $\mathrm{Mn}$ and $\mathrm{Zn}$ content. The $\mathrm{CH} 1$ site was characterized by much higher sulfate $(1.8 \mathrm{ppm})$ and $\mathrm{Zn}(1.2 \mathrm{ppm})$ but lower Mn (0.04 ppm) content than the CH 2 site with 1.4 ppm sulfate-S, 0.4 ppm Zn and 0.08 Mn.

Across treatments, sulfate-S fluctuated significantly over time at both sites. There was no visible trend with regard to the different treatments. No significant differences were found in both soils among treatments at any sampling date (Annex, Table 52).

In all experimental plots soil exchangeable $\mathrm{Zn}$ content increased strongly in the first year due to the application of mineral $\mathrm{Zn}$. Therefore, it is concluded that $5 \mathrm{~kg} \mathrm{Zn} \mathrm{ha}^{-1}$ is enough to avoid Zn deficiency in the soil.

Soil exchangeable manganese fluctuated significantly with time and tended to increase at $\mathrm{CH} 1$ probably due to acidification by urea fertilization (Annex, Table 53). In the degraded CH 2 soil, exchangeable Mn remained nearly unchanged among sampling dates and treatments. 
Table 19: Dynamics of exchangeable Ca $\left(\mathrm{cmol}^{+} \mathrm{kg}^{-1}\right)$ in the $0-30 \mathrm{~cm}$ soil layer from June 1993 to October 1995 in the minus-one trials. Locations: $\mathrm{CH} 1, \mathrm{CH} 2$.

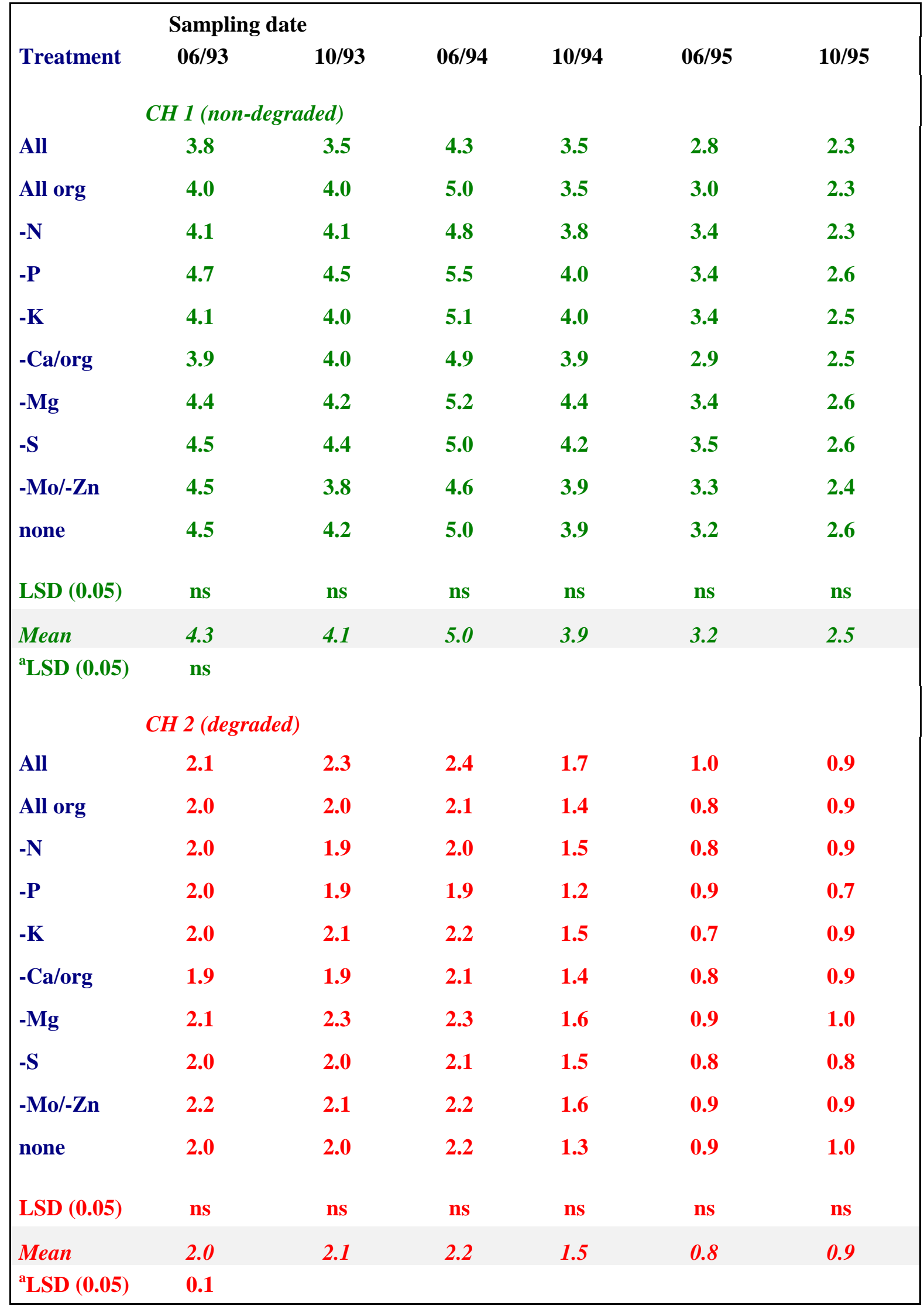

${ }^{\mathrm{a}}$ LSD-test for significant differences of the sampling dates after 2-way ANOVA across pooled treatments. 
Table 20: Dynamics of exchangeable $\mathrm{Mg}\left(\mathrm{cmol}^{+} \mathrm{kg}^{-1}\right)$ in the $0-30 \mathrm{~cm}$ soil layer from June 1993 to October 1995 in the minus-one trials. Locations: CH 1, CH 2.

\begin{tabular}{|c|c|c|c|c|c|c|}
\hline \multicolumn{7}{|c|}{ Sampling date } \\
\hline Treatment & $06 / 93$ & $10 / 93$ & $06 / 94$ & $10 / 94$ & $06 / 95$ & $10 / 95$ \\
\hline \multicolumn{7}{|c|}{ CH 1 (non-degraded) } \\
\hline All & 0.95 & 0.86 & 0.84 & 0.85 & 0.91 & 1.28 \\
\hline All org & 1.02 & 1.00 & 0.98 & 0.83 & 1.14 & 1.36 \\
\hline$-\mathbf{N}$ & 1.01 & 0.95 & 0.88 & 0.89 & 0.92 & 1.24 \\
\hline -P & 1.08 & 1.01 & 1.00 & 0.89 & 0.97 & 1.34 \\
\hline -K & 1.06 & 0.99 & 0.97 & 0.93 & 1.13 & 1.46 \\
\hline -Ca/org & 1.09 & 1.01 & 1.00 & 0.96 & 0.86 & 1.23 \\
\hline -Mg & 1.10 & 0.95 & 0.94 & 0.90 & 0.95 & 1.23 \\
\hline$-S$ & 1.13 & 1.02 & 0.99 & 0.94 & 1.07 & 1.39 \\
\hline -Mo/-Zn & 1.08 & 0.90 & 0.86 & 0.91 & 0.95 & 1.25 \\
\hline none & 1.04 & 0.93 & 0.90 & 0.83 & 0.89 & 1.24 \\
\hline LSD (0.05) & ns & ns & ns & ns & ns & ns \\
\hline Mean & 1.06 & 0.96 & 0.94 & 0.89 & 0.98 & 1.30 \\
\hline${ }^{\mathrm{a}} \mathbf{L S D}(\mathbf{0 . 0 5})$ & 0.1 & & & & & \\
\hline \multicolumn{7}{|c|}{ CH 2 (degraded) } \\
\hline All & 0.51 & 0.55 & 0.59 & 0.55 & 0.83 & 0.79 \\
\hline All org & 0.48 & 0.48 & 0.53 & 0.50 & 0.76 & 0.75 \\
\hline$-\mathbf{N}$ & 0.46 & 0.46 & 0.51 & 0.48 & 0.69 & 0.74 \\
\hline$-\mathbf{P}$ & 0.44 & 0.41 & 0.43 & 0.42 & 0.63 & 0.57 \\
\hline$-K$ & 0.48 & 0.48 & 0.54 & 0.50 & 0.73 & 0.82 \\
\hline -Ca/org & 0.46 & 0.45 & 0.51 & 0.43 & 0.69 & 0.69 \\
\hline -Mg & 0.53 & 0.46 & 0.50 & 0.42 & 0.69 & 0.60 \\
\hline$-S$ & 0.50 & 0.48 & 0.51 & 0.46 & 0.70 & 0.68 \\
\hline -Mo/-Zn & 0.53 & 0.50 & 0.53 & 0.48 & 0.75 & 0.74 \\
\hline none & 0.47 & 0.46 & 0.50 & 0.40 & 0.60 & 0.69 \\
\hline LSD (0.05) & ns & ns & ns & 0.02 & ns & 0.04 \\
\hline Mean & 0.50 & 0.47 & 0.52 & 0.46 & 0.71 & 0.71 \\
\hline${ }^{\mathrm{a}} \operatorname{LSD}(\mathbf{0 . 0 5})$ & 0.03 & & & & & \\
\hline
\end{tabular}

${ }^{a}$ LSD-test for significant differences of the sampling dates after 2-way ANOVA across pooled treatments. 


\subsection{Dynamics of soil microbiological characteristics}

\subsubsection{Soil microbial biomass}

As reported in chapter 5.1.1 the initial values of soil microbial $\mathrm{C}\left(\mathrm{C}_{\mathrm{mic}}\right)$ content were significantly smaller at the degraded CH 2 site in June 1993 (Table 8). A two-way ANOVA revealed only sampling date to have a significant influence on $\mathrm{C}_{\mathrm{mic}}$ at both locations indicating that seasonal effects were much greater than treatment effects (Table 21).

Seasonal variability within the experimental years was generally higher at the non-degraded $\mathrm{CH} 1$ site than at the highly degraded $\mathrm{CH} 2$ site. At both sites, $\mathrm{C}_{\text {mic }}$ was always smaller at the beginning of the season than at the end of the cropping period. Within the first season, in the top soil $\mathrm{C}_{\text {mic }}$ increased most strongly, on average across treatments by $118 \%$ at $\mathrm{CH} 1$ and by $52 \%$ at $\mathrm{CH} 2$.

The one-way ANOVA revealed significant treatment effects only at the degraded $\mathrm{CH} 2$ site. Here, at the end of the first cropping season in October 1993, $\mathrm{C}_{\text {mic }}$ was highest in the amended treatments (All, All org) than in the treatments (-N), (-P), (-K), (-Ca) and in the control. In the $(-\mathrm{N}),(-\mathrm{P})$, and $(-\mathrm{K})$ treatments $\mathrm{C}_{\text {mic }}$ remained nearly unchanged and decreased strongly in the control from June to October 1993. In 1994, at the degraded CH 2 site, treatment effects were not significant. At the beginning of the third season in June $1995, \mathrm{C}_{\text {mic }}$ was significantly lower in the (-N) and (-P) treatments and highest after mineral fertilization (All) or where cotton seed waste was applied, either alone (org) or in addition to mineral fertilizer (All org) during the previous two experimental years. In October 1995, after three consecutive cropping years, $\mathrm{C}_{\text {mic }}$ was significantly lower without $\mathrm{N}, \mathrm{P}, \mathrm{K}, \mathrm{Mg}, \mathrm{S}$ and $\mathrm{Mo} / \mathrm{Zn}$ application and in the control as compared to completely mineral (All), organically (org) and combined (All org) fertilized plots. The maximum $\mathrm{C}_{\text {mic }}$ values were recorded after fertilizer application plus additional cotton seed waste (All org).

The formation of higher soil microbial biomass in the first year might be stimulated on the turnover of aboveground plant biomass and root-derived material at this site. When side selection was done, it was visible from the above ground fallow vegetation that $\mathrm{CH} 1$ produced higher plant biomass. The higher productivity potential was confirmed by maize yields of the control at the end of the first year (Table 9 and 10). The more productive $\mathrm{CH} 1$ site, with a larger above ground fallow vegetation, probably also had a larger rooting density at the beginning of the experiments which might have increased the labile $\mathrm{C}$ supply. 
Table 21: Dynamics of soil microbial biomass carbon content $\left(\mu \mathrm{g} \mathrm{C} \mathrm{g}^{-1}\right.$ soil) in the $0-30$ cm soil layer from June 1993 to October 1995. Locations: CH 1, CH 2.

\begin{tabular}{|c|c|c|c|c|c|c|}
\hline \multicolumn{7}{|c|}{ Sampling date } \\
\hline Treatment & $06 / 93$ & $10 / 93$ & $06 / 94$ & $10 / 94$ & $06 / 95$ & $10 / 95$ \\
\hline \multicolumn{7}{|c|}{ CH 1 (non-degraded) } \\
\hline All & 41 & 130 & 154 & 140 & 77 & 131 \\
\hline All org & 63 & 121 & 144 & 144 & 70 & 137 \\
\hline$-\mathbf{N}$ & 73 & 116 & 97 & 118 & 57 & 88 \\
\hline$-\mathbf{P}$ & 51 & 125 & 107 & 106 & 67 & 112 \\
\hline$-\mathbf{K}$ & 52 & 135 & 101 & 120 & 71 & 121 \\
\hline -Ca/org & 56 & 122 & 99 & 146 & 69 & 133 \\
\hline -Mg & 79 & 133 & 115 & 131 & 73 & 129 \\
\hline$-S$ & 62 & 134 & 117 & 136 & 72 & 120 \\
\hline -Mo/-Zn & 47 & 130 & 95 & 129 & 74 & 119 \\
\hline none & 59 & 124 & 103 & 125 & 50 & 90 \\
\hline LSD (0.05) & ns & ns & ns & ns & ns & ns \\
\hline Mean & 58 & 127 & 113 & 130 & 68 & 118 \\
\hline${ }^{\mathrm{a}} \mathbf{L S D}(\mathbf{0 . 0 5})$ & 11.0 & & & & & \\
\hline \multicolumn{7}{|c|}{ CH 2 (degraded) } \\
\hline All & 30 & 95 & 57 & 66 & 61 & 65 \\
\hline All org & 43 & 104 & 56 & 71 & 62 & 83 \\
\hline$-\mathbf{N}$ & 26 & 49 & 32 & 31 & 34 & 37 \\
\hline$-\mathbf{P}$ & 37 & 36 & 23 & 46 & 38 & 36 \\
\hline$-\mathbf{K}$ & 45 & 43 & 45 & 57 & 46 & 50 \\
\hline -Ca/org & 41 & 51 & 56 & 78 & 65 & 69 \\
\hline -Mg & 22 & 69 & 48 & 46 & 47 & 35 \\
\hline$-S$ & 45 & 75 & 64 & 65 & 57 & 49 \\
\hline$-M o /-Z n$ & 64 & 64 & 43 & 64 & 40 & 52 \\
\hline none & 53 & 28 & 38 & 29 & 39 & 33 \\
\hline LSD (0.05) & ns & 41 & $29^{b}$ & ns & 22 & 2 \\
\hline Mean & 41 & 61 & 46 & 55 & 49 & 51 \\
\hline${ }^{\mathrm{a}} \mathbf{L S D}(\mathbf{0 . 0 5})$ & 12.0 & & & & & \\
\hline
\end{tabular}

${ }^{a}$ LSD-test for significant differences of the sampling dates after 2-way ANOVA across pooled treatments.

${ }^{\mathbf{b}} \mathrm{F}$-test for treatment differences was only significant at the $9 \%$ level, respectively. 
According to SRIVASTAVA and SINGH (1991), there is a positive relationship between total plant or root biomass and estimates of microbial $\mathrm{C}, \mathrm{N}$, and $\mathrm{P}$. Thus, lower initial $\mathrm{C}_{\text {mic }}$ content at $\mathrm{CH} 2$ indicated lower quantities of labile organic substrates.

At the severely degraded $\mathrm{CH} 2$ site, mineral and organic inputs significantly stimulated growth of microbial biomass due to improved maize growth within the first year. The $\mathrm{CH} 2$ soil was very poor in organic $\mathrm{C}$ and nutrients, significantly limiting microbial growth. Mineral fertilizer applications eliminated nutrient deficiencies and to some extent replenished $\mathrm{C}$ supply due to higher plant biomass production. A combined application of cotton seed waste with mineral fertilizer (All org) provides a balanced supply of nutrients and carbon which further increased levels of $\mathrm{C}_{\text {mic }}$ at the end of the season. The high values for $\mathrm{C}_{\mathrm{mic}}$ after the use of cotton seed waste alone (org) indicate that at this strongly degraded site soil microbial biomass was mainly controlled by organic substrates.

Significant differences in quantity and quality of maize straw residues (Table 46, Table 48) and of spontaneous fallow vegetation regrowth (Table 49, Table 50) due to different fertilizer treatments of the previous two seasons might have influenced the magnitude of $\mathrm{C}_{\text {mic }}$ at the beginning of the third cropping cycle at $\mathrm{CH} 2$ in June 1995. A positive effect of organic amendments on soil microbial biomass is often reported in the literature. For instance, LYNCH and PANTING (1980a,b) explained strong increases in $\mathrm{C}_{\text {mic }}$ as response to decomposing roots and incorporated crop residues providing substantial energy for the microbial biomass (PERROTT et al. 1990) which stimulates the soil microbial biomass growth (BUCHANAN and KING, 1992).

Throughout the experiment absolute values of $\mathrm{C}_{\text {mic }}$ remained much lower at the degraded $\mathrm{CH} 2$ site. Although, sufficient amounts of nutrients for maize production had been applied, $\mathrm{C}_{\text {mic }}$ at $\mathrm{CH} 2$ did not increase to the level reached at the non-degraded $\mathrm{CH} 1$ site. Moreover, a declining trend with time found in the (-P), (-Mo/-Zn) and control treatments indicates that maize cropping on a nutrient depleted savanna soil without external inputs, even at low yield levels, may lead to a degradation of the microbiological soil component. This might be caused by limited amounts of available $\mathrm{C}$ serving as a substrate and energy source but, also because of enhanced plant competition for nutrients such as $\mathrm{N}, \mathrm{P}, \mathrm{K}$ and $\mathrm{Zn}$ which might have been limiting microbial growth during the season. 
At the non-degraded $\mathrm{CH} 1$ site, fertilizer treatments did not result in significant changes in $\mathrm{C}_{\text {mic }}$ content. Here, available $\mathrm{C}$ serving as a substrate for microbial growth might have been more available which was indicated by the higher initial organic matter and microbial $\mathrm{C}$ content in the soil but also by higher seasonal variation. At the end of the third season in October 1995, the (-N) and the control treatments had nearly the same low microbial biomass levels suggesting that microbial growth was limited by $\mathrm{N}$ availability.

The values obtained for $\mathrm{C}_{\text {mic }}$ in this study were generally lower than those found in the literature for natural and agricultural soils, but similar to those in tropical soils of Nigeria, Brazil and Costa Rica. No comparable studies were found for similar agroecological conditions in West Africa. Relatively few attempts have been made to measure microbial biomass in dry tropical soils in India (SRIVASTAVA and SingH, 1988, 1991; SRIVASTAVA, 1992, GHOSHAL and SiNGH, 1995). Microbial C content ranged from $234-266 \mu \mathrm{g} \mathrm{g}^{-1}$ soil in a 15 and 40 years old cropped field to 361 - $435 \mu \mathrm{g} \mathrm{g}^{-1}$ soil in a grazed and fenced savanna and between 574 and $643 \mu \mathrm{g} \mathrm{g}^{-1}$ soil in forest soils (SRIVASTAVA, 1992). DIEKMANN (1997) presented values of $62-69 \mu \mathrm{g} \mathrm{g}^{-1}$ soil in the $0-20 \mathrm{~cm}$ layer in a traditional slash-and-burn system compared to $59 \mu \mathrm{g} \mathrm{g}^{-1}$ soil under a four year old fallow vegetation in eastern Amazonia of Brazil. MAZZARINo et al. (1993) reported similar values from 50 to $63 \mu \mathrm{g} \mathrm{g}^{-1}$ soil in four tropical agroecosystems in Costa Rica. Under continuous cropping in southern Nigeria (forest transition zone) $C_{\text {mic }}$ ranged from 39 to $86 \mu \mathrm{g} \mathrm{g}^{-1}$ soil (WICK, 1997) in the $0-10 \mathrm{~cm}$ layer. Microbial biomass was significantly higher at the least degraded site.

To sum up, in the studied savanna soils, soil microbial biomass appears to be more sensitive to changes in soil quality than total organic $\mathrm{C}$ and total $\mathrm{N}$. The incorporation of organic materials and better plant growth due to mineral fertilizer application raised the biomass $\mathrm{C}$ level significantly at the degraded $\mathrm{CH} 2$ site. This reflects increased numbers of microorganisms and supports the results of GoYAL et al. (1993) and PERUCCI (1992). If we accept that biomass $\mathrm{C}$ gives an idea of the potential microbial activity of a soil (NANNIPIERI et al., 1990), then the soils under study showed very low biological activity. 


\subsection{2 $\quad \mathrm{C}_{\text {mic }}-\mathrm{C}_{\text {org }}$-ratio}

In the literature the $\mathrm{C}_{\text {mic }}-\mathrm{C}_{\text {org }}$-ratio is used as an indicator for changes in microbial activity. Since $\mathrm{C}_{\text {mic }}$ represents the active part of SOM, the $\mathrm{C}_{\text {mic }}-\mathrm{C}_{\text {org }}$-ratio is also taken as an estimate of the quality of the SOM. The initial $\mathrm{C}_{\text {mic }}-\mathrm{C}_{\text {org }}$-ratio ranged from $0.7 \%$ at $\mathrm{CH} 1$ to $0.8 \%$ at $\mathrm{CH} 2$ and did not differ significantly between the two fields in June 1993 (Table 8).

The two-way ANOVA showed significant fertilizer effects on $\mathrm{C}_{\mathrm{mic}}-\mathrm{C}_{\mathrm{org}}$-ratio at $\mathrm{CH} 1$ $(p \leq 0.02)$ and $\mathrm{CH} 2(\mathrm{p} \leq 0.000)$, respectively (Table 22$)$. The ratio was also fluctuating strongly within the study period and differences among sampling dates were highly significant at both sites $(\mathrm{p} \leq 0.000)$. On average, $\mathrm{C}_{\text {mic }}-\mathrm{C}_{\text {org }}$-ratio increased from 0.7 to $1.3 \%$ at $\mathrm{CH} 1$ and from 0.8 to $0.9 \%$ at $\mathrm{CH} 2$ over the three cropping seasons. Variation within seasons followed the same trends as for soil microbial biomass since $\mathrm{C}_{\text {org }}$ content did not vary significantly among sampling dates and did not respond to fertilizer treatments.

In the first year, the addition of mineral fertilizer or a combined application with cotton seed waste increased $\mathrm{C}_{\text {mic }}-\mathrm{C}_{\text {org }}$-ratio in both soils, but to a greater extent at $\mathrm{CH} 2$. In contrast to the first season, in the second and third year fluctuations were much stronger at $\mathrm{CH} 1$ relative to $\mathrm{CH} 2$, indicating a much higher microbial activity in the $\mathrm{CH} 1$ soil. Changes in $\mathrm{C}_{\text {mic }}-\mathrm{C}_{\text {org }}$-ratio occurred in response to fertilizer inputs over three cropping cycles. During the second and third cropping period $\mathrm{C}_{\text {mic }}-\mathrm{C}_{\text {org }}$-ratio was consistently lowest in the (-N) and control treatments at both sites. At the degraded $\mathrm{CH} 2$ site after three seasons, the $\mathrm{C}_{\text {mic }}-\mathrm{C}_{\text {org }}$-ratio showed a reduction also in the subtractive $(-\mathrm{P}),(-\mathrm{K})$ and $(-\mathrm{S})$ treatments. A very strong decline was found in the $(-\mathrm{Mo} /-\mathrm{Zn})$ treatment as well as in the control.

Microbial biomass C constitutes 1 to $4 \%$ of the total soil C (JENKINSON and LADD, 1981). Due to differences in soils and crop management practices, as well as variations in sampling time and analytical methods, a wide range of $\mathrm{C}_{\text {mic }}-\mathrm{C}_{\text {org }}$-ratios from 0.3 to $>7 \%$ are reported in the literature (JENKINSON and LADD, 1981; ANDERSON and DOMSCH, 1989; OMAY et al., 1997, WICK et al., 1998). 
Table 22: Dynamics of the $\mathrm{C}_{\text {mic }}-\mathrm{C}_{\text {org }}$-ratio (\%) in the $0-30 \mathrm{~cm}$ soil layer from June 1993 until October 1995 in the minus-one trials. Locations: CH 1, CH 2.

\begin{tabular}{|c|c|c|c|c|c|c|}
\hline \multirow[b]{2}{*}{ Treatment } & \multicolumn{6}{|c|}{ Sampling date } \\
\hline & $06 / 93$ & $10 / 93$ & $06 / 94$ & $10 / 94$ & $06 / 95$ & $10 / 95$ \\
\hline \multicolumn{7}{|c|}{ CH 1 (non-degraded) } \\
\hline All & 0.5 & 1.5 & 1.7 & 1.8 & 1.0 & 1.6 \\
\hline All org & 0.6 & 1.3 & 1.6 & 1.5 & 0.8 & 1.5 \\
\hline$-\mathbf{N}$ & 0.8 & 1.5 & 1.1 & 1.4 & 0.7 & 1.0 \\
\hline$-\mathbf{P}$ & 0.5 & 1.4 & 1.0 & 1.1 & 0.8 & 1.1 \\
\hline$-K$ & 0.5 & 1.4 & 1.1 & 1.3 & 0.9 & 1.3 \\
\hline -Ca/org & 0.6 & 1.4 & 1.0 & 1.6 & 0.8 & 1.5 \\
\hline -Mg & 0.8 & 1.6 & 1.2 & 1.5 & 0.8 & 1.4 \\
\hline$-S$ & 1.4 & 1.5 & 1.2 & 1.5 & 0.8 & 1.3 \\
\hline$-M o /-Z n$ & 0.5 & 1.6 & 1.1 & 1.6 & 0.9 & 1.4 \\
\hline none & 0.6 & 1.4 & 1.1 & 1.5 & 0.6 & 1.0 \\
\hline LSD $(0.05)$ & ns & ns & 0.4 & ns & ns & $0.5^{b}$ \\
\hline Mean & 0.7 & 1.5 & 1.2 & 1.5 & 0.8 & 1.3 \\
\hline${ }^{\mathrm{a}} \mathbf{L S D}(\mathbf{0 . 0 5})$ & 0.2 & & & & & \\
\hline \multicolumn{7}{|c|}{$\mathrm{CH} 2$ (degraded) } \\
\hline All & 0.5 & 1.7 & 0.8 & 1.1 & 1.0 & 1.1 \\
\hline All org & 0.8 & 2.2 & 0.9 & 1.4 & 1.2 & 1.5 \\
\hline$-\mathbf{N}$ & 0.5 & 1.2 & 0.5 & 0.6 & 0.7 & 0.7 \\
\hline$-P$ & 0.7 & 0.8 & 0.4 & 0.9 & 0.7 & 0.7 \\
\hline$-\mathbf{K}$ & 0.8 & 0.9 & 0.7 & 1.1 & 0.8 & 0.8 \\
\hline -Ca/org & 0.8 & 1.1 & 0.9 & 1.5 & 1.3 & 1.2 \\
\hline -Mg & 0.4 & 1.4 & 0.7 & 0.9 & 0.9 & 0.6 \\
\hline$-S$ & 0.9 & 1.7 & 0.9 & 1.2 & 1.1 & 0.9 \\
\hline -Mo/-Zn & 1.1 & 1.2 & 0.6 & 1.2 & 0.7 & 0.9 \\
\hline none & 1.1 & 0.7 & 0.6 & 0.6 & 0.7 & 0.6 \\
\hline LSD (0.05) & ns & 0.8 & 0.4 & ns & 0.4 & 0.5 \\
\hline Mean & 0.8 & 1.3 & 0.7 & 1.1 & 0.9 & 0.9 \\
\hline${ }^{\mathrm{a}} \mathbf{L S D}(\mathbf{0 . 0 5})$ & 0.2 & & & & & \\
\hline
\end{tabular}

${ }^{a}$ LSD-test for significant differences of the sampling dates after 2-way ANOVA across pooled treatments.

${ }^{\mathbf{b}} \mathrm{F}$-test for treatment differences was only significant at the $10 \%$ level. 


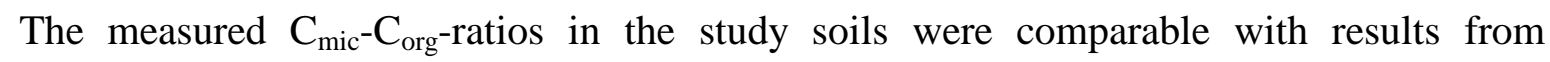
other tropical agroecosystems. In the present study, the values ranged from 0.7 to 1.3 . GHOSHAL and SING (1995) presented much higher $\mathrm{C}_{\text {mic }}-\mathrm{C}_{\text {org }}$-ratios; ranging from $2.8 \%$ in the control to $3.3 \%$ in manure plus fertilizer plots in a dryland agroecosystem in India. In contrast, OMAY et al. (1997) reported similar but slightly lower $\mathrm{C}_{\text {mic }}-\mathrm{C}_{\text {org }}$-ratios from 0.3 to $0.9 \%$ in experimental soils in Kansas, USA. DIEKMANN (1997) found $\mathrm{C}_{\text {mic }}-\mathrm{C}_{\text {org }}$-ratios between $1.0-1.1 \%$ in slash and burn cropping systems in the $5-20 \mathrm{~cm}$ layer compared to $0.9 \%$ under a four year old fallow vegetation in eastern Amazonia (Brazil). MAZZARINo et al. (1993) reported very low values for the $\mathrm{C}_{\mathrm{mic}}-\mathrm{C}_{\mathrm{org}}$-ratio from 0.12 to $0.14 \%$ in four tropical agroecosystems in Costa Rica, indicating that in these soils SOM is relatively resistant to decomposition. $\mathrm{C}_{\mathrm{mic}}-\mathrm{C}_{\mathrm{org}}$-ratios in soils under continuous cropping in the forest transition zone in southern Nigeria ranged from $0.4 \%$ to $1.2 \%$ in the $5-10 \mathrm{~cm}$ layer (WICK, 1997).

In the soils studied, we have observed that mineral and organic inputs increased the proportion of organic $\mathrm{C}$ present as microbial biomass C. However, on the basis of short-term estimates, an increase in this ratio cannot be considered to indicate an accumulation in SOM because such increases are often transient (ANDERSON and DoMsch, 1989). The results suggest that this ratio is a reflection of the potential of SOM mineralization rather than of the stability of the SOM. The lower the ratio, the lower the tendency of the organic matter to mineralize. When amended with fresh cotton seed wastes but also after high fertilizer inputs the soils showed a higher $\mathrm{C}_{\text {mic }}-\mathrm{C}_{\text {org }}$-ratio.

Nutrient limitations by $\mathrm{N}$ and $\mathrm{P}$ at both sites, and by $\mathrm{Zn}$ and $\mathrm{Mg}$, in particular at $\mathrm{CH} 2$, control overall microbial growth and activity and consequently SOM mineralization. This would indicate that the $\mathrm{C}_{\text {mic }}-\mathrm{C}_{\text {org }}$-ratio is potentially a sensitive index of input management effects on SOM and of changes in SOM, which can be used effectively to follow the state of a soil's organic matter content after addition of organic materials. 


\subsubsection{Acid phosphatase activity}

Initial acid phosphatase activities $\left(\mu \mathrm{g}\right.$ p-nitrophenol $\left.\mathrm{g}^{-1} \mathrm{~h}^{-1}\right)$ in June 1993 were significantly lower at $\mathrm{CH} 2(36 \%)$ than in the fertile $\mathrm{CH} 1$ top soil (Table 8). The two-way ANOVA identified both, sampling date and treatment as highly significant $(p \leq 0.001)$ at both sites. Throughout the experimental period acid phosphatase activities fluctuated much stronger at $\mathrm{CH} 1$ than at the degraded $\mathrm{CH} 2$ site. There was no significant interaction between treatment and sampling time (Table 23).

Significant treatment differences existed at the end of the first (October 1993) and second (October 1994) cropping cycle at $\mathrm{CH}$ 1. In October 1993, the highest acid phosphatase activities were found after combined mineral and organic fertilization (All org) and in the (-P) treatment. The $(-\mathrm{N})$ and $(-\mathrm{Mo} /-\mathrm{Zn})$ treatments and the control had significantly lower acid phosphatase activities than treatments (All org) and (-P). At the end of the second cropping season there was a similar pattern with the highest acid phosphatase activities in the treatments (-P), (All org) and (org). Acid phosphatase activity was lowest in the treatments $(-\mathrm{S}),(-\mathrm{N})$, and $(-\mathrm{Mo} / \mathrm{Zn})$ and the control. Results from the third season followed the same pattern, however differences between treatments were not significant at the $5 \%$ level.

At the degraded $\mathrm{CH} 2$ site, significant treatment effects were recorded at the end of the second and third season (October 1994), however, only at the 7 \% level. In October 1994 acid phosphatase activities were highest in the (-P) and lowest in the (-N) and (-Mo/- $\mathrm{Zn})$ treatments as well as in the control. The same trends were found in October 1995. Acid phosphatase activity was highest in the (-P) treatment followed by the treatment (All org) and the completely fertilized plots (All). Soil acid phosphatase activity again revealed to be lowest in the subtractive $(-\mathrm{N}),(-\mathrm{Mo} /-\mathrm{Zn})$ treatments and in the control.

After three years of maize soil acid phosphatase activity was highest in the (-P) treatment at both sites. HÄUSSLING and MARSCHNER (1989) and TADANO et al. (1993) also showed that without $\mathrm{P}$ fertilization plant roots had higher phosphatase activity on their surfaces in order to compensate for lower soil available $\mathrm{P}$ by higher hydrolysis of organic $\mathrm{P}$ esters.

Cotton seed waste itself might have been a source of the enzyme. Organic amendments provide easily available $\mathrm{C}$, thereby stimulating microbial growth and thus, acid phosphatase activity. 
Table 23: Dynamics of soil acid phosphatase activity ( $\mu \mathrm{g}$-nitrophenol $\mathrm{g}^{-1} \mathrm{hr}^{-1}$ ) in the 0 - $30 \mathrm{~cm}$ soil layer from June 1993 until October 1995 in the minus-one trials. Locations: $\mathrm{CH} 1, \mathrm{CH} 2$.

\begin{tabular}{|c|c|c|c|c|c|c|}
\hline \multirow[b]{2}{*}{ Treatment } & \multicolumn{6}{|c|}{ Sampling date } \\
\hline & $06 / 93$ & $10 / 93$ & $06 / 94$ & $10 / 94$ & $06 / 95$ & $10 / 95$ \\
\hline \multicolumn{7}{|c|}{ CH 1 (non-degraded) } \\
\hline All & 197 & 137 & 223 & 223 & 196 & 196 \\
\hline All org & 225 & 167 & 237 & 238 & 186 & 215 \\
\hline$-\mathbf{N}$ & 214 & 144 & 207 & 200 & 179 & 189 \\
\hline$-\mathbf{P}$ & 225 & 166 & 247 & 273 & 197 & 225 \\
\hline$-\mathbf{K}$ & 229 & 165 & 227 & 232 & 172 & 201 \\
\hline -Ca/org & 217 & 154 & 222 & 237 & 177 & 202 \\
\hline$-M g$ & 210 & 155 & 219 & 235 & 187 & 212 \\
\hline$-S$ & 219 & 147 & 212 & 206 & 204 & 206 \\
\hline -Mo/-Zn & 190 & 134 & 194 & 208 & 153 & 190 \\
\hline none & 221 & 138 & 204 & 208 & 147 & 180 \\
\hline LSD (0.05) & ns & 23 & ns & 40 & ns & ns \\
\hline Mean & 215 & 151 & 219 & 226 & 180 & 202 \\
\hline${ }^{\mathrm{a}} \mathrm{LSD}(\mathbf{0 . 0 5})$ & 13 & & & & & \\
\hline \multicolumn{7}{|c|}{$\mathrm{CH} 2$ (degraded) } \\
\hline All & 156 & 155 & 149 & 129 & 100 & 121 \\
\hline All org & 134 & 133 & 139 & 119 & 103 & 124 \\
\hline$-\mathbf{N}$ & 117 & 116 & 116 & 96 & 74 & 104 \\
\hline$-P$ & 127 & 152 & 158 & 139 & 100 & 140 \\
\hline$-K$ & 139 & 133 & 136 & 112 & 97 & 119 \\
\hline -Ca/org & 143 & 125 & 130 & 109 & 88 & 113 \\
\hline -Mg & 129 & 133 & 139 & 124 & 98 & 110 \\
\hline$-S$ & 141 & 138 & 134 & 109 & 84 & 113 \\
\hline -Mo/-Zn & 140 & 138 & 145 & 110 & 102 & 98 \\
\hline none & 143 & 115 & 117 & 104 & 72 & 102 \\
\hline LSD (0.05) & ns & ns & ns & $26^{b}$ & $24^{\mathrm{b}}$ & $25^{b}$ \\
\hline Mean & 137 & 134 & 136 & 115 & 92 & 114 \\
\hline${ }^{\mathrm{a}} \mathrm{LSD}(\mathbf{0 . 0 5})$ & 11 & & & & & \\
\hline
\end{tabular}

${ }^{a}$ LSD-test for significant differences of the sampling dates after 2-way ANOVA across pooled treatments. ${ }^{\mathbf{b}}$ F-test for treatment differences was only significant at the $10 \%$ level. 
Acid phosphatase activity at $\mathrm{CH} 2$ remained substantially lower than at $\mathrm{CH} 1$, even after adequate mineral and organic fertilizer application. Acid phosphatase activity was apparently not only controlled by mineral and organic nutrient inputs, but also by other factors such as availability of carbohydrates or proteins as energy sources, which influence plant and microbial growth but also microbial nutrient turnover. For instance, the enzyme activity might be reduced due to lacking of suitable organic substrate such as easily accessible P-esters at the degraded $\mathrm{CH} 2$ site. It could also have been the case that the enzyme was stabilized in enzyme-humus-complexes. Since acid phosphatase is partly produced by soil microrganisms and therefore may be an appropriate indicator of relative microbial activity (JORDAN et al., 1995), these observations might be an indication for degradation of the microbial soil component at this severely degraded location.

Soil acid phosphatase activity measured in the study soils was similar to that observed in a variety of other soils (SPEIR and ROSS, 1978; ADAMS, 1992, JORDAN et al., 1995; WICK, 1997). In contrast, DIEKMANN (1997) reported acid phosphatase activities up to ten times higher in cropped and fallow fields in the eastern Amazonia region of Brazil.

Low available soil $\mathrm{P}$ content in the (-P) plots seems to promote higher acid phosphatase activitiy if all other nutrients have been applied sufficiently. However, there was no correlation between acid phosphatase activity and soil inorganic $\mathrm{P}$ content. In the $\mathrm{P}$ fertilized (-N) treatment but also in the control plots with low available soil $\mathrm{P}$, acid phosphatase activity remained lowest. In these plots maize growth was very poor and SMB was lowest.

Relationship of acid phosphatase activity with the soil organic $\mathrm{P}$ fraction confirmed the importance of this enzyme in soil organic $\mathrm{P}$ turnover. This suggests that organic $\mathrm{P}$ may have been a better indicator of plant available P. Phosphatases are adaptive enzymes and thus their activity in roots increase, when plants grow under $\mathrm{P}$ deficient conditions (VUORINEN and SAHARINEN, 1996). FOX and COMERFORD (1992) found similar results as presented above, reporting that acid phosphatase activity was lower in soils where P fertilizer had been added. In contrast, WICK (1997) did not detect relationships between the inorganic and organic phosphorus status and acid phosphatase activity in experimental soils at IITA, Nigeria. This observation is supported by ADAMS (1992) for eucalyptus forest soils in Australia reporting that acid phosphatase activity could not be significantly related to any single organic or inorganic $\mathrm{P}$ fraction. 


\subsubsection{Alkaline phosphatase activity}

Initial alkaline phosphatase activity was considerably lower at the degraded $\mathrm{CH} 2$ site (59 \%) than at the non-degraded $\mathrm{CH} 1$ site (Table 8). Sampling date had a significant influence on the level of alkaline phosphatase activity at $\mathrm{CH} 1(p \leq 0.04)$ and CH 2 ( $p \leq 0.000)$. No significant treatment effect and interaction between treatment and sampling date was detected at both sites (Table 24).

Acid phosphatase activities were much higher than alkaline phosphatase activities. This is consistent with the optimal $\mathrm{pH}$ for acid phosphatase of 6.0 - 6.6 (NAKAS et al., 1987). Throughout the experimental years, alkaline phosphatase activity was much lower at the degraded $\mathrm{CH} 2$ site than at the more fertile $\mathrm{CH} 1$ site. This is in line with results from WICK (1997) at IITA in Nigeria, who reported significantly lower alkaline phosphatase activity in highly degraded soils. The levels of alkaline phosphatase activity in the studied savanna soils was much lower than those found in southern Nigeria (WICK, 1997) and approximately ten times lower than values obtained in California, USA (MARTENS et al., 1992). The levels of the activities measured in savanna soils were comparable to those obtained in the eastern Amazon in Brazil (DIEKMANN, 1997), in Umbria in Italy (PERUCCI, 1992) and in Missouri, USA (JORDAN et al., 1995).

Organic amendments did not affect alkaline phosphatase activities during the three-year study. In contrast, MARTENS et al. (1992) reported that soil alkaline phosphatase activity fluctuated dramatically with time due to stimulation by organic amendments in soils in California, USA.

Temporal variations were less as compared to variations of microbial biomass and of acid phosphatase activities. No decline in activity was found during the dry season. The stabilization of the enzyme by humic substances was responsible for lower variation in alkaline phosphatase activities in soils in the forest transition zone in Nigeria (WICK, 1997). She concluded that the activity of soil enzymes may remain rather stable despite the influence of environmental changes as compared to microbial biomass. Since alkaline phosphatases are free enzymes and produced solely by soil microorganisms (CHHONDAR and TARAFDAR, 1984; NAKAS et al., 1987; TADANO et al., 1993) the differences in activity between the sites might be related to contrasting quantity, quality and activity of the microbial biomass and to contrasting nutrient availability at the differentially degraded sites. 
Table 24: Dynamics of soil alkaline phosphatase activity $\left(\mu \mathrm{g} \mathrm{p}\right.$-nitrophenol $\left.\mathrm{g}^{-1} \mathrm{hr}^{-1}\right)$ in the $0-30 \mathrm{~cm}$ soil layer from June 1993 to October 1995 in the minus-one trials.

Locations: $\mathrm{CH} 1, \mathrm{CH} 2$.

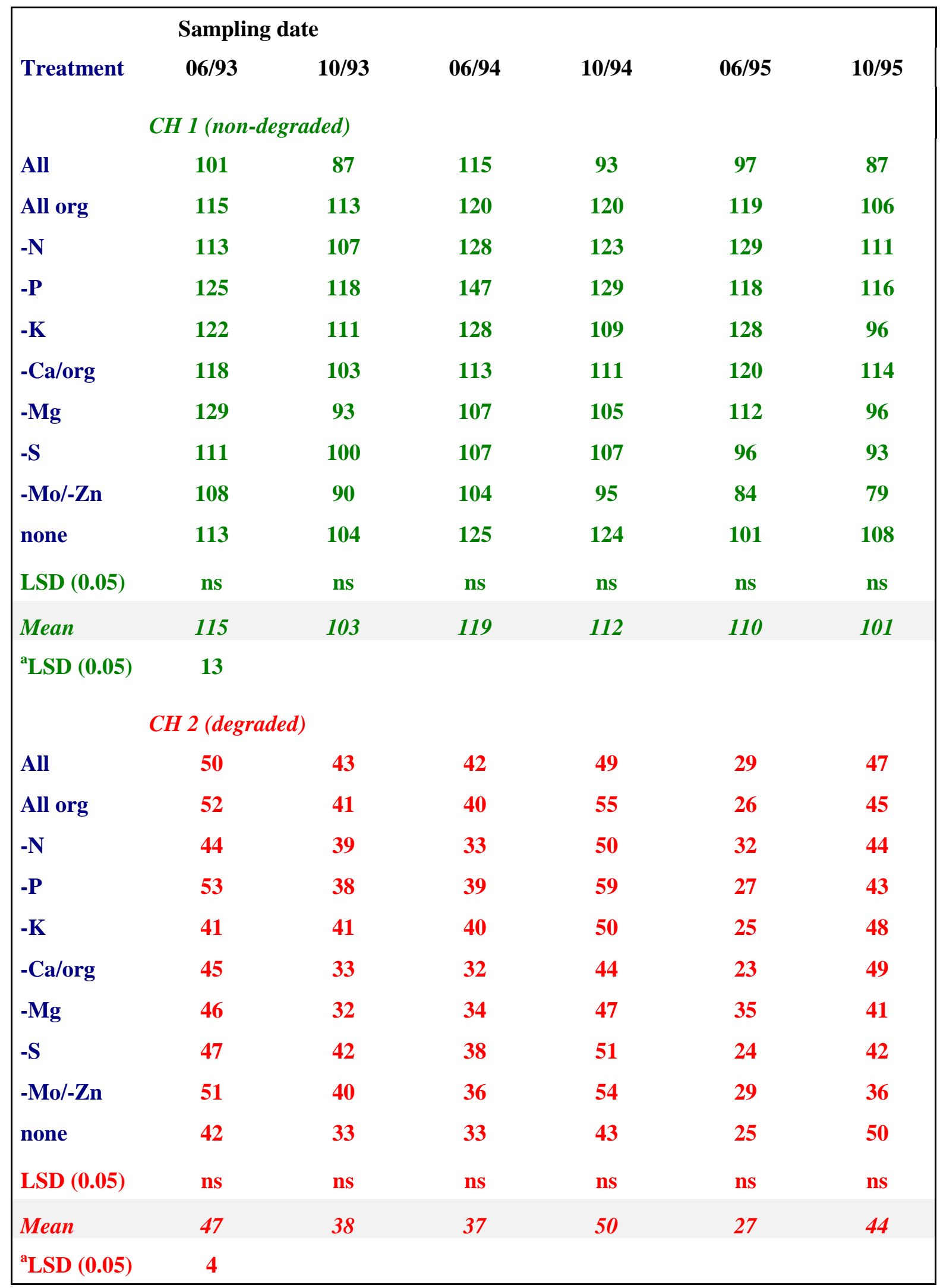

${ }^{a}$ LSD-test for significant differences of the sampling dates after 2-way ANOVA across pooled treatments. 


\subsubsection{B-Glucosidase activity}

Initial B-glucosidase activity was much lower at the degraded $\mathrm{CH} 2$ field (-61\%) as compared to the non-degraded $\mathrm{CH} 1$ field (Table 8). Throughout the experimental years, levels of $\mathrm{B}$-glucosidase activity remained much lower in the $\mathrm{CH} 2$ field (Table 25). At both study sites, there was a trend for increasing B-glucosidase activity with time. At the non-degraded CH 1 site, B-glucosidase activity varied significantly over time. At the degraded CH 2 site, treatments had a strong effect on B-glucosidase activity $(\mathrm{p} \leq 0.000)$ but changes over time were also significant $(\mathrm{p} \leq 0.000)$. At both sites, there was no significant interaction between treatment and sampling date. Seasonal variation was somewhat higher at $\mathrm{CH} 1$ than at $\mathrm{CH}$ 2. B-Glucosidase activity was always smaller at the beginning of the cropping season and higher at the end of the cropping cycle, especially in the fertilized plots at both sites.

At no sampling date we find significant differences between treatments at the non-degraded $\mathrm{CH} 1$ site. In contrast, at the degraded $\mathrm{CH} 2$ site significant treatment effects were recorded at the end of the second (October 1994), at the beginning (June 1995) and at the end of the third season (October 1995). In October 1994 B-glucosidase activity was lowest in the $(-\mathrm{N})$ and (-P) treatments and in the control. The same trends for (-N) and (-P) were observed in June and October 1995. The highest B-glucosidase activities were measured in the complete (All) and after combined fertilization (All org), whereas the lowest activity was found in the control at the end of the third cropping cycle. These observations suggest that microorganisms had to compete with maize for these nutrients in the soil. The enzyme activity in the degraded $\mathrm{CH} 2$ soil was probably influenced directly by the availability of $\mathrm{N}$ and $\mathrm{P}$, and/or indirectly by the availability of cellulitic organic substrates. This could have led to either limited microbial growth because of $\mathrm{N}$ and $\mathrm{P}$ deficiency in the soil, but also to significantly lower maize yields. Subsequently lower amounts of maize crop residues and nutrient were recycled in these plots.

The use of inorganic and organic fertilizer most likely increased plant and root biomass production which in turn increased the amount of residues returned to the soil each year. Thus, management practices that increased the amount of organic residues left in the soil increased microbial biomass and microbial activity as indicated by higher acid phosphatase activity as well as by higher B-glucosidase activity. This is supported by KIRCHNER et al. (1993) who reported higher acid phosphatase and B-glucosidase activities after $\mathrm{N}$ fertilization as compared to unfertilized soil in North Carolina, USA. 
Table 25: Dynamics of soil B-glucosidase activity ( $\mu \mathrm{g} \mathrm{p}$-nitrophenol $\left.\mathrm{g}^{-1} \mathrm{hr}^{-1}\right)$ in the $0-30$ cm soil layer from June 1993 to October 1995. Locations: CH 1, CH 2.

\begin{tabular}{|c|c|c|c|c|c|c|}
\hline \multirow[b]{2}{*}{ Treatment } & \multicolumn{6}{|c|}{ Sampling date } \\
\hline & $06 / 93$ & $10 / 93$ & $06 / 94$ & $10 / 94$ & $06 / 95$ & $10 / 95$ \\
\hline \multicolumn{7}{|c|}{ CH 1 (non-degraded) } \\
\hline All & 25 & 34 & 41 & 43 & 28 & 34 \\
\hline All org & 28 & 40 & 37 & 47 & 35 & 40 \\
\hline$-\mathbf{N}$ & 30 & 34 & 35 & 44 & 31 & 37 \\
\hline$-\mathbf{P}$ & 28 & 43 & 39 & 46 & 32 & 39 \\
\hline$-K$ & 31 & 37 & 37 & 40 & 26 & 35 \\
\hline -Ca/org & 31 & 39 & 32 & 51 & 36 & 39 \\
\hline$-\mathbf{M g}$ & 28 & 41 & 37 & 44 & 23 & 35 \\
\hline$-S$ & 29 & 31 & 32 & 37 & 25 & 36 \\
\hline -Mo/-Zn & 25 & 36 & 30 & 40 & 25 & 27 \\
\hline none & 28 & 41 & 33 & 42 & 22 & 32 \\
\hline LSD (0.05) & ns & ns & ns & ns & ns & ns \\
\hline Mean & 28 & 37 & 35 & 44 & 28 & 35 \\
\hline${ }^{\mathrm{a}} \mathbf{L S D}(\mathbf{0 . 0 5})$ & 4 & & & & & \\
\hline \multicolumn{7}{|c|}{ CH 2 (degraded) } \\
\hline All & 11 & 18 & 15 & 20 & 13 & 25 \\
\hline All org & 11 & 18 & 16 & 22 & 12 & 25 \\
\hline$-\mathbf{N}$ & 11 & 13 & 15 & 14 & 11 & 15 \\
\hline$-\mathbf{P}$ & 9 & 15 & 11 & 15 & 10 & 20 \\
\hline$-\mathbf{K}$ & 9 & 16 & 14 & 18 & 13 & 24 \\
\hline -Ca/org & 11 & 13 & 13 & 17 & 9 & 21 \\
\hline -Mg & 11 & 17 & 17 & 16 & 11 & 22 \\
\hline$-S$ & 12 & 17 & 17 & 17 & 8 & 19 \\
\hline -Mo/-Zn & 11 & 17 & 16 & 19 & 12 & 19 \\
\hline none & 10 & 15 & 11 & 14 & 9 & 14 \\
\hline LSD (0.05) & ns & ns & ns & 5 & $4^{b}$ & 6 \\
\hline Mean & 11 & 16 & 14 & 17 & 11 & 20 \\
\hline${ }^{\mathrm{a}} \mathbf{L S D}(\mathbf{0 . 0 5})$ & 2 & & & & & \\
\hline
\end{tabular}

${ }^{a}$ LSD-test for significant differences of the sampling dates after 2-way ANOVA across pooled treatments.

${ }^{\mathbf{b}}$ F-test for significant differences of the treatments was only significant at the $9 \%$ level. 
KIRCHNER et al. (1993) concluded that fertilization affects the SMB by increasing root biomass, root exudates, and crop residues, thus providing increased substrate for microbial growth. MARTENS et al. (1992) reported that B-glucosidase activity was significantly increased by the addition of plant materials due to the addition of enzymes present in plant residues in addition to stimulating microbial production.

The range of the values obtained for $\beta$-glucosidase activity are in agreement with those obtained in the eastern Amazon region in Brazil (DIEKMANN, 1997), in the forest transition zone in Nigeria (WICK, 1997), and in North Carolina, USA (KIRCHNER et al., 1993). In contrast, DENG and TABATABAI (1996) and FRIEDEL et al. (1996) found much higher ß-glucosidase activities in soils in Iowa, USA and Germany, respectively.

Lower ß-glucosidase activities were recorded at the degraded site. This is in agreement with GARCIA et al. (1994) and GARCIA and HERnANDEZ (1997) who reported that B-glucosidase activities were lower at the most degraded soils in south-eastern Spain. This was attributed to both, reduced SOM mineralization and reduced activity of the carbon cycle. Observations from IITA in Nigeria also show significantly lower ß-glucosidase activity in the most degraded soils. Continuous cultivation resulted not only in a marked decline of soil organic $\mathrm{C}$ but also in a severe decline in soil B-glucosidase activity (DIEKMANN, 1997; WICK, 1997).

The results support findings presented by GANDER et al. (1994) and GARCIA et al. (1994), who considered B-glucosidase activity as an index for biomass turnover. Furthermore, DENG and TABATABAI (1996) concluded that B-glucosidase activity is the driving force in the decomposition of carbohydrates in soils and the activity of the enzyme is primarily dependent upon available cellulose as substrate, which was confirmed by the results presented above. GARCIA and HERNANDEZ (1997) suggested that B-glucosidase activity is closely related to changes undergone by SOM during soil degradation. However, WICK et al. (1998) stated that B-glucosidase was more sensitive in indicating changes in soil quality as compared to total organic carbon. 


\subsubsection{Protease activity}

Initial protease activity was significantly lower in the degraded $\mathrm{CH} 2$ soil (48\%) as compared to the non-degraded $\mathrm{CH} 1$ soil (Table 8). The two-way ANOVA computed for $\mathrm{CH} 1$ revealed that only sampling date $(p \leq 0.000)$ significantly affected soil protease activity (Table 26). At CH 2 both, treatment $(p \leq 0.000)$ and sampling time $(p \leq 0.000)$ had a significant influence on protease activity. At both sites there was no significant interaction between treatment and sampling date.

Protease activity fluctuated highly during the cropping season in all treatments of the non-degraded $\mathrm{CH} 1$ soil, whereas in the degraded $\mathrm{CH} 2$ soil, fluctuations were very low. At $\mathrm{CH} 1$ a pronounced increase was observed from June to October followed by a strong decline from October to June. At the $\mathrm{CH} 2$ site, protease activity was significantly lower throughout the three cropping seasons as compared to the non-degraded $\mathrm{CH} 1$ site, even, after high mineral and/or organic fertilizer input.

No treatment effects were found at $\mathrm{CH} 1$ (Table 26). In contrast, at the degraded CH 2 site, adequate mineral fertilizer application to maize increased protease activity at the end of the second and third cropping cycle. Without mineral $\mathrm{P}$ application, protease activity was lowest. Also in the control and (-N) treatment protease activity tended to be lower.

The reduced protease activity at the beginning of the season might be due to the long dry season of about six month. WICK (1997) observed a pronounced decline in protease activity during the dry season in soils at IITA in southern Nigeria. Similar results were obtained by LOLL and BOLLAG (1983) and WATANABE and HAYANO (1996) as cited by WICK (1997) confirming that low soil moisture contents restrict proteolysis.

The soil protease activity measured in the savanna soils was similar to the values presented by Wick (1997) who found protease activities from $21 \mu \mathrm{g}$ to $152 \mu \mathrm{g} \mathrm{g}^{-1} 2 \mathrm{~h}^{-1}$ in the $0-10 \mathrm{~cm}$ layer for experimental soils at IITA, Nigeria. However, WICK (1997) did not observe a consistent trend in protease activity as related to site degradation in these experimental soils in Nigeria. 
Table 26: Dynamics of soil protease activity ( $\mu \mathrm{g}$ tyrosin $\mathrm{g}^{-1} 2 \mathrm{hr}^{-1}$ ) in the $0-30 \mathrm{~cm}$ layer from June 1993 to October 1995. Locations: CH 1, CH 2.

\begin{tabular}{|c|c|c|c|c|c|c|}
\hline \multirow[b]{2}{*}{ Treatment } & \multicolumn{6}{|c|}{ Sampling date } \\
\hline & $06 / 93$ & $10 / 93$ & $06 / 94$ & $10 / 94$ & $06 / 95$ & $10 / 95$ \\
\hline \multicolumn{7}{|c|}{ CH 1 (non-degraded) } \\
\hline All & 57 & 68 & 44 & 114 & 37 & 57 \\
\hline All org & 64 & 77 & 42 & 110 & 41 & 76 \\
\hline$-\mathbf{N}$ & 69 & 79 & 41 & 101 & 38 & 69 \\
\hline$-\mathbf{P}$ & 69 & 84 & 47 & 126 & 34 & 70 \\
\hline$-K$ & 70 & 84 & 47 & 114 & 42 & 65 \\
\hline -Ca/org & 66 & 73 & 40 & 118 & 42 & 68 \\
\hline -Mg & 67 & 88 & 41 & 111 & 39 & 81 \\
\hline$-S$ & 58 & 85 & 42 & 112 & 36 & 64 \\
\hline$-M o /-Z n$ & 65 & 84 & 36 & 120 & 35 & 58 \\
\hline none & 66 & 82 & 44 & 118 & 32 & 66 \\
\hline LSD (0.05) & ns & ns & ns & ns & ns & ns \\
\hline Mean & 65 & 80 & 42 & 114 & 38 & 67 \\
\hline${ }^{\mathrm{a}} \mathbf{L S D}(\mathbf{0 . 0 5})$ & 8 & & & & & \\
\hline \multicolumn{7}{|c|}{ CH 2 (degraded) } \\
\hline All & 37 & 39 & 37 & 53 & 29 & 34 \\
\hline All org & 31 & 35 & 37 & 43 & 26 & 35 \\
\hline$-\mathbf{N}$ & 33 & 24 & 32 & 38 & 21 & 25 \\
\hline$-\mathbf{P}$ & 34 & 24 & 29 & 34 & 24 & 19 \\
\hline -K & 33 & 28 & 28 & 40 & 30 & 34 \\
\hline -Ca/org & 35 & 30 & 31 & 35 & 30 & 31 \\
\hline -Mg & 35 & 29 & 33 & 39 & 25 & 32 \\
\hline$-S$ & 36 & 27 & 35 & 36 & 18 & 38 \\
\hline -Mo/-Zn & 35 & 28 & 36 & 36 & 24 & 27 \\
\hline none & 28 & 19 & 27 & 34 & 19 & 23 \\
\hline LSD (0.05) & ns & ns & ns & $12^{\mathrm{b}}$ & ns & 12 \\
\hline Mean & 34 & 28 & 33 & 39 & 25 & 30 \\
\hline${ }^{\mathrm{a}} \mathbf{L S D}(\mathbf{0 . 0 5})$ & 4 & & & & & \\
\hline
\end{tabular}

${ }^{a}$ LSD-test for significant differences of the sampling dates after 2-way ANOVA across pooled treatments. ${ }^{\mathbf{b}}$ F-test for treatment differences was only significant at the $10 \%$ level. 


\subsubsection{Correlations between microbial parameters and soil and plant parameters}

Soil microbial biomass was not correlated to maize yields and nutrient uptake. The relationship between soil microbial biomass and chemical soil parameters and enzyme activities were highly significant (Annex, Table 54). With regard to soil chemical parameters, the highest correlation coefficient was recorded between $\mathrm{C}_{\text {mic }}$ and $\mathrm{C}_{\text {org }}$ $\left(\mathrm{r}=0.58^{* * *}\right)$. Moderate correlations were obtained between $\mathrm{C}_{\mathrm{mic}}$ and total $\mathrm{N}\left(\mathrm{r}=0.55^{* * *}\right)$, organic $\mathrm{P}\left(\mathrm{r}=0.55^{* * *}\right)$ and $\mathrm{CEC}\left(\mathrm{r}=0.54^{* * *}\right)$. By regarding the biochemical soil properties, the highest correlation coefficient occurred for $\mathrm{C}_{\text {mic }}$ with $\beta$-glucosidase activity $\left(\mathrm{r}=0.69^{* * *}\right)$. The relationships with protease activity $(\mathrm{r}=0.57 * * *)$, alkaline phosphatase activity $\left(\mathrm{r}=0.55^{* * *}\right)$ and acid phosphatase activity $(\mathrm{r}=0.54 * * *)$ were relatively strong as well. The results revealed that in the study soils SMB is closely related to organically bound nutrients such as N, P, and CEC and their release, as it is clearly indicated by relatively strong correlations with soil enzyme activities of the $\mathrm{C}-, \mathrm{N}-$, and P-cycle.

Microbial biomass is the driving force in decomposition processes and biochemical nutrient cycling in soil (TESSIER et al., 1998). It is therefore a crucial factor in soil fertility and ecosystem functioning in savanna soils. In these processes soil enzymes play an active role. For instance, B-glucosidase is involved in degradation of cellulosic materials. The hydrolysis products are believed to be important energy sources (TABATABAI, 1994). Protease is hydrolyzing proteins and oligopeptides and phosphatases act on organic phosphorus compounds. However, it is not clear from the data what strategy the soil microbial population adopts in the acquisition of energy, $\mathrm{C}$ and $\mathrm{N}$. Is the carbohydrate used for primarily energy supply and the protein for $\mathrm{N}$ or is the protein used for both energy and N? Since the correlation with B-glucosidase activity was stronger than with protease activity it might be concluded that carbohydrate degradation is the major process for the acquisition of energy.

As found for SMB, no significant correlations were found between acid phosphatase activity and maize yield parameters or P uptake at harvest in October 1995. In order to investigate relationships between acid phosphatase activity and soil properties, correlation coefficients were calculated based on data pooled across sampling dates, fields and treatments for all measured soil parameters. There was no correlation between acid phosphatase activity and inorganic (available) Bray-I phosphorus content in the soil. In contrast, acid phosphatase activity was highly significantly correlated with soil $\mathrm{pH}$ 
$(\mathrm{r}=0.59)$, organic $\mathrm{C}(\mathrm{r}=0.69)$, total $\mathrm{N}(\mathrm{r}=0.67)$, CEC $(\mathrm{r}=0.67), \mathrm{Ca}(\mathrm{r}=0.68)$, $\mathrm{Mg}(\mathrm{r}=0.63)$, organic $\mathrm{P}(\mathrm{r}=0.68)$, microbial $\mathrm{C}(\mathrm{r}=0.54)$, alkaline phosphatase activity $(\mathrm{r}=0.73), \beta$-glucosidase activity $(\mathrm{r}=0.72)$ and protease activity $(\mathrm{r}=0.57)$. WICK $(1997)$ did not find significant correlations with soil carbon content, total N, and SMB in soils at IITA, in Nigeria, implying that the enzyme was not associated with total SOM-pools and microbial nutrient turnover. In contrast, several other authors (SPARLING et al., 1986; LoPEZ-HeRnANDEZ et al., 1989; DiCK et al., 1988; Deng and TABATABAI, 1997; DIEKMANN, 1997) found positive correlations between acid phosphatase activities and soil organic C and SMB. SKUJINS (1976) reported that the activity of acid phosphatase was independent whereas SPARLING et al. (1986) stated that acid phosphatase activity was significantly correlated with SIR-biomass (substrate-induced-respiration-method) but not with ATP-biomass (ATP-method). CHHONKAR and TARAFDAR (1984), HÄUSSLING and MARSCHNER (1989), and RASTIN et al. (1988), on the other hand, found significant positive correlations between SMB and acid phosphatase activity under various conditions.

No significant correlations were obtained between alkaline phosphatase activity and maize yield parameters and P uptake in maize plants at harvest in October 1995. However, alkaline phosphatase activity was significantly correlated with CEC ( $r=0.83)$, exchangeable $\mathrm{Ca}(\mathrm{r}=0.83)$, organic $\mathrm{C}(\mathrm{r}=0.82)$ and organic $\mathrm{P}(\mathrm{r}=0.80)$ content (Annex, Table 54). Relatively strong correlations were found with exchangeable $\mathrm{Mg}$ $(\mathrm{r}=0.76)$, total $\mathrm{N}(\mathrm{r}=0.74)$, and soil $\mathrm{pH}(\mathrm{r}=0.71)$. Only a weak correlation was obtained between alkaline phosphatase activity and soil inorganic $\mathrm{P}$ content $(\mathrm{r}=0.23)$. The positive correlations of alkaline phosphatase with $\mathrm{Ca}$ and soil $\mathrm{pH}$ indicate that activity is dependent on $\mathrm{pH}$ conditions in soils. Strong correlations of alkaline phosphatase activities with SOM and pH were also reported by FRANKENBERGER and DiCK (1983), Dick et al. (1988), JORDAN et al. (1995) and DENG and TABATABAI (1997). The relationships found for alkaline phosphatase with inorganic and organic $\mathrm{P}$ pools was not in line with results from IITA, in southern Nigeria, where no consistent correlation was observed (WICK, 1997). A lack of correlation with soil inorganic and organic P content under field conditions was also reported by SPEIR and COWLING (1991) and ADAMS (1992).

The ß-glucosidase activity was significantly correlated with other soil components, such as organic $\mathrm{C}(\mathrm{r}=0.78)$, total $\mathrm{N}(\mathrm{r}=0.71)$, organic $\mathrm{P}(\mathrm{r}=0.76), \mathrm{CEC}(\mathrm{r}=0.73), \mathrm{Mg}(\mathrm{r}=0.71)$ and exchangeable $\mathrm{Ca}(\mathrm{r}=0.68)$ content (Annex, Table 54). 
The correlations with soil $\mathrm{pH}(\mathrm{r}=0.50)$ and available $\mathrm{Zn}(\mathrm{r}=0.47)$ were less strong. A similar positive correlation of B-glucosidase with soil organic $\mathrm{C}$ was reported by Deng and TABAtabai (1996), Wick (1997) and DiekmanN (1997), and reflect the involvement of the enzyme in the carbon cycle (DENG and TABATABAI, 1996). The relatively good relationships we found for $\mathrm{B}$-glucosidase with total $\mathrm{N}$, cations and organic $\mathrm{P}$ reveal that nutrient dynamics in these soils are closely intercorrelated.

Only in the highly degraded CH 2 field, correlations were found between B-glucosidase activity and plant parameters (Table 27). The results suggest that at $\mathrm{CH} 2$, soil management practices that influence maize production and uptake of $\mathrm{N}, \mathrm{P}, \mathrm{K}, \mathrm{Mg}$, and $\mathrm{Zn}$ in maize also affect soil B-glucosidase activity and thus SOM cycling. These findings support results presented by DIEKMANN (1997) who reported that B-glucosidase activity was closely correlated to crop yield in soils in eastern Amazonia. It is suggested that in this nutrient-poor soil, plant production competes with microbial growth for available nutrients in the soil. Severe nutrient limitation, such as for $\mathrm{N}, \mathrm{P}$ and $\mathrm{Zn}$ was resulting in reduced $\beta$-glucosidase activity and thus indicating lower carbon cycling in these soils. In the highly degraded soil ß-glucosidase activity was not only substantially reduced but also fluctuations were significantly lower than at the less degraded $\mathrm{CH} 1$ site. The importance of $\beta$-glucosidase in mineralization and carbon cycling was implied by relatively good correlations with microbial biomass and the other soil enzymes.

Table 27: Correlation coefficients (r) of soil B-glucosidase activity of the $0-30 \mathrm{~cm}$ soil layer at the beginning of the third season (June 1995) with maize biomass production and nutrient uptake rates in October 1995. Location: CH 2 (degraded).

\begin{tabular}{llll}
\hline Soil B-glucosidase activity vs & $\mathrm{r}$ & $p$ & $\mathrm{n}$ \\
\hline Maize biomass production & 0.41 & $* *$ & 50 \\
N uptake & 0.44 & $* * *$ & 50 \\
P uptake & 0.40 & $* *$ & 50 \\
K uptake & 0.29 & $*$ & 50 \\
Ca uptake & 0.38 & $* *$ & 50 \\
Mg uptake & 0.44 & $* *$ & 50 \\
Zn uptake & 0.48 & $* * *$ & 50 \\
\hline
\end{tabular}


As it was observed for soil phosphatase and $\beta$-glucosidase activities also protease activity was significantly and positively correlated to all other soil parameters determined (Annex, Table 54). However, the correlations were not very strong. From the soil chemical parameters the strongest correlation was found with organic $\mathrm{P}(\mathrm{r}=0.60)$, total $\mathrm{N}(\mathrm{r}=0.55)$, organic C $(r=0.53)$, CEC $(r=0.52)$, exchangeable $\mathrm{Ca}(\mathrm{r}=0.52)$ and exchangeable $\mathrm{Mg}(\mathrm{r}=0.50)$. Regarding the microbial parameters the strongest correlation was obtained with 3 -glucosidase activity $(\mathrm{r}=0.66)$. Correlations with acid $(\mathrm{r}=0.57)$ and alkaline phosphatase activity $(r=0.57)$ as well as with microbial $\mathrm{C}(\mathrm{r}=0.57)$ were somewhat lower. Some authors reported a strong correlation of SOM and total $\mathrm{N}$ with protease activity (LOLL and BOLLAG, 1983; FrASER et al., 1995). On the contrary, BONMATI et al. (1991), for instance, reported a weak correlation between protease activity and total soil $\mathrm{N}$ in soils from a five year old grass-legume pasture in Italy. DOMSCH et al. (1979) and FRANKENBERGER and DICK (1983) found similar relationships between $\mathrm{C}_{\mathrm{mic}}$ and protease activity. ASMAR et al. (1995) and BADALUCCO et al. (1996) reported a positive correlation between microbial biomass and protease activity. However, SARATCHANDRA et al. (1984) did not find a significant relationship of protease activity with biomass carbon content.

In general, protease activity appears to be important to the solubility of soil organic $\mathrm{N}$ (ALEF and NANNIPIERI, 1995a). Most of the N present in soil is considered to be of organic nature and represents an important nutrient reservoir. Protein- $\mathrm{N}$ is the major form of soil organic $\mathrm{N}$ where plant residues and manure are the only sources available. Thus, soil proteases are considered to reflect the proteolytic potential of a soil and indicate protein degradation capacity. Protease activity was found to be positively correlated with soil microbial biomass and soil enzyme activities. Thus, the main mineralization processes in soil organic $\mathrm{N}$ cycling provide increased substrate and available $\mathrm{N}$ for microbial growth and activity. Due to higher microbial activity, stored nutrients will be subsequently released by decomposition of the organic residues which is increasing nutrient availability in the soil and the system's internal cycling efficiency.

Lower protease activity observed in the degraded soil might be a combined effect of limited growth of heterotrophic microorganisms due to limited nutrients and energy but may be also due to vulnerability of soluble extracellular protease to proteolytic enzymes, and adsorption by clay and SOM. Thus, the lower protease activity at the degraded $\mathrm{CH} 2$ site could be interpreted as reduced protein degradation capacity at this site. 


\subsubsection{Microbiological parameters as soil quality indices}

The microbiological soil properties varied widely with sampling date and partly with fertilizer treatment. All parameters were able to distinguish between the degraded and non-degraded site with generally lower SMB and enzyme activities but also lower seasonal variation at the degraded site.

Fertilization effects increased from year to year. Partly, treatment effects were already visible in the second cropping season. The addition of mineral and/or organic fertilizer increased maize production also resulting in higher amounts of crop residues left in the field. Subsequently, SMB and enzyme activities increased on higher substrate availability. Continued application of cotton seed waste further promoted soil enzyme activities.

Cultivation of soils, besides affecting soil chemistry and structure, also affects soil biology. Results from the study showed that savanna soils without mineral fertilizer or organic amendments have a reduced potential to accomplish the important soil function of nutrient cycling. Mineral fertilizer in combination with cotton seed waste increased the nutrient status of the soil, as well as biological and biochemical characteristics which improved maize yield and nutrient uptake. Microbiological soil characteristics were more sensitive to treatment effects and seasonal changes in the soil than soil organic $\mathrm{C}$, total $\mathrm{N}$ and organic $\mathrm{P}$, especially in the highly degraded soil. The SMB is a small but labile source of major nutrients (C, N, P, and S). However, SMB as such is no measure of microbial activity.

Measurements of SMB can be used as an early indication of the response by the SOM cycle to changes of soil management. Better indices of SMB activity include microcalorimetry, respiration rates, measurements of ATP in soil extracts and enzyme activities (DICK, 1992).Generally, soil enzyme activities have been used as indices of microbial activity and nutrient cycling in soil. They represent the biological activity of a soil and reflect dynamics of soil nutrient cycling and energy transfer. However, one enzyme is unlikely to reflect the overall state of nutrients and microbial dynamics.

The use of a single soil property does not afford a reliable soil quality index, because all soil parameters are closely interrelated. Soil microbial biomass and soil enzyme activities were correlated with SOM content, but also with other soil components such as CEC and exchangeable $\mathrm{Ca}$ and $\mathrm{Mg}$. The observed significant correlations among enzyme activities suggest that organic and mineral input of nutrients have similar effects on the enzymes involved in $\mathrm{C}, \mathrm{N}$ and $\mathrm{P}$ cycling in savanna soils. 


\section{$5.4 \quad$ Mineral nitrogen}

Dynamics of $\mathrm{NH}_{4}{ }^{+}, \mathrm{NO}_{3}{ }^{-}$and $\mathrm{N}_{\text {min }}$ in the top soil $(0-30 \mathrm{~cm})$ from the treatments (All), (All org), (-N), (org), and the control from June 1993 to October 1995 are presented in Table 55 and Table 56 in the Annex. Additional soil samples were taken in the soil profile $(0-30,30-60$ and $60-90 \mathrm{~cm})$ at intervals of three weeks during the growth period in the third season from June 1995 to October 1995. Statistical analysis of $\mathrm{NH}_{4}{ }^{+}, \mathrm{NO}_{3}{ }^{-}$and $\mathrm{N}_{\text {min }}$ across soil layers are shown in the Annex (Table 57 - Table 62). Typical dynamics of $\mathrm{NH}_{4}{ }^{+}$ and $\mathrm{NO}_{3}{ }^{-}$in the soil profile as affected by fertilizer are shown in Figure 5 and Figure 6.

\subsubsection{Soil ammonium content during three years from June 1993 to October 1995}

Dynamics of $\mathrm{NH}_{4}{ }^{+}$content in the surface soil $(0-30 \mathrm{~cm})$ during three years of sequential maize cropping are presented in Table 55 in the Annex. At the initial stage (June 1993) soil $\mathrm{NH}_{4}{ }^{+}$content was substantially higher at $\mathrm{CH} 1$ (non-degraded) than at $\mathrm{CH} 2$ (degraded).

At $\mathrm{CH}$ 1, soil $\mathrm{NH}_{4}{ }^{+}$content declined from June 1993 to October 1995. At the end of the second cropping season (October 1994) and at the beginning of the third season (June 1995) soil $\mathrm{NH}_{4}^{+}$content was significantly lower in the (-N) and the control treatment. However, at the end of the third season (October 1995) soil $\mathrm{NH}_{4}{ }^{+}$content was not significantly different among treatments. At $\mathrm{CH} 2, \mathrm{NH}_{4}{ }^{+}$values fluctuated between $1-10 \mathrm{~kg} \mathrm{~N} \mathrm{ha}^{-1}$ during the experiment. In the third year mineral (All) and a combined mineral and organic fertilization (All org) increased soil $\mathrm{NH}_{4}{ }^{+}$content significantly as compared to the (-N) and control treatment. At the end of the third season the $\mathrm{NH}_{4}{ }^{+}$content was lowest in the (-N) and the control treatment with values of only $1 \mathrm{~kg} \mathrm{~N} \mathrm{ha}^{-1}$.

Ammonium levels can be seasonally important in tropical soils with a pronounced dry period (WONG and NORTCLIFF, 1995 as cited by BARRIOS et al., 1998). The conversion of $\mathrm{NH}_{4}{ }^{+}$to $\mathrm{NO}_{3}{ }^{-}$(nitrification) is more sensitive to soil water deficit than the formation of $\mathrm{NH}_{4}{ }^{+}$(ammonification). Appreciable $\mathrm{NH}_{4}{ }^{+}$can accumulate during the dry season, and may not have nitrified at the onset of the cropping season. Following soil wetting there is a rapid nitrification. This could be the reason for higher $\mathrm{NH}_{4}{ }^{+}$at the non-degraded $\mathrm{CH} 1$ site at the beginning of the experiments. With the onset of the rainy season, $\mathrm{NH}_{4}{ }^{+}$declined and $\mathrm{NO}_{3}{ }^{-}$ increased during the first cropping season. These findings are in line with BARRIOS et al., (1998) who reported higher $\mathrm{NH}_{4}{ }^{+}$presumably due to the absence of nitrification in soils in Zambia and with results from savanna soils in northern Nigeria (WEBER et al., 1995). 


\subsubsection{Dynamics of ammonium $\mathrm{N}$ in the soil profile $(0-90 \mathrm{~cm})$ under maize}

Soil $\mathrm{NH}_{4}{ }^{+}$content was usually low at both sites during the third year. Only samples of fertilized plots showed increased $\mathrm{NH}_{4}{ }^{+}$peaks (Figure 5). The general pattern of soil $\mathrm{NH}_{4}{ }^{+}$content did not vary between sites. However, the $\mathrm{NH}_{4}{ }^{+}$peaks in the degraded $\mathrm{CH} 2$ soil were smaller: by $34 \%$ for treatment (All) and by $30 \%$ for (All org).

At the beginning of the third season (June 1995) there were no differences in $\mathrm{NH}_{4}{ }^{+}$content between the two soils in the top soil $(0-30 \mathrm{~cm})$. In the $\mathrm{N}$-fertilized plots, the $\mathrm{NH}_{4}{ }^{+}$content fluctuated strongly. After urea application (05. 07. 1995) in the treatments (All) and (All org), soil $\mathrm{NH}_{4}{ }^{+}$content increased following urea hydrolysis in the surface soil. The subsequent decrease of soil $\mathrm{NH}_{4}{ }^{+}$with time can be explained by declining urea hydrolysis, but also by nitrification and uptake of $\mathrm{NH}_{4}-\mathrm{N}$ in plant and microbial biomass. With organic fertilizer (org), soil $\mathrm{NH}_{4}{ }^{+}$content increased slightly due to decomposition of cotton seed waste. In the control and (-N) treatment at $\mathrm{CH} 1$ soil $\mathrm{NH}_{4}{ }^{+}$fluctuated on a very low level due to ammonification of inherent soil organic $\mathrm{N}$, roots and crop residues by heterotrophic microbes. At $\mathrm{CH} 2$, without fertilizer application $\mathrm{NH}_{4}{ }^{+}$decreased in the top soil.

Fertilizer $\mathrm{N}$ recovery in the soil profile $(0-90 \mathrm{~cm})$ was calculated on the basis of soil $\mathrm{NH}_{4}{ }^{+}$ content at the first peak (fertilized - control) and expressed as percentage of applied urea $\mathrm{N}$. In treatment (All), at $\mathrm{CH} 1$ about $69 \%$ and at $\mathrm{CH} 2$ about $59 \%$ of fertilizer-N was recovered. From the combined mineral and organic fertilizer (All org) about $48 \%$ was recovered at $\mathrm{CH} 1$ and about $44 \%$ at $\mathrm{CH} 2$. N-Recovery from organically fertilized plots was $37 \%$ at $\mathrm{CH} 1$ and $47 \%$ at $\mathrm{CH} 2$. Within four weeks after the peak, soil $\mathrm{NH}_{4}{ }^{+}$content decreased and until mid August $\mathrm{NH}_{4}{ }^{+}$released from urea hydrolysis was probably nitrified.

After the second rate of urea was applied (12.08. 1995) a second but much lower $\mathrm{NH}_{4}^{+}$ peak followed in the beginning of September. Towards the end of the season, soil $\mathrm{NH}_{4}^{+}$ content declined rapidly and in October 1995 the $\mathrm{NH}_{4}{ }^{+}$content in both soils were approaching values of about $4 \mathrm{~kg} \mathrm{~N} \mathrm{ha}^{-1}$ at $\mathrm{CH} 1$ and $3 \mathrm{~kg} \mathrm{~N} \mathrm{ha}^{-1}$ at $\mathrm{CH} 2$ in the top soil.

In the $30-60 \mathrm{~cm}$ horizon soil $\mathrm{NH}_{4}{ }^{+}$content was higher at $\mathrm{CH} 1$ at the beginning of the third season (Figure 5). Until mid July, the $\mathrm{NH}_{4}{ }^{+}$content at $\mathrm{CH} 1$ decreased followed by an increase until August, due to the first urea application. Thereafter, $\mathrm{NH}_{4}{ }^{+}$decreased again. After the second dose of urea, again $\mathrm{NH}_{4}{ }^{+}$slightly increased until mid September at $\mathrm{CH} 1$. 

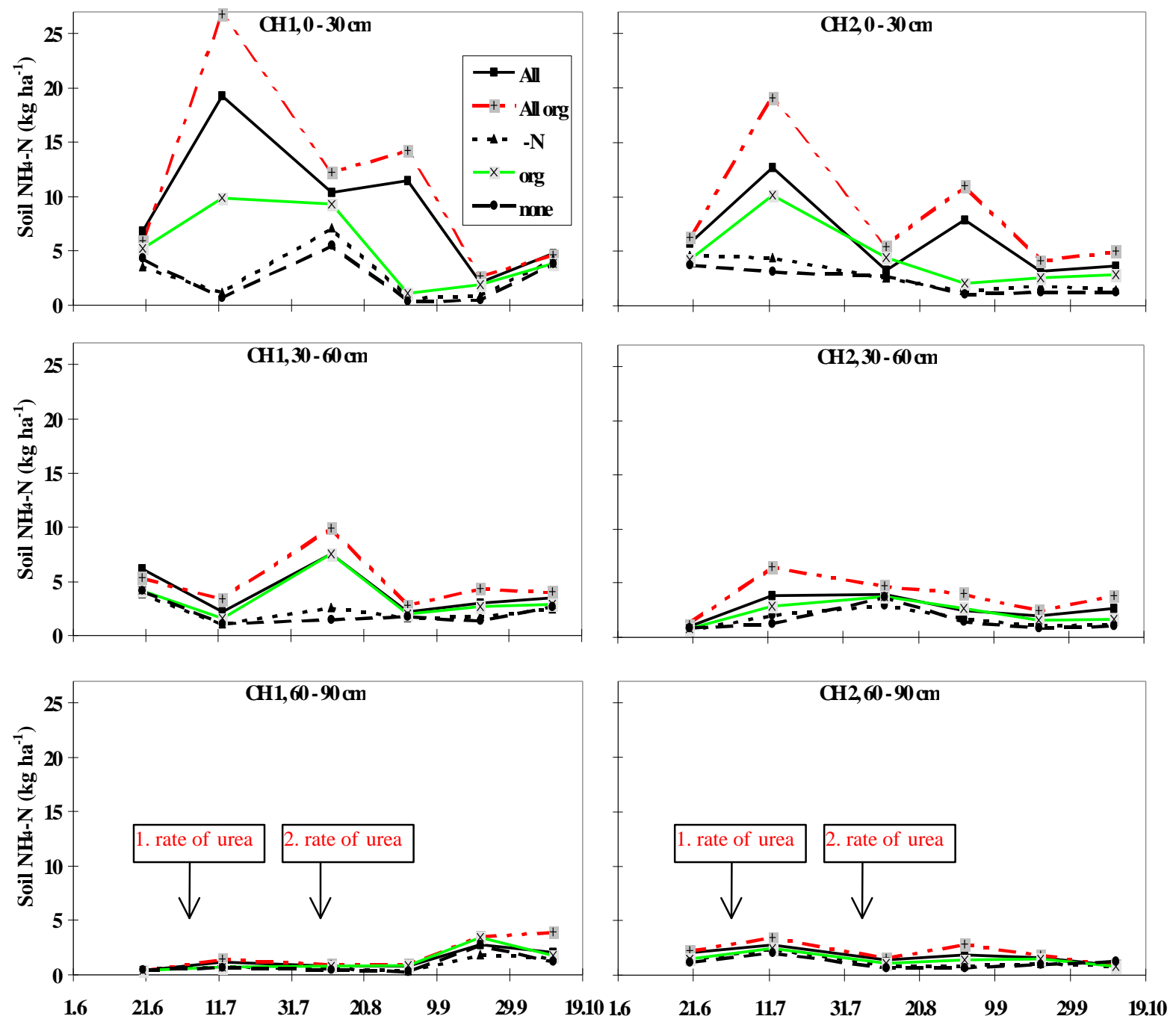

Figure 5: Dynamics of soil ammonium $\mathrm{N}$ content in the soil profile under maize from June 1995 to October 1995 in soil layers from $0-30 \mathrm{~cm}, 30-60 \mathrm{~cm}$, and 60 $90 \mathrm{~cm}$. Location $\mathrm{CH} 1$ (not degraded) and $\mathrm{CH} 2$ (degraded).

At $\mathrm{CH} 2$, in the $30-60 \mathrm{~cm}$ soil layer $\mathrm{NH}_{4}{ }^{+}$increased after urea application and peaked in mid July. Thereafter, the $\mathrm{NH}_{4}{ }^{+}$content decreased until the end of the season. At both sites the $\mathrm{NH}_{4}{ }^{+}$content was higher in the $\mathrm{N}$-fertilized plots as compared to the control and the (-N) treatment. The $\mathrm{NH}_{4}{ }^{+}$peaks in the $30-60 \mathrm{~cm}$ soil layers of the fertilized plots indicated leaching of $\mathrm{NH}_{4}{ }^{+}$into deeper soil horizons at both sites. However, the increase in $\mathrm{NH}_{4}{ }^{+}$content in the lower horizons could only account for a small part of the $\mathrm{NH}_{4}{ }^{+}$ which disappeared from the top soil. At the $60-90 \mathrm{~cm}$ horizon, soil $\mathrm{NH}_{4}{ }^{+}$content remained almost constant at a low level without significant treatment effects and no differences between sites (see Annex Table 57 and Table 58). 
HÄRDTER (1989) stated that the $\mathrm{NH}_{4}{ }^{+}$content of upland soils at Nyankpala is low. He reported similar $\mathrm{NH}_{4}{ }^{+}$content in soil profiles following urea application $\left(80 \mathrm{~kg} \mathrm{~N} \mathrm{ha}^{-1}\right)$. In contrast to our results, no downward movement of $\mathrm{NH}_{4}{ }^{+}$occurred in his experiments. WARREN et al. (1997) recorded similar values of $\mathrm{NH}_{4}{ }^{+}$content for soils of semi-arid Kenya. However, soil $\mathrm{NH}_{4}{ }^{+}$concentrations remained nearly constant without differences between sorghum and fallow plots or between fertilized and unfertilized plots or between different sampling dates.

\subsubsection{Soil nitrate content during three years from June 1993 to October 1995}

In June 1993, preseason $\mathrm{NO}_{3}{ }^{-}$content was higher at the degraded $\mathrm{CH} 2$ site $\left(20 \mathrm{~kg} \mathrm{~N} \mathrm{ha}^{-1}\right)$ than at the non-degraded $\mathrm{CH} 1$ site $\left(12 \mathrm{~kg} \mathrm{~N}^{-1}\right)$. This initial difference between the two sites should be devoted to differences in soil management and cropping history as affected by the preceding dry season.

At $\mathrm{CH} 1$, in all treatments the $\mathrm{NO}_{3}{ }^{-}$content increased from June 1993 to October 1995. However, soil $\mathrm{NO}_{3}{ }^{-}$content remained lowest in the $(-\mathrm{N})$ and in the control treatments. At $\mathrm{CH} 2$, soil $\mathrm{NO}_{3}{ }^{-}$content in the (-N) and in the control plots decreased until October 1995.

Without fertilizer the fluctuations can be attributed to SOM mineralization and to degradation of weed biomass and crop residues from the previous season. Fluctuation of $\mathrm{NO}_{3}{ }^{-}$ across years and sites were between 13 and $60 \mathrm{~kg} \mathrm{~N} \mathrm{ha}^{-1}$ in the top soil. Since $\mathrm{N}$ amounts in above ground weed biomass (Annex, Table 50) and crop residues (Annex, Table 48) were low, the increase in the control and (-N) treatments might be interpreted mainly as a result of mobilizing organic soil $\mathrm{N}$ reserves. Among the (-N) treatments and the controls there were no significant differences. This indicated that without $\mathrm{N}$ fertilizer input, soil $\mathrm{NO}_{3}{ }^{-}$ content remained at a low level, which is reflecting low inherent soil $\mathrm{NO}_{3}{ }^{-}$supplying capacity. Fertilizer application significantly increased soil $\mathrm{NO}_{3}{ }^{-}$content due to higher nitrification activity after the second and third season as compared to the (-N) and control plots.

\subsubsection{Dynamics of nitrate $\mathrm{N}$ in the soil profile $(0-90 \mathrm{~cm})$ under maize}

Mineral fertilizer use during the previous two experimental years resulted in a higher $\mathrm{NO}_{3}{ }^{-}$ content in the topsoil at the beginning of the third season (Figure 6). However, there were only slight differences in $\mathrm{NO}_{3}{ }^{-}$content between the two fields. The lowest preseason $\mathrm{NO}_{3}{ }^{-}$ content was found at both sites in the control and in the $(-\mathrm{N})$ treatment. 

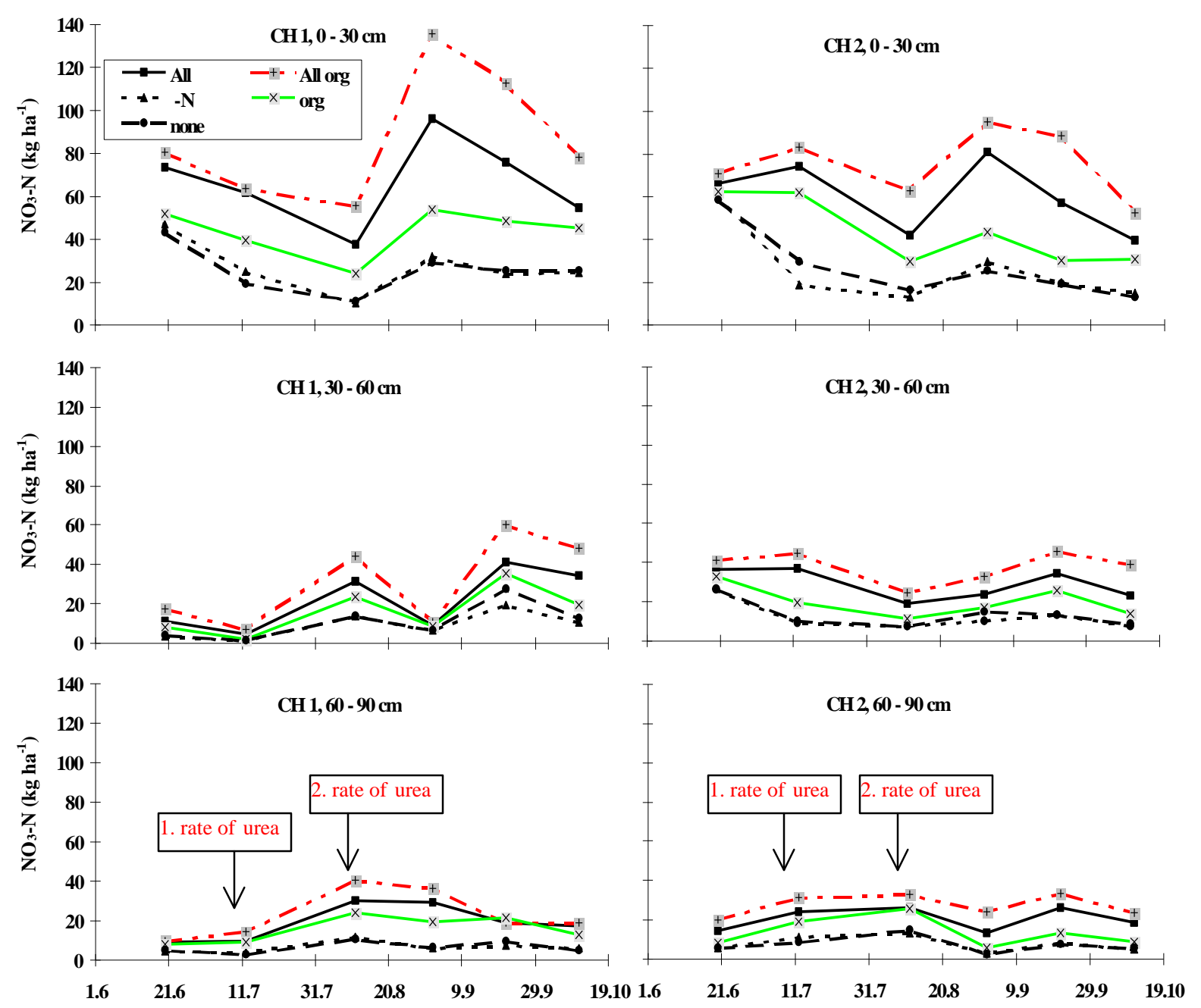

Figure 6: Dynamics of soil nitrate $\mathrm{N}$ content under maize from June 1995 until October 1995 in soil layers from $0-30 \mathrm{~cm}, 30-60 \mathrm{~cm}$, and $60-90 \mathrm{~cm}$. Location CH 1 (not degraded) and $\mathrm{CH} 2$ (degraded).

Differences among fertilizer treatments were more pronounced at the non-degraded $\mathrm{CH} 1$ site. Here, preseason $\mathrm{NO}_{3}{ }^{-}$content ranged from $52 \mathrm{~kg} \mathrm{~N}$ ha $^{-1}$ with cotton seed waste (org) to $74 \mathrm{~kg} \mathrm{~N} \mathrm{ha}^{-1}$ with mineral fertilizer (All) and was highest with $81 \mathrm{~kg} \mathrm{~N} \mathrm{ha}^{-1}$ after mineral fertilizer plus cotton seed waste (All org). Until mid of August, soil $\mathrm{NO}_{3}{ }^{-}$decreased for all treatments. At the degraded $\mathrm{CH} 2$ site, $\mathrm{NO}_{3}{ }^{-}$content ranged from $62 \mathrm{~kg} \mathrm{~N} \mathrm{ha}^{-1}$ (org) to 66 $\mathrm{kg} \mathrm{N} \mathrm{ha}^{-1}$ (All) with the highest value of $71 \mathrm{~kg} \mathrm{~N} \mathrm{ha}^{-1}$ (All org) at the beginning of the third season. Soil $\mathrm{NO}_{3}{ }^{-}$increased slightly up to $83 \mathrm{~kg} \mathrm{~N} \mathrm{ha}^{-1}$ in the treatments (All) and (All org).

With organic fertilizer (org), $\mathrm{NO}_{3}{ }^{-}$content was stable until mid July and then decreased until mid August. From mid August until September at both sites, $\mathrm{NO}_{3}{ }^{-}$increased due to 
the second rate of urea application. This $\mathrm{NO}_{3}{ }^{-}$peak indicates good recovery of fertilizer $\mathrm{N}$ in the soil. The peak at $\mathrm{CH} 2$ was less pronounced. Until October, $\mathrm{NO}_{3}{ }^{-}$in the topsoil was depleted probably as a consequence of a high $\mathrm{N}$ uptake by maize plants, microbial immobilization and downward movement of $\mathrm{NO}_{3}{ }^{-}$into deeper layers. At the end of the third season, the highest $\mathrm{NO}_{3}{ }^{-}$values were reached in the treatment (All org) followed by the complete fertilized treatment (All) and the organic fertilizer treatment (org). These high values indicated $\mathrm{N}$ supply in excess of demand. Nitrate content was generally higher in the non-degraded $\mathrm{CH} 1$ soil than at $\mathrm{CH} 2$ soil after urea application.

In the $30-60 \mathrm{~cm}$ and in the $60-90 \mathrm{~cm}$ horizon $\mathrm{NO}_{3}{ }^{-}$content increased only in the fertilized plots. A downward movement of $\mathrm{NO}_{3}^{-}$(leaching) was indicated since the decrease in the top soil $(0-30 \mathrm{~cm})$ coincided well with the increase in the deeper soil layers after fertilizer applications.

In the $30-60 \mathrm{~cm}$ horizon $\mathrm{NO}_{3}{ }^{-}$peaks were higher at $\mathrm{CH} 1$, with one peak at the beginning of August and a second peak in mid September. The higher $\mathrm{NO}_{3}{ }^{-}$content in the subsoil at the end of the rainy season (October 1995) indicated that $\mathrm{NO}_{3}{ }^{-}$leached from the topsoil and could not be recovered by the maize plants.

Our results confirmed similar patterns of $\mathrm{NO}_{3}{ }^{-}$dynamics found by HÄRDTER (1989) in the same area. He reported similar values of $\mathrm{NO}_{3}{ }^{-}$accumulation in the subsoil at the end of the rainy season, confirming that $\mathrm{N}$ application increased $\mathrm{NO}_{3}{ }^{-}$leaching losses. A similar pattern of variability of $\mathrm{NO}_{3}{ }^{-}$concentrations during the whole season and of decline of $\mathrm{NO}_{3}{ }^{-}$ concentrations during the season was observed in the soil profile in savanna soils in northern Nigeria (WEBER et al., 1995). They attributed differences between years to their different rainfall pattern. Possible causes for the decrease in $\mathrm{NO}_{3}{ }^{-}$at $\mathrm{CH} 2$ in the third season could be that $\mathrm{NO}_{3}{ }^{-}$might have been lost from the system by being utilized by maize crops and microrganisms, or leached into deeper soil layers. WEBER et al. (1995) attributed the high variability of $\mathrm{NO}_{3}{ }^{-}$concentrations during the season to changes in microbial activity.

Generally, $\mathrm{NO}_{3}{ }^{-}$concentrations in the top soil change quickly because they reflect the net effect of

(i) inputs from SOM mineralization, fertilizers and the atmosphere and

(ii) removal by plant uptake, microbial immobilization, leaching and gaseous loss. Nitrate does not accumulate if the rate of consumption is equal to or greater than its rate of production. 


\subsubsection{The use of preseason $\mathrm{NH}_{4}{ }^{+}, \mathrm{NO}_{3}{ }^{-}$and $\mathrm{N}_{\min }$ as a measure of plant available $\mathrm{N}$}

There was no correlation of preseason soil $\mathrm{NH}_{4}{ }^{+}, \mathrm{NO}_{3}{ }^{-}$and $\mathrm{N}_{\min }$ with organic carbon $\left(\mathrm{C}_{\text {org }}\right)$, total $\mathrm{N}, \mathrm{C} / \mathrm{N}$ ratio and $\mathrm{pH}$ in the top layer $(0-30 \mathrm{~cm})$ at the beginning of the third season (Annex, Table 63).

Preseason soil $\mathrm{NH}_{4}{ }^{+}, \mathrm{NO}_{3}{ }^{-}$and $\mathrm{N}_{\text {min }}$ at maize planting in June 1995 significantly correlated with grain yield and $\mathrm{N}$ uptake in total maize biomass for both soils (Table 28). Maize yield and $\mathrm{N}$ uptake was better related to preseason $\mathrm{NO}_{3}{ }^{-}$than to preseason $\mathrm{NH}_{4}{ }^{+}$. Mineral $\mathrm{N}$ followed similar trends to those of $\mathrm{NO}_{3}{ }^{-}$because it largely comprised $\mathrm{NO}_{3}{ }^{-}$. The relationship between grain yield and $\mathrm{N}$ uptake and either $\mathrm{NH}_{4}^{+}, \mathrm{NO}_{3}^{-}$or $\mathrm{N}_{\text {min }}$ improved when a greater soil depth was considered. The results indicate the importance of using $\mathrm{N}_{\min }$ as a measure of plant available $\mathrm{N}$. However, using preseason $\mathrm{N}_{\text {min }}$ improved the relationships as compared to $\mathrm{NO}_{3}{ }^{-}$alone only marginally. Therefore, residual $\mathrm{NO}_{3}{ }^{-}$was adequate as a measurement of available soil $\mathrm{N}$ in the study soils.

BARRIOS et al. (1998) reported that preseason soil $\mathrm{NH}_{4}{ }^{+}, \mathrm{NO}_{3}{ }^{-}$and $\mathrm{N}_{\text {min }}$ significantly correlated with grain yield in similar soils and climate conditions in Zambia. WEBER et al. (1995) found that soil $\mathrm{NO}_{3}{ }^{-}$was the only soil-related characteristic which closely related to maize grain yields in farmers' fields in the Guinea savanna of Nigeria. In soils in Kenya, residual inorganic $\mathrm{N}$ in the soil profile was a suitable measure when determined at about the time of crop planting, as $\mathrm{NO}_{3}{ }^{-}$losses and $\mathrm{N}$ mineralization during crop growth are small (MOROKO et al., 1998).

Soil $\mathrm{NO}_{3}{ }^{-}$has been widely used as a measure of $\mathrm{N}$ availability because it is strongly influenced by soil management, has a good reproducibility, and correlates with maize grain yield in temperate soils (STANFORD, 1982, KUO et al. 1996) and in the tropics (STEPHENS 1967 as cited by MoroKo et al., 1998; WeBer et al, 1995). However, it has to be considered that factors contributing to differences in $\mathrm{NH}_{4^{-}}$and $\mathrm{NO}_{3}$-dynamics depend partially on rainfall pattern (WEBER et al., 1995). As reported in the previous chapters, nitrification is more sensitive to soil water deficit than ammonification. Ammonium can be seasonally accumulated in tropical soils with a long dry period with subsequently rapid nitrification following soil wetting (WONG and NORTCLIFF, 1995 as cited by BARRIOS et al., 1998). Thus, the strong impact of rainfall might limit the predictability of maize grain yield by soil $\mathrm{NO}_{3}{ }^{-}$alone. 
Table 28: Correlation coefficients ( $\mathrm{r}$ ) of preseason soil $\mathrm{NH}_{4}{ }^{+}, \mathrm{NO}_{3}{ }^{-}$and $\mathrm{N}_{\min }$ at the beginning of the third season (20.06. 1995) with grain yield and $\mathrm{N}$ uptake in total maize biomass (harvest October 1995). Locations: CH 1, CH 2.

\begin{tabular}{|c|c|c|c|c|}
\hline \multirow[b]{2}{*}{ Parameter } & \multicolumn{2}{|c|}{ CH 1 (non-degraded) } & \multicolumn{2}{|c|}{ CH 2 (degraded) } \\
\hline & grain yield & $\begin{array}{l}\mathrm{N} \text { uptake in } \\
\text { total maize biomass }\end{array}$ & grain yield & $\begin{array}{l}\mathrm{N} \text { uptake in } \\
\text { total maize biomass }\end{array}$ \\
\hline $\mathrm{NH}_{4}{ }^{+}(0-30 \mathrm{~cm})$ & $0.61 * *$ & $0.57 * *$ & $0.51 * *$ & $0.53 * *$ \\
\hline $\mathrm{NO}_{3}^{-}(0-30 \mathrm{~cm})$ & $0.84 * * *$ & $0.85 * * *$ & $0.58 * *$ & $0.50 *$ \\
\hline$N_{\min }(0-30 \mathrm{~cm})$ & $0.85 * * *$ & $0.86^{*}$ & $0.61 * * *$ & $0.55 * *$ \\
\hline $\mathrm{NH}_{4}{ }^{+}(0-90 \mathrm{~cm})$ & $0.73 * * *$ & $0.70 * * *$ & $0.63^{* * *}$ & $0.68 * * *$ \\
\hline $\mathrm{NO}_{3}^{-}(0-90 \mathrm{~cm})$ & $0.89 * * *$ & $0.90 * * *$ & $0.82 * * *$ & $0.77 * * *$ \\
\hline$N_{\min }(0-90 \mathrm{~cm})$ & $0.90 * * *$ & $0.90 * * *$ & $0.83 * * *$ & $0.78 * *$ \\
\hline
\end{tabular}

The high variability in soil $\mathrm{NO}_{3}{ }^{-}$found in on-farm trials in West Africa savannas (WEBER et al, 1995), further raises concern whether soil $\mathrm{NO}_{3}{ }^{-}$alone would have the required predictive capacity for $\mathrm{N}$ response on farmers' fields in tropical soils. Moreover, the use of residual $\mathrm{NO}_{3}{ }^{-}$as a measure of plant available $\mathrm{N}$ in tropical soils has the potential limitation of not including $\mathrm{NH}_{4}{ }^{+}$and readily mineralizable soil organic $\mathrm{N}$, which can be an important source of $\mathrm{N}$ in subsistence agricultural systems with low fertilizer use.

Soil $\mathrm{NO}_{3}{ }^{-}$in the profile fluctuated strongly in the deeper soil horizons dependent on sampling time in the $(-\mathrm{N})$ and control plots indicating moderate leaching of $\mathrm{NO}_{3}{ }^{-}$ even without $\mathrm{N}$ fertilizer application. Therefore soil $\mathrm{NO}_{3}{ }^{-}$content across the soil profile $(0-90 \mathrm{~cm})$ is recommended as a more appropriate measure of plant available $\mathrm{N}$ than using $\mathrm{NO}_{3}{ }^{-}$content of the top soil. 


\subsection{6 $\quad \mathrm{N}_{\min }$-balance}

In order to compare the two sites and to asses the effects of the different treatments in terms of $\mathrm{N}$ loss or gain during maize growth, the $\mathrm{N}$ balance in the soil profile to a depth of $90 \mathrm{~cm}$ was computed for the third season (1995) using $\mathrm{N}$ uptake of maize, the amount of fertilizer $\mathrm{N}$ and soil $\mathrm{N}_{\min }$ content at the beginning and at the end of the season according the following equation: $\Delta \mathrm{N}=\left(\mathrm{N}_{\mathrm{up}}+\mathrm{N}_{\min (05.10 .95)}\right)-\left(\mathrm{N}_{\text {fert }}+\mathrm{N}_{\min (20.06 .95)}\right)$

$\Delta \mathrm{N}: \mathrm{N}_{\min }$-balance ( $\mathrm{N}$ loss or gain in the system);

$\mathrm{N}_{\text {up }}$ : above ground $\mathrm{N}$ uptake in maize at harvest in 1995;

$\mathrm{N}_{\min (05.10 .95)}: \mathrm{N}_{\min }$ in the soil profile to a depth of $90 \mathrm{~cm}$ measured at maize harvest;

$\mathrm{N}_{\text {fert }}: \mathrm{N}$ fertilizer added to the system;

$\mathrm{N}_{\min (20.06 .95)}: \mathrm{N}_{\min }$ in the soil profile to a depth of $90 \mathrm{~cm}$ at maize planting.

The $\mathrm{N}_{\min }$-balance under maize showed contrasting trends for the two fields (Table 29). A positive $\mathrm{N}_{\min }$-balance was calculated for all treatments at the non-degraded $\mathrm{CH} 1$ site. Even, without $\mathrm{N}$ fertilizer application $\mathrm{N}$ gains reached up to $12 \mathrm{~kg} \mathrm{~N} \mathrm{ha}^{-1}$ in the (-N) treatment and $16 \mathrm{~kg} \mathrm{~N} \mathrm{ha}^{-1}$ in the control. Using mineral fertilizer plus cotton seed waste (All org) $\mathrm{N}$ gains were highest and reached up to $28 \mathrm{~g} \mathrm{~kg} \mathrm{~N} \mathrm{ha}^{-1}$. With mineral $\mathrm{N}$ fertilization alone (All), $\mathrm{N}$ gains were about $18 \mathrm{~kg} \mathrm{~N} \mathrm{ha}^{-1}$. After cotton seed waste application (org) $\mathrm{N}$ gains reached about $27 \mathrm{~kg} \mathrm{~N} \mathrm{ha}^{-1}$.

In contrast, in the degraded $\mathrm{CH} 2$ soil in all treatments the $\mathrm{N}_{\text {min }}$-balance was negative. However, $\mathrm{N}_{\min }$ losses from the soil-plant system were lowest after combined mineral plus organic fertilizer application (All org) with $24 \mathrm{~kg} \mathrm{~N} \mathrm{ha}^{-1}$. The largest $\mathrm{N}_{\min }$ depletion during maize growth was calculated in the $(-\mathrm{N})$ treatment $\left(67 \mathrm{~kg} \mathrm{~N} \mathrm{ha}^{-1}\right)$ and in the control $\left(65 \mathrm{~kg} \mathrm{~N} \mathrm{ha}^{-1}\right)$ leading to the highest $\mathrm{N}$ losses in these treatments $\left(53 \mathrm{~kg} \mathrm{~N} \mathrm{ha}^{-1}\right)$.

Since $\mathrm{N}$ uptake in the fertilized plots was close to the amount of $\mathrm{N}$ applied, the positive $\mathrm{N}$ balance was signifying additional $\mathrm{N}$ gains by $\mathrm{N}$ mineralization from the soil organic $\mathrm{N}$ pool and through rainfall. According to HäRDTER (1989) N gains by rainfall in the area around Nyankpala are low reaching values of $8-9 \mathrm{~kg} \mathrm{~N} \mathrm{ha}^{-1}$ year $^{-1}$. Therefore, $\mathrm{N}$ gains higher than $10 \mathrm{~kg} \mathrm{~N} \mathrm{ha}{ }^{-1}$ might be attributed to SOM mineralization. Throughout the season $\mathrm{N}_{\text {min }}$ content in the $0-90 \mathrm{~cm}$ soil layer was much higher than the amount of $\mathrm{N}$ uptake by maize, indicating that relatively large amounts of $\mathrm{N}$ were being mineralized in the soil, contributing substantially to plant $\mathrm{N}$ supply in soil and possible losses. 
Table 29: $\quad \mathrm{N}_{\min }$-balance $\left(\mathrm{kg} \mathrm{N} \mathrm{ha}^{-1}\right)$ over a soil profile depth of $0-90 \mathrm{~cm}$ under maize in the third season as affected by fertilizer application. Locations: $\mathrm{CH} 1$ and $\mathrm{CH} 2$.

\begin{tabular}{|c|c|c|c|c|c|c|c|c|c|}
\hline \multirow[b]{2}{*}{$\begin{array}{l}\text { Treat- } \\
\text { ment }\end{array}$} & \multirow[b]{2}{*}{$\begin{array}{c}\text { Fertilizer } \\
\text { application }\end{array}$} & \multicolumn{4}{|c|}{ CH 1 (non-degraded) } & \multicolumn{4}{|c|}{$\mathrm{CH} 2$ (degraded) } \\
\hline & & $\begin{array}{c}N_{\min } \\
20.06 .95\end{array}$ & $\begin{array}{c}\mathrm{N}_{\min } \\
11.10 .95\end{array}$ & $\begin{array}{l}\text { N uptake at } \\
\text { harvest } 1995\end{array}$ & $\Delta \mathbf{N}$ & $\begin{array}{c}N_{\min } \\
20.06 .95\end{array}$ & $\begin{array}{c}\mathrm{N}_{\min } \\
11.10 .95\end{array}$ & $\begin{array}{l}N \text { uptake at } \\
\text { harvest } 1995\end{array}$ & $\Delta \mathbf{N}$ \\
\hline All & 100 & 108 & 117 & 109 & 18 a & 126 & 89 & 95 & -42 bc \\
\hline All org & 133 & 120 & 158 & 123 & 28 a & 142 & 125 & 126 & $-24 b$ \\
\hline$-\mathbf{N}$ & - & 63 & 50 & 25 & 12 a & 99 & 32 & 14 & $-53 c$ \\
\hline org & 33 & 78 & 86 & 52 & 27 a & 110 & 59 & 43 & -41 bc \\
\hline control & - & 62 & 52 & 26 & $16 \mathrm{a}$ & 97 & 32 & 12 & $-53 c$ \\
\hline
\end{tabular}

Means followed by the same letter are not significantly different $(p<0.05)$ after 2-way ANOVA across sites.

The $\mathrm{N}_{\text {min }}$-balance data demonstrate the difference in $\mathrm{N}$ supply and $\mathrm{N}$ exploitation of the two sites. The higher $\mathrm{NO}_{3}{ }^{-}$content in the soil profile in the early season at $\mathrm{CH} 2$ might be one reason for high $\mathrm{N}$ losses from this site. At this time maize plants are not taking up large amounts of soil mineral $\mathrm{N}$ and accumulated $\mathrm{NO}_{3}{ }^{-}$can be easily leached with to high rainfall. In the (-N) and in the control plots maize growth was very poor with consequently very low grain yield of about $0.5 \mathrm{t} \mathrm{ha}^{-1}$. As a consequence, $\mathrm{N}$ demand and $\mathrm{N}$ uptake by maize during the cropping season was also very low. Available $\mathrm{N}$ in the soil profile was not used efficiently by maize plants and was lost from the soil-plant-system.

Surface runoff, gaseous losses due to denitrification and ammonia-volatilization after urea application were not determined. RÖMKENS et al. (1973) as cited by HÄRDTER (1989) showed that $\mathrm{N}$ losses due to runoff were minimal after incorporation of applied fertilizer. Therefore, it can be assumed that $\mathrm{N}$ losses by runoff were low. Another possible pathway of $\mathrm{N}$ losses might be denitrification, especially under very moist conditions after heavy rain during the growing period. However, denitrification losses might be insignificant because the soil was only temporarily saturated with water. Volatilization losses from applied urea may be negligible because urea was incorporated into the soil. Thus, calculated $\mathrm{N}_{\min }$ losses might be mainly due to leaching of $\mathrm{NO}_{3}{ }^{-}$. Leaching was indicated by the fast decline in $\mathrm{NO}_{3}{ }^{-}$content of the topsoil, which could not be explained by plant uptake.

Since soil organic $\mathrm{N}$ was mineralized during the growth period and thus, contributed substantially to crop nutrition, $\mathrm{N}$ fertilizer rates must be adjusted to $\mathrm{N}_{\min }$-levels in soil in order to reduce $\mathrm{N}$ losses in the system. 


\subsection{Aerobic laboratory incubation}

The assessment of mineralizable soil $\mathrm{N}$ at the beginning of the growth period is essential to get a better understanding of the net mineralization of organic $\mathrm{N}$ in the soil. This should be helpful for the elaboration of practical and reliable soil tests for available $\mathrm{N}$ in the soil.

The potential contribution of SOM to mineral $\mathrm{N}$ supply of maize was examined in two aerobic laboratory incubation experiments over three months in the third experimental year. Although $\mathrm{NH}_{4}{ }^{+}$and $\mathrm{NO}_{3}{ }^{-}$production (ammonification, nitrification) are two completely different processes of different soil microorganisms, contributing to total $\mathrm{N}$ mineralization in the soil, the results for ammonification and nitrification are presented together. ANOVA was done for each site, sampling date and incubation step $(0,7,21,42,63,84$ days) separately (Figure 7). Values in the same row (days) with the same letter are not significantly different. If the F-test was not significant at the $95 \%$ level values in the same row are marked as (ns).

\subsubsection{Cumulative mineralization of $\mathbf{N}$ after 84 days of aerobic incubation}

The total amount of mineralized $\mathrm{N}$ was dominated by net nitrification in all treatments at both sites and sampling dates. Therefore, the cumulative $\mathrm{N}$ mineralization curves presented in Figure 7 were of similar shape to those obtained for nitrification alone. In June 1995, cumulative mineral $\mathrm{N}$ found after 84 incubation days was higher at the degraded $\mathrm{CH} 2$ site and tended to be lowest in the control plots.

The average values across treatments ranged from 109 to $155 \mathrm{~kg} \mathrm{~N} \mathrm{ha}^{-1}$ for $\mathrm{CH} 1$ and $\mathrm{CH} 2$, respectively. In comparison to the first sampling at maize planting, $\mathrm{N}$ mineralization was increased by $56 \%$ in treatment (All), by $33 \%$ in treatment (org) and by $77 \%$ in the control in mid August. At $\mathrm{CH} 1$, the values ranged from $161 \mathrm{~kg} \mathrm{~N}^{-1}$ (control) to $190 \mathrm{~kg} \mathrm{~N} \mathrm{ha}^{-1}$ (All). In contrast, at CH 2 net mineralization remained nearly unchanged or increased only slightly by $2 \%$ in treatment (All) from the first to the second sampling date.

The values obtained for cumulative mineral $\mathrm{N}$ seem to be rather high. Thus, $\mathrm{N}$ mineralization in the laboratory under stable conditions might be higher than under field conditions with variations in rainfall and temperature. WELLER, 1983 as cited by MENGEL (1996) reported that dry periods cause a drastic reduction in $\mathrm{N}$ mineralization in the field. 

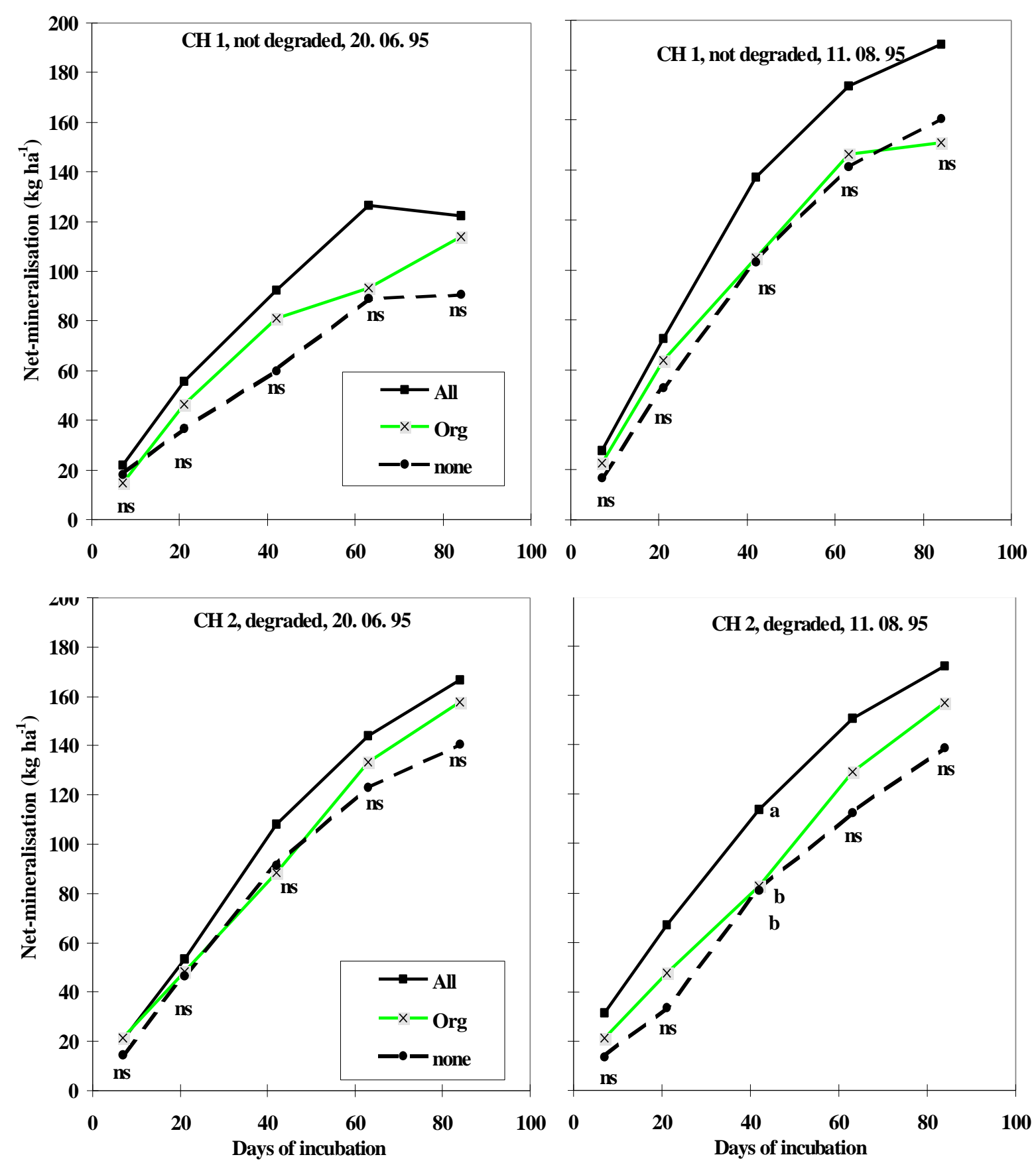

Figure 7: Cumulative net mineralization $\left(\mathrm{kg} \mathrm{N} \mathrm{ha}^{-1}\right)$ during aerobic laboratory incubation of 84 days at CH 1 and CH 2. Sampling dates: 20. 06. 1995 and 11. 08. 1995.

The absence of significant differences among the treatments in the two fields might be attributed to high coefficients of variation (CV). Apparently, three field replicates were not enough to reduce $\mathrm{CV}$ and to achieve significant treatment effects at the $95 \%$ level. 
Table 30: Cumulative net mineral $\mathrm{N}$ at the end of 84 days of aerobic incubation $\left(\mathrm{N}_{(84)}\right)$ and cumulative mineral-N as \% of total $\mathrm{N}\left(\mathrm{N}_{\text {tot }}\right)$. Locations: $\mathrm{CH} 1$ and $\mathrm{CH} 2$ before planting (20.06.95) and after fertilizer application (11.08. 95).

\begin{tabular}{|c|c|c|c|c|}
\hline Location & Sampling & Treatment & $\mathbf{N}_{(84)}\left(\mathbf{k g ~ N ~ h a}{ }^{-1}\right)$ & $\mathbf{N}_{(84)}$ in $\% \mathbf{N}_{t}$ \\
\hline \multirow[t]{4}{*}{ CH 1} & 20.06.95 & All & 122 & 5 \\
\hline & & Org & 114 & 5 \\
\hline & & none & 91 & 3 \\
\hline & & Mean & 109 & 4 \\
\hline \multirow[t]{4}{*}{ CH 2} & 20.06 .95 & All & 167 & 9 \\
\hline & & org & 158 & 9 \\
\hline & & none & 141 & 12 \\
\hline & & Mean & 155 & 10 \\
\hline \multirow[t]{4}{*}{ CH 1} & 11.08 .95 & All & 190 & 8 \\
\hline & & org & 151 & 6 \\
\hline & & none & 161 & 6 \\
\hline & & Mean & 167 & 7 \\
\hline \multirow[t]{4}{*}{ CH 2} & 11.08 .95 & All & 172 & 10 \\
\hline & & org & 157 & 9 \\
\hline & & none & 139 & 9 \\
\hline & & Mean & 156 & 9 \\
\hline
\end{tabular}

The cumulative mineral $\mathrm{N}$ in the two soils accounted for about 3 to $12 \%$ of the total $\mathrm{N}$ (Table 30), being highest at $\mathrm{CH} 2$ and lowest in the $\mathrm{CH} 1$ soil in June 1995. These observations indicate that at the beginning of the season in the degraded $\mathrm{CH} 2$ soil a higher proportion of the more stable organic $\mathrm{N}$ pool was mineralized. The relative ratio of $\mathrm{N}$ mineralized to total soil $\mathrm{N}$ was twice as high at $\mathrm{CH} 2$ with 9 to $12 \%$ as compared to the non-degraded $\mathrm{CH} 1$ site with values of 3 to $5 \%$. Consequently, the organic $\mathrm{N}$ reserves became more depleted at the degraded $\mathrm{CH} 2$ site and this depletion of the stable soil organic $\mathrm{N}$ reserves will contribute to soil degradation in the long run. 


\section{Net N-mineralization rate}

The average net $\mathrm{N}$ mineralization rate was calculated as the amount of mineral $\mathrm{N}$ divided by the span of incubation days (Figure 8). At $\mathrm{CH} 1$, in the fertilized treatments net mineralization rates were highest and decreased with incubation time. In the control a rapid decreasing phase during the first 20 incubation days was followed by a slow-steady phase demonstrating that without fertilizer input easily-degradable substrates might be exhausted after a relatively short time.
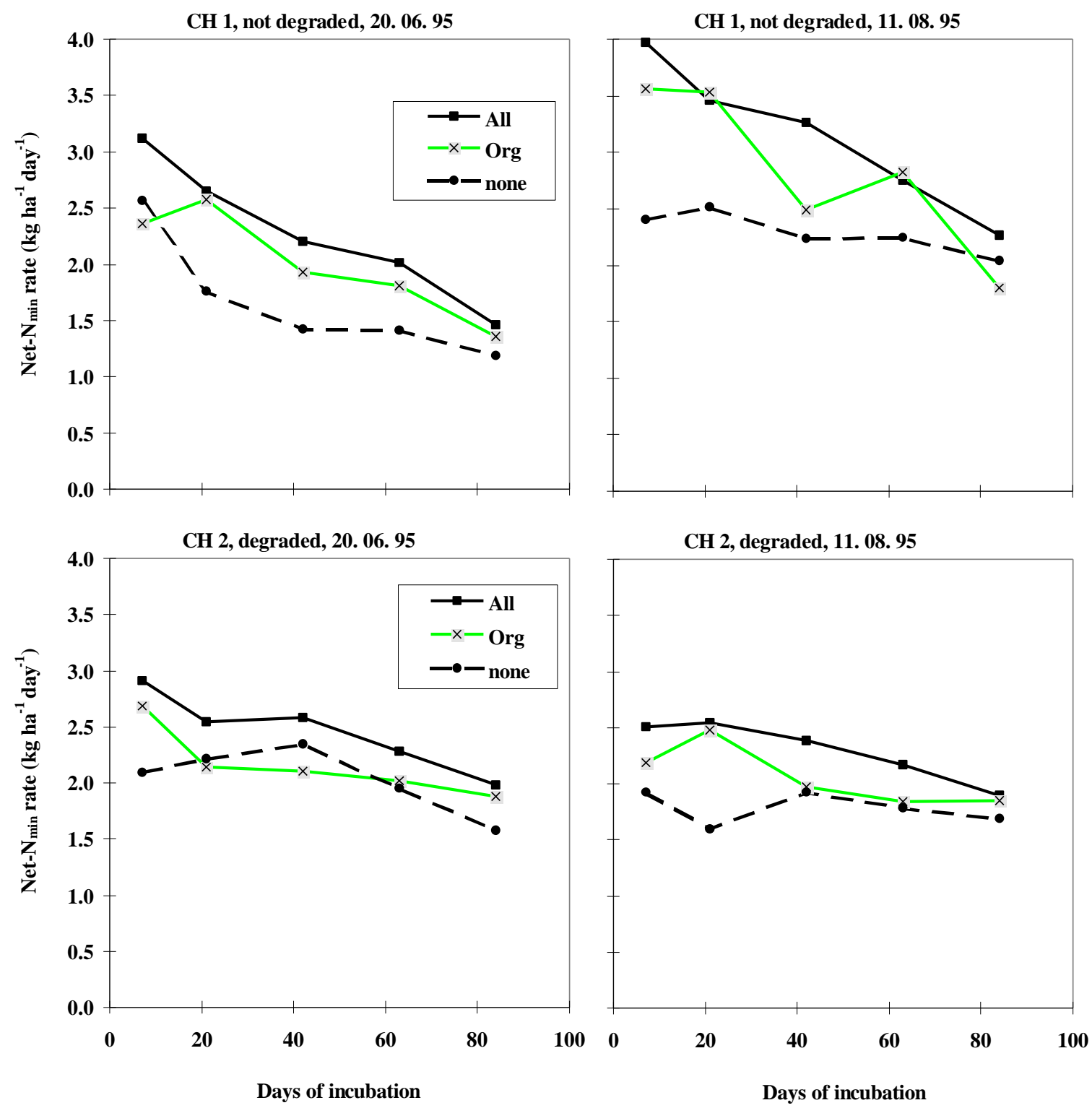

Figure 8: Mean net mineralization rate $\left(\mathrm{kg} \mathrm{N} \mathrm{ha}^{-1} \mathrm{day}^{-1}\right)$ during aerobic incubation of 84 days. Locations: $\mathrm{CH} 1$ and $\mathrm{CH}$ 2. Sampling dates: 20. 06. 95 and 11. 08. 95. 
At the second sampling date in mid August 1995, N mineralization rate in the fertilized plots showed a similar pattern as in June 1995, but at a higher level. In the control plots, $\mathrm{N}$ mineralization rate fluctuated only slightly indicating that it was close to a steady state in the middle of the season.

At $\mathrm{CH} 2$ at the first sampling date, in the fertilized treatments the rapid decreasing phase was lasting only 20 days and then changed to a slow-steady phase. The net $\mathrm{N}$ mineralization rate at the second sampling date remained lower in the fertilized plots and was corresponding with the slow-steady decreasing phase. This might be interpreted as another indication for mineralization of more recalcitrant compounds and thus degrading the soils' stable organic $\mathrm{N}$ reserves. Here, the control plots fluctuated slightly on a low level and did not differ between sampling dates. In general, $\mathrm{N}$ released during the first few weeks of incubation likely reflects the readily mineralizable or active fraction of soil organic $\mathrm{N}$, while that released later probably originates from a much larger but more stable SOM pool.

\subsubsection{Model fitting}

Soil $\mathrm{N}$ mineralization potential was investigated by aerobic incubation of 84 days. Then a first-order model or single pool model defined by the following equation $\mathrm{N}_{\mathrm{t}}=\mathrm{N}_{0}\left(1-\mathrm{e}^{-\mathrm{kt}}\right)$ was fit to the data. This model involves the concept of an $\mathrm{N}$ mineralization potential $\left(\mathrm{N}_{0}\right)$ and a constant rate of mineralization $(\mathrm{k})$.

$\mathrm{N}_{0}$ is believed to represent a pool of readily-mineralizable $\mathrm{N}$ in the soil which would reflect the impact of soil type or management. The mineralization rate constant $(\mathrm{k})$ is regarded to be more affected by temperature and moisture, which were not varied during the laboratory incubation procedure. $\mathrm{N}_{\mathrm{t}}$ is the cumulative mineral $\mathrm{N}\left(\mu \mathrm{g} \mathrm{N} \mathrm{g}{ }^{-1}\right.$ of soil) at time $\mathrm{t}$ (days). The model was fit to the observed $\mathrm{N}_{\mathrm{t}} \mathrm{vs} t$ data set using the nonlinear regression procedure. $\mathrm{N}_{0}$ and $\mathrm{k}$ were estimated for each treatment, field and sampling date (Table 31). The data can be compared for significance of differences by using the asymptotic standard errors (A. S. E.). Comparisons of observed vs predicted cumulative mineral $\mathrm{N}$ indicated that the model produced generally good predictions for all treatments throughout the incubation

Generally, complete mineral fertilizer application (All) had a positive effect on $\mathrm{N}$ mineralization potential $\left(\mathrm{N}_{0}\right)$ at both sites and sampling dates. At $\mathrm{CH} 2, \mathrm{~N}_{0}$ was always lower in the control whereas at $\mathrm{CH} 1, \mathrm{~N}_{0}$ of the control was lower only at the beginning of the season in June 1995. 
Table 31: Estimates of $\mathrm{N}$ mineralization parameters using the first-order model (single pool model) based on 84 days of aerobic laboratory incubation ${ }^{+}$.

\begin{tabular}{|c|c|c|c|c|c|c|}
\hline Location & Sampling & Treatment & Parameter & Estimate & A. S. E & Goodness of fit $\left(r^{2}\right)$ \\
\hline \multirow[t]{3}{*}{ CH 1} & 20.06 .95 & All & $\begin{array}{c}\mathbf{N}_{\mathbf{0}} \\
\mathbf{k}\end{array}$ & $\begin{array}{c}36 \\
0.024\end{array}$ & $\begin{array}{c}0.9 \\
0.001\end{array}$ & $0.97 * * *$ \\
\hline & & org & $\begin{array}{c}\mathrm{N}_{0} \\
\mathbf{k}\end{array}$ & $\begin{array}{c}36 \\
0.024\end{array}$ & $\begin{array}{c}2.3 \\
0.002\end{array}$ & $0.98 * * *$ \\
\hline & & none & $\begin{array}{c}\mathbf{N}_{0} \\
\mathbf{k}\end{array}$ & $\begin{array}{c}25 \\
0.024\end{array}$ & $\begin{array}{c}0.7 \\
0.002\end{array}$ & $0.97 * * *$ \\
\hline \multirow[t]{3}{*}{ CH 2} & 20.06. 95 & All & $\begin{array}{c}\mathbf{N}_{0} \\
\mathbf{k}\end{array}$ & $\begin{array}{c}44 \\
0.022\end{array}$ & $\begin{array}{c}0.7 \\
0.002\end{array}$ & $0.97 * * *$ \\
\hline & & org & $\begin{array}{c}\mathbf{N}_{0} \\
\mathbf{k}\end{array}$ & $\begin{array}{c}41 \\
0.022\end{array}$ & $\begin{array}{c}0.8 \\
0.001\end{array}$ & $0.97 * * *$ \\
\hline & & none & $\begin{array}{c}\mathbf{N}_{0} \\
\mathbf{k}\end{array}$ & $\begin{array}{c}36 \\
0.022\end{array}$ & $\begin{array}{c}0.7 \\
0.001\end{array}$ & $0.97 * * *$ \\
\hline \multirow[t]{3}{*}{ CH 1} & 11.08 .95 & All & $\begin{array}{c}\mathbf{N}_{0} \\
\mathbf{k}\end{array}$ & $\begin{array}{c}55 \\
0.022\end{array}$ & $\begin{array}{c}0.8 \\
0.001\end{array}$ & $0.99 * * *$ \\
\hline & & org & $\begin{array}{c}\mathbf{N}_{0} \\
\mathbf{k}\end{array}$ & $\begin{array}{c}44 \\
0.022\end{array}$ & $\begin{array}{c}0.8 \\
0.001\end{array}$ & $0.99 * * *$ \\
\hline & & none & $\begin{array}{c}\mathbf{N}_{0} \\
\mathbf{k}\end{array}$ & $\begin{array}{c}44 \\
0.021\end{array}$ & $\begin{array}{c}0.8 \\
0.001\end{array}$ & $0.97 * * *$ \\
\hline \multirow[t]{3}{*}{ CH 2} & 11.08 .95 & All & $\begin{array}{c}\mathbf{N}_{0} \\
\mathbf{k}\end{array}$ & $\begin{array}{c}50 \\
0.021\end{array}$ & $\begin{array}{c}0.8 \\
0.001\end{array}$ & $0.99 * * *$ \\
\hline & & org & $\begin{array}{c}\mathbf{N}_{0} \\
\mathbf{k}\end{array}$ & $\begin{array}{c}40 \\
0.021\end{array}$ & $\begin{array}{c}0.8 \\
0.001\end{array}$ & $0.94 * * *$ \\
\hline & & none & $\begin{array}{c}\mathbf{N}_{0} \\
\mathbf{k}\end{array}$ & $\begin{array}{c}35 \\
0.021\end{array}$ & $\begin{array}{c}0.7 \\
0.001\end{array}$ & $0.93 * * *$ \\
\hline
\end{tabular}

${ }^{+}$Units are $\mu \mathrm{g} \mathrm{N} \mathrm{g}^{-1}$ soil for $\mathrm{N}_{0}$ and day ${ }^{-1}$ for the mineralization rate constant $(\mathrm{k}) . * * * p \leq 0.001$

The data can be compared for significance of differences by using the asymptotic standard error (A. S. E.). 


\subsubsection{The use of $\mathrm{N}_{0}$ as a measure of potential $\mathrm{N}$ mineralization in the study soils}

To get an idea about the amount of potential $\mathrm{N}$ mineralization and $\mathrm{N}$ supply in the study soils and to make the data comparable to $\mathrm{N}$ uptake, values of $\mathrm{N}_{0}$ were transformed from $\mu \mathrm{g}$ $\mathrm{N} \mathrm{g}^{-1}$ soil into $\mathrm{kg} \mathrm{N} \mathrm{ha}^{-1}$. Average $\mathrm{N}_{0}$ was $136 \mathrm{~kg} \mathrm{~N}^{-1}$ at $\mathrm{CH} 1$ being about $19 \%$ lower than in the degraded CH 2 field with $167 \mathrm{~kg} \mathrm{~N} \mathrm{ha}^{-1}$ in June 1995 (Figure 9). In mid August, $\mathrm{N}_{0}$ was higher by $20 \%$ at $\mathrm{CH} 1\left(208 \mathrm{~kg} \mathrm{~N} \mathrm{ha}^{-1}\right)$ than in the $\mathrm{CH} 2$ field with $173 \mathrm{~kg} \mathrm{~N} \mathrm{ha}^{-1}$. Potential of $\mathrm{N}$ mineralization at the beginning of the season is a result of decomposing soluble organic $\mathrm{N}$, maize crop residues from the preceding season and preseason weed biomass regrowth. Crop residues probably no longer contributed to $\mathrm{N}$ mineralization in August and differences between treatments can be clearly attributed to the fertilizer input.

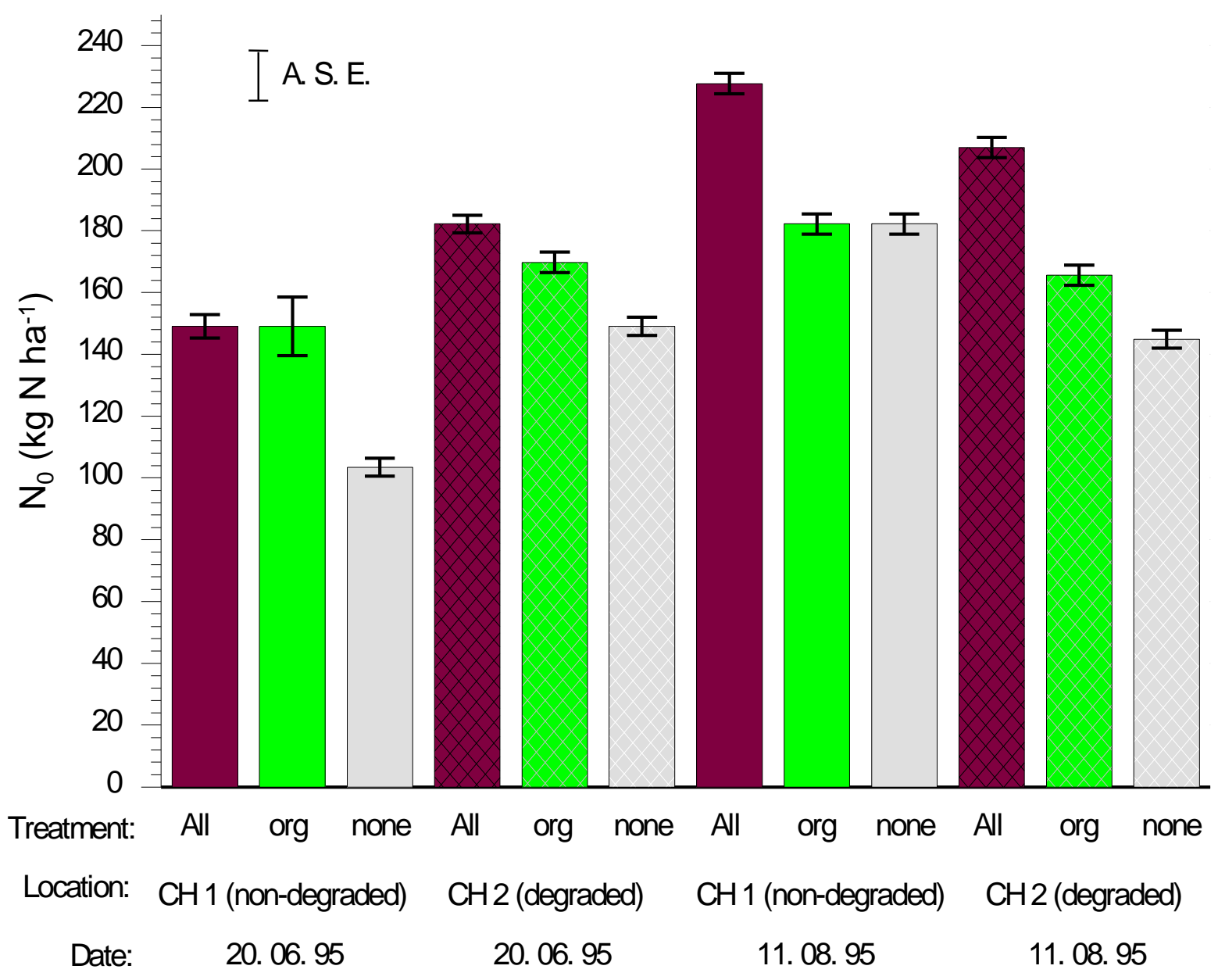

Figure 9: Estimates of $\mathrm{N}$ mineralization potential $\left(\mathrm{kg} \mathrm{N} \mathrm{ha}^{-1}\right)$ in the top soil $(0-30 \mathrm{~cm})$ using the first-order model based on 84 days aerobic incubation as affected by fertilizer input at $\mathrm{CH} 1$ and $\mathrm{CH}$ 2. (A.S.E. = asymptotic standard error). 
The results further indicate that in the non-degraded $\mathrm{CH} 1$ soil, $\mathrm{N}$ mineralization was stimulated by both mineral and organic fertilizer application, whereas in the degraded $\mathrm{CH} 2$ soil this was only observed after mineral fertilizer use. The higher $\mathrm{N}_{0}$ values at $\mathrm{CH} 2$ in June indicate that apart from residual effects of fertilizer application, which stimulated $\mathrm{N}$ mineralization, the size of the more labile pools had been increased as compared to $\mathrm{CH} 1$. This is clearly confirmed by the proportion of total $\mathrm{N}$ that was labile $\left(\mathrm{N}_{0} / \mathrm{N}_{\text {tot }}\right)$. It varied between $6 \%$ at the beginning of the season in June and $9 \%$ in mid August at $\mathrm{CH} 1$. At the degraded CH 2 site $\mathrm{N}_{0} / \mathrm{N}_{\text {tot }}$ varied between $11 \%$ in June and $10 \%$ in the middle of the season. The $\mathrm{N}_{0} / \mathrm{N}_{\text {tot }}$ ratio confirms that the size of the labile pool had been increased in the degraded field due to decomposition of the stable organic $\mathrm{N}$ pool.

In forest soils in Spain $\mathrm{N}_{0} / \mathrm{N}_{\text {tot }}$ varied between 0.3 and $3 \%$ of total $\mathrm{N}$ (GONZALEZ-PRIETO et al., 1996) and in soils in Kenya it was about $4 \%$ (BARRIOS et al., 1996). According to MENGEL (1996) in long-term experiments in Germany it was shown that about $90 \%$ of the organic $\mathrm{N}$ was very resistant to mineralization and only about 5 to $6 \%$ of the total soil $\mathrm{N}$ was accessible to mineralization during a long-lasting incubation according to the technique of STANFORD and SMITH (1972) as cited by CAMPBELL et al. (1981). CONNELL et al. (1995) reported values of only 0.2 to $3 \%$ as the percentage of total $\mathrm{N}$ mineralized in forest soils in Australia, while CAMPBELL et al. (1981) found a variation between $8 \%$ and $21 \%$ in five Queensland soils. This range was similar to that found by STANDFORD and SMITH (1972) and OYANEDEL and RoDRIGUEZ (1977) as cited by CAMPBELL et al. (1981). It was also similar to that found in some Australien soils (GREENLAND and FORD, 1964 as cited by CAMPBell et al., 1981). BenedeTti and Sebastiani (1996) sampled 30 soils $(0-40 \mathrm{~cm})$ in central and northern Italy showing that $\mathrm{N}_{0} / \mathrm{N}_{\text {tot }}$ in more than $65 \%$ of the samples ranged between 7 to $13 \%$. They concluded that this ratio might be suitable as a rapid index of potentially mineralizable $\mathrm{N}$ obtained by measuring only the total $\mathrm{N}$ content.

\section{Relationships between preseason $\mathbf{N}$ mineralization potential $\left(\mathbf{N}_{0}\right)$ and soil properties}

Linear correlations of preseason $\mathrm{N}_{0}$ versus chemical soil properties $(0-30 \mathrm{~cm})$ were calculated for each site at the beginning of the third cropping season (Table 32). At the non-degraded site $\mathrm{CH} 1$, preseason $\mathrm{N}_{0}$ was moderately negative correlated with organic $\mathrm{C}$, total $\mathrm{N}, \mathrm{CEC}$, exchangeable $\mathrm{K}$ and $\mathrm{B}$-glucosidase activity. A relatively strong negative correlation was found between potentially mineralizable $\mathrm{N}$ and protease activity. 
Table 32: Correlation coefficients $(\mathrm{r})$ of preseason $\mathrm{N}$ mineralization potential $\left(\mathrm{N}_{0}\right)$ versus selected soil parameters (depth $0-30 \mathrm{~cm}$ ). Sampling date: 20. 06. 1995. Locations: $\mathrm{CH} 1(\mathrm{n}=9), \mathrm{CH} 2(\mathrm{n}=9)$.

\begin{tabular}{lcc}
\hline Soil parameter & CH 1 (non-degraded) & CH 2 (degraded) \\
\hline Organic carbon $\left(\mathrm{C}_{\text {org }}\right)$ & $-0.55^{+}$ & $0.20 \mathrm{~ns}$ \\
Total N $\left(\mathrm{N}_{\text {tot }}\right)$ & $-0.60^{+}$ & $-0.36 \mathrm{~ns}$ \\
C/N ratio & $0.44 \mathrm{~ns}$ & $-0.24 \mathrm{~ns}$ \\
pH & $0.27 \mathrm{~ns}$ & $0.62^{+}$ \\
available P & $-0.18 \mathrm{~ns}$ & $-0.40 \mathrm{~ns}$ \\
organic P & $-0.29 \mathrm{~ns}$ & $0.84 \mathrm{~ns}$ \\
CEC & $-0.64^{+}$ & -0.26 \\
K & $-0.60^{+}$ & $0.22 \mathrm{~ns}$ \\
exchangeable Zn & $-0.42 \mathrm{~ns}$ & $-0.48 \mathrm{~ns}$ \\
C & $-0.29 \mathrm{~ns}$ & $-0.35 \mathrm{~ns}$ \\
Acid phosphatase activity & $-0.25 \mathrm{~ns}$ & $-0.20 \mathrm{~ns}$ \\
Alkaline phosphatase activity & $-0.11 \mathrm{~ns}$ & $-0.07 \mathrm{~ns}$ \\
B-Glucosidase activity & $-0.68^{*}$ & $-0.33 \mathrm{~ns}$ \\
Protease activity & $-0.73^{*}$ & $-0.23 \mathrm{~ns}$ \\
\hline
\end{tabular}

Units are $\mathrm{kg} \mathrm{N} \mathrm{ha}^{-1}$ for the $\mathrm{N}$ pool parameters $\left(\mathrm{N}_{0}\right) .{ }^{+} \geq 0.05 \leq 0.1 \mathrm{~ns}=$ not significant at the $5 \%$ level

At the degraded site $\mathrm{CH}$ 2, apart from soil $\mathrm{pH}$ and organic $\mathrm{P}$, the observed soil chemical parameters were not strongly correlated with preseason $\mathrm{N}_{0}$. Generally, soil microbial parameters were inversely correlated with $\mathrm{N}_{0}$. With the exception of $B$-glucosidase and protease activity at $\mathrm{CH} 1$, the relationships were weak and not significant.

GROOT and HoubA (1995) found only poor and no significant correlations between rates of $\mathrm{N}$ mineralization and SOM and soil $\mathrm{N}$ content. This is in line with observations presented by BENEDETTI and SEBASTIANI (1996) from 30 soils $(0-40 \mathrm{~cm})$ in central and northern Italy reporting that the results of $\mathrm{N}$ mineralization were independent of the SOM content of the soils. The results are partly in accord with MENGEL (1996), who reported similar relationships between potential $\mathrm{N}$ mineralization and soil organic $\mathrm{C}\left(\mathrm{r}=-0.29^{*}\right)$ and total $\mathrm{N}\left(\mathrm{r}=-0.37^{*}\right)$. He also reported a negative relationship with soil $\mathrm{C} / \mathrm{N}$ ratio $\left(\mathrm{r}=-0.68^{* *}\right)$ and a positive correlation with soil $\mathrm{pH}\left(\mathrm{r}=0.73^{* *}\right)$. ConNell et al. (1995) reported poor correlations between soil properties and $\mathrm{N}$ mineralization for a range of Australien forest soils. 
The relationships with potential $\mathrm{N}$ mineralization revealed positive trends with total organic $\mathrm{C}\left(\mathrm{r}=0.45^{* * *}\right)$ and total $\mathrm{N}\left(\mathrm{r}=0.49^{* * *}\right)$. CAMPBELL et al. (1981) also found a directly proportional relationship of $\mathrm{N}_{0}$ to total organic $\mathrm{C}$ in some central Queensland soils.

From the negative correlation coefficients it can be assumed that at the beginning of the third experimental year organically bound nutrients such as C, N, P and CEC but, also exchangeable $\mathrm{Zn}$ are controlling factors for $\mathrm{N}_{0}$. The relatively high correlations with microbial parameters indicate that $\mathrm{N}$ mineralization is connected to other soil microbial processes. The results further indicate that available $\mathrm{P}$, exchangeable cations and $\mathrm{Zn}$ may affect the growth of microorganisms and as such affect the mineralizable $\mathrm{N}$ pool. In these soils, available $\mathrm{P}$ content, CEC, exchangeable $\mathrm{Zn}$ and microbial $\mathrm{C}$ content was very low.

\section{Relationships between preseason $\mathrm{N}$ mineralization potential $\left(\mathrm{N}_{0}\right)$ and maize yields}

No significant relationships could be found between maize grain yields and maize $\mathrm{N}$ uptake and the estimated $\mathrm{N}$ mineralization parameters $\mathrm{N}_{0}$ and $\mathrm{k}$ from samples taken in June and August, respectively, at both locations. The lack of significant correlations of $\mathrm{N}_{0}$ and $\mathrm{k}$ with maize yields and nutrient uptake is showing the limitation of the models based on aerobic incubation technique in interpreting the results and moreover in predicting maize yields and $\mathrm{N}$ uptake when other factors may control yields. In the literature, $\mathrm{N}$ mineralization parameters rarely correlate with yield parameters or $\mathrm{N}$ uptake. Yields and $\mathrm{N}$ uptake are directly dependent on $\mathrm{N}$ supply by mineralization and/or fertilizer inputs if other factors are non-limiting. MOROKO et al. (1998) confirmed this observation in field experiments carried out in Kenya. In contrast, BARRIOS et al. (1998) reported moderate positive correlations of $\mathrm{r}=0.48$ and $\mathrm{r}=0.58$ for aerobic $\mathrm{N}$ mineralization with maize grain yield in two identical experiments in Zambia.

In June 1995 , preseason $\mathrm{N}_{\min }$ in the top soil $(0-30 \mathrm{~cm})$ was highly correlated to maize grain yield at $\mathrm{CH} 1\left(\mathrm{r}=0.85\right.$, model $\left.\mathrm{r}^{2}=0.73^{*}\right)$ and moderately correlated at $\mathrm{CH} 2$ $\left(\mathrm{r}=0.61\right.$, model $\left.\mathrm{r}^{2}=0.38^{* * *}\right)$. Inorganic $\mathrm{N}$ represents readily available soil $\mathrm{N}$, whereas $\mathrm{N}_{0}$ is related to the $\mathrm{N}$ supply from organic $\mathrm{N}$ during the maize growing season. A multiple regression model with maize grain yield $\left(\mathrm{t} \mathrm{ha}^{-1}\right)$ as a function of $\mathrm{N}_{0}\left(\mathrm{~kg} \mathrm{~N} \mathrm{ha}^{-1}\right)$ and inorganic $\mathrm{N}\left(\mathrm{kg} \mathrm{N} \mathrm{ha}^{-1}\right)$ was calculated for both sites:

$\mathrm{CH} 1$ : grain yield $=3.4+\left(-0.029 \times \mathrm{N}_{0}\right)+0.056 \times \mathrm{N}_{\min }\left(\right.$ multiple $\left.\mathrm{r}=0.93, \mathrm{r}^{2}=0.86^{* *}\right)$,

$\mathrm{CH} 2$ : grain yield $=0.68+\left(-0.051 \times \mathrm{N}_{0}\right)+0.148 \times \mathrm{N}_{\min }\left(\right.$ multiple $\left.\mathrm{r}=0.62, \mathrm{r}^{2}=0.38 \mathrm{~ns}\right)$. 
Predictability of maize grain yield increased by inclusion of $\mathrm{N}_{\min }$ with $\mathrm{N}_{0}$ in a multiple regression model only at the non-degraded $\mathrm{CH} 1$ site from 0.73 to $0.86 \%$ but not at the degraded $\mathrm{CH} 2$ site, where other factors posed yield limitations.

The increase in predictability from inclusion of $\mathrm{N}_{0}$ with $\mathrm{N}_{\min }$ in a multiple regression model was not consistent and, moreover, was too small to merit use of aerobic $\mathrm{N}$ mineralization, which is a time-consuming laboratory method. Therefore, when a fast index is needed, preseason soil $\mathrm{NO}_{3}{ }^{-}$or $\mathrm{N}_{\text {min }}$, which are relatively rapid and simple indices that relate to maize yields, are considered as appropriate soil tests in the study soils. However, with increasing precision due to increasing number of field replicates, preseason $\mathrm{N}_{0}$ seems to be a promising measure for modeling $\mathrm{N}$ mineralization potential and by including $\mathrm{N}_{\min }$ in a multiple regression model might be a good predicator for maize yields in $\mathrm{N}$ limited soils. 


\subsection{Anaerobic laboratory incubation}

This method is indicating potentially mineralizable $\mathrm{N}$ (pot- $\mathrm{N}_{\min }$ ) in the soil. It is based on $\mathrm{NH}_{4}{ }^{+}-\mathrm{N}$ released during short-term incubation of seven days under waterlogged conditions and has been suggested as a biological index of N availability (KEENEY, 1982).

Potentially mineralizable $\mathrm{N}$ varied among locations, soil depths, sampling time and treatments (Figure 10). On average, pot- $\mathrm{N}_{\text {min }}$ ranged between $14 \mathrm{~kg} \mathrm{~N} \mathrm{ha}^{-1}$ (20.06. 1995) and $16 \mathrm{~kg} \mathrm{~N} \mathrm{ha}^{-1}$ (11.08. 95) at $\mathrm{CH} 1$ and between $14 \mathrm{~kg} \mathrm{~N} \mathrm{ha}^{-1}$ (20.06. 95) and $13 \mathrm{~kg} \mathrm{~N} \mathrm{ha}^{-1}(11.08 .95)$ at $\mathrm{CH} 2$ in the top layer $(0-30 \mathrm{~cm})$ (Annex, Table 64).

In the fertilized plots at $\mathrm{CH} 1$, pot- $\mathrm{N}_{\min }$ increased from June to August, confirming the findings in the previous section, where $\mathrm{N}$ mineralization potential (after aerobic incubation) is higher after fertilizer application. At the degraded $\mathrm{CH} 2$ site, this effect was only visible in the treatment with high input of combined mineral plus organic (All org) fertilizer application.

Potentially mineralizable $\mathrm{N}$ was highest after mineral fertilizer plus cotton seed waste application (All org) followed by complete mineral (All) and organic (org) fertilizer application in both fields and sampling dates throughout the profile. In the $(-\mathrm{N})$ treatment and the control pot- $\mathrm{N}_{\min }$ was significantly lower.

In soil samples from the deeper soil layers $(30-60 \mathrm{~cm})$, relatively high amounts of $\mathrm{NH}_{4}{ }^{+}-\mathrm{N}$ were released in both fields (Annex, Table 64). At $\mathrm{CH} 1$, some $\mathrm{NH}_{4}{ }^{+}-\mathrm{N}$ was released even in the $60-90 \mathrm{~cm}$ soil horizon. At $\mathrm{CH} 2$ values became partly negative. Fertilizer application increased preseason pot- $\mathrm{N}_{\min }$ in the $30-60 \mathrm{~cm}$ layer at both sites, whereas in the 60 - $90 \mathrm{~cm}$ layer fertilizer effects were only visible at $\mathrm{CH} 1$.

Differences in preseason pot- $\mathrm{N}_{\text {min }}$ in June 1995 can be attributed to residual fertilizer effects of the previous years. Fertilizer inputs resulted in higher stover yields and nutrient uptake (Table 48) but also in improved regrowth of fallow vegetation and thus higher amounts of crop residues at the beginning of the third season (Annex, Table 50). The relatively high pot- $\mathrm{N}_{\min }$ in deeper soil layers suggests that in the previously fertilized plots considerable amounts of root residues were available. These organic substrates in the soil profile might have been mineralized at the beginning of the rainy season. 

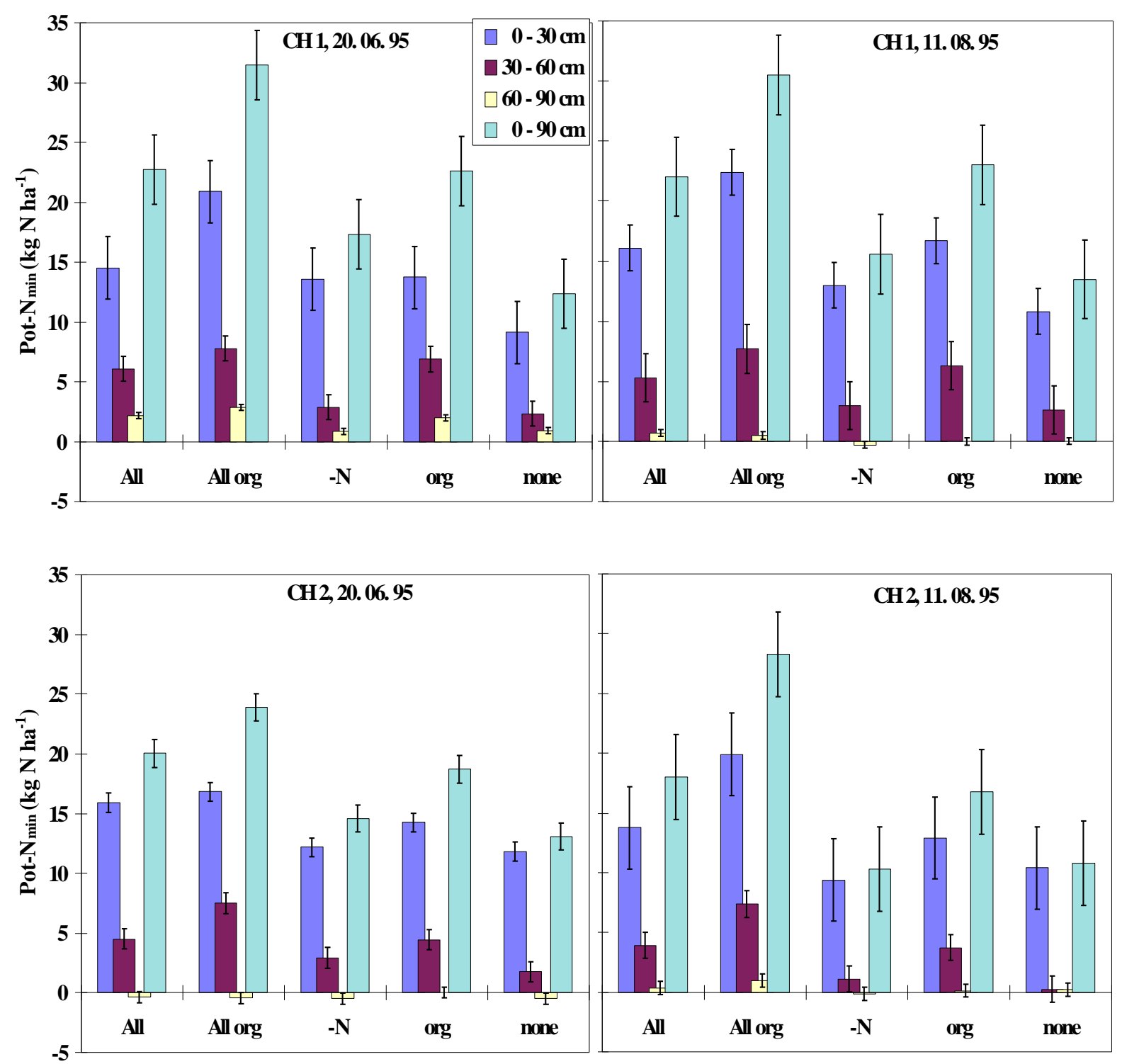

Figure 10: Estimates of potential $\mathrm{N}$ mineralization (pot- $\mathrm{N}_{\min }$ ) based on 7 days of anaerobic incubation in soil layers of $0-30 \mathrm{~cm}, 30-60 \mathrm{~cm}, 60-90 \mathrm{~cm}$. Locations: $\mathrm{CH} 1$ (not degraded), CH 2 (degraded). Sampling Dates: 20. 06. 95 and 11. 08. 95. (Error bares represent LSD values at the $5 \%$ level of data from each sampling date and from each soil layer separately).

\section{Relationships between potential $\mathbf{N}$ mineralization (pot- $\mathbf{N}_{\min }$ ) and soil properties}

Pair-wise linear correlations between pot- $\mathrm{N}_{\min }$ versus soil properties were calculated for the first sampling date (20.06. 95) at both sites in the top soil $(0-30 \mathrm{~cm})$. Preseason pot- $\mathrm{N}_{\min }$ was only weakly correlated with soil organic $\mathrm{C}$ and total $\mathrm{N}$ content at the non-degraded $\mathrm{CH} 1$ site and did not show a significant relationship at the degraded CH 2 site (Table 33). 
Table 33: Correlation coefficients of pot- $\mathrm{N}_{\min }\left(\mathrm{kg} \mathrm{N}^{-1}\right)$ versus selected soil parameter of the top soil (0 - $30 \mathrm{~cm})$. Sampling Date: 20. 06. 95. Location: CH 1, CH 2.

\begin{tabular}{|c|c|c|}
\hline Soil parameter & $\begin{array}{c}\text { Correlation coefficients (r) } \\
\text { pot- } \mathrm{N}_{\min } \text { CH } 1(\mathbf{n}=25)\end{array}$ & pot- $\mathrm{N}_{\min } \mathrm{CH} 2(\mathrm{n}=25)$ \\
\hline Total $\mathbf{N}\left(\mathbf{N}_{\text {tot }}\right)$ & $0.40 *$ & ns \\
\hline Organic carbon $\left(\mathrm{C}_{\text {org }}\right)$ & $0.35^{+}$ & ns \\
\hline CEC & $0.47 *$ & $0.47 *$ \\
\hline exchangeable K & $0.57 * * *$ & $0.41 *$ \\
\hline exchangeable Mg & $0.45^{*}$ & $0.49 *$ \\
\hline exchangeable Zn & $0.31^{+}$ & $0.56 * *$ \\
\hline extractable sulfate-S & ns & $0.48 *$ \\
\hline $\mathbf{N}_{\min }$ & $0.53 * *$ & $0.54 * *$ \\
\hline $\mathbf{C}_{\text {mic }}$ & $0.39 *$ & $0.48^{*}$ \\
\hline Acid phosphatase activity & $0.16 \mathrm{~ns}$ & $\mathbf{0 . 7 0} * * *$ \\
\hline Alkaline phosphatase activity & $0.24 \mathrm{~ns}$ & ns \\
\hline B-Glucosidase activitiy & $0.51 * *$ & $0.44 *$ \\
\hline Protease activity & $0.37^{+}$ & $0.40 *$ \\
\hline
\end{tabular}

At both sites organic $\mathrm{C}$ and total $\mathrm{N}$ content was low, however, at the degraded site $\mathrm{CH} 2$ they were much lower, probably close to steady state conditions, explaining why no correlations were found at this site. At both sites, pot- $\mathrm{N}_{\min }$ was correlated with CEC, exchangeable $\mathrm{K}, \mathrm{Mg}$ and $\mathrm{Zn}$. At $\mathrm{CH} 2$, pot- $\mathrm{N}_{\min }$ was also correlated with extractable sulfate-S. Moderate correlations were found between pot- $\mathrm{N}_{\min }$ with mineral $\mathrm{N}$ and microbial C content, $\beta$-glucosidase and protease activity at both sites. There was also a relatively strong correlation between pot- $\mathrm{N}_{\min }$ and acid phosphatase activity at the degraded CH 2 site. Generally, the correlation coefficients varied appreciably from site to site.

\section{Relationships between anaerobic $\mathrm{NH}_{4}-\mathrm{N}$ production and maize yield parameters}

In contrast to $\mathrm{N}_{0}$ estimates obtained after aerobic incubation, significant relationships could be found between maize grain yield and $\mathrm{N}$ uptake in aboveground maize biomass with the preseason pot- $\mathrm{N}_{\min }$ from soil samples taken in June 1995 at both locations (Table 34). The relationships obtained at the degraded $\mathrm{CH} 2$ site were much stronger, suggesting that maize production and $\mathrm{N}$ uptake was more influenced by $\mathrm{N}$ supply due to $\mathrm{N}$ mineralization from the labile soil organic $\mathrm{N}$ pool as compared to the non-degraded $\mathrm{CH} 1$ site. 
Table 34: Regression equations for relationships of pot- $\mathrm{N}_{\min }\left(\mathrm{kg} \mathrm{N} \mathrm{ha}{ }^{-1}\right)$ versus maize grain yield $\left(\mathrm{t} \mathrm{ha}^{-1}\right)$ and aboveground total maize biomass $\mathrm{N}$ uptake $\left(\mathrm{kg} \mathrm{N} \mathrm{ha}^{-1}\right)$. Sampling Date: 20. 06. 1995. Locations: CH $1(\mathrm{n}=25)$ and $\mathrm{CH} 2(\mathrm{n}=25)$.

\begin{tabular}{|c|c|c|c|c|}
\hline Independent parameters & Dependent parameters & Function & $\mathbf{r}$ & Model $\mathbf{r}^{2}$ \\
\hline & CH 1 (non-degraded) & & & \\
\hline pot- $\mathbf{N}_{\min }(0-30 \mathrm{~cm})$ & Maize grain yield & $y=0.09+0.18$ pot $-N_{\min }$ & 0.64 & $0.41^{* * *}$ \\
\hline pot- $N_{\min }(0-90 \mathrm{~cm})$ & Maize grain yield & $y=-0.50+0.15$ pot $-N_{\min }$ & 0.76 & $0.57 * * *$ \\
\hline pot-N $N_{\min }(0-30 \mathrm{~cm})$ & Total maize $\mathrm{N}$ uptake & $y=-4.16+4.85$ pot $-N_{\min }$ & 0.62 & $0.38 * * *$ \\
\hline \multirow[t]{2}{*}{ pot- $\mathrm{N}_{\min }(0-90 \mathrm{~cm})$} & Total maize $\mathrm{N}$ uptake & $y=-19.58+3.99$ pot $-N_{\text {min }}$ & 0.73 & $0.53 * * *$ \\
\hline & $\mathrm{CH} 2$ (degraded) & & & \\
\hline pot- $\mathbf{N}_{\min }(0-30 \mathrm{~cm})$ & Maize grain yield & $y=-6.55+0.63$ pot $-N_{\min }$ & 0.83 & $0.70 * * *$ \\
\hline pot- $N_{\min }(0-90 \mathrm{~cm})$ & Maize grain yield & $y=-4.34+0.37$ pot $-N_{\min }$ & 0.89 & $0.79 * * *$ \\
\hline pot- $\mathbf{N}_{\min }(0-30 \mathrm{~cm})$ & Total maize $\mathrm{N}$ uptake & $y=-140.7+14.3$ pot $-N_{\min }$ & 0.78 & $0.61 * * *$ \\
\hline pot- $N_{\min }(0-90 \mathrm{~cm})$ & Total maize $\mathrm{N}$ uptake & $y=-92.20+8.58$ pot $-N_{\min }$ & 0.84 & $0.70 * * *$ \\
\hline
\end{tabular}

A multiple regression model with grain yield $\left(\mathrm{t} \mathrm{ha}^{-1}\right)$ as a function of pot- $\mathrm{N}_{\min }\left(\mathrm{kg} \mathrm{N} \mathrm{ha}^{-1}\right)$ and soil $\mathrm{N}_{\min }\left(\mathrm{kg} \mathrm{N} \mathrm{ha}^{-1}\right)$ was calculated for both sites in the top soil $(0-30 \mathrm{~cm})$ and across the soil profile $(0-90 \mathrm{~cm})$ :

$\mathrm{CH} 1(0-30 \mathrm{~cm}): \mathrm{y}=-3.3+\left(-0.07 \times\right.$ pot- $\left.\mathrm{N}_{\min }\right)+\left(0.06 \times \mathrm{N}_{\min }\right) \quad$ (multiple $\left.\mathrm{r}=0.88, \mathrm{r}^{2}=0.78 * * *\right)$,

CH $1(0-90 \mathrm{~cm}): \mathrm{y}=-2.2+\left(-0.06 \mathrm{x}\right.$ pot- $\left.\mathrm{N}_{\min }\right)+\left(0.04 \times \mathrm{N}_{\min }\right) \quad$ (multiple $\left.\mathrm{r}=0.93, \mathrm{r}^{2}=0.86^{* * *}\right)$,

$\mathrm{CH} 2(0-30 \mathrm{~cm}): \mathrm{y}=-8.83+\left(0.53 \times\right.$ pot- $\left.\mathrm{N}_{\min }\right)+\left(0.53 \times \mathrm{N}_{\min }\right) \quad$ (multiple $\left.\mathrm{r}=0.86, \mathrm{r}^{2}=0.73 * * *\right)$,

$\mathrm{CH} 2(0-90 \mathrm{~cm}): \mathrm{y}=-5.62+\left(0.27 \mathrm{x}\right.$ pot- $\left.\mathrm{N}_{\min }\right)+\left(0.03 \times \mathrm{N}_{\text {min }}\right) \quad\left(\right.$ multiple $\left.\mathrm{r}=0.90, \mathrm{r}^{2}=0.82 * * *\right)$.

Predictability of maize grain yield increased when the whole soil profile was considered in the calculation. The combination of $\mathrm{N}_{\min }$ and pot- $\mathrm{N}_{\min }$ in a multiple regression model provides the best predictability of maize grain yield at both sites. The predictability of maize grain yield further increased when the whole soil profile $(0-90 \mathrm{~cm})$ was considered. BARRIOS et al. (1998) and MOROKO et al. (1998) also reported positive correlations of pot- $\mathrm{N}_{\min }$ with maize grain yield at sites in Kenya and Zambia, respectively. Their results suggest that maize grain yield in $\mathrm{N}$ deficient soils is strongly related to the additive effects of preseason soil inorganic $\mathrm{N}$ and a soil fraction related to $\mathrm{N}$ mineralization. 


\subsection{Comparison between aerobic and anaerobic incubation studies}

Laboratory incubations have been used to asses the potential ability of soils to provide $\mathrm{N}$ for crop growth. Estimates from anaerobic, but not from aerobic incubation, were significantly correlated with maize yield parameters and $\mathrm{N}$ uptake in both soils. Thus, our results confirm results from BARRIOS et al (1998) and MOROKO et al. (1998) who both reported that maize grain yield was better related to anaerobic than aerobic $\mathrm{N}$ mineralization. The different $\mathrm{N}$ requirements of soil aerobes and anaerobes might account for the inconsistency and differences in the relationships of aerobic and anaerobic $\mathrm{N}$ mineralization to maize yield (BARRIOS et al., 1998). Anaerobes can have lower $\mathrm{N}$ requirements than aerobes, and net release of inorganic $\mathrm{N}$ from decomposing residues can occur at higher $\mathrm{C} / \mathrm{N}$ ratios under anaerobic conditions (PATRICK, 1982 as cited by BARRIOS et al., 1998).

The results of the anaerobic laboratory incubation varied between sites, sampling dates, soil depth and treatments suggesting that this method is sensitive enough to detect changes in $\mathrm{N}$ availability. Thus, the values can be viewed as relative indications of soil $\mathrm{N}$ availability and consequently as suitable biological indicators for soil quality. Although previous reviews have cited numerous reports of satisfactory relationships between results from this method and other indices (KEENEY, 1982; STANFORD, 1982; MEISINGER, 1984; BARRIOS et al., 1998; MоRоко et al., 1998), several studies have found poor correlations between $\mathrm{NH}_{4}-\mathrm{N}$ production under waterlogged conditions and field measurements of $\mathrm{N}$-availability (FoX and PIEKIELEK, 1984; MCCRACKEN et al., 1989; Hong et al., 1990).

BoONE (1990) suggested that the apparent differences between $\mathrm{N}$ availability measured via anaerobic incubation and field data are not contradictions but instead reflect differences in $\mathrm{N}$ pathways as measured by the two methods. Specifically, field measurements represent the net effect of $\mathrm{N}$ mineralization and $\mathrm{N}$ immobilization under aerobic conditions, while the waterlogged incubation likely measures $\mathrm{N}$ mineralization from aerobic soil organisms killed by the anaerobic test conditions. Our results presented above have clearly shown that the estimate of mineralization potential in soil extracts by the anaerobic incubation procedure was of acceptable precision in the study soils. 


\section{$6 \quad$ General Discussion and Conclusions}

The main objective of the study was to improve the understanding of nutrient cycling in agroecosystems in the savanna region of northern Ghana. In order to assess a general soil quality status of the study sites and to evaluate the potential for sustainable productivity, reliable measurements of soil quality should distinguish between contrasting sites, and at the same time, be sensitive to changes in management practices. It is suggested to include microbiological soil parameters in soil quality assessments of savanna soils.

The challenge is to identify those soil parameters that are affected most by soil and crop management. From this information it may be possible to determine which set of soil biological properties can be used as early and sensitive indices of soil degradation or of soil fertility maintenance. In chapter 5 it was demonstrated that cultivation of soils affected soil chemistry and also soil biology. The results suggested that the underlying processes at the levels of biochemistry and microbial dynamics were complex and the parameters are multicolinear (Annex, Table 54 and Table 63). They were all considered of significance for soil quality and, accordingly, each of them has to be interpreted taking into account the others. With a large number of factors involved, it is necessary to assess and describe soil quality in terms of different sets of properties. This can best be achieved by computing multivariate statistical analysis from which principal component analysis (PCA) was used to (1) use the information on multicolinearity to reduce the number of variables and (2) to detect an interpretable structure among variables.

By PCA the information from several individual soil parameters was extracted into a few principal components (PC), that played a significant role in explaining the variance in the data set. For computing PCA, a sub-set of treatments was selected including the treatments (All), (All org), (-N), (org) and the control. Criteria for treatment selection were

(1) completeness of the data set and (2) most contrasting history.

For the degraded $\mathrm{CH} 2$ site severe $\mathrm{P}$ deficiency in soil was shown by low levels of available $\mathrm{P}$ (Table 15) and by low maize yield and P uptake (Table 9 and 10). Therefore, it seems to be possible that soil microorganisms might be limited also by available P in soil. Although, $\mathrm{P}$ was identified as the second most limiting nutrient for maize production, the (-P) treatment was not included into the PCA because mineral $\mathrm{N}$ and $\mathrm{N}$ mineralization potential were not determined in these plots due to limited analytical capacity. 
A more detailed assessment of P-cycling in soil such as determination of microbial $\mathrm{P}$ content and $\mathrm{C}_{\text {mic }}-\mathrm{P}_{\text {mic }}$-ratio was beyond the scope of this thesis.

As $\mathrm{N}$ mineralization after aerobic incubation was only measured in the third season on a sub-set of three contrasting treatments and three replications, $\mathrm{N}$ mineralization potential after anaerobic incubation was included in the data sets for computing PCA.

\subsection{Identification of soil processes}

The main aims were

to directly link initial soil quality with land use;

to relate maize productivity with initial soil quality;

- to identify the most appropriate variables that determine soil quality as affected by two years of sequential maize cropping with varying fertilizer inputs;

- to relate maize grain yield to soil quality at the beginning of the third cropping season and to ascertain that soil processes affecting maize production are directly related to fertilizer management.

\subsubsection{Soil quality as affected by land use history}

Three PCs were extracted explaining about $84 \%$ of the total variance in the initial data set from June 1993 (Table 35).

The first PC accounted for $56 \%$. The highest loadings were provided by exchangeable Ca and organic C. Exchangeable Mg, K and Zn, CEC, soil enzyme activities, organic and available $\mathrm{P}$, total $\mathrm{N}, \mathrm{NH}_{4}-\mathrm{N}$, soil $\mathrm{pH}$ and $\mathrm{N}$ mineralization potential (pot- $\mathrm{N}_{\text {min }}$ ) after anaerobic incubation also contributed substantially to the first PC. From the variables loading high, it is concluded that SOM content and related nutrient dynamics play a key role in nutrient availability and soil quality in these soils. Accordingly, the first factor was named "SOM-dynamics".

The second PC explained $13 \%$ of the variance and was characterized by high loadings of $\mathrm{C}_{\text {mic }}-\mathrm{C}_{\text {org }}$-ratio and microbial biomass $\mathrm{C}$, confirming the importance of SMB as an essential component of the quality of the soils. Consequently, the second PC was named "SMB-dynamics". 
Table 35: Principal components (PC) and varimax-rotated component loadings extracted from 21 initial soil chemical and microbial parameters of the $0-30 \mathrm{~cm}$ soil layer averaged across $\mathrm{CH} 1$ and $\mathrm{CH}$ 2. Sampling date: 13. 06. 93.

\begin{tabular}{|c|c|c|c|}
\hline \multirow[t]{2}{*}{ Variables } & \multicolumn{2}{|c|}{ Principle Component } & \multirow[b]{2}{*}{3} \\
\hline & 1 & 2 & \\
\hline exchangeable $\mathrm{Ca}$ & $\underline{0.94}^{\mathrm{a}}$ & 0.09 & 0.24 \\
\hline organic C & $\underline{0.93}$ & 0.25 & 0.14 \\
\hline exchangeable $\mathrm{Mg}$ & $\underline{0.91}$ & 0.19 & 0.30 \\
\hline CEC & $\underline{0.91}$ & 0.14 & 0.15 \\
\hline exchangeable $\mathrm{K}$ & $\underline{0.87}$ & 0.31 & 0.26 \\
\hline protease activity & $\underline{0.87}$ & 0.03 & 0.36 \\
\hline exchangeable $\mathrm{Zn}$ & $\underline{0.86}$ & 0.15 & 0.06 \\
\hline B-glucosidase activity & $\underline{0.86}$ & 0.36 & 0.21 \\
\hline organic $\mathrm{P}$ & $\underline{0.86}$ & 0.15 & 0.26 \\
\hline total $\mathrm{N}$ & $\underline{0.85}$ & 0.01 & -0.14 \\
\hline alkaline phosphatase activity & $\underline{0.85}$ & 0.31 & 0.32 \\
\hline $\mathrm{NH}_{4}-\mathrm{N}$ & $\underline{0.77}$ & 0.16 & 0.55 \\
\hline available $\mathrm{P}$ & $\underline{0.76}$ & 0.01 & 0.25 \\
\hline acid phosphatase activity & $\underline{0.67}$ & 0.35 & 0.09 \\
\hline pot- $\mathrm{N}_{\min }(\mathrm{AN})^{1}$ & $\underline{-0.63}$ & -0.14 & $\underline{-0.70}$ \\
\hline $\mathrm{pH}$ & $\underline{\mathbf{0 . 6 3}}$ & -0.05 & 0.54 \\
\hline extractable sulfate-S & 0.56 & 0.55 & 0.04 \\
\hline $\mathrm{C}_{\text {mic }}-\mathrm{C}_{\text {org }}$-ratio & -0.13 & $\underline{0.93}$ & -0.12 \\
\hline microbial biomass $\mathrm{C}$ & 0.42 & $\underline{0.87}$ & -0.09 \\
\hline pot- $\mathrm{N}_{\mathrm{min}} / \mathrm{N}_{\mathrm{tot}}(\mathrm{AN})^{\mathrm{b}}$ & -0.39 & -0.01 & $\underline{-0.86}$ \\
\hline $\mathrm{NO}_{3}-\mathrm{N}$ & 0.21 & 0.34 & $\underline{-0.77}$ \\
\hline percentage of total variance explained & 56 & 13 & 15 \\
\hline
\end{tabular}

The third PC was dominated by N-related variables such as potentially mineralizable $\mathrm{N}$ (pot- $\mathrm{N}_{\min }$ ) and its percentage of total $\mathrm{N}$ (pot- $\mathrm{N}_{\min } / \mathrm{N}_{\text {tot }}$ ) and explained $15 \%$ of the variance. A relatively high loading was also found for $\mathrm{NO}_{3}-\mathrm{N}$ on the third PC. All the $\mathrm{N}$-related variables were negatively associated with the third PC. In soil, N-related processes are microbially-driven with nutrient immobilization and mineralization. Therefore, the third PC represents a biological index of soil organic $\mathrm{N}$ turnover capacity and is interpreted as "N-dynamics". 
The three PCs describe relationships between variables and classify variables as they are characterizing different soil processes and pools involved in SOM decomposition and nutrient release. Because the first PC explained $56 \%$ of the variance, soil quality was considered to be strongly related to SOM accumulation that made a substantial contribution to soils' nutrient supply (N, P), CEC and cation exchange (Ca, Mg, K, Zn). The SOM pool is characterized by slow decomposition and turnover rates of organic $\mathrm{C}, \mathrm{N}$ and $\mathrm{P}$. These biochemical processes are closely linked to soil-enzyme activities. The high loadings of enzyme activities on the first PC confirm their importance. This was in line with the high correlation coefficients among $\mathrm{C}_{\text {org }}$ content and soil enzyme activities (Annex, Table 54).

The second and third PCs represent the labile or more easily-decomposable fractions of SOM. Soil microbial biomass is generally considered as the active part of SOM and has the highest turnover rate. Soil microorganisms serve as a source and sink of soil nutrients and provide a "driving force" of nutrient availability (BLAGODATSKY and RICHTER (1998). Thus, soil microbial biomass is interpreted as an indicator of the state and change of SOM in the study soils. These results are in line with JORDAN et al. (1995), DIEKMANN (1997) and WICK et al. (1998) who all agree on the use of microbial biomass C as an indicator of soil quality because of its high sensitivity to changes in land use and management practices.

The third PC reflects the $\mathrm{N}$ availability dependent on $\mathrm{N}$-supplying potential from soil organic $\mathrm{N}$. In $\mathrm{N}$-cycling, protein degradation of organic $\mathrm{N}$ compounds by proteases is considered a major process as indicated by high loading of soil protease activity on the first PC. Nitrogen turnover rates are governed by available energy sources in soils with very low SOM content as shown by the high loading of $\beta$-glucosidase activity, which is reflecting energy supply (glucose) for soil microorganisms and the same time the high negative loading of pot- $\mathrm{N}_{\min }$ on the first PC.

\section{Principal component scores}

By computing PC scores we can estimate the actual values of individual variables or of selected plots of each site for the PCs. The PC scores clearly reflect the variability in each field but still differentiated the two fields with respect to soil degradation (Figure 11 and 12). To compare the two sites the arithmetic mean of PC scores for each of the fields was calculated. The PC scores of plots at the non-degraded site $(\mathrm{CH} \mathrm{1)}$ were scattered on a large range mainly in the upper two quadrants, whereas the scores at the degraded site $(\mathrm{CH} 2)$ clustered more homogeneously in the lower quadrants (Figure 11). 


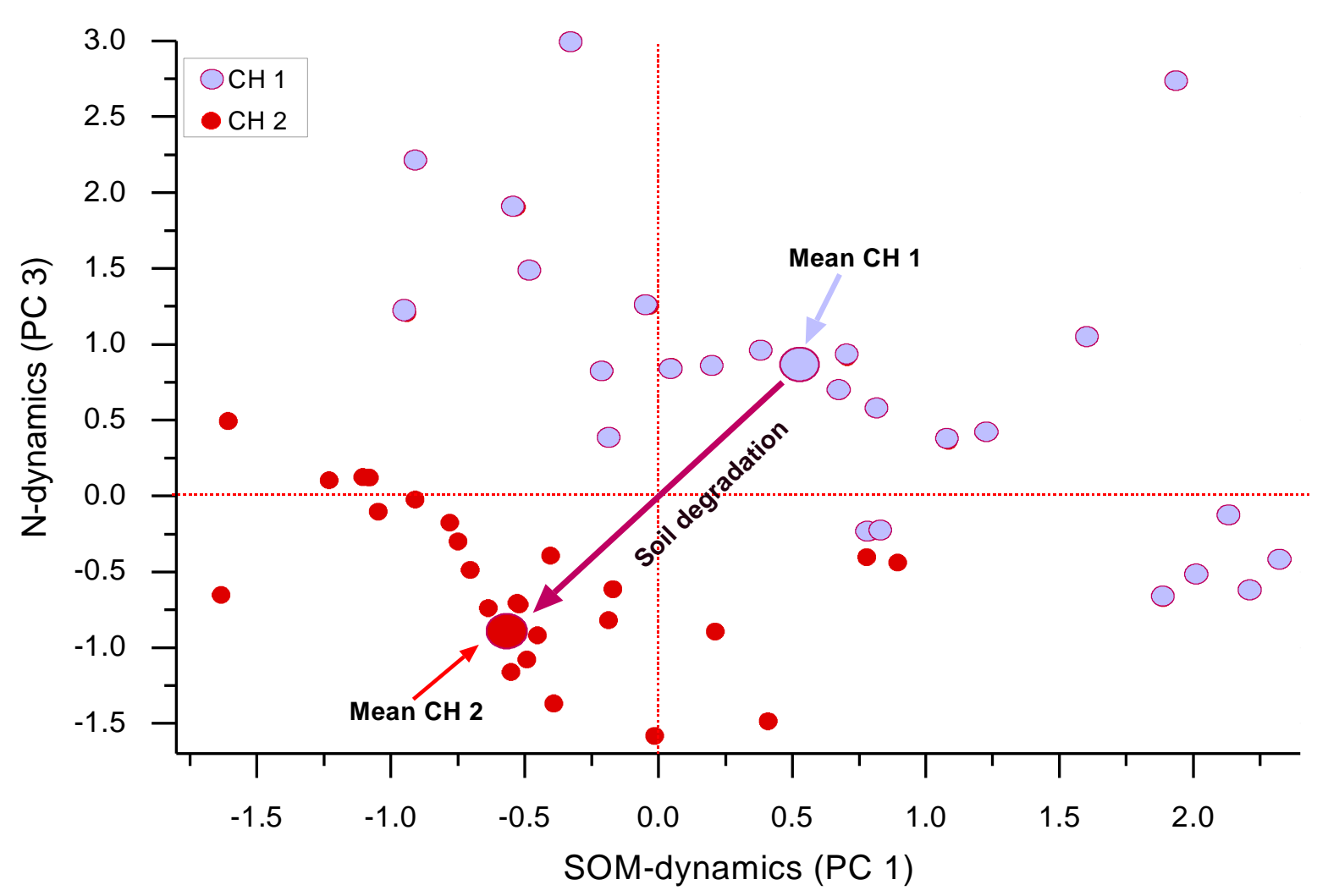

Figure 11: Component scores of experimental plots and their assignment to the first and third principal component at $\mathrm{CH} 1$ (non-degraded) and $\mathrm{CH} 2$ (degraded). Sampling date: 13.06. 1993 at a soil depth of $0-30 \mathrm{~cm}$.

The initial status of the non-degraded $\mathrm{CH} 1$ site was characterized by positive (above average) SOM- and N-dynamics scores (Figure 11). In contrast, SMB-dynamics yielded slightly negative (below average) scores at $\mathrm{CH} 1$ (Figure 12).

The degraded $\mathrm{CH} 2$ site was characterized by negative PC scores of all the three PCs. Lower SOM-, SMB- and N-dynamics contribute to overall soil degradation in this nutrient-poor soil. Therefore, soil degradation processes must be considered as a function of several chemical and biochemical properties, which are reflecting soil processes. The overall result of computing PC scores was that soil degradation at the $\mathrm{CH} 2$ site could be generally equated with a loss in SOM and with subsequent decrease in nutrient-holding capacity, CEC and availability of plant nutrients. However, SOM-related and microbialdriven nutrient cycling processes showed differential trends. Initial SMB-dynamics were only slightly lower at the degraded $\mathrm{CH} 2$ site than at the non-degraded $\mathrm{CH} 1$ site and did not differentiate clearly between the two fields. 


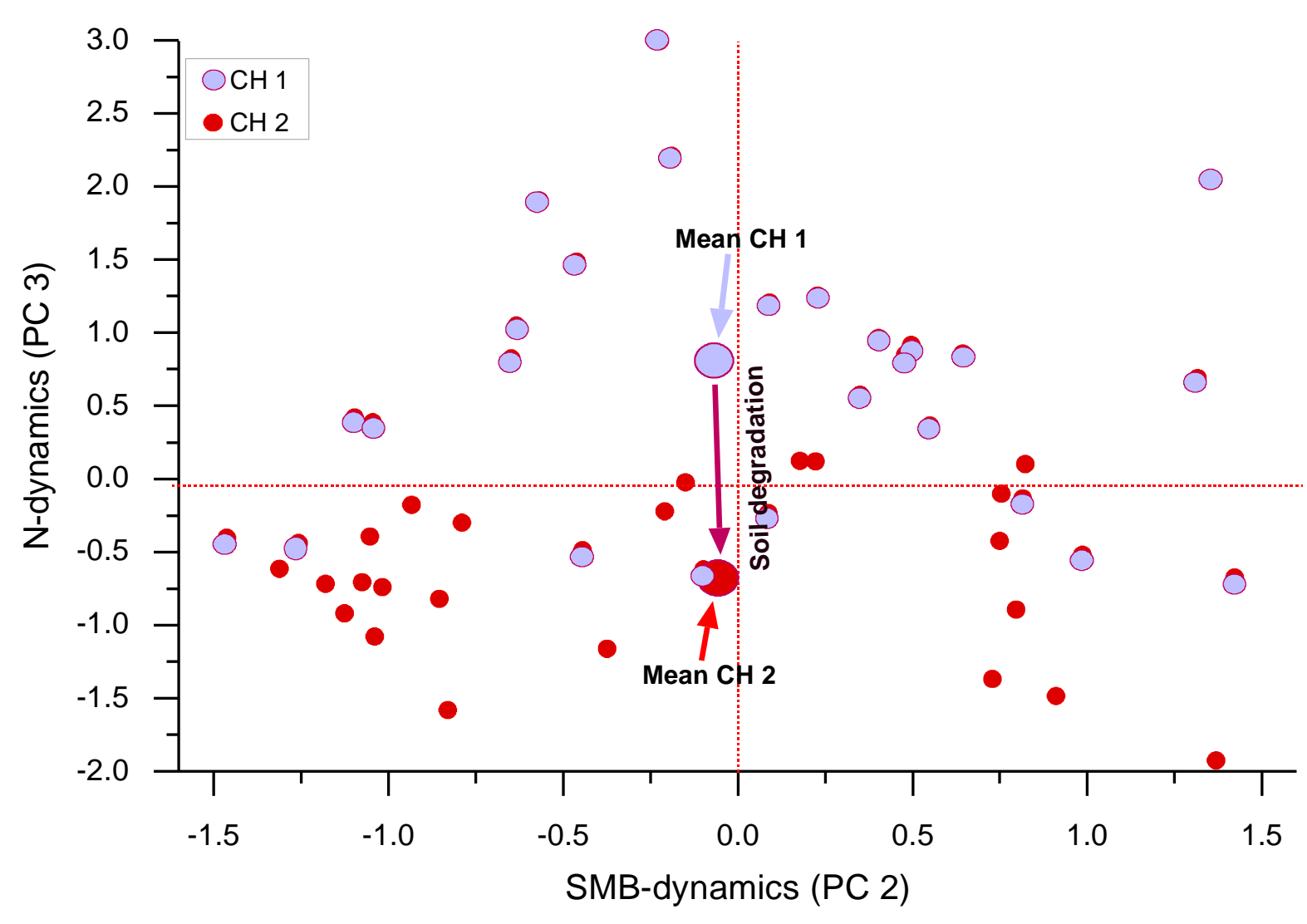

Figure 12: Component scores of experimental plots and their assignment to the second and third principal component at $\mathrm{CH} 1$ (non-degraded) and $\mathrm{CH} 2$ (degraded). Sampling date: 13. 06. 1993 at a soil depth of $0-30 \mathrm{~cm}$.

Relatively low SMB-dynamics might be attributed to N limitations on microbial growth, as was indicated by the inverse relationship with $\mathrm{N}$ mineralization parameters. On the other hand, $\mathrm{N}$ mineralization potential, which is considered as a biological index of $\mathrm{N}$ supply, differed strongly between sites, with negative scores in the degraded soil. This is an indication that soil degradation resulted in reduced microbially mediated soil processes such as $\mathrm{N}$ mineralization.

Hence, soil degradation in the study sites must be described by

(1) a decrease in SOM and soil nutrient content with

(2) subsequent reduction of several SOM-related soil functions and chemical and biochemical reactions. 


\subsubsection{Relationship between maize yield of the first season and initial soil quality}

In order to relate maize production with the inherent soil quality status of the two sites a PCA was computed on a subset consisting of the unfertilized control plots of the initial data set including maize grain yield, which was harvested in October 1993. The inclusion of maize grain yield into the PCA increased the total variance explained to $89 \%$ (Table 36). Thus, maize grain yield did not contribute much to explaining the total variance in the data set. Individual parameters did also not show strong correlations with crop yields and nutrient uptake. However, by including grain yield into the PCA it was possible to visualize which of the soil variables were the most important for maize cropping without fertilizer input on the two differentially degraded sites.

The main difference to the PCA run without maize was that grain yield was loading on the third PC and pot- $\mathrm{N}_{\min }$ parameters were removed and relocated into the first PC. The first PC was described by an association between CEC, exchangeable cations ( $\mathrm{Zn}, \mathrm{Ca}, \mathrm{K}, \mathrm{Mg}$ ), $\mathrm{NH}_{4}-\mathrm{N}, \mathrm{C}-\mathrm{N}$-ratio, organic and available $\mathrm{P}$, organic $\mathrm{C}$, soil enzyme activities (alkaline phosphatase, B-glucosidase and protease) and soil $\mathrm{pH}$, which form one set of variables and potential $\mathrm{N}$ mineralization parameters in the other set. Therefore, the first PC was characterized by enzyme-related nutrient dynamics and SOM-related cation exchange. The association of SMB-related variables, $\mathrm{NO}_{3}-\mathrm{N}$ and $\mathrm{C}-\mathrm{N}$-ratio with the second $\mathrm{PC}$ explained $14 \%$ of the variance in the data set. The second PC was interpreted as being the outcome of microbial degradation of SOM, which is by then affecting mineral $\mathrm{N}$ supply.

Maize grain yield across both sites was loading together with SOM-related variables such as total $\mathrm{N}$, acid phosphatase activity, protease activity, B-glucosidase activity, organic $\mathrm{C}$, soil $\mathrm{pH}$, exchangeable $\mathrm{Mg}$ and $\mathrm{K}$ and organic $\mathrm{P}$, explaining $32 \%$ of the variance.

Principal component scores differentiated clearly between the control plots of the two sites according to their initial status of soil degradation (Table 37). The two fields were strongly separated by the first and third PC whereas SMB-dynamics (PC 2) did only slightly differentiate among the fields. The control plots of the non-degraded $\mathrm{CH} 1$ site had positive scores for the first and third PC. At the degraded $\mathrm{CH} 2$ site, negative scores for these PCs indicated that at this site lower nutrient release by SOM mineralization was the main factor for lower maize yield. The positive scores for SMB-dynamics indicate that here microbial biomass turnover was more important than at the non-degraded $\mathrm{CH} 1$ site. 
Table 36: Principal components (PC) and varimax-rotated component loadings extracted from 21 initial soil parameters of the control $(0-30 \mathrm{~cm}$ soil layer $)$ and maize grain yield averaged across $\mathrm{CH} 1$ and $\mathrm{CH}$ 2. Soil sampling: 13. 06. 93.

\begin{tabular}{|c|c|c|c|}
\hline \multirow[t]{2}{*}{ Variables } & \multicolumn{3}{|c|}{ Principle Component (PC) } \\
\hline & 1 & 2 & 3 \\
\hline pot- $\mathrm{N}_{\min }(\mathrm{AN})^{1}$ & $\underline{-0.92}$ & 0.07 & -0.31 \\
\hline pot- $\mathrm{N}_{\text {min }} / \mathrm{N}_{\text {tot }}(\mathrm{AN})^{1}$ & $\underline{-0.90}$ & 0.28 & -0.20 \\
\hline exchangeable Zn & $\underline{0.85}$ & 0.12 & 0.42 \\
\hline alkaline phosphatase activity (alkal) & $\underline{0.85}$ & 0.07 & 0.50 \\
\hline $\mathrm{CEC}$ & $\underline{0.80}$ & 0.11 & 0.58 \\
\hline exchangeable $\mathrm{Ca}$ & $\underline{0.75}$ & -0.05 & 0.58 \\
\hline $\mathrm{NH}_{4}-\mathrm{N}$ & $\underline{0.75}$ & -0.06 & 0.50 \\
\hline exchangeable $\mathrm{K}$ & $\underline{0.74}$ & 0.16 & $\underline{0.62}$ \\
\hline organic $\mathrm{P}\left(\mathrm{P}_{\text {org }}\right)$ & $\underline{0.72}$ & 0.08 & $\underline{0.63}$ \\
\hline C-N-ratio & $\underline{0.72}$ & $\underline{0.65}$ & -0.02 \\
\hline exchangeable $\mathrm{Mg}$ & $\underline{0.70}$ & -0.02 & $\underline{0.70}$ \\
\hline available $\mathrm{P}\left(\mathrm{P}_{\text {avail }}\right)$ & $\underline{0.70}$ & -0.02 & 0.23 \\
\hline organic $\mathrm{C}\left(\mathrm{C}_{\mathrm{org}}\right)$ & $\underline{0.67}$ & 0.13 & $\underline{0.72}$ \\
\hline ß-glucosidase activity (ß-gluc) & $\underline{0.64}$ & 0.24 & $\underline{0.72}$ \\
\hline protease activity (prot) & $\underline{0.63}$ & -0.03 & $\underline{0.76}$ \\
\hline $\mathrm{pH}$ & $\underline{0.61}$ & -0.14 & $\underline{0.65}$ \\
\hline extractable sulfate-S & $\underline{0.60}$ & 0.14 & 0.15 \\
\hline microbial biomass $\mathrm{C}\left(\mathrm{C}_{\text {mic }}\right)$ & 0.20 & $\underline{0.94}$ & 0.10 \\
\hline $\mathrm{C}_{\text {mic }}-\mathrm{C}_{\text {org }}$-ratio & -0.11 & $\underline{0.90}$ & -0.24 \\
\hline $\mathrm{NO}_{3}-\mathrm{N}$ & -0.39 & $\underline{0.68}$ & 0.45 \\
\hline$\underline{\text { maize grain yield }}^{2}$ & 0.38 & 0.03 & $\underline{0.89}$ \\
\hline total $\mathrm{N}\left(\mathrm{N}_{\mathrm{tot}}\right)$ & 0.17 & -0.35 & $\underline{0.86}$ \\
\hline acid phosphatase activity (acid) & 0.28 & 0.42 & $\underline{0.78}$ \\
\hline percentage of total variance explained & 43 & 14 & 32 \\
\hline
\end{tabular}

${ }^{1}$ Potential $\mathrm{N}$ mineralization after anaerobic incubation, ${ }^{2}$ harvested at the end of the $1^{1 \mathrm{st}}$ season in October 1993.

Table 37: Component scores calculated on initial soil data of the control plots including maize grain yield and their assignment to the first, second and third PC at $0-30 \mathrm{~cm}$ soil depth in June 1993. Location $\mathrm{CH} 1$ and $\mathrm{CH} 2$.

\begin{tabular}{lccc}
\hline & PC 1 & PC 2 & PC 3, \\
\hline CH 1 (non-degraded) & 0.70 & -0.18 & 0.46 \\
CH 2 (degraded) & -0.70 & 0.18 & -0.46 \\
\hline
\end{tabular}


In Figure 13 it is clearly visualized that maize grain yield across sites was positively associated with high SOM-related and enzymatically-driven nutrient dynamics at the non-degraded $\mathrm{CH} 1$ site whereas at the degraded $\mathrm{CH} 2$ site maize production was strongly associated with $\mathrm{N}$ mineralization potential.

Higher grain yield at $\mathrm{CH} 1$ was interpreted as a reflection of higher mineralization of SOM due to higher soil enzyme activities and higher nutrient supply (N, P, K, Ca, Mg, S, Zn). Since organic $\mathrm{C}$, total $\mathrm{N}$ and organic $\mathrm{P}$ represent the more stable SOM pool and enzyme activities reflect metabolic activity in soil, it can be concluded that maize cropping without fertilizer input is depleting the SOM nutrient reserves and thus contributing to overall soil degradation, even at low yield levels.

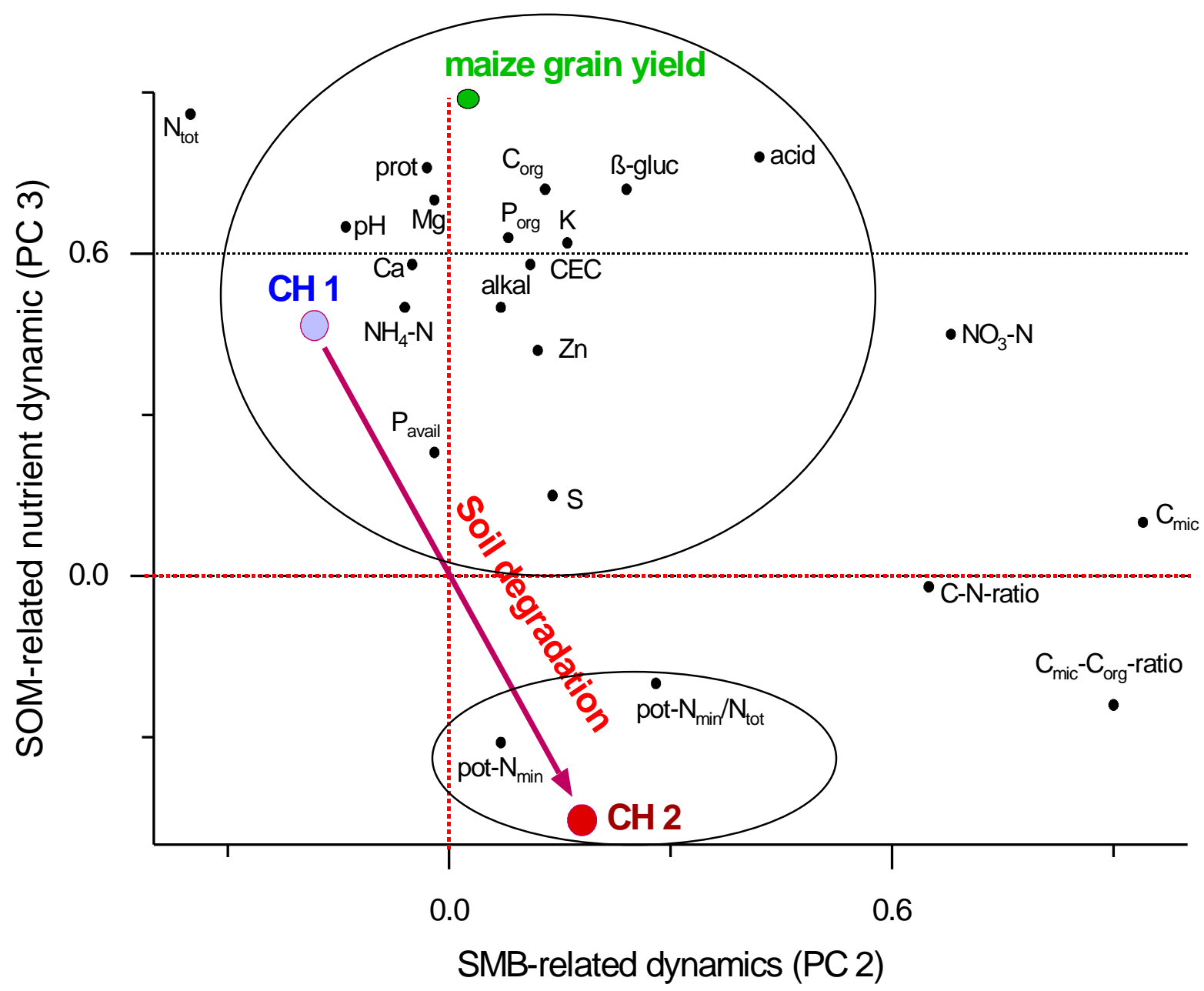

Figure 13: Second and third PC of a PCA on the control plots and assignment of the study sites ( $\mathrm{CH} 1$ and $\mathrm{CH} 2)$ to the PCs. PCA was computed on initial soil data at $0-30 \mathrm{~cm}$ soil depth in June 1993 including maize yield from October 1993. 


\subsubsection{Soil quality as affected by fertilizer management of sequential maize cropping}

A PCA was computed on soil characteristics across sites and treatments from June 1995 to identify the main determinants on preseason soil quality as affected by two years of maize cropping with varying fertilizer inputs on the two sites. Maize grain yield from October 1995 was included in the data set. The PCA suggested a similarity in the soil processes in the top layer with those of the first sampling date (June 1993).

Four PCs were extracted explaining $80 \%$ of the variance in the data set (Table 38). The first PC accounted for nearly half of the variance (47\%) and characterized again "SOM-dynamics". The second PC (15\%) had high loadings of maize grain yield together with $\mathrm{N}$ mineralization potential (pot- $\left.\mathrm{N}_{\min }\right)$ and soil mineral $\mathrm{N}$ content $\left(\mathrm{N}_{\min }\right)$. Consequently, the second factor was interpreted as "N-dynamics". The third PC (9\%) was dominated by $\mathrm{C}_{\text {mic }}$ and $\mathrm{C}_{\text {mic }}-\mathrm{C}_{\text {org }}$-ratio reflecting the role of the labile pool of SOM. Hence, it was named "SMB-dynamics". The fourth PC (9\%) had high loading of organic C and a relatively high loading of C-N-ratio. This PC, thus reflects the stable SOM-pool.

The main difference to the PCA run on initial soil data (Table 35) was that organic $\mathrm{C}$ was removed from the first PC and relocated on the fourth PC. The loading of the $\mathrm{C}-\mathrm{N}$-ratio on the fourth PC is not surprising, because SOM mineralization is partly determined by C-N-ratio. However, soil C-N-ratio was also loading high on the first PC which was interpreted as enzymatically-driven SOM-related nutrient dynamics. This observation is not contradictory, but emphasizes that the decomposition processes of SOM and microbial nutrient turnover were both affected by the C-N-ratio and thus by the quality of SOM.

By computing PC scores it was demonstrated that two years of consecutive maize cropping with different fertilizer management resulted in strong residual effects on soil processes at the beginning of the third season at both sites (Table 39). Scores clearly differentiate between the two sites with respect to their stages of soil degradation.

\section{The most striking feature of the data set was, that}

(1) at both sites SOM-dynamics (PC 1) did not respond to the fertilizer inputs,

(2) discrimination among fields in terms of SOM-dynamics was reflecting different stages of soil degradation at the beginning of the third year. 
Table 38: Principal components and varimax-rotated loadings extracted from preseason parameters of the top soil $(0-30 \mathrm{~cm})$ across $\mathrm{CH} 1$ and $\mathrm{CH} 2$ at the beginning of the third season (June 1995) including maize grain yield from October 1995.

\begin{tabular}{|c|c|c|c|c|}
\hline \multirow[t]{2}{*}{ Variables } & \multicolumn{4}{|c|}{ Principle Components (PC) } \\
\hline & 1 & 2 & 3 & 4 \\
\hline CEC & $\underline{0.96}$ & 0.11 & -0.02 & 0.12 \\
\hline exchangeable $\mathrm{Ca}$ & $\underline{0.95}$ & -0.05 & -0.01 & 0.09 \\
\hline alkaline phosphatase activity & $\underline{0.93}$ & -0.10 & 0.06 & 0.13 \\
\hline $\mathrm{pH}$ & $\underline{0.90}$ & -0.25 & 0.10 & 0.09 \\
\hline organic $\mathrm{P}$ & $\underline{0.89}$ & -0.02 & 0.14 & 0.03 \\
\hline acid phosphatase activity & $\underline{0.87}$ & 0.13 & 0.05 & 0.07 \\
\hline total $\mathrm{N}$ & $\underline{0.86}$ & 0.14 & -0.09 & -0.37 \\
\hline B-glucosidase activity & $\underline{0.85}$ & 0.28 & -0.18 & 0.16 \\
\hline extractable sulfate-S & $\underline{0.74}$ & 0.13 & 0.29 & 0.10 \\
\hline exchangeable Zn & $\underline{0.72}$ & 0.31 & -0.16 & 0.14 \\
\hline C-N-ratio & $\underline{-0.70}$ & -0.08 & -0.01 & $\underline{0.68}$ \\
\hline exchangeable $\mathrm{Mg}$ & $\underline{0.68}$ & 0.40 & -0.17 & 0.23 \\
\hline protease activity & $\underline{0.68}$ & 0.31 & -0.10 & 0.03 \\
\hline exchangeable $\mathrm{K}$ & $\underline{0.63}$ & 0.49 & 0.09 & 0.21 \\
\hline pot- $\mathrm{N}_{\min } / \mathrm{N}_{\text {tot }}(\mathrm{AN})^{1}$ & $\underline{-0.62}$ & 0.56 & 0.19 & 0.34 \\
\hline mineral $\mathrm{N}$ & -0.02 & $\underline{0.83}$ & 0.03 & 0.04 \\
\hline pot- $\mathrm{N}_{\min }(\mathrm{AN})^{1}$ & 0.15 & $\underline{0.82}$ & 0.15 & 0.12 \\
\hline$\underline{\text { maize grain yield }}$ & 0.15 & $\underline{0.80}$ & 0.28 & 0.02 \\
\hline organic carbon & 0.43 & 0.07 & -0.05 & $\underline{0.83}$ \\
\hline available $\mathrm{P}$ & 0.12 & 0.27 & -0.11 & 0.50 \\
\hline $\mathrm{C}_{\text {mic }}-\mathrm{C}_{\text {org }}$-ratio & -0.28 & 0.20 & $\underline{0.88}$ & -0.13 \\
\hline microbial biomass $\mathrm{C}$ & 0.33 & 0.25 & $\underline{0.85}$ & -0.04 \\
\hline percentage of total variance explained & 47 & 15 & 9 & 9 \\
\hline
\end{tabular}

${ }^{1}$ Potential $\mathrm{N}$ mineralization after anaerobic incubation

At the degraded CH 2 site, strong negative PC scores on SOM-dynamics across all treatments indicated further soil degradation due to continuous maize cropping.

This negative trend towards a continuous decrease in SOM and in its related soil nutrient dynamics could not be reversed in the short-term, not even with application of high amounts of combined mineral and organic fertilizer. 
Table 39: Component scores of fertilizer treatments and their assignment to the first, second, third and fourth principal component at $0-30 \mathrm{~cm}$ soil depth at the beginning of the third experimental year in June 1995. Location CH 1 and CH 2.

\begin{tabular}{lcccc}
\hline Treatment & $\begin{array}{c}\text { PC 1 } \\
\text { SOM-dynamics }\end{array}$ & $\begin{array}{c}\text { PC 2 } \\
\text { N-dynamics }\end{array}$ & $\begin{array}{c}\text { PC 3 } \\
\text { SMB-dynamics }\end{array}$ & $\begin{array}{c}\text { PC 4 } \\
\text { Stable SOM-pool }\end{array}$ \\
\hline CH 1 (non-degraded) & & & & \\
All & & & & \\
All org & 0.74 & 0.40 & 0.43 & 0.61 \\
-N & 0.83 & 1.40 & 0.22 & -0.02 \\
org & 0.97 & $-0.84^{\mathrm{a}}$ & 0.47 & -0.01 \\
control & 0.98 & -0.36 & -0.53 & 0.25 \\
CH 2 (degraded) & 0.75 & -1.53 & -0.26 & -0.33 \\
All & & & & \\
All org & -0.70 & 0.65 & 0.10 & 0.39 \\
-N & -0.85 & 1.08 & 0.43 & -0.39 \\
org & -0.93 & -0.35 & -0.89 & 0.78 \\
control & -0.89 & 0.11 & 0.48 & -0.33 \\
\hline
\end{tabular}

${ }^{a}$ negative component scores are printed in bold type

At the non-degraded $\mathrm{CH} 1$ site, SOM-dynamics had positive PC scores across all treatments. Therefore, it is concluded that SOM-related functional abilities were not negatively affected by two years consecutive maize cropping. Scores assigned to the second, third and fourth PC discriminated between different fertilizer management of the past two cropping seasons. The XY-ordination of the PC scores visualize more clearly the differences between the two fields. Moreover, soil parameters which are affecting maize grain yield and determining soil quality are directly linked to fertilizer management.

The scores on labile SOM pools as reflected by SMB- and N-dynamics, underlined the similarity of related soil processes at both sites. Without $\mathrm{N}$ fertilizer input and in the control, N- dynamics had negative scores at both sites, however, they improved upon mineral (All) and mineral plus organic (All org) fertilizer inputs as indicated by positive scores (Figure 14).

The SMB-dynamics (PC 3) was characterized by negative scores in the control, that increased upon fertilizer input, resulting in positive PC scores at both sites (Figure 15). 


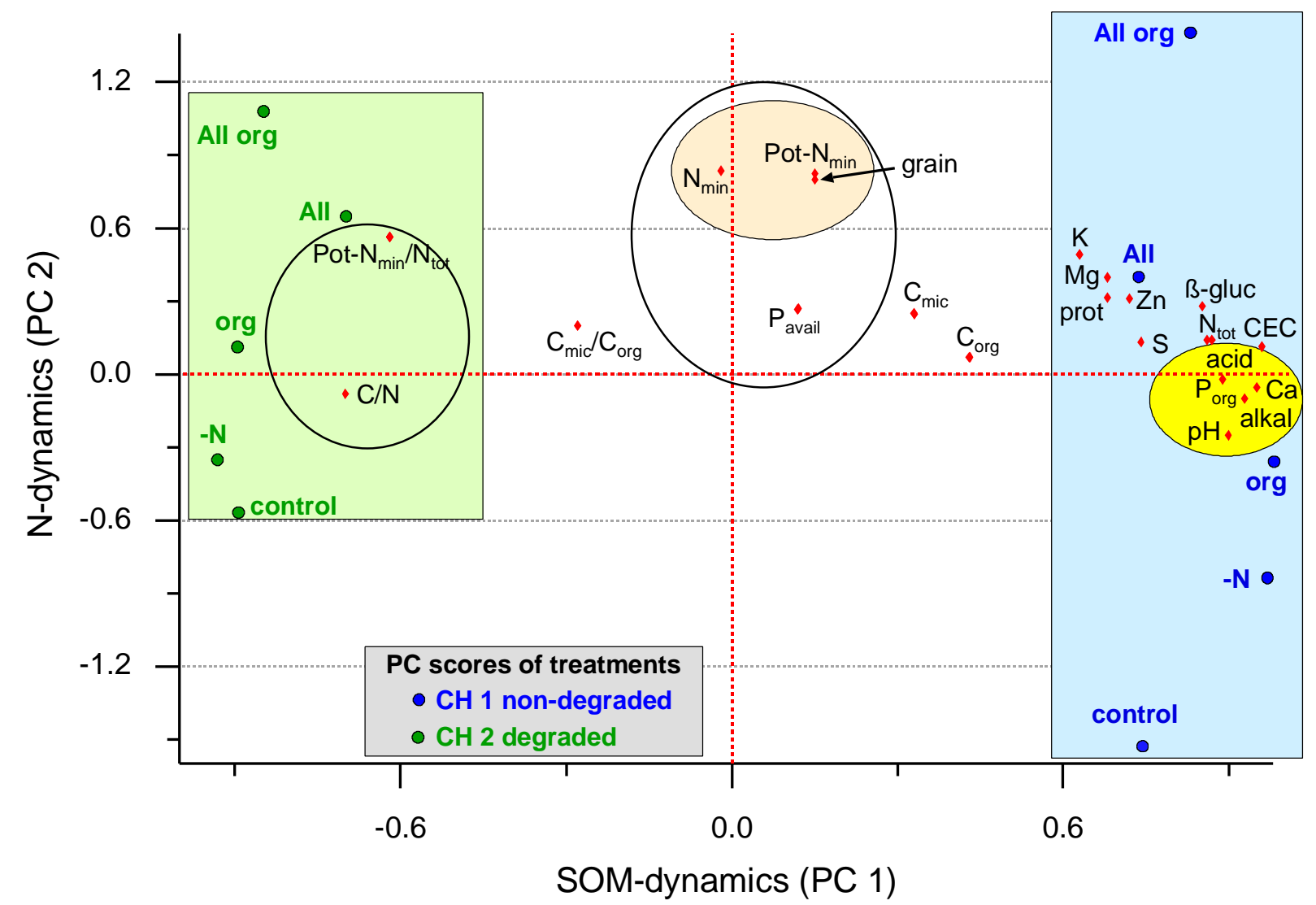

Figure 14: First and second PC of a PCA on soil samples at the beginning of the third season (June 1995) including maize grain yield (October 1995) and assignment of the treatments and sites to the PCs. Locations: $\mathrm{CH} 1, \mathrm{CH} 2(0-30 \mathrm{~cm}$ depth).

At the degraded CH 2 site, SMB-dynamics had strongest negative PC scores in the (-N) treatment which is an indication that at this site microbial growth was limited by available $\mathrm{N}$ in soil. In contrast, the positive scores on SMB-dynamics at $\mathrm{CH} 1$ indicate that microbial growth was not affected by inorganic $\mathrm{N}$ supply. However, the negative PC scores on $\mathrm{N}$-dynamics in the $-\mathrm{N}$ treatment (Figure 14) show that in the non-degraded $\mathrm{CH} 1$ soil microbial growth inhibited $\mathrm{N}$ mineralization.

Compared to treatment (All), N-dynamics improved substantially with cotton seed waste plus inorganic fertilizer indicating limited available $C$ sources in soil (Figure 14). With cotton seed waste as sole fertilizer (org), N-dynamics were reduced at $\mathrm{CH} 1$ as shown by negative scores. In this treatment, microbial growth and turnover was stimulated due to increasing substrate supply, however, it can be assumed, that with cotton seed waste application alone, $\mathrm{N}$ supply was not sufficient for maize and soil microorganisms, which were involved in $\mathrm{N}$ mineralization processes. 


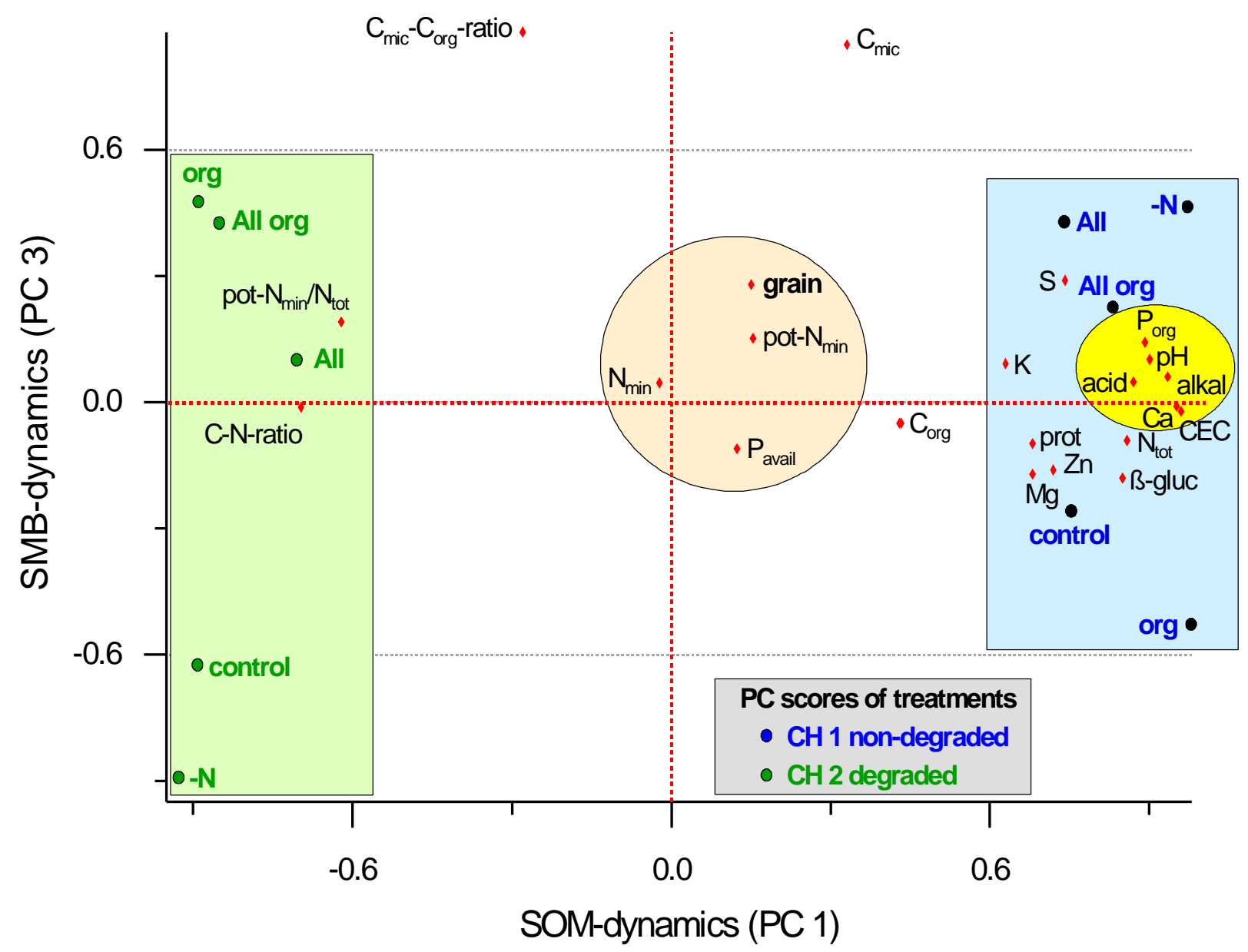

figure 15: First and third PC of a PCA on soil samples at the beginning of the third season (June 1995) including maize grain yield (October 1995) and assignment of the treatments and sites to the PCs. Locations: $\mathrm{CH} \mathrm{1,} \mathrm{CH} 2$ (0 - $30 \mathrm{~cm}$ soil depth).

A similar trend was observed at the degraded $\mathrm{CH} 2$ site, however $\mathrm{N}$-dynamics remained slightly positive as compared to the more fertile $\mathrm{CH} 1$ site. Cotton seed waste application as a sole input (org) had the strongest negative scores on SMB-dynamics at the non-degraded $\mathrm{CH} 1$ site but the highest positive scores at the degraded $\mathrm{CH} 2$ site (Figure 15). This may indicate that at $\mathrm{CH} 1$ microbial turnover and at $\mathrm{CH} 2$ microbial growth was stimulated by application of these organic wastes.

Scores to the fourth PC, were negative in the control at both sites (Table 39). This was attributed to depletion of SOM nutrient reserves under maize cropping without fertilizer input. With cotton seed waste either alone (org) or combined with inorganic fertilizer (All org), the assignment of PC scores to the fourth PC was below average at $\mathrm{CH} 2$. 
Slightly negative scores were also obtained with combined fertilization (All org) at the non-degraded $\mathrm{CH} 1$ site. At $\mathrm{CH} 2$ (degraded), cotton seed waste application generally promoted SMB-dynamics. It is assumed that, after labile-C supply the greater microbial activity could have induced higher decomposition of both $\mathrm{C}$ and $\mathrm{N}$ from the stable SOM-pool to compensate for higher nutrient demand by microorganisms and maize plants. Thus, negative PC scores on labile SMB-dynamics at CH 1 and on the stable SOM-pool assigned with the use of cotton seed waste might be interpreted as a "priming effect".

Strongly negative PC scores on the stable SOM pool, even with high input such as combined mineral plus organic fertilization (All org) indicated not only a depletion of the SOM nutrient reserves, but overall degradation of SOM-related soil functions at the degraded $\mathrm{CH} 2$ site.

The data clearly showed that fertilizer use is necessary to overcome SOM-related nutrient constraints in soil. However, the results presented in Table 39 also stressed that with fertilizer inputs only labile SOM-related pools could be improved on the short-term. Moreover, it was demonstrated that continuous maize cropping on an already degraded soil will further contribute to soil degradation, even with high mineral and organic fertilizer input. The differences between the (-N) treatments and the control illustrated that besides $\mathrm{N}$ limitations also other factors must have contributed to lower $\mathrm{N}$-dynamics and strong degradation of the stable SOM-pool in the control at both sites. Less available nutrients and available $\mathrm{N}$ in particular, are considered main limitations for $\mathrm{N}$-dynamics.

Substrate availability was suggested to be the main limiting factor on SMB-dynamics. Lower plant biomass production of maize (Table 10) and preseason fallow (weed) regrowth (Annex, Table 50) left lower amounts of crop residues in the soil which could be used by microorganisms as substrates in the control plots. Hence, it is concluded that in the control at the non-degraded $\mathrm{CH} 1$ site severe substrate and nutrient limitations must have contributed to a substantial reduction of the microbially mediated soil processes. However, SOM-related nutrient dynamics (PC 1) of the control at $\mathrm{CH} 1$ were described by above average. The results indicate that at this site SOM-dynamics are more stable and controlling key functions in the soil, without showing much sensitivity to short-term changes due to different input management. 
Maize grain yield was most closely associated with $\mathrm{N}$ mineralization potential, soil mineral $\mathrm{N}$, but also with available $\mathrm{P}$. These findings confirm that major constraints for achieving higher maize grain yields are $\mathrm{N}$ deficiency at $\mathrm{CH} 1$ and both, $\mathrm{N}$ and $\mathrm{P}$ deficiency at $\mathrm{CH} 2$. As shown in Table 34 and discussed in chapter 5.6, preseason inorganic $\mathrm{N}$ content combined with determination of a soil fraction that is related to $\mathrm{N}$ mineralization is the best predictor for maize grain yield.

From Figure 14 and 15 it was also visible that at $\mathrm{CH}$ 1, activity of phosphatases clustered closely together with soil organic $\mathrm{P}$ content and soil $\mathrm{pH}$. This is an indication for better P-cycling at the non-degraded $\mathrm{CH} 1$ site. Protease and B-glucosidase activity, exchangeable $\mathrm{Zn}$ and $\mathrm{Mg}$, and $\mathrm{N}_{\text {tot }}$, were closely associated on PC 1 at $\mathrm{CH} 1$. Generally, higher protease activity reflects higher proteolytic potential and thus, higher protein degradation capacity, which is an important step in N-cycling (TRASAR-CEPEDA, 1998). Higher B-glucosidase activity indicated higher potential to hydrolyze carbohydrates and release glucose, which is improving energy supply for soil microorganisms (BURKET and DICK, 1998). The combination of $\beta$-glucosidase and protease activity best represents that both, the release of mineral $\mathrm{N}$ and of available $\mathrm{C}$ from SOM fractions were the main sources for microbes for covering their $\mathrm{N}$ and energy demand to carry out SOM mineralization. Thus, both enzymes were biologically relevant to processes of $\mathrm{N}$ - and $\mathrm{C}$-cycling in soil.

At the highly degraded $\mathrm{CH} 2$ site, SOM-dynamics had negative PC scores, although mineral and/or organic fertilizer have been applied (Figure 14 and 15). Variables characterizing soil processes at $\mathrm{CH} 2$ such as the proportion of total $\mathrm{N}$ that is mineralizable (pot- $\mathrm{N}_{\text {min }} / \mathrm{N}_{\text {tot }}$ ), C-N-ratio and $\mathrm{C}_{\text {mic }}-\mathrm{C}_{\text {org }}$-ratio were related to decomposition of stable organic $\mathrm{N}$ and are describing quality of SOM. This indicated that maintenance of SOM at this site was not possible in the short-run, even not with high fertilizer input.

In conclusion, at the degraded $\mathrm{CH} 2$ site, short-term nutrient supply for maize and microorganisms could be improved upon fertilizer management, however, this did not increase overall SOM content. The negative PC scores assigned with the stable SOM-pool in the combined fertilized plots (All org) and after the use of cotton seed waste (org), confirmed that application of easily available organic $\mathrm{C}$ such as cotton seed waste might lead to a "priming effect" and boost SOM decomposition. However, without fertilizer input the depletion of this pool was much more severe. 


\subsubsection{Biochemical and biological parameters as soil quality indicators}

The PCA-method showed that microbiological-driven dynamics in soil are complex interactions of physical, chemical and biological components in the soil and that soil microorganisms are important biological agents in this agricultural ecosystem. The PCA identified the main soil processes by integrating soil chemical and microbiological variables. In these soil processes fundamental biological properties such as soil enzyme activities, $\mathrm{SMB}$ and $\mathrm{N}$ mineralization play an important role, were indicative of soil degradation status and sensitive to variations in fertilizer management.

Soil microbial biomass comprises a substantial pool of nutrients, but the extent to which the microrganisms compete with the plant for soil nutrients could not clearly be established. Under the prevailing experimental conditions SOM-related nutrient dynamics were identified as the most critical processes in describing soil quality. The associated biochemical and microbial properties were suitable indicators to assess biological activity. Soil microbial biomass and $\mathrm{N}$-dynamics reflected labile soil processes which reacted more sensitive to different management practices than the more stable SOM-dynamics did.

Soil organic C levels provided a good indication of the general productivity or potential sustainability of an agricultural savanna soil. The low inherent organic $\mathrm{C}$ content of the study soils contributed to rapid soil degradation. Management factors influencing the decrease or increase in $\mathrm{C}$ and $\mathrm{N}$ stocks in soils could be mineral and organic fertilizer use, stimulating of microbial activities in soil. Soil microbial biomass and soil enzyme assays were good indicators of the intensity of soil microbial activity and were suitable early indicators of changes in SOM.

The most striking feature of the study was that three years of sequential maize cropping on a degraded soil, without mineral and/or organic fertilizer input, led to continued soil degradation with decreasing soils' microbiological functioning. Soil processes were further influenced by management practices but also by environmental variations and climate. However, interpretation of the measured bioindicators with respect to sustainability of land-use was difficult due to the fact of missing long-term data, defined local standards or a reference soil and threshold levels. For defining the sustainability of agricultural systems monitoring of both, short- and long-term changes in soil quality of savanna soils is necessary. More insight information can be obtained from long-term studies and field evaluations in addition to experiments under more controlled conditions. 


\subsection{Relationships between soil quality and sustainable crop production}

Bush fallow systems are the prevailing land use systems for small scale farmers in the savanna region of northern Ghana. In the traditional systems, a fallow of ten to fifteen years alternated with a cultivation period of four to six years (HESSE, 1997). Due to increasing land pressure the fallow was reduced to two years in the study region (KRANZ et al., 1998). The natural fallow vegetation is consisting of a spontaneously growing vegetation dominated by grasses. The short fallow periods are considered, ineffective to maintain productivity of the soils as soil analysis and crop yields have shown. JOST (1997) and KRANZ et al. (1998) considered fallow periods of these systems too short to restore soil fertility status, at least to a level that allows the farmers to reach sustainable and stable crop yields on a higher level ( $>1 \mathrm{t} \mathrm{ha}^{-1}$ maize grain yield). Moreover, the common cropping systems are severely lacking in stability and cause increasing soil degradation.

The main reasons are

(1) loss of SOM and plant nutrients due to permanent nutrient mining and annual bush fires,

(2) deterioration of physical structure

(3) and decline of biological activity of the soil.

A rehabilitation of soil fertility can only be achieved if the land is abandoned and left as fallow field. However, this natural regeneration process might take up to ten to fifteen years or even more and is only possible, where new land for cultivation is available. With regard to increasing land scarcity in many areas in northern Ghana, new and suitable methods for soil restoration have to be introduced to the farmers.

The long-term use of chemical fertilizers in intensive agriculture can cause severe soil acidification, which is often related to the loss of SOM. As a consequence, soil fertility restoration would best be closely connected to the replenishment of SOM. This can be achieved by using organic inputs, which provide both $\mathrm{C}$ and $\mathrm{N}$. Inorganic fertilizer increase crop residues and may thus provide $\mathrm{C}$ to the soil. 
Using manure soil acidification due to the use of mineral $\mathrm{N}$ fertilizer can be reduced or avoided. However, large quantities of organic manure are needed to provide the nutrients in mineral fertilizer and such quantities are often not available. In general, the use of manure is irregular and not systematic, often limited to small areas and very often below agronomically efficient amounts (HESSE, 1997). However, there is no doubt that manure can play an important role in recycling nutrients, help to increase crop yields and to conserve SOM content.

Therefore, only by a combination of crop residue restitution, fallowing, or green manuring together with application of inorganic fertilizers, organic manures or mulches, crop yields and soil fertility may be maintained or improved in the long run. Nutrient replacement fertilization should be the farmers' general practice to compensate for losses due to removal and leaching. Apart from $\mathrm{N}$ and $\mathrm{P}$, farmers should monitor $\mathrm{K}, \mathrm{Mg}$ and $\mathrm{Zn}$. Moderate amounts of $\mathrm{N}, \mathrm{P}, \mathrm{K}$ and eventually $\mathrm{Mg}, \mathrm{S}$ and $\mathrm{Zn}$ are necessary to meet nutrient demands of crops at certain target yields and to overcome permanent nutrient mining. The efficiency of mineral fertilizer can often be increased by adding organic compounds from internal nutrient sources (e.g. green manures, farmyard manures, organic wastes).

In the current cropping systems, removal of crop residues from the field is very common. However, the return of crop residues is considered essential and must be the first objective if sustainability is to be achieved with traditional cropping systems where little $\mathrm{N}, \mathrm{P}$ and $\mathrm{K}$ or none is added. In a low-input cropping system removing only the grain about $40 \%$ of the N, $25 \%$ of the P, $50 \%$ of the $\mathrm{Zn}$ and more than half of the $\mathrm{K}, \mathrm{Ca}$, and $\mathrm{Mg}$, are recycled to the soil via crop residues.

The development of an integrated plant nutrition management system which is adopted to site characteristics is suggested. This approach in which the management of plant nutrition and soil fertility in farming systems includes efficient mineral fertilizer use in combination with all kinds of organic sources seems to be a promising approach to overcome soil fertility constraints in the savanna soils in Northern Ghana. There is a great variety of possible combinations and of nutrient sources at the level of the farmers. The management of different sources of nutrients needs to be assessed and farmers needs to be trained in applying this new approach. 


\subsection{Modifications of current land-use systems for soil fertility maintenance}

For the small-scale farmer, intercropping or mixed cropping provides his food-security and income even in the unpredictable rainfall regimes and eroded soil conditions. Intercropping seems useful to subsistence farmers because they use only little or no fertilizers. Farmers attempt to satisfy family consumption needs by expanding the crop area into more marginal zones (SALIFU, 1993). In fact, increases in crop production were mainly achieved due to cultivation of new land (IFDC, 1994). As a consequence, yield levels remain low, soil fertility is decreasing and soil degradation is increasing.

In order to combat soil fertility constraints at the farmers' level the application of fertilizer and manure might be one measure to maintain soil fertility if fallowing can no longer be practiced and fallow land is not available. However, maintaining soil fertility may require the introduction of alternative crops in selected cropping systems. Such improved systems could be based on the integration of leguminous cover crops as green manures in an attempt to optimize the soil internal cycling efficiency. In the study area, the integration of one-year improved fallow with leguminous cover crops has shown to be of great potential and is considered a good possibility to improve cereal production (JosT, 1997). Yield of sorghum was much higher after improved fallow management with herbaceous leguminous Calopogonium mucunoides and Pueraria phaseoloides as improved one-year fallow systems than the natural bush fallow regrowth. Improved fallow management with calopogonium and pueraria resulted in higher $\mathrm{N}, \mathrm{P}, \mathrm{Ca}$, and $\mathrm{Mg}$ accumulation in the above ground plant biomass, even in the first year, whereas the natural gras fallow control showed higher K accumulation (FUGGER and VLEK, 1998). After one year, calopogonium accumulated $97-109 \mathrm{~kg} \mathrm{~N} \mathrm{ha}^{-1}$ compared to pueraria with $55-80 \mathrm{~kg} \mathrm{~N} \mathrm{ha}^{-1}$ and bush fallow regrowth with $35-38 \mathrm{~kg} \mathrm{~N}$ ha ${ }^{-1}$. Subsequent maize benefited significantly from a one-year calopogonium fallow with higher total maize biomass $\left(3.6-4.2 \mathrm{t} \mathrm{ha}^{-1}\right)$ and grain yield $\left(2.1 \mathrm{t} \mathrm{ha}^{-1}\right)$ compared to the natural bush fallow, which produced total maize biomass yields of $2.0-2.4 \mathrm{tha}^{-1}$ and grain yields of $0.9-1.1 \mathrm{t} \mathrm{ha}^{-1}$.

KOMBIOK et al. (1995) presented on-station results from SARI, revealing that after two years of calopogonium fallow, N, P and K in soil increased by 18, 65 and $43 \%$, respectively. Maize grain yield improved substantially when maize was planted into the mulch as compared to removal of cover crop by hoeing before planting the maize. 
The most important parameter of leguminous cover crops in relation to their usefulness for soil fertility maintenance is the amount of biomass it can produce and to suppress weed growth. Calopogonium and pueraria grown on two farmers' fields in the 1994 cropping season in the study area produced biomass yields between 8.4 and $9.0 \mathrm{t} \mathrm{ha}^{-1}$ for calopogonium and 6.0 and $6.5 \mathrm{t} \mathrm{ha}^{-1}$ for pueraria as compared to one-year natural gras fallow which produced between 8.7 and $9.5 \mathrm{t} \mathrm{ha}^{-1}$ (JosT et al., 1996). FosU (personal communication) reported biomass yields of $5-15 \mathrm{t} \mathrm{ha}^{-1}$ for crotolaria, and of 9 and $10 \mathrm{t} \mathrm{ha}^{-1}$ for mucuna and calopogonium, respectively, which were grown over the 1996 season in the study area. Calopogonium improved grain yield of maize more than $300 \%$ and crotolaria with the least biomass input more than doubled the grain yield above the one-year (weed) fallow.

According to ANANE-SAKYI (1995), legumes play an important role in farming systems in savanna zones of Ghana. They are widely used in crop rotation, intercropping, mulch and for nutrient recycling often with indigenous species. However, little information exists about their $\mathrm{N}$ fixation, nutrient contribution and nutrient recycling potentials and thus about their contribution to crop yield and soil fertility improvement. It should also be noted that high levels of $\mathrm{N}$ fixation in legumes and high biomass production of legumes can only be achieved if growing conditions and all essential nutrients for legume plant growth are optimal. Additional beneficial effects, such as reduced runoff and soil loss are expected when legumes are used as ground cover or mulch. In the savanna zone where soil erosion and soil degradation pose a serious threat, leguminous cover crops may provide an acceptable alternative to natural (weed) fallow.

Crop rotation has also been demonstrated to be an economically viable alternative cropping system over the traditional system of mixed cropping in terms of maintaining or improving productivity of soils (LANGYINTUO and DogBe, 1998). Several trials carried out on farmers' fields in northern Ghana indicated the importance of crop rotation to increase food production on savanna soils with low fertility. According to HAERDTER (1989) cowpea/maize rotation not only increased the grain yield due to higher nutrient efficiency as compared to monocrop but, also improved the physical properties of the soil. 
At SARI, long-term field data suggest the superiority of rotation over intercropping, particular without $\mathrm{N}$ fertilizers. After five consecutive years, groundnut was the best preceding crop for maize with an output of $3.4 \mathrm{t} \mathrm{ha}^{-1}$ of maize grain without $\mathrm{N}$ fertilizer. After groundnut and maize-groundnut intercrop, yam was the third best preceding crop for maize. Grain yields were $3.0 \mathrm{t} \mathrm{ha}^{-1}$ for maize-groundnut intercrop and $2.7 \mathrm{t} \mathrm{ha}^{-1}$ for yam (HAERDTER, 1989). In on-farm trials in the study area, grain and straw yields of maize and sorghum were significantly higher after growing soybean, groundnut, cowpea, sunflower and cotton for one or two consecutive years as preceding crops than after sorghum (SPRICH, 1994). Similar results were reported by JOST (1997) from on-farm trials in the study area, with higher sorghum grain and straw yields after preceding crops such as soybean and cotton for two years than with sorghum or bush fallow as preceding crop. Farmers are already involved in rotation of crops and other practices to improve soil fertility in certain areas in the Guinea savanna. Legume/cereal crop rotation or intercropping legume and non-legume is increasingly a more-common practice by the farmers (ANANE-SAKYI, 1995). This is confirmed by several surveys and personal communication with farmers in the study area during the study period from 1993 to 1996. However, the rotations are not optimized to give farmers maximum benefits. 


\subsection{Conclusions}

In our experiments with varying fertilizer management, maize grain yield of the control reflected productivity potential of soils and as such farmers' yields in the study area. On average across seasons, maize grain yields were $0.6 \mathrm{tha}^{-1}$ at the degraded site and $1.2 \mathrm{t} \mathrm{ha}^{-1}$ at the non-degraded site. Maize grain yield levels are a reflection of several interacting factors and can distinguish between contrasting study sites and different treatments.

The major constraints to higher maize yields in the Guinea Savanna of Ghana are low inherent $\mathrm{N}$ and $\mathrm{P}$ supplies by the soils. Nutrient concentrations and uptake in above ground maize biomass confirmed $\mathrm{N}$ and $\mathrm{P}$ deficiency and provides a good indication of what maize is able to extract from the soil under prevailing conditions.

Mineral fertilizer and cotton seed waste application increased maize grain yield and nutrient uptake. Under well managed conditions, grain yield increased up to $4-5 \mathrm{t} \mathrm{ha}^{-1}$ upon $100 \mathrm{~kg} \mathrm{~N} \mathrm{ha}^{-1}, 60 \mathrm{~kg} \mathrm{P} \mathrm{ha}^{-1}, 60 \mathrm{~kg} \mathrm{~K} \mathrm{ha}^{-1}$ and $25 \mathrm{~kg} \mathrm{Mg} \mathrm{ha}^{-1}$ on average across sites. With combined mineral and organic fertilizer grain yields ranged between 4.1 and $5.3 \mathrm{tha}^{-1}$ over the years and across sites. It is concluded that fertilizer application can compensate for nutrient deficiencies and differences in soil fertility.

The measured chemical and microbiological soil parameters and $\mathrm{N}$ mineralization indices can distinguish between degrees of soil degradation. Although chemical soil analysis are often good indicators of the macro-nutrient status of soils, they are not sensitive enough to indicate short-term management effects on soil quality and sustainability of the cropping system. Sequential maize cropping over three years in our experiments with varying fertilizer management did not affect total organic $\mathrm{C}$, organic $\mathrm{P}$ and total $\mathrm{N}$ in the soil. These parameters reflect the soils' nutrient reserves which are not sensitive to treatment effects.

Changes in total SOM due to differential fertilizer management practices are slow. To evaluate short-term changes in SOM, soil parameters that are reflecting the labile SOM pools may be more suitable. Additional determination of different SOM fractions would more detailed information about changes in SOM and nutrient supply.

Microbiological soil properties varied strongly with sampling date and fertilizer management. Soil microbial biomass and enzyme activities were generally lower at the degraded site. Here, also seasonal variation was lower. 
Microbial biomass was more sensitive to changes in fertilizer management than organic $\mathrm{C}$, organic $\mathrm{P}$ and total $\mathrm{N}$. The incorporation of organic materials and better plant growth due to mineral fertilizer raised the biomass $\mathrm{C}$ level and stimulated soil enzyme activities.

The $\mathrm{NH}_{4}{ }^{+}, \mathrm{NO}_{3}{ }^{-}$and $\mathrm{N}_{\text {min }}$ peaks indicated a good retention of the fertilizer- $\mathrm{N}$ in the soil profile. Fertilization increased $\mathrm{N}_{\min }$ content in the soil profile. Higher $\mathrm{N}_{\min }$ content in the deeper soil layers was attributed to leaching of $\mathrm{NO}_{3}{ }^{-}$. Preseason soil $\mathrm{NH}_{4}{ }^{+}, \mathrm{NO}_{3}{ }^{-}$and $\mathrm{N}_{\text {min }}$ at maize planting significantly correlated with grain yield and $\mathrm{N}$ uptake. Yield and $\mathrm{N}$ uptake was better related to $\mathrm{NO}_{3}{ }^{-}$than to $\mathrm{NH}_{4}{ }^{+}$.

$\mathrm{N}$-Mineralization data after aerobic incubation were suitable for modeling $\mathrm{N}$ release from soil organic $\mathrm{N}$. The model produced good predictions of $\mathrm{N}$ mineralization potential $\left(\mathrm{N}_{0}\right)$ in the studied soils. $\mathrm{N}_{0}$ is believed to represent a pool of readily-mineralizable $\mathrm{N}$ which would reflect the impact of soil type or management. Fertilizer use had a positive effect on $\mathrm{N}_{0}$.

Potential $\mathrm{N}$ mineralization after anaerobic incubation (pot- $\mathrm{N}_{\min }$ ) varied between sites, sampling dates, soil depth and treatments suggesting that this method is sensitive enough to detect changes in $\mathrm{N}$ availability. Pot- $\mathrm{N}_{\min }$ was significantly correlated with maize yield and $\mathrm{N}$ uptake. A combination of pot- $\mathrm{N}_{\min }$ with preseason $\mathrm{N}_{\min }$ content was the best predictor for maize grain yield and $\mathrm{N}$ uptake. Pot- $\mathrm{N}_{\min }$ is considered to be a suitable biological indicator.

Soil parameters were multicolinear and they were all considered of primary importance for soil quality. Principal component analysis (PCA) reduced the number of variables and the principal components reflected soil processes that played a significant role in explaining the variance in the data set and were related to soil quality.

Soil quality at the experimental sites was mainly determined by SOM content and SOMrelated nutrient cycling processes. Soil degradation was attributed to decreasing soil nutrient content $(\mathrm{N}, \mathrm{P}, \mathrm{K}, \mathrm{Mg}, \mathrm{S}, \mathrm{Zn})$ and at the same time to strong degradation of the stable SOM pool and microbiological mediated soil processes. As it was evident from PCA, sequential maize cropping on an already degraded soil contributes to enhanced degradation of the soils' organic nutrient reserves, even with high fertilizer input. Therefore, it is concluded that crop yield and nutrient uptake are incomplete measures in terms of soil quality. Evaluation of sustainability of a cropping system cannot be based on yield and nutrient uptake alone, but must consider soil quality as an integral factor of productivity. 
Savanna soils in Northern Ghana are very poor and without mineral fertilizer or organic amendments, these soils have a reduced potential to accomplish the important soil function of nutrient supply. Mineral fertilizer combined with cotton seed waste improved not only the nutrient status of the soil, but also biological and biochemical characteristics. The availability of organic substrates and soil nutrients such as mineral $\mathrm{N}$ control microbialrelated nutrient dynamics. It was shown by the PCA that microbial soil parameters are most closely associated to the changes undergone by SOM. Consequently, soil microbial biomass, soil enzyme activities of the $\mathrm{C}, \mathrm{N}$ and P-cycle and potential $\mathrm{N}$ mineralization indices appeared to provide a reliable tool to sense early changes in the dynamics.

In the Guinea Savanna zone in northern Ghana inadequate agricultural production has led to loss of soil fertility and soil degradation. Farmers' practices which contribute to soil degradation are short fallow periods, nutrient mining, bush burning and overgrazing of animals. In densely populated areas good farm land is becoming scarce. The use of inorganic fertilizers to compensate for nutrient mining is very low due to high fertilizer prices. Organic manure is only sparingly applied because it is not available in sufficient amounts. Cropping without replacement of the nutrients removed in the food crops will ultimately result in soil degradation and poor crop yields. As a consequence, nutrient deficiencies are widespread in the savanna areas in northern Ghana. A calculation of nutrient removal by harvest products and crop residues is therefore important for estimating a nutrient balance.

Besides management of crop residues, agriculture in this area with soils of low inherent fertility requires external inputs to avoid loss of soil quality and to achieve sustainability on a higher yield level. For a substantial increase in maize grain yields fertilizer $\mathrm{N}$ and $\mathrm{P}$ applications are crucial. Moreover, the drain on the stock of secondary nutrients such as $\mathrm{K}$ and $\mathrm{Mg}$ by maize in these soils is substantial. This might be especially important for $\mathrm{Mg}$ because the common NPK fertilizers used in West Africa do not contain Mg. However, the intensification with mineral fertilizer as the only source of $\mathrm{N}$ may lead to soil acidification which has a negative affect on soil productivity and sustainable crop production.

Crop yields and soil quality may be maintained or improved in the long run, only by an integrated plant nutrition management system which is adopted to site characteristics. This approach integrates measures such as crop residue restitution, improved fallow systems, green manuring together with efficient use of inorganic and organic fertilizers. 


\section{$7 \quad$ Summary}

The concept of soil quality integrates physical, chemical and microbial soil properties and relates them to sustainable production in agricultural systems. Reliable measure of soil quality requires the selection of soil parameters most sensitive to management practices. In accordance with this approach, besides chemical soil characteristics such as $\mathrm{pH}$, organic $\mathrm{C}$, total $\mathrm{N}$, organic and available $\mathrm{P}$, base saturation, $\mathrm{CEC}$, exchangeable cations $(\mathrm{K}, \mathrm{Ca}, \mathrm{Mg}, \mathrm{Mn}, \mathrm{Zn})$ and mineral $\mathrm{N}\left(\mathrm{NH}_{4}{ }^{+}, \mathrm{NO}_{3}{ }^{-}\right)$also microbiological properties such as soil microbial biomass, soil enzyme activities (ß-glucosidase, protease, acid and alkaline phosphatase), and $\mathrm{N}$ mineralization indices (aerobic and anaerobic laboratory incubation) were determined. The enzymes covered are those important in $\mathrm{C}, \mathrm{N}$ and $\mathrm{P}$ cycling in soils. The general objective of the research was to improve the understanding of nutrient cycling in the study soils.

This study was undertaken at the Savanna Agricultural Research Institute (SARI) in northern Ghana. From 1993 - 1995 two identical minus-one (missing-element) trials were carried out over three cropping cycles on two farmers' fields with contrasting degree of soil degradation. The main objective was to compare the productivity of the two sites and to identify those parameters that are affected most by soil and crop management. As test crop for low soil productivity maize (Zea mays L.) was used. To evaluate the potential for sustainable productivity, soil microbial and biochemical parameters were linked with crop productivity and soil quality conditions.

The experimental design was a single-factor trial with ten treatments repeated in five randomized complete blocks. In the first year, the elements $\mathrm{N}, \mathrm{P}, \mathrm{K}, \mathrm{Ca}, \mathrm{Mg}, \mathrm{S}$, and $\mathrm{Mo}$ were applied in the complete fertilized treatment (All). To detect limiting nutrients, subtractive treatments (-N, -P, -K, -Ca, - Mg, -S, -Mo) were included. In a combined fertilized treatment cotton seed waste $\left(2 \mathrm{t} \mathrm{DM} \mathrm{ha}^{-1}\right)$ was applied in addition to complete mineral fertilization (All org). In the first year $\mathrm{Zn}$ was applied across all plots.

The treatment pattern in 1994 and 1995 were modified based on results of 1993. Due to lacking response, the treatment (-Ca) was replaced by cotton seed waste (org) application at $2 \mathrm{t} \mathrm{DM} \mathrm{ha}^{-1}$ to evaluate the effect as a pure organic fertilizer. To check for possible $\mathrm{Zn}$ deficiency, the former (-Mo) was modified to the treatment without Mo and $\mathrm{Zn}(-\mathrm{Mo} /-\mathrm{Zn})$. The rate of $\mathrm{Zn}$ was reduced from 10 to $5 \mathrm{~kg} \mathrm{ha}^{-1}$. 
The top soils were sandy with moderately acid soil $\mathrm{pH}$. Base saturation was high with $\mathrm{Ca}$ and $\mathrm{Mg}$ as dominant cations. Soil parameters indicating initial soil quality differed strongly across sites. Significant differences between sites occurred for all the measured soil properties, except base saturation. Effective cation exchange capacity (CEC), exchangeable cations, organic $\mathrm{C}$, total $\mathrm{N}$, sulfate-S and Bray-I phosphorus (available $\mathrm{P}$ ) ranged at very low levels at the degraded $\mathrm{CH} 2$ site as compared to the non-degraded $\mathrm{CH} 1$ site. Except for soil $\mathrm{NO}_{3}{ }^{-}$content, all measured soil parameters had higher levels at $\mathrm{CH}$ 1. The initial soil analysis confirmed farmers' assessment of degradation status, with the $\mathrm{CH} 1$ site less degraded than the $\mathrm{CH} 2$ site. Organic $\mathrm{C}$ was lower by $44 \%$ and total $\mathrm{N}$ by $29 \%$ at $\mathrm{CH}$ 2. Depletion of cations and nutrients was much stronger and soil microbial biomass and soil enzyme activities were significantly lower at $\mathrm{CH} 2$.

Maize grain yields proved to be general indicators of soil fertility and crop performance. The yields of the control reflected productivity potential of soils and as such farmers' yields in the study area. Without fertilizer input, grain yield, total above ground biomass production and nutrient uptake were significantly lower at both sites. Grain yields were $0.6 \mathrm{t} \mathrm{ha}^{-1}$ at $\mathrm{CH} 2$ and $1.2 \mathrm{t} \mathrm{ha}^{-1}$ at $\mathrm{CH} \mathrm{1,} \mathrm{on} \mathrm{the} \mathrm{average} \mathrm{across} \mathrm{seasons.} \mathrm{The} \mathrm{difference} \mathrm{in}$ productivity of the control plots was attributed to lower nutrient release from SOM.

The major constraint for maize production was low inherent $\mathrm{N}$ and $\mathrm{P}$ content of soils. Fertilizer use could compensate for the low soil productivity. Under well managed conditions grain yield increased up to $4-5 \mathrm{tha}^{-1}$ upon $100 \mathrm{~kg} \mathrm{~N} \mathrm{ha}^{-1}, 60 \mathrm{~kg} \mathrm{P} \mathrm{ha}^{-1}, 60 \mathrm{~kg} \mathrm{~K}$ $\mathrm{ha}^{-1}$ and $25 \mathrm{~kg} \mathrm{Mg} \mathrm{ha}^{-1}$ on the average across sites. With combined mineral and organic fertilizer (All org) grain yields ranged between 4.1 and $5.3 \mathrm{t} \mathrm{ha}^{-1}$ over the years and across sites. In treatment (All), grain yield declined from 4.9 to $3.8 \mathrm{t} \mathrm{ha}^{-1}$ over three cropping seasons at $\mathrm{CH} 2$ whereas it remained on a high level of 4.0 to $4.1 \mathrm{t} \mathrm{ha}^{-1}$ at $\mathrm{CH} 1$. A total dry matter production of $6-10 \mathrm{t} \mathrm{ha}^{-1}$ involves an uptake by the maize crop of $80-130 \mathrm{~kg} \mathrm{~N} \mathrm{ha}^{-1}, 20-25 \mathrm{~kg} \mathrm{P} \mathrm{ha}^{-1}$ and $100-200 \mathrm{~kg} \mathrm{~K} \mathrm{ha}^{-1}$. Of these totals, about $50-90 \mathrm{~kg} \mathrm{~N} \mathrm{ha}^{-1}, 10-20 \mathrm{~kg} \mathrm{P} \mathrm{ha}{ }^{-1}$ and $30-60 \mathrm{~kg} \mathrm{~K} \mathrm{ha}^{-1}$ was in the grain. The remainder could have been returned to the soil in crop residues. With crop residues restitution high $\mathrm{K}$ removal could be minimized but also other nutrient losses from the system would be lowered. The potential benefit of the nutrients stored in crop residues to the soil can be estimated from straw data $\left(20-30 \mathrm{~kg} \mathrm{~N} \mathrm{ha}^{-1}, 2-3 \mathrm{~kg} \mathrm{P} \mathrm{ha}^{-1}\right.$ and $50-120 \mathrm{~kg} \mathrm{~K} \mathrm{ha}^{-1}$ ). 
At both sites, three years of maize cropping led to strong soil acidification. The decline in soil $\mathrm{pH}$ was lowest without mineral $\mathrm{N}$ supply. The main cause for acidification was the annual application of urea. There was also a slight decrease without mineral $\mathrm{N}$ fertilizer showing that maize cultivation enhanced acidity through SOM mineralization and cation removal, even at low yield levels. The decline was stronger at the degraded site. A decreasing soil $\mathrm{pH}$ indicates low buffer capacity and cation availability. The contribution of SOM to CEC decreases as a consequence of the variable charge nature of SOM exchange capacity.

Organic $\mathrm{C}$, total $\mathrm{N}$ and organic $\mathrm{P}$ levels fluctuated slightly across years but there were no treatment effects. Available $\mathrm{P}$ in the soils increased strongly due to yearly $\mathrm{P}$ application. In the control and (-P) plots available P remained unchanged. At the degraded $\mathrm{CH} 2$ site, the decrease in base saturation was much stronger and CEC remained lower throughout the experimental time for all treatments.

Soil organic matter was the major source of available nutrients. This was reflected by high correlations of SOM with CEC and soil nutrients. Across years, the use of cotton seed waste increased CEC in both soils. With a balanced mineral fertilization the status of CEC at the non-degraded $\mathrm{CH} 1$ site was maintained or even improved at the degraded $\mathrm{CH} 2$ site. These effects might be attributed to higher plant biomass residues in the fertilized plots.

Exchangeable $\mathrm{K}$ in soil increased due to $\mathrm{K}$ fertilization, however, it decreased without $\mathrm{K}$ input showing that the soils were susceptible to $\mathrm{K}$ degradation. Exchangeable $\mathrm{Ca}$ declined over the years without differences between treatments at both sites. Annual Mg application increased exchangeable $\mathrm{Mg}$ content.

Microbiological soil properties varied widely with sampling date and partly with treatment. All parameters distinguished between sites with generally lower microbial biomass and enzyme activities but, also lower seasonal variation at the degraded $\mathrm{CH} 2$ site. Microbial biomass was more sensitive to changes in management than organic $\mathrm{C}$ and total $\mathrm{N}$.

The incorporation of organic materials and better plant growth due to mineral fertilizer raised the biomass $\mathrm{C}$ level at the degraded $\mathrm{CH} 2$ site. Alkaline phosphatase and protease activity were less sensitive to fertilizer management effects than acid phosphatase and B-glucosidase activity. Fertilizer application increased soil enzyme activities from year to year. This effect was stronger at the degraded $\mathrm{CH} 2$ site. Partly, treatment effects were 
already visible in the second cropping season. The fertilizer effects were attributed to higher crop yields and higher amounts of crop residues left in the soil, which increased available substrate for microbial biomass and enzyme activities.

At the beginning of the experiments the two sites had different $\mathrm{NH}_{4}{ }^{+}$and $\mathrm{NO}_{3}{ }^{-}$proportions in the topsoil $(0-30 \mathrm{~cm})$. The major fraction of mineral $\mathrm{N}$ was $\mathrm{NH}_{4}{ }^{+}$at the non-degraded $\mathrm{CH} 1$ site and $\mathrm{NO}_{3}{ }^{-}$at the degraded $\mathrm{CH} 2$ site. Initial $\mathrm{N}_{\text {min }}$ content was lower at $\mathrm{CH} 2$ (24 $\left.\mathrm{kg} \mathrm{N} \mathrm{ha}^{-1}\right)$ as compared to the non-degraded $\mathrm{CH} 1$ site $\left(37 \mathrm{~kg} \mathrm{~N} \mathrm{ha}^{-1}\right)$. After applying fertilizers, in the first year the dominant form of mineral $\mathrm{N}$ shifted from $\mathrm{NH}_{4}-\mathrm{N}$ to $\mathrm{NO}_{3}-\mathrm{N}$ at $\mathrm{CH}$ 1. In 1994 and 1995 the largest fraction of mineral $\mathrm{N}$ was $\mathrm{NO}_{3}-\mathrm{N}$ in both soils. In the second and third season levels of $\mathrm{N}_{\min }$ closely followed $\mathrm{NO}_{3}{ }^{-}$levels in the soil.

In the third season the $\mathrm{NO}_{3}{ }^{-}$and $\mathrm{N}_{\text {min }}$ peaks upon fertilizer application indicated a good retention of the fertilizer- $\mathrm{N}$ in the soil profile. Mineral $\mathrm{N}$ supply increased soil $\mathrm{N}_{\min }$ content significantly as compared to the control and the (-N) treatment in the top soil. The subsequent decline of $\mathrm{N}_{\min }$ in the top soil was well reflected by increasing $\mathrm{N}_{\min }$ in the deeper soil horizons $\left(30-60 \mathrm{~cm}, 60-90 \mathrm{~cm}\right.$ ). The increasing $\mathrm{N}_{\min }$ content in the deeper soil layers was attributed to leaching of $\mathrm{NO}_{3}{ }^{-}$. Without $\mathrm{N}$ input, only small fluctuations of $\mathrm{N}_{\text {min }}$ could be detected in the deeper soil horizons. Across the soil profile $(0-90 \mathrm{~cm})$ moderate $\mathrm{N}_{\min }$ contents of $26-66 \mathrm{~kg} \mathrm{~N} \mathrm{ha}^{-1}$ were found in the (-N) treatment and in the control plots at $\mathrm{CH} 2$ indicating that substantial amounts of soil organic $\mathrm{N}$ were mineralized under maize during the growth period.

Preseason soil $\mathrm{NH}_{4}{ }^{+}, \mathrm{NO}_{3}{ }^{-}$and $\mathrm{N}_{\text {min }}$ at maize planting significantly correlated with grain yield and $\mathrm{N}$ uptake. Yield and $\mathrm{N}$ uptake was better related to $\mathrm{NO}_{3}{ }^{-}$than to $\mathrm{NH}_{4}{ }^{+}$. From the $\mathrm{N}_{\text {min }}$-balance it was concluded that the degraded $\mathrm{CH} 2$ soil was more susceptible to $\mathrm{N}$ losses from the system, whether fertilizer was applied or not. Maize growth and $\mathrm{N}$ uptake were lower and SMB, soil enzyme activities and $\mathrm{N}$ immobilization were reduced in the control of $\mathrm{CH}$ 2. Therefore, mineral $\mathrm{N}$ which was mineralized from the organic $\mathrm{N}$ during the early cropping season partly could not be used or stored and was lost from the system.

The total amount of mineralized $\mathrm{N}$ after aerobic incubation was dominated by net nitrification. Preseason cumulative mineral $\mathrm{N}$ in June 1995 was higher at the degraded $\mathrm{CH} 2$ site and tended to be lowest in the control plots. The average values across treatments ranged from 109 to $155 \mathrm{~kg} \mathrm{~N} \mathrm{ha}^{-1}$ for $\mathrm{CH} 1$ and $\mathrm{CH} 2$, respectively. 
The cumulative mineral $\mathrm{N}$ in soil accounted for about 3 to $12 \%$ of the total $\mathrm{N}$, being highest at $\mathrm{CH} 2$ (9 to $12 \%$ ) and lowest at $\mathrm{CH} 1$ soil (3 to $5 \%$ ). These observations indicate that at the beginning of the third season in the degraded $\mathrm{CH} 2$ soil a higher proportion of the stable organic $\mathrm{N}$ pool was getting mineralized.

By using the nonlinear regression procedure a first-order model was fit to the data. $\mathrm{N}_{0}$ represents a pool of readily-mineralizable $\mathrm{N}$ in soil which reflect the impact of soil type or management. The model produced generally good predictions of cumulative mineral $\mathrm{N}$ for all treatments and was giving an accurate estimation of the labile $\mathrm{N}$ pool in each of the two soils. Average preseason $\mathrm{N}_{0}$ was $136 \mathrm{~kg} \mathrm{~N} \mathrm{ha}^{-1}$ at $\mathrm{CH} 1$ and $167 \mathrm{~kg} \mathrm{~N} \mathrm{ha}^{-1}$ in the degraded $\mathrm{CH} 2$ field. However, no relationships could be found between maize grain yield and $\mathrm{N}$ uptake with $\mathrm{N}_{0}$ at both locations.

Potentially mineralizable $\mathrm{N}$ after anaerobic incubation (pot- $\mathrm{N}_{\min }$ ) varied among locations, soil depths, sampling time and treatments. On average, pot- $\mathrm{N}_{\min }$ ranged between 14 and $16 \mathrm{~kg} \mathrm{~N} \mathrm{ha}^{-1}$ at $\mathrm{CH} 1$ and between 13 and $14 \mathrm{~kg} \mathrm{~N} \mathrm{ha}^{-1}$ at $\mathrm{CH} 2$ in the top layer $(0-30 \mathrm{~cm})$. Potentially mineralizable $\mathrm{N}$ was highest after mineral fertilizer plus cotton seed waste application (All org) followed by complete mineral (All) and organic (org) fertilizer application at both sites and sampling dates throughout the profile. In the $(-\mathrm{N})$ treatment and the control, pot- $\mathrm{N}_{\min }$ was significantly lower. In contrast to $\mathrm{N}_{0}$, which was estimated after aerobic incubation, significant correlations were found between grain yield and $\mathrm{N}$ uptake with the preseason pot- $\mathrm{N}_{\min }$ from soil samples taken in June 1995 at both locations. The relationships obtained at $\mathrm{CH} 2$ site were much stronger, revealing that maize production and $\mathrm{N}$ uptake was more depended on $\mathrm{N}$ supply due to $\mathrm{N}$ mineralization from the labile soil organic $\mathrm{N}$ pool, in the $\mathrm{CH} 2$ than in the non-degraded $\mathrm{CH} 1$ soil. Predictability of maize grain yield increased when the whole soil profile was considered in the calculation.

Soil parameters were multicolinear and they were all considered of primary importance for soil quality. Principal component analysis (PCA) was used to reduce the number of variables and to detect an interpretable structure in the data set. The principal components reflected soil processes that played a significant role in explaining the variance in the data set and were related to soil quality. 
At first, PCA was applied on initial soil data to asses site history and to identify the major soil processes. As the main soil processes, SOM-, SMB-, and N-dynamics were identified. The non-degraded $\mathrm{CH} 1$ site was characterized by higher SOM- and N-dynamics as compared to the degraded $\mathrm{CH} 2$ site, whereas SMB-dynamics did not differentiate between sites. By inclusion of maize grain yield into the initial data set of the control plots, higher grain yield at the non-degraded $\mathrm{CH} 1$ site in the first season could be attributed to higher nutrient supply and higher mineralization of SOM due to higher soil enzyme activities.

Initial differences in soil quality parameters were attributed to different management or land-use intensity during the past years, causing a decrease in SOM content and nutrient depletion. From the initial soil characteristics, it was apparent that inadequate land use systems on the subsistence level cannot maintain SOM and nutrient levels and are therefore responsible for severe soil degradation in the savanna agroecosystems. Maize cropping without fertilizer input was depleting the SOM nutrient reserves and thus contributing to overall soil degradation, even at low yield levels.

At the beginning of the third season, PCA indicated similar soil processes as those identified at the initial stage (SOM-related nutrient dynamics, SMB-dynamics and N-dynamics). Soil quality was mainly determined by SOM content and SOM-related nutrient cycling processes. Changes in soil quality and soil degradation were attributed to decreasing soil nutrient content $(\mathrm{K}, \mathrm{Mg}, \mathrm{S}, \mathrm{Zn})$ and at the same time to fundamental degradation of the stable SOM pool and microbiological mediated soil processes. The main difference between the two sites was much lower SOM-related nutrient dynamics at $\mathrm{CH} 2$ indicating lower nutrient release from SOM and a degradation of the stable SOM pool, even with high mineral and organic fertilizer input. SOM-dynamics clearly differentiated between sites however, these did not change due to different inputs. However, it may be possible that soil microorganisms might be limited also by available $\mathrm{P}$ in soil. Although, $\mathrm{P}$ was identified as the second most limiting nutrient for maize production, the (-P) treatment was not included into the PCA because mineral $\mathrm{N}$ and $\mathrm{N}$ mineralization potential were not determined in these plots due to limited analytical capacity.

Fertilizer inputs were capable to compensate for nutrient limitations, especially for N. Only labile nutrient pools improved upon mineral fertilizer application. Additional cotton seed waste further stimulated these soil processes and contributed to improved nutrient supply. 
Parameter describing $\mathrm{N}$-dynamics revealed to be most strongly affected by short-term changes in the soil due to changing mineral and organic fertilizer inputs. Soil enzyme activities and SMB-dynamics could be stimulated with external mineral and organic inputs.

Cultivation of soils, besides affecting soil chemistry and structure, also affected soil biology. The main effects must be attributed to a decrease in SOM, soil nutrients and a decrease in biochemical soil processes that are related to mineralization.

SOM-dynamics are more stable without much sensitivity to short-term changes due to different input management. The main variables contributing to better SOM-dynamics at the non-degraded $\mathrm{CH} 1$ site were higher $\mathrm{K}, \mathrm{Mg}, \mathrm{Zn}, \mathrm{S}, \mathrm{Ca}$, total $\mathrm{N}$ and organic $\mathrm{P}$ content together with a higher soil $\mathrm{pH}$, and higher acid and alkaline phosphatase, $\beta$-glucosidase and protease activity.

The selected microbial properties such as SMB, acid phosphatase, protease and B-glucosidase activity were closely related to SOM and nutrient cycling processes. Mineral $\mathrm{N}\left(\mathrm{NH}_{4}{ }^{+}, \mathrm{NO}_{3}{ }^{-}\right)$and potential $\mathrm{N}$ mineralization were more sensitive indices than total $\mathrm{N}$ content. Therefore, it is suggested to include sensitive microbial parameters, mineral $\mathrm{N}$ and $\mathrm{N}$ mineralization indices in data sets to describe soil fertility changes due to different management practices and to asses soil quality.

The results showed that savanna soils are very poor and that without mineral fertilizer or organic amendments, these soils have a reduced potential to accomplish the important soil function of nutrient supply. Mineral fertilizer combined with cotton seed waste improved the nutrient status of the soil, biological and biochemical characteristics and improved maize yield and nutrient uptake and thus, appear to be the best way of fertilization. However, crop yields and soil fertility may be maintained or improved in the long run, only by a integrated approach of crop residue restitution, fallowing, or green manuring together with application of inorganic and organic fertilizers, organic manures or mulches. 


\section{$8 \quad$ Zusammenfassung}

Der Rückgang der Nahrungsproduktion in Nordghana ist in erster Linie auf nicht angepaßte Anbaumethoden und auf eine damit einhergehende Abnahme der Bodenfruchtbarkeit auf den Anbauflächen der kleinbäuerlichen Betriebe zurückzuführen. Nährstoffverluste durch Export der Ernteprodukte, Auswaschung und Erosion sowie drastische Verkürzungen der Brachezeiten aufgrund von Landknappheit führten zu Bodendegradation. Der Einsatz von Mineraldünger ist wegen hoher Düngerpreise sehr gering und organische Dünger stehen oft nicht in ausreichendem Maße zur Verfügung.

Als ein dynamisches System haben Böden eine zentrale Bedeutung für die Funktion des Ökosystems. Für eine präzisere Definition der Begriffe Bodenfruchtbarkeit und Bodenqualität ist es notwendig, das Zusammenwirken von physikalischen, chemischen und mikrobiologischen Bodeneigenschaften und ihre Wechselbeziehungen $\mathrm{zu}$ untersuchen. Bei der Suche nach einer verläßlichen Methode zur Bestimmung der Bodenqualität müssen jene Bodenparameter ausgewählt werden, die sensitiv gegenüber unterschiedlichen Managementpraktiken sind. Zur Abschätzung diverser Managementeffekte auf Bodenfunktionen- und qualität werden diese Bodeneigenschaften in einem Index integriert und in Beziehung zu nachhaltiger landwirtschaftlicher Produktion gesetzt.

Die vorliegende Forschungsarbeit wurde am Savanna Agricultural Research Institute (SARI) in Nordghana durchgeführt. Der wissenschaftliche Ansatz war, mittels der Nutzungsgeschichte ein degradiertes und ein nicht degradiertes Bauernfeld $\mathrm{zu}$ finden. Diese kontrastierenden Flächen dienten als Grundlage für Düngungsversuche und zur Eichung der angewandten mikrobiologischen Methoden. Im Zeitraum von 1993 bis 1995 wurden jeweils in der Regenzeit zwischen Juni und Oktober Düngungsversuche mit Mais auf beiden Standorten durchgeführt. In Zusammenhang mit diesem Ansatz wurden neben chemischen Bodenparametern wie $\mathrm{pH}$, organisches $\mathrm{C}$, Gesamt-N, organisches und verfügbares $\mathrm{P}$, Basensättigung, effektive Austauschkapazität, austauschbare Kationen $(\mathrm{K}, \mathrm{Ca}, \mathrm{Mg}, \mathrm{Mn}, \mathrm{Zn})$, mineralischer $\mathrm{N}\left(\mathrm{NH}_{4}{ }^{+}, \mathrm{NO}_{3}{ }^{-}\right)$und mikrobiologische Parameter wie die mikrobielle Biomasse, Bodenenzymaktivitäten sowie Indizes für die potentielle $\mathrm{N}-$ Mineralisierung (aerobe und anaerobe Inkubation) bestimmt. 
Das Ziel der Forschung war, ausgewählte mikrobiologische Parameter als Bioindikatoren für die Bodenqualität zu prüfen. Hierzu wurden neben der mikrobiellen Biomasse die Potentiale von ausgewählten Bodenenzymen des C-, N-, und P-Kreislaufs (ß-Glucosidase, Protease, alkalische und saure Phosphatase) untersucht.

Es wurden zwei identische Versuche angelegt. Im ersten Jahr wurden $100 \mathrm{~kg} \mathrm{~N} \mathrm{ha}^{-1}$, $60 \mathrm{~kg} \mathrm{P}$ und $\mathrm{K} \mathrm{ha}^{-1}, 80 \mathrm{~kg} \mathrm{Ca} \mathrm{ha}{ }^{-1}, 20 \mathrm{~kg} \mathrm{Mg} \mathrm{ha}^{-1}, 25 \mathrm{~kg} \mathrm{~S} \mathrm{ha}^{-1}, 10 \mathrm{~kg} \mathrm{Zn} \mathrm{ha}{ }^{-1}$ und $400 \mathrm{~g} \mathrm{Mo} \mathrm{ha}^{-1}$ gedüngt. In der komplett mineralisch gedüngten Variante (All) wurden alle Nährstoffe in anorganischer Form ausgebracht. Um zu prüfen, welcher der gedüngten Nährstoffe im Boden im Mangel vorliegt, wurden in den Behandlungen (-N), (-P), (-K), (-Ca), (-Mg), (-S), (-Mo) alle Nährstoffe gedüngt, nur der jeweils zu untersuchende Nährstoff wurde weggelassen. In der Behandlung (All org) wurde neben der kompletten mineralischen Düngung aller Nährstoffe noch zusätzlich Baumwollsaatabfall als organischer Dünger verabreicht $\left(2 \mathrm{t} \mathrm{ha}^{-1}\right)$. Das Versuchsdesign wurde im zweiten und dritten Versuchsjahr aufgrund der Ergebnisse vom ersten Jahr geändert. Da kein Behandlungseffekt zu erkennen war, wurde (-Ca) in die Behandlung organische Düngung (org) geändert, um die alleinige Wirkung von Baumwollsaatabfall zu testen. Die Zn-Menge wurde von $10 \mathrm{~kg} \mathrm{ha}^{-1}$ auf $5 \mathrm{~kg} \mathrm{ha}^{-1}$ reduziert. Da Mo keine im ersten Jahr keine Wirkung zeigte und $\mathrm{Zn}$ als ertragsbegrenzender Faktor nach einer P Düngung auf manchen Flächen eine bedeutende Rolle spielen kann wurde (-Mo) zu (-Mo/-Zn) erweitert.

Der Oberboden der Versuchsböden war mäßig sauer. Die Basensättigung war hoch, mit Ca und $\mathrm{Mg}$ als dominierende Kationen. Im Vergleich der Standorte waren die effektive Austauschkapazität (KAK) und die Gehalte an organischem C, Gesamt-N, austauschbaren Kationen, Sulfat-S, und verfügbarem P (Bray-I) am Standort CH 2 sehr niedrig. Mit Ausnahme der Basensättigung, die auf beiden Flächen nicht unterschiedlich war und des $\mathrm{NO}_{3}{ }^{-}$Gehaltes im Boden, welcher am Standort $\mathrm{CH} 1$ niedriger war, erwiesen sich alle untersuchten Bodenparameter am Standort $\mathrm{CH} 2$ signifikant niedriger als am Standort CH 1. Die Bodenuntersuchungen zur Bestimmung des Ausgangszustandes beider Standorte bestätigten somit die Einschätzung der Bauern, daß Standort $\mathrm{CH} 1$ weniger und $\mathrm{CH} 2$ stärker degradiert war. Dies war besonders deutlich für Gehalte an organischem $\mathrm{C}$ und Gesamt-N, die am degradierten Standort um 44 \% bzw. $29 \%$ niedriger waren. Auch wies der degradierte Standort eine stärkere Kationen- und Nährstoffverarmung, eine niedrigere mikrobielle Biomasse und geringere Enzymaktivität im Boden auf. 
Die Maiserträge (Zea mays L.) dienten als Indikator für die pflanzenverfügbaren Nährstoffe im Boden. Das Ertragsniveau in der Kontrolle reflektierte die Bodenproduktivität und entsprach dem der Kleinbauern. Ohne Düngung lag der Ertrag bei $0.6 \mathrm{t} \mathrm{ha}^{-1}(\mathrm{CH} 2)$ und $1.2 \mathrm{t} \mathrm{ha}^{-1}(\mathrm{CH}$ 1) im Durchschnitt über drei Vegetationsperioden. $\mathrm{N}$ und $\mathrm{P}$ waren die ertragsbegrenzenden Nährstoffe. Durch eine kombinierte mineralische und organische Düngung (All org) konnte das Etragsniveau auf 4.1 - $5.3 \mathrm{t} \mathrm{ha}^{-1}$ angehoben werden. Mit mineralischer Düngung (All) lag das Ertragsniveau am nicht degradierten Standort $\left(\mathrm{CH}\right.$ 1) über drei Anbaujahre bei 4.0 - $4.1 \mathrm{t} \mathrm{ha}^{-1}$. Am degradierten Standort $(\mathrm{CH} 2)$ gingen die Erträge von $4.9 \mathrm{t} \mathrm{ha}^{-1}$ im ersten Jahr auf $3.8 \mathrm{t} \mathrm{ha}^{-1}$ im dritten Anbaujahr zurück.

Eine oberirdische Maisbiomasseproduktion von 6 - $10 \mathrm{t} \mathrm{ha}^{-1}$ geht mit einer Nährstoffaufnahme von 80 - $130 \mathrm{~kg} \mathrm{~N} \mathrm{ha}^{-1}, 20-25 \mathrm{~kg} \mathrm{P} \mathrm{ha}^{-1}$ und $100-200 \mathrm{~kg} \mathrm{~K}^{-1}$ einher. Von diesen Nährstoffen finden sich $50-90 \mathrm{~kg} \mathrm{~N} \mathrm{ha}^{-1}, 10-20 \mathrm{~kg} \mathrm{P} \mathrm{ha}^{-1}$ und $30-60 \mathrm{~kg} \mathrm{~K} \mathrm{ha}^{-1} \mathrm{im}$ Korn wieder. Der Rest konnte als Ernterückstände wieder dem Boden zugeführt werden. Die Mengen an Nährstoffen in den Ernterückständen konnten anhand der Nährstoffaufnah men im Stroh geschätzt werden (20 - $30 \mathrm{~kg} \mathrm{~N} \mathrm{ha}^{-1}, 2-3 \mathrm{~kg} \mathrm{P} \mathrm{ha}{ }^{-1}$ und $\left.50-120 \mathrm{~kg} \mathrm{~K} \mathrm{ha}^{-1}\right)$.

Der Maisanbau führte zu einer starken Versauerung im Oberboden. Ohne Harnstoffdüngung war der Rückgang des pH-Wertes am geringsten. Die Kontrolle zeigte jedoch, daß Maisanbau ohne Harnstoffdüngung ebenfalls eine Versauerung des Boden bewirkte. Gleichzeitig war ein starker Rückgang der austauschbaren Kationen zu verzeichnen. Die Versauerung war auf den Abbau von organischer Substanz und den Entzug von Kationen zurückzuführen. Der Rückgang des pH-Wertes war am degradierten Standort stärker.

Mit der Düngung von N, P, K und Mg stiegen die Gehalte an mineralischem N, verfügbarem P, austauschbaren Kationen (K, Mg und $\mathrm{Zn}$ ) sowie die KAK im Boden deutlich an. Ohne P-Düngung blieben die P-Konzentrationen im Boden unverändert. Die Bilanz für das austauschbare $\mathrm{K}$ im Boden war ohne K-Gaben negativ. Im Versuchsverlauf kam es am Standort CH 2 zu einem starken Rückgang der Basensättigung. Das austauschbare Ca im Boden ging von 1993 bis 1995 in allen Behandlungen und an beiden Standorten zurück.

Die Gehalte an organischem C, Gesamt-N und organischem P im Boden schwankten im Versuchszeitraum von 1993 bis 1995 geringfügig, es wurden jedoch keine behandlungsbedingten Veränderungen festgestellt. Die organische Substanz war eng mit der Kationenaustauschkapazität (KAK) sowie mit den Nährstoffen im Boden korreliert. Nach der organischen Düngung mit Baumwollsaatabfällen war die KAK deutlich erhöht. 
Ohne Düngung war die KAK im Versuchsverlauf rückläufig. Mit einer ausgeglichenen mineralischen Düngung konnte der Status der KAK im nicht degradierten Boden $(\mathrm{CH} 1)$ erhalten, im degradierten Boden $(\mathrm{CH} 2)$ sogar verbessert werden. Dieser Effekt wurde auf die größeren Mengen an Ernterückständen in den gedüngten Varianten zurückgeführt.

Anhand der untersuchten mikrobiologischen Bodenparameter konnten die Standorte unterschieden werden. Die mikrobiologischen Parameter schwankten deutlich zwischen den Probenahmezeitpunkten. Die Größe der mikrobiellen Biomasse und die Enzymaktivitäten waren vom Standort (Boden), C-"input” und Umweltfaktoren abhängig. Am degradierten Standort CH 2 waren die mikrobielle Biomasse und die Enzymaktivitäten niedriger. Auch die saisonalen Schwankungen waren hier deutlich geringer.

Begrenzender Faktor für das Wachstum der Mikroorganismen war die Nährstoffverfügbarkeit. Die alkalische Phosphatase- und die Proteaseaktivität waren gegenüber unterschiedlichem Düngermanagement weniger sensibel als die saure Phosphatase- und B-Glucosidaseaktivität. Im allgemeinen bewirkte die Düngung höhere Enzymaktivitäten im Versuchsverlauf von 1993 - 1995. Teilweise waren Behandlungswirkungen schon am Ende der zweiten Vegetationsperiode sichtbar. Die positiven Auswirkungen einer Düngung auf die mikrobiologischen Parameter wurden in erster Linie auf die höheren Erträge zurückgeführt, die in diesen Varianten erzielt wurden. Diese bewirkten größere Mengen an Ernterückständen im Boden, und damit mehr Substrat für das Wachstum der Mikroorganismen.

$\mathrm{Zu}$ Versuchsbeginn waren die Gehalte an $\mathrm{NH}_{4}{ }^{+}$und $\mathrm{NO}_{3}{ }^{-}$im Oberboden der beiden Stand- orte signifikant verschieden. Am Standort $\mathrm{CH} 1$ war $\mathrm{NH}_{4}{ }^{+}$, am Standort $\mathrm{CH} 2$ war $\mathrm{NO}_{3}{ }^{-}$der dominierende Anteil am gesamten mineralischen $\mathrm{N}\left(\mathrm{N}_{\min }\right)$ im Boden. $\mathrm{CH} 2$ wies insgesamt geringere Gehalte an $\mathrm{N}_{\min }\left(24 \mathrm{~kg} \mathrm{~N} \mathrm{ha}^{-1}\right)$ auf als $\mathrm{CH} 1\left(37 \mathrm{~kg} \mathrm{~N} \mathrm{ha}^{-1}\right)$. Nach der Düngung war $\mathrm{NO}_{3}-\mathrm{N}$ an beiden Standorten die bestimmende Form des mineralischen $\mathrm{N}$ im Boden. Im zweiten und dritten Versuchsjahr stellte $\mathrm{NO}_{3}-\mathrm{N}$ in beiden Böden die größte Fraktion des mineralischen $\mathrm{N}$ dar und der Verlauf des $\mathrm{N}_{\text {min }}$ wurde vom $\mathrm{NO}_{3}{ }^{-}$-Gehalt im Boden bestimmt. Die $\mathrm{NO}_{3}{ }^{-}$- und $\mathrm{N}_{\text {min }}$-Werte im Bodenprofil spiegeln deutlich die N-Düngung wider. Die Harnstoffdüngung bewirkte eine signifikante Erhöhung der $\mathrm{N}_{\text {min }}$-Gehalte im Boden. Der Maiskornertrag und die N-Aufnahme in der oberirdischen Maisbiomasse waren eng mit den Gehalten von $\mathrm{NH}_{4}{ }^{+}$und $\mathrm{NO}_{3}{ }^{-}$im Boden korreliert. Damit erwiesen sich die vor der Aussaat gemessenen $\mathrm{NH}_{4}{ }^{+}$- und $\mathrm{NO}_{3}{ }^{-}$-Konzentrationen im Boden als geeignete Parameter, um den Maisertrag abzuschätzen. 
Anhand der $\mathrm{N}_{\text {min }}$-Bilanz konnte die Unterschiedlichkeit der beiden Standorte hinsichtlich ihrer N-Versorgung und N-Ausnutzung deutlich gemacht werden. Am nicht degradierten Standort $\mathrm{CH} 1$ war die $\mathrm{N}_{\min }$-Bilanz für alle Behandlungen positiv. Die höchsten $\mathrm{N}_{\text {min }}$-Gewinne im System Boden-Pflanze wurden durch eine kombinierte mineralische und organische Düngung erreicht. Selbst in der Kontrolle und in der (-N) Variante war die $\mathrm{N}_{\text {min }}$-Bilanz positiv, was auf $\mathrm{N}$-Einträge durch Niederschläge zurückzuführen ist. Am degradierten Standort CH 2 kam es in allen Behandlungen zu Verlusten an mineralischem $\mathrm{N}$, die in der Kontrolle und bei (-N) am höchsten waren. Daraus leitet sich ab, daß der degradierte Standort mit niedrigeren Erträgen und N-Aufnahmen sowie mit niedrigeren mikrobiologischen Aktivitäten weniger mineralischen $\mathrm{N}$ im System Boden-Pflanze speichern kann.

Das Ausmaß der N-Mineralisierung nach aerober Inkubation wurde von der Nitrifikation bestimmt. Die potentielle N-Mineralisierung zu Beginn der dritten Saison (Juni 1995) war am Standort $\mathrm{CH} 2$ höher, mit der Tendenz zu niedrigerer N-Mineralisierung in der Kontrolle. Die durchschnittlichen Mengen des angehäuften $N_{\min }$ waren 109 und $155 \mathrm{~kg} \mathrm{~N}$ ha $^{-1}$ für $\mathrm{CH} 1$ und $\mathrm{CH}$ 2. Diese Mengen entsprachen 3 - $12 \%$ des Gesamt-N im Boden. Im degradierten Feld ( $\mathrm{CH}$ 2) war der Anteil mit 9 - $12 \%$ deutlich höher als im nicht degradierten Feld (CH 1) mit 3 - 5 \%. Damit wurde in $\mathrm{CH} 2$ zu Beginn der dritten Saison ein höherer Anteil des organischen N-Pools im Boden mineralisiert.

Mit Hilfe einer nicht linaren Regressionsgleichung, wurde ein Model erster Ordnung an die $\mathrm{N}_{\text {min }}$-Daten nach aerober Inkubation angepaßt. Der geschätzte Parameter $\left(\mathrm{N}_{0}\right)$ repräsentiert den leicht mineralisierbaren N-Pool im Boden. Dieses Model beschreibt die potentielle $\mathrm{N}-$ Nachlieferung aus dem organischen N-Pool. Im Durchschnitt lag $\mathrm{N}_{0}$ bei $136 \mathrm{~kg} \mathrm{~N} \mathrm{ha}^{-1}$ in $\mathrm{CH} 1$ und bei $167 \mathrm{~kg} \mathrm{~N}^{-1}$ in $\mathrm{CH}$ 2. An beiden Standorten war $\mathrm{N}_{0}$ weder mit dem Maisertrag noch mit der N-Aufnahme korreliert.

Die Bestimmung des potentiell mineralisierbaren $\mathrm{N}$ (pot- $\mathrm{N}_{\min }$ ) nach anaerober Inkubation gilt als "biologischer Index" für die N-Verfügbarkeit im Boden. Pot- $\mathrm{N}_{\text {min }}$ war vom Standort, von der Probenahmetiefe, vom Probenahmezeitpunkt und von der Düngung abhängig. An beiden Standorten wirkte sich die Düngung positiv auf die Mengen des potentiell mineralisierbaren $\mathrm{N}$ aus. Dagegen war pot- $\mathrm{N}_{\min }$ ohne mineralische oder organische N-Düngung stets niedriger. In der Kontrolle war pot- $\mathrm{N}_{\min }$ jeweils am niedrigsten. Selbst in tieferen Bodenschichten wurden nach N-Düngung höhere Werte festgestellt. 
In den gedüngten Varianten wurde eine größere Maisbiomasse erzielt. Damit wurden auch größere Mengen an Wurzelresten in den tieferen Bodenschichten am Anfang der Vegetationsperiode mineralisiert. Zu Beginn der dritten Saison war pot- $\mathrm{N}_{\text {min }}$ im Oberboden $(0-30 \mathrm{~cm})$ von $\mathrm{CH} 2$ etwas höher als in $\mathrm{CH}$ 1. Dies stimmt mit den Ergebnissen nach aerober Inkubation überein und deutet auf einen verstärkten Abbau der organischen N-Reserven hin.

Im Gegensatz zu $\mathrm{N}_{0}$ war pot- $\mathrm{N}_{\text {min }}$ eng mit dem Maiskornertrag und der $\mathrm{N}$-Aufnahme in der oberirdischen Maisbiomasse korreliert. Am Standort CH 2 war die Maisproduktion stärker von der N-Nachlieferung aus dem organischen N-Pool abhängig als am Standort CH 1. Wurde neben Pot- $\mathrm{N}_{\min }$ auch $\mathrm{N}_{\min }$ im Boden in das Modell aufgenommen (Multiple Regression), konnte die Güte der Anpassung des Models verbessert werden. Damit war der Maisertrag bzw. die N-Aufnahme eine Funktion der potentiellen N-Nachlieferung (Pot- $\mathrm{N}_{\min }$ ) und der $\mathrm{N}_{\min }$-Gehalte im Boden zu Beginn der Vegetationszeit.

Die untersuchten Bodenparameter zeigten deutlich, daß eine Vielzahl von Einflußfaktoren bei der Beurteilung der Bodenqualität zu berücksichtigen sind. Alle Variablen standen in enger Beziehung mit der organischen Substanz des Bodens. Die verschiedenen chemischen und mikrobiologischen Variablen waren zusätzlich unterschiedlich stark miteinander korreliert. Durch die statistische Methode der Hauptkomponentenanalyse (PCA) war es möglich, die Vielzahl der Variablen zu testen und auf wenige, erklärungsrelevante Einflußfaktoren zu reduzieren.

Um die unterschiedliche Bodenqualität auf die Landnutzungsgeschichte der jeweiligen Standorte zurückzuführen, wurde eine PCA für die zu Versuchsbeginn gemessenen Bodenparameter durchgeführt. Es wurden drei Faktoren ermittelt, die für die Erklärung der Bodenqualität entscheidend waren. Der erste Faktor erklärte $56 \%$ der Varianz im Datensatz. Die bestimmenden Variablen des ersten Faktors wurden unter dem Sammelbegriff “Dynamik der organischen Substanz” zusammengefaßt, da die erklärenden Bodenparameter dem organischen Nährstoff-Pool zugeordnet werden und Variablen wie Boden-pH, $\mathrm{NH}_{4}-\mathrm{N}$, Protease-, Glucosidase-, alkalische und saure Phosphataseaktivität Indikatoren für die Nachlieferung von organisch gebundenen Nährstoffen durch Mineralisierung darstellen. Damit waren die Nährstoffumsetzungen aus der organischen Substanz die entscheidenden Prozesse im Boden, die für die ursprünglichen Unterschiede in der Bodenqualität verantwortlich waren. 
Der zweite Faktor wurde unter dem Begriff "Dynamik der mikrobiellen Biomasse" zusammengefaßt und erklärte $13 \%$, der dritte Faktor unter dem Sammelbegriff "N-Dynamik" erklärte $15 \%$ der Unterschiede.

Die Bodenqualität der Standorte zu Versuchsbeginn (Juni 1993) konnte hinsichtlich der “Dynamik der organischen Substanz" und der "N-Dynamik" eindeutig unterschieden werden. Der nicht degradierte Standort $(\mathrm{CH} 1)$ war mehrheitlich durch eine positive Ausprägung beider Faktoren gekennzeichnet, während der degradierte Standort ( $\mathrm{CH} 2)$ mehrheitlich durch negative Faktorwerte gekennzeichnet war. Es konnten $71 \%$ der ursprünglichen Unterschiede in der Bodenqualität durch Unterschiede in den Umsetzungen der organischen Substanz (56 \%) und in der N-Dynamik (15\%) erklärt werden. Ursache ist das unterschiedliche Landmanagement der Bauern in den zurückliegenden Jahren.

Unter Hinzunahme der Maiserträge für die ungedüngten Kontrollparzellen konnten aufgetretene Ertragsunterschiede direkt auf die Unterschiede in der Bodenqualität beider Standorte zurückgeführt werden. Darüberhinaus konnten neben den identifizierten Bodenprozessen auch die ertragsbestimmenden Bodenparameter sichtbar gemacht werden, die hinsichtlich der Maisproduktion ohne Düngung entscheidend sind. Am nicht degradierten Standort CH 1 waren die höheren Gehalte an organischer Substanz und die, von Enzymen im Boden gesteuerte Nährstoffnachlieferung aus dem organisch gebundenen Nährstoff-Pool, für die höheren Maisertäge verantwortlich. Im Gegensatz dazu war die N-Mineralisierung am degradierten Standort CH 2 entscheidend höher, was einen verstärkten Abbau der organisch gebundenen N-Reserven an diesem Standort belegt.

Um die Auswirkungen von zweijährigem Maisanbau und der unterschiedlichen Nährstoffbehandlungen auf die Bodenqualität zu prüfen, wurde eine PCA für die, zu Beginn der dritten Vegetationszeit, gemessenen Bodenparameter durchgeführt. Durch die Hinzunahme der Maiserträge sollten die Bodenparameter identifiziert werden, die im dritten Versuchsjahr für die Maisproduktion bei unterschiedlicher Düngung entscheidend waren. Der entscheidende Unterschied zur PCA von Juni 1993 war, daß sich zu Beginn der dritten Saison die organische Substanz als eigenständiger vierter Faktor herauskristallisierte.

Der erste Faktor "Dynamik der organischen Substanz" erklärte $47 \%$ der Varianz im Datensatz. Damit waren die Nährstoffumsetzungen aus der organischen Substanz auch in der dritten Vegetationsperiode die entscheidenden Prozesse im Boden, die für die Unterschiede in der Bodenqualität und der Maisproduktion verantwortlich waren. 
Der zweite Faktor (“N-Dynamik”) erklärte $15 \%$. Neben den Parametern der N-Dynamik war der Maisertrag diesem Faktor zugeordnet. Daraus folgt, daß die Maisproduktion in erster Linie eine Funktion der N-Versorgung war. Der dritte Faktor wurde unter dem Sammelbegriff “Dynamik der mikrobiellen Biomasse” zusammengefaßt und erklärte $9 \%$.

Die Bodenqualität der beiden Standorte und die Auswirkungen der verschiedenen Düngungsvarianten konnten hinsichtlich der "Dynamik der organischen Substanz" und der "N-Dynamik" eindeutig unterschieden werden. Die "Dynamik der organischen Substanz" wurde durch die Düngung nicht beeinflußt und war am nicht degradierten Standort ( $\mathrm{CH}$ 1) positiv und am degradierten Standort $(\mathrm{CH} 2)$ negativ ausgeprägt. Dagegen war die "N-Dynamik" an beiden Standorten von der Düngung abhängig. Ohne N-Düngung (-N) und in der Kontrolle war die "N-Dynamik" durch negative Faktorwerte gekennzeichnet, während mit organischer Düngung (org), kompletter mineralischer Düngung (All) und kombinierter organischer und mineralischer Düngung (All org) die N-Umsetzungen im Boden verbessert werden konnten.

Die Bodendegradierung am Standort CH 2 war in erster Linie eine Degradierung der Umsetzungen der organischen Substanz im Boden. Selbst mit hohem mineralischem und organischem Düngereinsatz konnte der Trend des Abbaus der organischen Nährstoffreserven an diesem Standort kurzfristig nicht rückgängig gemacht werden. Nur die labilen, leicht umsetzbaren Nährstoffpools des C- und N-Kreislaufs wurden kurzfristig durch mineralischen und organischen Düngereinsatz erhöht. Dies führte zwar zu höheren Maiserträgen, jedoch konnte die Bodenfruchtbarkeit dadurch nicht nachhaltig verbessert werden.

Für eine nachhaltige Erhöhung der Pflanzenerträge in der Guinea Savanne in Ghana und für die Erhaltung der Bodenfruchtbarkeit ist die Zufuhr von Nährstoffen notwendig. Um einen weiteren Rückgang der organischen Substanz und der Nährstoffreserven im Boden in Zukunft zu vermeiden, ist ein integriertes System der Pflanzenernährung notwendig. Dieser Ansatz integriert Möglichkeiten wie die Verwendung von mineralischen und organischen Düngern, die Nutzung von Ernterückständen und die Verbesserung der Brachesysteme mit krautigen Leguminosen als Bodendecker, Mulch und zur Gründüngung sowie die Einschaltung von Leguminosen oder Baumwolle in eine Fruchtfolge.

Es wird erwartet, daß ein integriertes System zur Pflanzenernährung unter den gegebenen Umständen positive Auswirkungen auf die Bodenqualität hat und die Bodenfruchtbarkeit erhalten kann. 


\section{$9 \quad$ References}

Abekoe, M. A., Tiessen, H. 1998. Fertilizer P transformations and P availability in hillslope soils of northern Ghana. Nutrient Cycling in Agroecosystems 52, 45 - 54.

Adams, M. A. 1992. Phosphatase activity and phosphorus fractions in Karri (Eucalyptus diversicolor F. Muell.) forest soils. Biol Fertil Soils 14, 200 - 204.

Albert, H. 1996. Farm household systems in northern Ghana and the problem of striga. Unpublished workshop paper 1996. Savanna Agricultural Research Institute (SARI).

Alef, K. 1991. Methodenhandbuch Bodenmikrobiologie. Ecomed Verlag, Landsberg/Lech, p 284.

Alef, K. 1995a. Nitrogen mineralization in soils. In: Alef, K. and Nannipieri, P. (eds). Methods in applied soil microbiology and biochemistry. Academic Press, 24-28 Oval Road, London, UK.

Alef, K., Nannipieri, P. 1995. B-Glucosidase activity. In: Alef, K. and Nannipieri, P. (eds). Methods in applied soil microbiology and biochemistry. Academic Press, 24-28 Oval Road, London, UK.

Alef, K., Nannipieri, P. 1995a. Protease activity. In: Alef, K. and Nannipieri, P. (eds). Methods in applied soil microbiology and biochemistry. Academic Press, 24-28 Oval Road, London NW1 7DX.

Anane-Sakyi, C. 1995. Potentials of legumes for crop yield and soil fertility improvement in the north-eastern savanna zone of Ghana. In: Proceedings of seminar on organic and sedentary agriculture, 1.-3. November, 1995 at the Science \& Technology Policy Research Institute (CSIR), Accra, Ghana.

Anderson, T. H., Domsch, K. H. 1989. Ratios of microbial biomass carbon to total organic carbon in arable soils. Soil Biol Biochem 21, 471 - 480.

Arshad, M. A., Coen, G. M. 1992. Characterization of soil quality: Physical and chemical criteria. Am J Alternative Agric 7, 25 - 31.

Asmar, F., Singh, T., Nielsen, G., Nielsen, N. E. 1995. Barley genotypes differ in activity of soluble extracellular phosphatase and depletion of organic phosphorus in the rhizosphere soil. Plant Soil 172, 117 - 122.

Ayanaba, A., Tuckwell, S. B., Jenckinson, D. S. 1976. The effects of clearing and cropping on the organic reserves and biomass of tropical forest soils. Soil Biol Biochem 8, 519 - 529.

Backhaus, K., Erichson, B., Plinke, W. and Weiber, R. 1996. Multivariate Analysemethoden, 8. Ausgabe, Springer Verlag, Berlin.

Badalucco, L., Kuikman, P. J., Nannipieri, P. 1996. Protease and deaminase activities in wheat rhizosphere and their relation to bacterial and protozoan populations. Biol Fertil Soils 23, 99 - 104.

Ball-Coelho, B., Salcedo, I. H., Tiessen, H., Stewart, J. W. B. 1993. Short- and long-term phosphorus dynamics in a fertilized Ultisol under sugarcane. Soil Sci Soc Am J 57, 1027 - 1034.

Barios E., Buresh, R. J., Sprent, I. J. 1996. Nitrogen mineralization in density fractions of soil organic matter from maize and legume cropping systems. Soil Biol Biochem 28 (10/11), 1459 - 1465.

Barios E., Kwesiga, F., Buresh, R. J., Sprent, I. J., Coe, R. 1998. Relating preseason soil nitrate to maize yield in tree legume-maize rotations. Soil Sci Soc Am J 62, 1604 - 1609.

Beck, M., Sanchez, P. A. 1994. Soil phosphorus fraction dynamics during 18 years of cultivation on a typic Paleudult. Soil Sci 34, 1424 - 1431. 
Beck, T. 1983. Die N-Mineralisierung von Böden im Laborversuch. Z Pflanzenernähr Bodenkd 146, 243 252.

Beck, T. 1984. Mikrobiologische und biochemische Charakterisierung landwirtschaftlich genutzter Böden. I. Die Ermittlung einer Bodenmikrobiologischen Kennzahl. Z Pflanzenernähr Bodenkd 147, 456 - 466.

Benedetti, A., Sebastiani, G. 1996. Determination of potentially mineralizable nitrogen in agricultural soils. Biol Fertil Soils 21, 114 - 120.

Beyer, L. 1995. Soil microbial biomass and organic matter composition in soils under cultivation. Biol Fertil Soils 21, 197 - 202.

Blagodatsky, S. A., Richter, O. 1998. Microbial growth in soil and nitrogen turnover: A theoretical model considering the activity state of microrganisms. Soil Biol Biochem 30 (13), 1743 - 1755.

Blake, G. R., Hartge, K. H. 1986. Bulk Density. In. Klute, A. (Hrsg): Methods of Soil Analysis. Madison, Wisconsin, USA: American Society of Agronomy \& Soil Science Society of America (Agronomy No. 9, pt $1,2^{\text {nd }}$ ed.), S. $363-375$.

Bohlool, B. B., Ladha, J. K., Garrity, D. P., George, T. 1992. Biological nitrogen fixation for sustainable agriculture: A perspective. Plant Soil 141, 1 - 12.

Bonmati, M. C., Ceccanti, B., Nannipieri, P. J. 1991. Spatial variability of phosphatase, urease, protease, organic carbon and total nitrogen in soil. Soil Biol Biochem 23 (4), 391 - 396.

Boone, R. D 1990. Soil organic matter as a potential net nitrogen sink in a fertilized cornfield, South Deerfield, Massachusetts, USA. Plant Soil 128, 191 - 198.

Buchanan, M., King, L. D. 1992. Seasonal fluctuations in microbial biomass carbon, phosphorus, and activity in no-till and reduced-chemical-input maize agroecosystems. Biol Fertil Soils 13, 211 - 217.

Bundy, L. G., Meisinger, J. J. 1994. Nitrogen availability indices. In: Weaver R. W. , Angle S., Bottomley P., Bezdicek D., Smith S., Tabatabai, A., Wollum, A, Mickelson, S. H., Bigham, J. M. (eds). Methods of soil analysis. Part 2. Microbial and biochemical properties. Number 5 in Soil Science of America Book Series, American Society of Soil Science, Madison, Wisconsin, USA, USA, 951 - 984.

Burket, J. Z., Dick, R. P. 1998. Microbial and soil parameters in relation to N mineralization in soils of diverse genesis under differing management systems. Biol Fertil Soils 27, 430 - 438.

Burns, R. G., Martin, J. P. 1986. Biodegradation of organic residues in soil. In: Mitchell M. J., Nakas, J. P. (eds). Microfloral and -fauna interactions in natural and agroecosystems. Nijhoff and Junk Publishers, Dordrecht, The Netherlands, 137 - 202.

Busto, M. D., Perez-Mateos, M. 1995. Extraction of humic-ß-glucosidase fractions from soils. Biol Fertil Soils $20,77-82$.

Campbell, C. A 1978. Soil organic carbon, nitrogen and fertility. In: Schnitzer M., Khan S. V. (eds). Soil organic matter. Developments in soil science 8. Elsevier Sci Publ, New York, 173 - 271.

Campbell, C. A., Myers, R. J. K., Weier, K. L. 1981. Potentially mineralizable nitrogen, decomposition rates and their relationship to temperature for five Queensland soils. Aust J Soil Res 19, 323 - 332.

Chhonkar, P. K., Tarafdar, J. C. 1984. Accumulation of phosphatases in soils. J Indian Soc Soil Sci 32, $266-272$.

Connell, M. J., Raison, R.J., Khanna, P. K. 1995. Nitrogen mineralization in relation to site history and soil properties for a range of Australian forest soils.. Biol Fertil Soils 24, 306 - 310. 
Craswell, E., Vlek, P. L. G. 1982. Nitrogen management for submerged rice soils. In symposium on submerged rice soils and their management. New Delhi: $12^{\text {th }}$ Int Congr Soil Sci 3, 158 - 181.

Dahnke, W. C., Johnson, G. V. 1990. Testing soils for available nitrogen. N: R. L. Westermann (ed), Soil testing and plant analysis, $3^{\text {rd }}$ ed. SSSA, Madison, WI, $127-139$.

Deng, S. P., Tabatabai, M. A. 1996. Effect of tillage and residue management on enzyme activities in soils: II. Glucosidases. Biol Fertil Soil 22, 208 - 213.

Deng, S. P., Tabatabai, M. A. 1997. Effect of tillage and residue management on enzyme activities in soils: III. Phosphatases and arylsulfatase. Biol Fertil Soil 24, 141 - 146.

De Willigen, P. 1991. Nitrogen turnover in the soil-crop ecosystem; comparison of fourteen simulation models. Fertil Res 27, 141 - 150.

Dick, R. P. 1992. A review: Long-term effects of agricultural systems on soil biochemical and microbial parameters. Agric Ecosys Environ 40, 25 - 36.

Dick, R. P. 1994. Soil enzyme activities as indicators of soil quality. In: Doran JW, Coleman D, Bezdicek DF, Stewart BA (eds). Defining soil quality for a sustainable environment. Soil Science Society of America, Madison, Wis., 107 - 124.

Dick, R. P., Rasmussen, P. E., Kerle, E. A. 1988. Influence of long-term residue management on soil enzyme activities in relation to soil chemical properties of a wheat-fallow system. Biol Fertil Soils 6, 159 - 164.

Diekmann, U. 1997. Biologische und chemische Bodencharaktersitika. Zur Beurteilung der nachhaltigen Produktivität von Landnutzungssystemen in der Zona Bragantina, Ost-Amazonien. Dissertation, University of Goettingen, Institute for Crop and Animal Production in the Tropics. Internet: http://webdoc.sub.gwdg.de/diss/1998/diekmann/inhalt.htm.

Domsch, K. H., Beck, T., Anderson, J. P. E., Söderström, B., Parkinson, D., Trolldenier, G. 1979. A comparison of methods for soil microbial population and biomass studies. Z Pflanzenernähr Bodenkd 142, 520 - 533.

Doran, J. W., Parkin, T. B, 1994. Defining and assessing soil quality. In: Defining Soil Quality for a sustainable Environment, 3 - 21. Soil Science Society of America, American Society of Agronomy, Special Publication Number 35.

Doran, J. W., Sarrantonio, M., Liebig, M. A. 1996. Soil health and sustainability. Adv Agron 56, 1 - 4.

Eivazi, F., Tabatabai, M. A. 1988. Glucosidases and galactosidases in soils. Soil Biol Biochem 20 (5), 601 606.

Elliott, L. F., Lynch, J. M., Papendick, R. I, 1996. The microbial component of soil quality. In: G. Stotzky (ed.). Soil Biochem 9, Marcel Dekker, 1 - 21.

FAO. Revised legend of the FAO-UNESCO Soil Map of the world. World Soil Res. Rep. 60, Rome 1988.

FAO stat online, 1998. Statistical Data Base, http://apps.fao.org/default.htm.

Fox, R. H., Pieckielek, W. P. 1984. Relationships among anaerobically mineralized nitrogen, chemical indexes, and nitrogen availability to corn. Soil Sci. Soc. Am. J. 48, 1087 - 1090.

Fox, T. R., Comerford, N. B. 1992. Rhizosphere phosphatase activity and phosphatase hydrolyzable organic phosphorus in two forested spodsols. Soil Biol Biochem, 24 (6), 579 - 583. 
Frankenberger, W. T., Dick, W. A. 1983. Relationships between enzyme activities and microbial growth and activity indices in soil. Soil Sci. Soc. Am. J. 47, 945 - 951.

Fraser, D. G., Haynes, R. J., Williams, P. H. 1995. Effects of pasture improvement and intensive cultivation on microbial biomass, enzyme activities, and composition and size of earthworm populations. Biol Fertil Soils 17, 185 - 190.

Friedel, J. K., Munch, J. C., Fischer, W. R. 1996. Soil microbial properties and the assessment of available soil organic matter in a haplic Luvisol after several years of different cultivation and crop rotation. Soil Biol Biochem 28 (4/5), 479 - 488.

Fugger, W., Vlek, P. L. G. 1998. Nutrient contribution of a cover crop fallow in the Sudan savanna region of Ghana. In: Renard, G., Neef, A., Becker K., Von Oppen, M. Soil fertility mangement in West African land use systems. Proceedings of the regional Workshop, University of Hohenheim, ICRISAT Sahelian Centre and INRAN, 4 - 8 March 1997, Niamey, Niger. Margraf Verlag, Weickersheim, Germany.

Gander, L. K., Hendricks, T., Costa, F. 1994. Microbial activity in soils under Mediterranean environmental conditions. Soil Biol Biochem 26 (9), 1185 - 1191.

Garcia, C., Hernandez, T., Doyle, J. D. 1994. Interferences, limitations and an improvement in the extraction and assessment of cellulase activity in soil. Soil Biol Biochem 26 (1), 65 - 73.

Garcia, C., Hernandez, T. 1997. Biological and biochemical indicators in derelict soils subject to erosion. Soil Biol Biochem 29 (2), 171 - 177.

Gonzales-Prieto, S. J., Cabaneiro, A., Villar, M. C., Carballas, M., Carballas, T. 1996. Effect of soil characteristics on $\mathrm{N}$ mineralization capacity in 112 native and agricultural soils from northwest of Spain. Biol Fertil Soil, 22, 252 - 260.

Ghoshal, N. Singh, K. P. 1995. Effects of farmyard manure and inorganic fertilizer on the dynamics of soil microbial biomass in a tropical dryland agroecosystem. Biol Fertil Soil 19, 231 - 238.

Goyal, S., Mishra, M. M., Dhankar, S. S., Kapoor, K. K., Batra, R. 1993. Microbial biomass turnover and enzyme activities following the application of farmyard manure to field soil with and without previous long term applications. Biol Fertil Soil 15, 60 - 64.

Groot, J. J. R., Houba, V. J. G. 1995. A comparison of different indices for nitrogen mineralization. Biol Fertil Soil 19, 1 - 9.

Haggar, J. P., Tanner, E. V. J., Beer, J. W., Kass, D. C. L. 1993. Nitrogen dynamics of tropical agroforestry and annual cropping systems. Soil Biol Biochem 25, (10), 1363 - 1375.

Härdter, R. 1989. Utilization of nitrogen and phosphorus by intercropping and sole cropping systems of maize (Zea Mays L.) and cowpea (Vigna Unguiculata L. ) on an alfisol in northern Ghana. Nyankpala Agricultural Research Report, No. 5, 1989.

Hart S. C., Stark J. M., Davidson E. A., Firestone M. K. 1994. Nitrogen mineralization, immobilization, and nitrification. In: Soil Science Society of America, 677 S. Segoe Rd., Madison, WI 53711, USA. Methods of Soil Analysis, Part 2. Microbiological and Biochemical Properties-SSSA Book Series, No.5, $985-1008$

Häussling, M., Marschner, H. 1989. Organic and inorganic soil phosphatases and acid phosphatase activity in the rhizosphere of 80-year-old Norway spruce trees. Biol Fertil Soils 8, 128 - 133. 
Hauffe, H.-K. 1989. Site characterization of the West Ridge Upland Experiment Area (NAES). In: Nyankpala Agricultural Research Report, No. 6, Annual Report 1987/88, NAES, 139 - 154.

Hayano, K. 1993. Protease activity in a paddy field soil: origin and some properties. Soil Sci Plant Nutr 39 (3), 539 - 546.

He, Z. I., Wu, J., O’Donell, A. G., Syers, J. K. 1987. Seasonal responses in microbial biomass carbon, phosphorus and sulphur in soils under pasture. Soil Sci Soc Am Proc 46, 970 - 976.

Hedley, M. J., Stewart, J. W. B, Chauhan, B. S. 1982. Changes in inorganic and organic soil phosphorus fractions induced by cultivation practices and by laboratory incubations. Soil Sci Soc Am Proc 46, $970-976$.

Hesse, J. 1997. Animal traction - a sustainable technology ? A longitudinal case study on the dynamics of identical farm-households in Northern Ghana. Dissertation 1998. Institute of rural development, University of Goettingen, Germany. Internet: http://207.36.32.220/library/112015xa.htm.

Hong, S. D., Fox, R. H., Piekielek, W. P. 1990. Field evaluation of several chemical indexes of soil nitrogen availability. Plant Soil 123, 83 - 88.

Hulugalle, N. R. 1992. Amelioration of highly degraded tropical Alfisol in south-eastern Nigeria. Expl Agric 26, 235 - 240.

IFDC, 1994. International Fertilizer Development Center; Ghana policy environment and fertilizer sector development. (Technical Bulletin; T 41).

IITA, 1979. Selected Methods for Soil and Plant Analysis (Manual Series No. 1, Revised Edition). Juo, A. S. R. (Editor). IITA, Ibadan, Nigeria.

Jarvis, S. C. 1996. Future trends in nitrogen research. Plant Soil 181, 47 - 56.

Jenkinson, D. S., Ladd, J. N. 1981. In: Paul E. A. \& Ladd J. N. (eds). Microbial biomass in soil: measurement and turnover. Soil Biochem 5. Decker, New York, 415 - 471.

Joergensen, R. 1995. Quantification of the microbial biomass by determining ninhydrin-reactive N. Soil Biol Biochem 28 (3), 301 - 306.

Joergensen, R., Brookes, P. 1990. Ninhydrin-reactive nitrogen measurements of microbial biomass in $0.5 \mathrm{M} \mathrm{K}_{2} \mathrm{SO}_{4}$ soil extracts. Soil Biol Biochem 22, (8), 1023 - 1027.

Jones, M. J., Wild, A. 1975. Soils of West African Savanna - maintenance and improvement of their fertility. Tech Comm 55. Comm Agric Bureau Herperden.

Jordan, D., Kremer, R. J., Bergfield, W. A., Kim, K. Y., Cacnio, V. N. 1995. Evaluation of microbial methods as potential indicators of soil quality in historical agricultural fields. Biol Fertil Soil, 19, 297 - 302.

Jost, A. 1997. Integrierter Getreideanbau in Nordghana unter besonderer Berücksichtigung der StrigaProblematik. PLITS No. 15 (4), 1997, Institut für Pflanzenproduktion in den Tropen und Subtropen Universität Hohenheim.

Jost A., Fugger W.-D., Kroschel J. \& Sauerborn J. 1996. Calopogonium und Pueraria als Bodendecker zur Verbesserung der Getreideproduktion in Nord-Ghana. Mitt. Ges. Pflanzenbauwiss. 9, 117-118.

Juo, A. S. R., Fox, R. L. 1977. Phosphate sorption characteristics of some bench-mark soils West Africa. Soil Sci 124, 370 - 376. 
Kandeler, E., Gerber, H. 1988. Short-term assay of soil urease activity using colorimetric determination of ammonium. Biol Fertil Soils 6, 68 - 72.

Kasei, C. N. 1993. A synopsis on the climate of the north of Ghana. In Proceedings: Workshop on improving farming systems in the interior savanna zone of Ghana. Nyankpala Agricultural Research Station. NAES Report 1993.

Keeney, D. R. 1982. Nitrogen-availability indices. In: Page A. L., Miller R. H., Keeney D. R. (eds). Methods of Soil Analysis, Part 2. Am Soc Inc, Soil Sci Soc Am Inc, Madison Wisconsin USA, 711 - 733.

Keeney, D. R. 1982a. Nitrogen inorganic forms. In: Page, A. L., Miller, R. H., Keeney, D. R. (eds). Methods of Soil Analysis, Part 2. Am Soc Agron Inc, Soil Sci Am Inc, Madison Wisconsin USA, 643 - 698.

Kirchner, M. J., Wollum, A. G. and King, L. D. 1993. Soil microbial populations and activities in reduced chemical input agroecosystems. Soil Sci Soc Am J 57, 1289 - 1295.

Kombiok, J. M., Rudat, H., Frey, E. 1995. Effect of short term Calopogonium fallow and different management practices on maize yields and soil properties in Northern Ghana. In: Proceedings of Seminar on organic and sedentary agriculture, 1.- 3. 11. 1995, Accra, Ghana. Ministry of Food and Agriculture, Ghana \& Deutsche Gesellschaft für Technische Zusammenarbeit.

Kranz B., Fugger W. D., Kroschel J., Sauerborn J. (1998) The influence of organic manure on Striga hermonthica (Del.) Benth. infestation in northern Ghana. In: HP Blume, H Egger, E. Fleischhauer, A Hebel, C Reij, K.G. Steiner (eds.), Towards Sustainable Land Use: furthering cooperation between people and institutions. Advances in GeoEcology 31 (I), 615 - 619.

Kuo, S., Sainju, U. M., Jellum, E. 1996. Winter cover cropping influence on nitrogen mineralization, presidedress soil nitrate test, and corn yields. Biol Fertil Soils 22, 310 - 317.

Ladd, J. N. 1972. Properties of proteolytic enzymes extracted from soil. Soil Biol Biochem 4, 227 - 237.

Ladd, J. N. 1978. Origin and range of enzymes in soil. In: Soil Enzymes. Burns, R.G. (ed). Academic Press, New York, USA, 55 - 96.

Ladd, J. N., Butler, J. H. A. 1972. Short-term assays of soil proteolytic enzyme activities using proteins and dipeptide derivatives as substrates. Soil Biol Biochem 4, 19 - 30.

Lal, R. 1989. Agroforestry systems and soil surface management of a tropical Alfisol. III. Changes in chemical properties. Agroforest Syst 8, 113 - 132.

Lal, R., Ghuman, B., Shearer, W. 1990. Sustainability of different agricultural production systems for a rainforest zone of southern Nigeria. Transactions $14^{\text {th }}$ International Congress of Soil Science, Kyoto, Japan, VI, 186 - 191.

Landon, J. R. (ed), 1991. Booker Tropical Soil Manual: A Handbook for Soil Survey and Agricultural Land Evaluation in the Tropics and Subtropics. Booker Tate, Thame, Oxon, UK.

Langyintuo, A. S., Dogbe, W. 1998. Economic feasibility of the use of improved fallow system in rice production systems in the Guinea savanna zone of Ghana. In: Renard, G., Neef, A., Becker K., Von Oppen, M. Soil fertility mangement in West African land use systems. Proceedings of the regional Workshop, University of Hohenheim, ICRISAT Sahelian Centre and INRAN, 4 - 8 March 1997, Niamey, Niger. Margraf Verlag, Weickersheim, Germany.

Larson, W. E., Pierce, F. J. 1991. Conservation and enhancement of soil quality. In: 24: Evaluation for sustainable land management in the developing world, vol 2. Tech Pap, Bangkok, Int Board for Soil Research Management, IBSRAM Proceedings No 12. 
Liang, B. C., MacKenzie, A. F. 1996. Changes in soil organic carbon and nitrogen after six years of corn production. Soil Sci 153, 307 - 313.

Logan, T. J. 1990. Chemical Degradation of Soil. In: Lal, R. and Stewart, B. Soil degradation. Adv Soil Sci, 11, 187 - 221.

Loll, M. J., Bollag, J. M. 1983. Protein transformation in soil. Adv Agron 36, 351 - 382.

Lopez-Hernandez, D., Nino, M., Nannipieri, P., Fardeau, J. C, 1989. Phosphatase activity in Nasutitermes ephratae termite nests. Biol Fertil Soils 7, 134 - 137.

Lynch, J. M., Panting, L. M. 1980a. Cultivation and the soil biomass. Soil Biol Biochem 12, 29 - 33.

Lynch, J. M., Panting, L. M. 1980b. Variations in the size of the soil biomass. Soil Biol Biochem 12 , 547 - 550.

Martens, R. 1995. Current methods for measuring microbial biomass C in soil: Potentials and limitations. Biol Fertil Soil 19, 87 - 99.

Martens, D. A., Johanson, J. B., Frankenberger, W. T. 1992. Production and persistence of soil enzymes. Soil Sci 153 (1), 53 - 61.

Mazzarino, M. J., Szott, L., Jimenez, M. 1993. Dynamics of soil total C and N, Microbial biomass, and water-soluble C in tropical Agroecosystems. Soil Biol Biochem 25 (2), 205 - 214.

McCarty, G. W., Meisinger, J. J. 1997. Effects of N fertilizer on biologically active N pools in soils under plow and no tillage. Biol Fertil Soil 24, 406 - 412.

McCracken, D. V., Corak, S. J., Smith, M. S., Frye, W. W., Blevins, R. L. 1989. Residual effects of nitrogen fertilization and winter cover cropping on nitrogen availability. Soil Sci. Soc. J. 53, 1459 - 1464.

Meisinger, J. J. 1984. Evaluating plant-available nitrogen in soil-crop systems. In R. D. Hauck et al. (ed.), Nitrogen in crop production. ASA, Madison, WI, 391 - 416.

Mengel, K. 1996. Turnover of organic nitrogen in soils and its availability to crops. Plant Soil 181, 83 - 93.

Meyer, P. 1993. Reiseführer Ghana.

Model Maker Version 2.0, 1995, SB Technology, Cherwell Scientific Publishing Limited. The Magdalen Centre, Oxford Science Park, Oxford OX44GA, Great Britain.

MOA 1993, 1995. Policy Planning, Monitoring and Evaluation Department (PPMED), Ministry of Agriculture (MOA), Ghana.

Moroko, J. B., Buresh, R. J., Smithson, P. C. 1998. Soil nitrogen availability as affected by fallow-maize systems on two soils in Kenya. Biol Fertil Soils 26, 229 - 234.

Nannipieri, P., Grego, S., Ceccanti, B. 1990. Ecological significance of the biological activity in soil. Soil Biochem 6, 293 - 355.

Nakas J. P., Gould, W. D., Klein, D. A. 1987. Origin and expression of phosphatase activity in a semi-arid grassland soil. Soil Biol Biochem 19 (1), 13 - 18.

Nye, P. H, Greenland, D., J. 1960. The soil under shifting cultivation. Commonwealth Bureau Soils Techn. Comm. No 51, Harpenden England, 319 - 337.

Olsen, S. R., Sommers, L. E. 1982. Phosphorus. In: A. L. Page, R. H. Miller and D. R. Keeney (eds). Methods of soil analysis, Part 2. Chemical and microbiological properties - Agronomy Monograph No. 9 ( $2^{\text {nd }}$ ed.), 403 - 430, Wisconsin, USA. 
Omay, A. B., Rice, C. W., Maddux, L. D. Gordon, W. B. 1997. Changes in soil microbial and chemical properties and long-term crop rotation and fertilization. Soil Sci Soc Am J 61, 1672 - 1678.

Owusu-Bennoah, E., Acquaye, D K., Abekoe, M. 1991. Efficient fertilizer use for increased crop production: Use of phosphorus fertilizers in concretional soils of Northern Ghana. In: Mokwunye, A. U. (Ed). Allevating soil fertility constraints to increased crop production in West Africa, Vol. 29 (1), 181 - 1194. Kluwer Academic Publishers, 1991.

Oyovbisere, E. O., Lombim, G. 1991. Efficient fertilizer use for increased crop production: The sub-humid Nigeria experience. In: Allevating soil fertility constraints to increased crop production in West Africa, Vol. 29 (1), 181 - 1194. Mokwunye, A. U. (Ed). Kluwer Academic Publishers, 1991.

Paniagua, A., Mazzarino, M. J., Kass, D., Szott, L., Fernandez, C. 1995. Soil phosphorus fractions under five tropical agroecosystems on a volcanic soil. Aust J Soil Res 33, 311 - 320.

Pankhurst, C. E., Hawke, B. G., McDonald, H. J., Kirkby, C. A. Buckerfield, J. C., Michelsen, P. A. O’Brian, K. A., Gupta, V. V. S. R., Doube, B. M. 1995. Evaluation of soil biological properties as potential bioindicators as soil health. Aust J Exp Agric 35, 1015 - 1028.

Parr, J. F., Papendick, R. I., Hornick, S. B., Meyer, R. E. 1992. Soil quality- Attributes and relationships to alternative and sustainable agriculture. Am J Alternativ Agric 7, 5 - 11.

Parton, W. J., Schimel, D. S., Cole, C. V., Ojima, D. S. 1987. Analysis of factors controlling soil organic matter levels in Great Plains Grasslands. Soil Sci Soc Am J 51, 1173 - 1179.

Perott, K. W., Saratchandra, S. U., Waller, J. E. 1990. Seasonal storage and release of phosphorus and potassium by organic matter and the microbial biomass in a high-producing pastoral soil. Aust J Soil Res 28, 593 - 608 .

Perucci, P. 1992. Enzyme activity and microbial biomass in a field soil amended with municipal refuse. Biol Fertil Soil 14, 54 - 60.

Poss, R., Faradeu, J. C., Saragoni, H. 1997. Sustainable agriculture in the tropics: the case of potassium under maize cropping in Togo. Nutr Cycl Agroecosyst 46, 205 - 213.

Powlson, D. S. 1994. The soil microbial biomass: before, beyond and back. In: K. Ritz, J. Dighton and K. E. Giller (eds). Beyond the biomass. British Society of Soil Science (BSSS), Wiley Sayce, Chichester, UK, 3 - 20 .

Rasmussen, P. E., Douglas, J. R., Collins, H. P., Albrecht, S. L. 1998. Long-term cropping system effects on mineralizable Nitrogen in soil. Soil Biol Biochem 30 (13), 1829 - 1837.

Rastin, P. E, Rosenplänter, K., Hüttermannn, A. 1988. Seasonal variation of enzyme activity and their dependence on certain soil factors in a beech forest soil. Soil Biol Biochem 20 (5), 637 - 642.

Reganold, J. P., Palmer, A. S., Lockhart, J. C., MacGregor, A. N. 1993. Soil quality and financial performance of biodynamic and conventional farms in New Zealand. Science 260, 344 - 349.

Rhodes, E. R. 1988. Africa - how much fertilizer needed: Case study of Sierra Leone. Fert Res 17, 101 - 118.

Rhodes, E. R. 1995. Nutrient Depletion by food crops and soil organic nitrogen management. Agric Syst 48, $101-118$.

Roper, M. M., Gupta, V. V. S. R. 1995. Management practices in soil biota. Aust J Soil Res 33, 321 - 331.

Rudat, H., Mercer-Quarshie, H. 1993. Proceedings of the $2^{\text {nd }}$ Workshop on improving farming systems in the interior savanna zone of Ghana. 24 - 26 April, 1990, Nyankpala, Ghana. 
Runge-Metzger, A., Diehl, L. 1993. Farm household systems in northern Ghana. A case study in farming systems oriented research for the development of improved crop production systems. Nyankpala Agricultural Research Report No.9.

Ruthenberg, H. 1980. Farming Systems in the Tropics. 3. Edition, Clarendon Press, Oxford, UK.

Salifu, A. B. 1993. Towards accelerated agricultural productivity and output in the northern guinea and sudan savanna zones of Ghana, pp 27 - 36. In: Proceedings of the $2^{\text {nd }}$ Workshop on improving farming systems in the interior savanna zone of Ghana. 24 - 26 April, 1990, Nyankpala, Ghana.

Sanchez, P. A,. Izac, A.-M., Valencia, I., Pieri, C. 1996. Soil fertility replenishment in Africa: a concept note. ICRAF.

Sarathchandra, S. U., Perrot, K. W., Upsdell, M. P. 1984. Microbial and biochemical characteristics of a range of New Zealand soils under established pasture. Soil Biol Biochem 16, 177 - 184.

Sarkar, J. M., Leonowicz, P. Bollag, J. M. 1989. Immobilization of enzymes on clays and soils. Soil Biol Biochem 21 (2), 223 - 230.

Scharpf, H. J., Wehrmann J. 1976. Die Bedeutung des Mineralstickstoffvorrates das Bodens zu Vegetationsbeginn für die Bemessung der N-Düngung zu Winterweizen. Landw Forsch 32, 100 - 114.

Schinner, F., Öhlinger, R., Kandeler, E. 1991. Bodenbiologische Arbeitsmethoden. Springer Verlag Berlin Heidelberg.

Schlichting, E., Blume, H. P. 1966. Bodenkundliches Praktikum. Parey Verlag Hamburg Berlin.

Skujins, J. 1976. Extracellular enzymes in soil. CRC Critical Rev Microbiol 4, 383 - 421.

Smith, J. L. Paul E. A. 1990. The significance of soil microbial biomass estimations. Soil Biochem 6, $357-396$.

Smith, J. L., Papendick, R. I., Bezdicek, D. F. and Lynch, J. M. 1993. Soil organic matter dynamics and crop residue management. In: F. Blaine Metting, Jr. (ed). Soil Microbial Ecology, Marcel Dekker, New York, $65-93$.

Smith, J. L., Halverson, J. J., Papendick, R. I. 1993a. Using multivariate indicator kriging for evaluating soil quality. Soil Sci Soc Am J 57, 743 - 749.

Sparling, G. P, Speir, T. W., Whale, K. N. 1986. Changes in microbial biomass C, ATP content, soil phosphomonoesterase and phosphodiesterase activity following air-drying of soils. Soil Biol Biochem 18 (4), 363 - 370.

Sparling, G. P. 1992. Ratio of microbial carbon to soil organic carbon as a sensitive indicator of changes in soil organic matter. Aus J Soil Res 30, 195 - 207.

Speir, T. W., Ross, D. J. 1978. Soil phosphatase and sulphatase. In: Burns R. G. (ed). Soil Enzymes. Academic Press, London, New York, San Francisco.

Speir, T. W., Cowling, J. C. 1991. Phosphatase activities of pasture plants and soils: relationship with plant productivity and soil P fertility indices. Biol Fertil Soils 12, 189 - 194.

Sprent, J. I. 1987. The ecology of the nitrogen cycle. Cambridge University Press.

Sprich, H. 1994. Bedeutung der Fruchtfolge zur Ertragssicherung in getreidebetonten Produktionssystemen der Guinea-Savanne unter besonderer Berücksichtigung des parasitischen Unkrautes Striga hermonthica. PLITS No. 12 (2), 1994, Institut für Pflanzenproduktion in den Tropen und Subtropen Universität Hohenheim. 
Srivastava, S. C. 1992. Influence of soil properties on microbial C, N, and P in dry tropical ecosystems. Biol Fertil Soils 13, 176 - 180.

Srivastava, S. C., Singh, J. S. 1988. Carbon and phosphorus in soil biomass of some tropical soils of India. Soil Biol. Biochem 20, 743 - 747.

Srivastava, S. C., Singh, J. S. 1991. Microbial C, N and P in dry tropical forest soils: Effects of alternate land-uses and nutrient flux. Soil Biol. Biochem 23, 117 - 124.

Stanford G. 1982. Assessment of nitrogen availability. In: Stevenson F. J. (ed), Nitrogen in agricultural soils. Agron. Monogr. 22, 651 - 688. ASA and SSSA, Madison, WI.

Stewart, J. W., Tiessen, H. 1987. Dynamics and soil organic phosphorus. Biogeochemistry 4, 41 - 60.

Stoorvogel, J. J., Smaling, E. M. A. 1990. Assessment of soil nutrient depletion in Sub-Saharan Africa. The Winand Staring Centre for Integrated Soil and Water Research, Wageningen, The Netherlands.

Stumpe, J. M, Vlek, P. L. G. 1991. Acidification induced by different nitrogen sources in columns of selected tropical soils. Soil Sci Soc Am J 55 (1), 145 - 151.

SYSTAT for Windows 1992, Statistics, Version 5 Edition, Evanston, Illinois, USA, Systat Inc., 750 pp.

Tabatabai, M. A. 1982. Soil Enzymes. In: A. L. Page, R. H. Miller and D. R. Keeney (eds). Methods of soil analysis, Part 2. Chemical and microbiological properties - Agronomy Monograph No. 9 ( $2^{\text {nd }}$ ed.), 903 - 947, Wisconsin, USA.

Tabatabai, M. A. 1994. Soil Enzymes. In: Methods of soil analysis, Part 2. Microbiological and biochemical properties, 775 - 833, SSSA, Wisconsin, USA.

Tabatabai, M. A. and Bremner, J. M. 1969. Use of p-nitrophenylphosphate for assay of soil phosphatase activity. Soil Biol Biochem 1, 301 - 307.

Tadano T., Ozawa, K., Sakai, H, Matsui, H. 1993. Secretion of acid phosphatase by the roots of crop plants under phosphorus-deficient conditions and some properties of the enzyme secreted by lupin roots. Plant Soil 155/156, 95 - 98.

Tessier, L., Gregorich, E G., Topp, E. 1998. Spatial variation of soil microbial biomass measured by the fumigation extraction method, and $\mathrm{K}_{\mathrm{ec}}$ as affected by depth and manure application. Soil Biol Biochem 30, No. 10/11, 1369 - 1377.

Tiessen, H., Stewart, J W. B., Moir, J. O. 1983. Changes in organic and inorganic phosphorus composition of two grassland soils and their particle size fractions during 60-90 years of cultivation. J Soil Sci 34, 815 - 823.

Tiessen, H., Frossard E., Mermut A. R., Nyamekye A. L. 1991. Phosphorus sorption, and properties of ferruginous nodules from semiarid soils from Ghana and Brazil. Geoderma 48, 373 - 390.

Tiessen, H., Salcedo, I. H., Sampaio, E. V. S. B. 1992. Nutrient and soil organic matter dynamics under shifting cultivation in semi-arid northeastern Brazil. Agriculture, Ecosystems and Environment 38, $139-151$.

Trasar-Cepeda, C. Leiros, F., Gil-Sotres, F., Seoane, S. 1998. Towards a biochemical quality index for soils: An expression relating several biological and biochemical properties. Biol Fertil Soils 26, 100 - 106.

Turco, R. F. Kennedy, A. C., Stott, D. E. 1994. Microbial indicators for soil quality. In: Doran JW, Coleman D, Bezdicek DF, Stewart BA (eds). Defining soil quality for a sustainable environment. Soil Science Society of America, Madison, Wis., 73 - 90. 
UNEP-ISRIC 1991. GIS evaluation of GLASOD map. Nairobi, Kenya: UNEP/ISRIC

Visser, S., Parkinson, D. 1992. Soil biological criteria as indicators of soil quality. Am J Alternative Agric 7 , 33 - 37.

Vlek, P. L. G. 1993. Strategies for sustaining agriculture in sub-Saharan Africa: The fertilizer technology issue. American Society of Agronomy, Crop Science Society of America, and Soil Science Society of America. Technologies for sustainable agriculture in the tropics. ASA Special Publication 56, 265 - 277.

Vlek, P. L. G., Kühne, R. F., Denich, M. 1997. Nutrient resources for crop production in the tropics. Phil. Trans. R. Soc. Lond. B 352. 975 - 985.

Vuorinen, A. H., Saharinen, M. H. 1996. Effects of soil organic matter extracted from soil on acid phosphomonoesterase. Soil Biol Biochem 10 (11), 1477 - 1481.

Wardle, D. A. 1998. Controls of temporal variability of the soil microbial biomass: A global-scale synthesis. Soil Biol Biochem 30 (13), 1627 - 1637.

Warren, G. P., Atwal, S. S., Irungu, T. 1997. Soil nitrate variations under grass, - sorghum and bare fallow in semi-arid Kenya. Expl Agric 33, 321 - 333.

Weber, G., Chude, V., Pleysier, J., Oikeh, S. 1995. On-farm evaluation on nitrate-nitrogen dynamics under maize in the northern Guinea savanna of Nigeria. Expl Agric 31, 333 - 344.

Weigand, S., Auerswald, K., Beck, T. 1995. Microbial biomass in agricultural top soils after 6 years of bare fallow. Biol Fertil Soils 19, 129 - 134.

Wick, B. 1997. Microbiological indicators for quality of soils at various stages of degradation in the forestsavanna-transition zone, south-western Nigeria. Dissertation, University of Goettingen, Institute of Agriculture in the Tropics and Subtropics. Internet: http: //webdoc.sub.gwdg.de/diss/1997/wick/inhalt.htm.

Wick, B., Kühne, R. F., Vlek, P. L. G. 1998. Soil microbiological parameters as indicators of soil quality under improved fallow management systems in south-western Nigeria. Plant Soil 202, 97 - 107.

Yakovchenko, V., Sikora, L. D., Kaufman, D. D. 1996. A biologically based indicator of soil quality. Biol Fertil Soil 21, 245 - 251. 


\section{Annex}

Table 40: Time schedule for the agronomic measures in 1993.

\begin{tabular}{|lll|}
\hline Agronomic measure & $\mathrm{CH} 1$ & $\mathrm{CH} 2$ \\
Soil sampling & 13.06 .93 & 14.06 .93 \\
Application of cotton seed waste & 19.06 .93 & 19.06 .93 \\
Sowing of maize and application of TSP & 22.06 .93 & 23.06 .93 \\
1. N-rate and application of K, Ca, Mg, S, Mo and Zn fertilizer & 03.07 .93 & 03.07 .93 \\
1. Weeding & 14.07 .93 & 14.07 .93 \\
Thinning out to 1 maize plant per stand & 20.07 .93 & 20.07 .93 \\
2. N-rate & 28.07 .93 & 28.07 .93 \\
2. Weeding & 04.08 .93 & 04.08 .93 \\
Hoeing and ridging to improve maize stand & 13.09 .93 & 13.08 .93 \\
Maize harvest & 11.10 .93 & 12.10 .93 \\
Soil sampling & 13.10 .93 & 14.10 .93 \\
\hline
\end{tabular}

Table 41: Time schedule for the agronomic measures in 1994.

Soil sampling
Application of cotton seed waste
Sowing of maize and application of TSP
1. Weeding
1. N-rate and application of $\mathrm{K}, \mathrm{Ca}, \mathrm{Mg}, \mathrm{S}$, Mo and $\mathrm{Zn}$
1. Application of Basudan against army worm outbreak
2. Application of Basudan against army worm outbreak
Ridging of maize
Thinning of maize (1 plant stand $\left.{ }^{-1}\right)$
2. N-rate
3. Application of Dursban against army worm outbreak
2. Weeding
3. Weeding by hand
Hoeing and ridging to improve maize stand
4. Application of Karate, ULV
Maize harvest
Soil sampling

$\mathrm{CH} 2$

16. 06.94

17. 06.94

22. 06.94

22. 06.94

23. 06.94

25. 06.94

06. 07.94

07. 07.94

08. 07.94

10. 07.94

11. 07.94

11. 07.94

13. 07.94

13. 07.94

19. 07.94

20. 07.94

27. 07.94

27. 07.94

12. 08.94

12. 08.94

13. 07.94

13. 07.94

01.08 .94

01.08 .94

31. 08.94

01.09 .94

20. 09.94

22. 09.94

21. 09.94

21. 09.94

20. 10.94

24. 10.94

21. 10.94

25. 10.94

${ }^{a}$ Ulta low volume 
Table 42: Time schedule for the agronomic measures in 1995.

\begin{tabular}{|lll|}
\hline Agronomic measure & CH 1 & CH 2 \\
$\begin{array}{l}\text { Determination of spontaneous bush fallow regrowth } \\
\text { in minus-one trials }\end{array}$ & 14.06 .95 & 14.06 .95 \\
Soil sampling & 20.06 .95 & 20.06 .95 \\
Application of cotton seed waste & 20.06 .95 & 20.06 .95 \\
Sowing of maize and application of TSP & 21.06 .95 & 22.06 .95 \\
1. N-rate and application of K, Ca, Mg, S, Mo and Zn & 05.07 .95 & 06.07 .95 \\
Application of Karate ULV against army worm outbreak & 05.07 .95 & \\
Thinning of maize (1 plant stand $\left.{ }^{-1}\right)$ & 18.07 .95 & 19.07 .95 \\
Soil sampling & 12.07 .95 & 12.07 .95 \\
1. Weeding & 19.07 .95 & 20.07 .95 \\
Soil sampling & 11.08 .95 & 11.08 .95 \\
2. N-rate & 14.08 .95 & 14.08 .95 \\
Ridging of maize plants & 23.08 .95 & 24.08 .95 \\
2. Weeding & 04.09 .95 & 04.09 .95 \\
Soil sampling & 01.09 .95 & 01.09 .95 \\
Soil sampling & 21.09 .95 & 21.09 .95 \\
Maize harvest & 09.10 .95 & 10.10 .95 \\
Soil sampling & 11.10 .95 & 12.10 .95 \\
\hline
\end{tabular}

Table 43: Time schedule for soil sampling during 1993-1995.

\begin{tabular}{|c|c|c|c|c|}
\hline \multicolumn{5}{|l|}{ Sampling date } \\
\hline \multicolumn{2}{|c|}{$\begin{array}{l}\text { chemical and pysical microbial soil analysis } \\
\text { soil analysis }\end{array}$} & $\begin{array}{l}\text { mineral } \mathrm{N} \\
\left(\mathrm{N}_{\text {min }}\right)\end{array}$ & \multicolumn{2}{|c|}{$\begin{array}{l}\mathrm{N} \text { mineralisation } \\
\text { incubation method }\end{array}$} \\
\hline $13 / 14.06 .93$ & $13 / 14.06 .93$ & & & \\
\hline 13.10 .93 & 13.10 .93 & & & \\
\hline $16 / 17.06 .94$ & $16 / 17.06 .94$ & & & \\
\hline $21 / 24.10 .93$ & $21 / 24.10 .93$ & & & \\
\hline \multirow[t]{5}{*}{20.06 .95} & 20.06 .95 & 20.06 .95 & 20.06 .95 & 20.06 .95 \\
\hline & & 12.07 .95 & & \\
\hline & & 11.08 .95 & 11.08 .95 & 11.08 .95 \\
\hline & & 01.09 .95 & & \\
\hline & & 21.09 .95 & & \\
\hline 11.10 .95 & 11.10 .95 & 11.10 .95 & & \\
\hline
\end{tabular}


Table 44: Methods of soil analyses.

\section{Soil parameter}

Soil physical parameter

Particle size distribution

Bulk density

Soil chemical parameter

$\mathrm{pH}$

Organic Carbon $\left(\mathrm{C}_{\text {org }}\right)$

Cation exchange capacity (CEC)

Base saturation

Exchangeable cations

(K, Ca, Mg, Mn, Zn)

Total nitrogen $\left(\mathrm{N}_{\mathrm{t}}\right)$

Available phosphate

Organic phosphate

Extractable sulfate-S

Mineral Nitrogen $\left(\mathrm{N}_{\min }\right)$

$\left(\mathrm{NO}_{3}-\mathrm{N}, \mathrm{NH}_{4}-\mathrm{N}\right)$

Nitrogen mineralisation

(aerobic incubation)

Nitrogen mineralisation

(anaerobic incubation)

Soil microbiological parameter

Microbial biomasse

ß-Glucosidase activity

Acid phosphatase activity

Alkaline phosphatase activity

Protease activity

\section{Method}

Pipette methode (SCHLICHTING \& BLUME, 1966)

BLAKE \& HARTGE (1986)

$0,01 \mathrm{M} \mathrm{Cacl}_{2}($ soil: solution $=1: 2.5)$

WALKLEY\& BLACK (1954) (as cited by IITA, 1979)

$\mathrm{NH}_{4}$-acetate methode (IITA, 1979)

Sum of bases expressed as a fraction of CEC x 100

Methods (IITA, 1979)

Kjeldal methode (as cited by IITA, 1979)

Bray-I methode (as cited by IITA, 1979)

OLSON \& SOMMERS (1982)

$\mathrm{KH}_{2} \mathrm{PO}_{4}$ Extraction method (as cited by IITA, 1979)

Methods for $\mathrm{NH}_{4}-\mathrm{N}$ and $\mathrm{NO}_{3}-\mathrm{N}$ determination as cited by ALEF (1991)

KEENEY \& BREMNER, (1966) modified by Beck (1983) as cited by SCHINNER et al. (1991)

KEENEY, (1982) as cited by SCHINNER et al (1991)

Fumigation and Extraction, according to BROOKES et al. (1985) modified by AMATO \& LADD (1988) as cited by SCHINNER et al. (1991)

EIVAZI \& TABATABAI (1988) as cited by ALEF (1991)

TABATABAi \& BREMNER (1969), EIVAZI \& TABATABAI, (1977) as cited by SCHINNER et al. (1991)

TABATABAi \& BREMNER (1969), EIVAZI \& TABATABAI, (1977) as cited by SCHINNER et al. (1991)

LADD \& BUTLER (1972) as cited by SCHINNER et al. (1991) 
Table 45: Nutrient concentration in maize grains at final harvest of the third cropping cycle in October 1995 after three years of different nutrient application in the minus-one trials. Locations: $\mathrm{CH} 1$ (not degraded) and $\mathrm{CH} 2$ (degraded).

Nutrient concentration

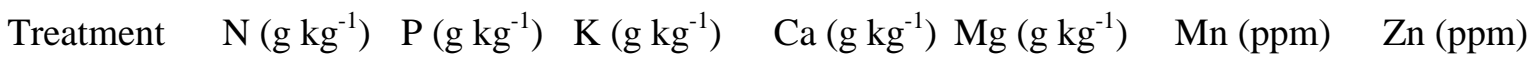

\section{CH 1 (not degraded)}

$\begin{array}{lccccccc}\text { All } & 19.6 & 4.4 & 12.4 & 0.1 & 1.0 & 63 & 26 \\ \text { All org } & 18.4 & 4.6 & 13.1 & 0.3 & 1.2 & 60 & 29 \\ \text {-N } & 15.2 & 3.5 & 11.2 & 0.3 & 1.0 & 41 & 27 \\ \text {-P } & 17.4 & 3.3 & 10.8 & 0.3 & 1.0 & 64 & 36 \\ -\mathrm{K} & 18.6 & 4.6 & 13.7 & 0.2 & 1.2 & 64 & 30 \\ \text {-Ca/org } & 15.7 & 3.8 & 11.1 & 0.2 & 1.0 & 56 & 26 \\ \text {-Mg } & 19.1 & 4.3 & 13.8 & 0.3 & 1.2 & 46 & 30 \\ \text {-S } & 18.3 & 4.4 & 12.2 & 0.2 & 1.1 & 64 & 30 \\ \text {-Mo/-Zn } & 19.1 & 4.6 & 14.2 & 0.1 & 1.1 & 65 & 28 \\ \text { None } & 14.5 & 3.6 & 10.5 & 0.3 & 0.9 & 62 & 28 \\ \text { Mean } & 17.6 & 4.1 & 12.3 & 0.2 & 1.1 & 59 & 29 \\ \text { LSD } & 2.0 & 0.7 & 1.5 & - & - & - & - \\ \text { F-Test } & * * * & * * * & * * * & \text { ns } & \text { ns } & \text { ns } & \text { ns }\end{array}$

CH 2 (degraded)

\begin{tabular}{lccccccc} 
All & 18.5 & 4.7 & 12.7 & 0.7 & 1.3 & 68 & 24 \\
All org & 18.6 & 4.4 & 13.3 & 0.6 & 1.3 & 72 & 24 \\
$-\mathrm{N}$ & 14.2 & 3.9 & 11.5 & 0.7 & 0.9 & 52 & 24 \\
$-\mathrm{P}$ & 18.5 & 2.5 & 10.6 & 0.8 & 1.0 & 75 & 32 \\
$-\mathrm{K}$ & 18.0 & 4.2 & 13.3 & 0.7 & 1.3 & 75 & 27 \\
-Ca/org & 14.8 & 3.9 & 12.3 & 0.6 & 1.1 & 68 & 24 \\
$-\mathrm{Mg}$ & 17.8 & 4.7 & 13.2 & 0.7 & 1.2 & 60 & 24 \\
$-\mathrm{S}$ & 17.2 & 4.3 & 11.4 & 0.6 & 1.1 & 69 & 25 \\
$-\mathrm{Mo} / \mathrm{Zn}$ & 17.1 & 4.6 & 14.0 & 0.7 & 1.3 & 70 & 25 \\
$\mathrm{None}$ & 14.1 & 2.9 & 10.3 & 0.7 & 1.0 & 69 & 25 \\
Mean & 16.8 & 4.0 & 12.3 & 0.7 & 1.2 & 68 & 26 \\
LSD & 2.0 & 0.9 & 2.1 & - & - & - & - \\
F-Test & $* * *$ & $* * *$ & $* * *$ & $\mathrm{~ns}$ & $\mathrm{~ns}$ & $\mathrm{~ns}$ & $\mathrm{~ns}$ \\
\hline
\end{tabular}


Table 46: Nutrient concentration in maize stover at final harvest of the third cropping cycle in October 1995 after three years of different nutrient application in the of minus-one trials. Locations: $\mathrm{CH} 1$ (not degraded) and $\mathrm{CH} 2$ (degraded).

Nutrient concentration

Treatment $\quad \mathrm{N}\left(\mathrm{g} \mathrm{kg}^{-1}\right) \quad \mathrm{P}\left(\mathrm{g} \mathrm{kg}^{-1}\right) \quad \mathrm{K}\left(\mathrm{g} \mathrm{kg}^{-1}\right) \quad \mathrm{Ca}\left(\mathrm{g} \mathrm{kg}^{-1}\right) \quad \mathrm{Mg}\left(\mathrm{g} \mathrm{kg}^{-1}\right) \quad \mathrm{Mn}(\mathrm{ppm}) \quad \mathrm{Zn}(\mathrm{ppm})$

CH 1 (not degraded)

$\begin{array}{lccccccc}\text { All } & 6.8 & 0.7 & 21.1 & 0.8 & 0.8 & 29 & 16 \\ \text { All org } & 6.9 & 0.7 & 27.3 & 0.9 & 0.9 & 26 & 16 \\ \text {-N } & 4.6 & 1.7 & 17.8 & 0.6 & 1.0 & 29 & 26 \\ \text {-P } & 8.3 & 0.5 & 20.7 & 0.9 & 1.1 & 26 & 29 \\ -\mathrm{K} & 7.1 & 0.7 & 16.5 & 0.9 & 1.0 & 24 & 14 \\ \text {-Ca/org } & 5.7 & 0.9 & 16.7 & 0.7 & 0.8 & 27 & 20 \\ -\mathrm{Mg} & 6.2 & 1.0 & 17.8 & 0.9 & 0.8 & 28 & 13 \\ -\mathrm{S} & 6.8 & 0.9 & 21.9 & 0.9 & 0.9 & 30 & 13 \\ -\mathrm{Mo} / \mathrm{Zn} & 7.1 & 0.8 & 21.4 & 0.9 & 0.8 & 24 & 12 \\ \text { None } & 5.1 & 1.0 & 15.7 & 0.8 & 1.0 & 28 & 26 \\ \text { Mean } & 6.5 & 0.9 & 19.7 & 0.8 & 0.9 & 27 & 18 \\ \text { LSD } & 1.5 & 0.6 & 4.2 & 0.2 & 0.2 & - & 7 \\ \text { F-Test } & * * * & * & * * * & * & * * * & \mathrm{~ns} & * * *\end{array}$

CH 2 (degraded)

\begin{tabular}{lrrrrrrr} 
All & 6.8 & 0.7 & 15.2 & 0.8 & 0.8 & 134 & 17 \\
All org & 7.4 & 0.8 & 19.0 & 0.9 & 0.8 & 120 & 21 \\
-N & 5.0 & 1.8 & 13.9 & 0.6 & 0.9 & 123 & 29 \\
-P & 10.0 & 0.4 & 14.7 & 0.8 & 1.1 & 232 & 56 \\
$-\mathrm{K}$ & 7.8 & 0.6 & 10.2 & 0.9 & 1.2 & 152 & 26 \\
$-\mathrm{Ca} / \mathrm{org}$ & 5.0 & 0.6 & 11.8 & 0.7 & 0.8 & 164 & 25 \\
$-\mathrm{Mg}$ & 7.0 & 0.6 & 14.2 & 1.0 & 0.7 & 185 & 17 \\
$-\mathrm{S}$ & 6.4 & 0.6 & 21.9 & 0.8 & 0.8 & 134 & 20 \\
$-\mathrm{Mo} / \mathrm{Zn}$ & 7.0 & 0.8 & 12.8 & 0.9 & 0.9 & 157 & 14 \\
None & 5.2 & 0.4 & 9.8 & 0.8 & 0.9 & 210 & 28 \\
Mean & 6.8 & 0.7 & 14.3 & 0.8 & 0.9 & 161 & 25 \\
LSD & 1.8 & 0.3 & 4.9 & 0.2 & 0.2 & 66 & 7 \\
F-Test & $* * *$ & $* * *$ & $*$ & $* *$ & $* * *$ & $* *$ & $* * *$ \\
\hline
\end{tabular}


Table 47: Grain yield ( $\left.\mathrm{tha}^{-1}\right)$ and uptake of $\mathrm{N}, \mathrm{P}, \mathrm{K}, \mathrm{Ca}, \mathrm{Mg}, \mathrm{Mn}$ and $\mathrm{Zn}\left(\mathrm{kg} \mathrm{ha}^{-1}\right)$ of maize grain as affected by different nutrient applications in the of minus-one trials. Locations: CH 1 and CH 2. Harvest of October 1995.

\begin{tabular}{lcrrrrrrr}
\hline Treatment & grain & $\mathrm{N}$ & $\mathrm{P}$ & $\mathrm{K}$ & $\mathrm{Ca}$ & $\mathrm{Mg}$ & $\mathrm{Mn}$ & $\mathrm{Zn}$ \\
\hline CH 1 (not degraded) & & & & & & & \\
All & 4.0 & 77 & 18 & 50 & 0.61 & 4 & 0.25 & 0.10 \\
All org & 4.7 & 86 & 21 & 61 & 1.38 & 6 & 0.28 & 0.13 \\
-N & 1.0 & 16 & 4 & 12 & 0.30 & 1 & 0.04 & 0.03 \\
-P & 3.0 & 53 & 10 & 33 & 0.86 & 3 & 0.20 & 0.11 \\
$-\mathrm{K}$ & 4.1 & 77 & 19 & 56 & 1.03 & 5 & 0.27 & 0.12 \\
-Ca/org & 2.5 & 39 & 9 & 27 & 0.69 & 2 & 0.14 & 0.06 \\
$-\mathrm{Mg}$ & 3.8 & 72 & 16 & 52 & 0.99 & 4 & 0.18 & 0.11 \\
$-\mathrm{S}$ & 4.2 & 77 & 19 & 52 & 0.90 & 5 & 0.27 & 0.13 \\
$-\mathrm{Mo} /-\mathrm{Zn}$ & 4.0 & 76 & 18 & 56 & 0.40 & 4 & 0.26 & 0.11 \\
None & 1.2 & 18 & 5 & 13 & 0.37 & 1 & 0.07 & 0.03 \\
Mean & 3.3 & 59 & 14 & 41 & 0.75 & 4 & 0.20 & 0.10 \\
LSD & 0.6 & 12 & 3 & 6 & 0.49 & 1 & 0.07 & 0.03 \\
$F-$ Test & $* * *$ & $* * *$ & $* * *$ & $* * *$ & $* * *$ & $* * *$ & $* * *$ & $* * *$
\end{tabular}

\section{CH 2 (degraded)}

\begin{tabular}{lrrrrrrrr} 
All & 3.8 & 66 & 18 & 48 & 2.49 & 5 & 0.26 & 0.09 \\
All org & 4.8 & 89 & 22 & 65 & 3.08 & 6 & 0.35 & 0.12 \\
$-\mathrm{N}$ & 0.6 & 8 & 2 & 7 & 0.39 & 1 & 0.03 & 0.01 \\
$-\mathrm{P}$ & 0.9 & 16 & 2 & 9 & 0.66 & 1 & 0.06 & 0.02 \\
$-\mathrm{K}$ & 3.6 & 65 & 15 & 48 & 2.55 & 5 & 0.27 & 0.09 \\
$-\mathrm{Ca} /$ org & 2.1 & 31 & 8 & 26 & 1.25 & 2 & 0.14 & 0.05 \\
$-\mathrm{Mg}$ & 3.7 & 66 & 17 & 49 & 2.54 & 5 & 0.22 & 0.09 \\
$-\mathrm{S}$ & 3.9 & 67 & 17 & 44 & 2.48 & 4 & 0.26 & 0.10 \\
$-\mathrm{Mo} /-\mathrm{Zn}$ & 3.9 & 68 & 18 & 55 & 2.69 & 5 & 0.27 & 0.10 \\
None & 0.5 & 7 & 2 & 6 & 0.36 & 1 & 0.04 & 0.01 \\
Mean & 2.8 & 48 & 12 & 36 & 1.85 & 3 & 0.19 & 0.07 \\
LSD & 0.5 & 10 & 4 & 11 & 0.50 & 1 & 0.07 & 0.04 \\
$F-$ Test & $* * *$ & $* * *$ & $* * *$ & $* * *$ & $* * *$ & $* * *$ & $* * *$ & $* * *$ \\
\hline
\end{tabular}


Table 48: Stover yield $\left(\mathrm{t} \mathrm{ha}^{-1}\right)$ and uptake of $\mathrm{N}, \mathrm{P}, \mathrm{K}, \mathrm{Ca}, \mathrm{Mg}, \mathrm{Mn}$ and $\mathrm{Zn}\left(\mathrm{kg} \mathrm{ha}^{-1}\right)$ of maize stover as affected by different nutrient application in the of minus-one trials. Locations: CH 1 and CH 2. Harvest of October 1995.

\begin{tabular}{|c|c|c|c|c|c|c|c|c|}
\hline Treatment & straw & $\mathrm{N}$ & $\mathrm{P}$ & $\mathrm{K}$ & $\mathrm{Ca}$ & $\mathrm{Mg}$ & $\mathrm{Mn}$ & $\mathrm{Zn}$ \\
\hline \multicolumn{9}{|c|}{ CH 1 (not degraded) } \\
\hline All & 3.6 & 24 & 2.4 & 77 & 3.0 & 3.0 & 0.10 & 0.06 \\
\hline All org & 4.3 & 30 & 3.0 & 117 & 3.8 & 3.7 & 0.12 & 0.06 \\
\hline$-\mathrm{N}$ & 1.4 & 6 & 2.3 & 24 & 0.9 & 1.3 & 0.04 & 0.03 \\
\hline$-\mathrm{P}$ & 2.9 & 24 & 1.7 & 60 & 2.7 & 3.1 & 0.08 & 0.08 \\
\hline$-K$ & 3.5 & 24 & 2.5 & 58 & 3.2 & 3.5 & 0.09 & 0.05 \\
\hline$-\mathrm{Ca} /$ org & 1.7 & 9 & 1.5 & 29 & 1.3 & 1.3 & 0.05 & 0.04 \\
\hline$-\mathrm{Mg}$ & 2.8 & 18 & 2.9 & 51 & 2.7 & 2.1 & 0.08 & 0.04 \\
\hline$-S$ & 4.1 & 27 & 3.6 & 88 & 3.6 & 3.4 & 0.12 & 0.05 \\
\hline$-\mathrm{Mo} /-\mathrm{Zn}$ & 3.9 & 27 & 3.2 & 84 & 3.6 & 3.1 & 0.09 & 0.05 \\
\hline None & 1.1 & 6 & 1.4 & 19 & 0.9 & 1.1 & 0.03 & 0.03 \\
\hline Mean & 2.9 & 20 & 2.5 & 61 & 2.6 & 2.6 & 0.08 & 0.05 \\
\hline LSD & 0.8 & 4.0 & 1.0 & 15 & 0.7 & 0.7 & 0.03 & 0.02 \\
\hline F-Test & $* * *$ & $* * *$ & $*$ & $* * *$ & $* * *$ & $* * *$ & $* * *$ & $* *$ \\
\hline
\end{tabular}

\section{CH 2 (degraded)}

\begin{tabular}{lrrrrrrrr} 
All & 3.4 & 22 & 2.3 & 51 & 2.9 & 2.8 & 0.48 & 0.06 \\
All org & 4.0 & 29 & 3.0 & 78 & 3.4 & 3.2 & 0.48 & 0.08 \\
-N & 0.9 & 5 & 1.6 & 12 & 0.5 & 0.8 & 0.11 & 0.02 \\
-P & 1.4 & 14 & 0.5 & 21 & 1.0 & 1.6 & 0.33 & 0.07 \\
-K & 3.0 & 24 & 1.9 & 32 & 2.9 & 3.8 & 0.45 & 0.08 \\
-Ca/org & 1.9 & 9 & 1.1 & 21 & 1.3 & 1.5 & 0.32 & 0.04 \\
-Mg & 3.7 & 26 & 2.3 & 54 & 3.6 & 2.8 & 0.70 & 0.06 \\
-S & 3.8 & 23 & 2.2 & 82 & 2.9 & 2.9 & 0.50 & 0.08 \\
-Mo/-Zn & 3.7 & 27 & 2.9 & 49 & 3.4 & 3.5 & 0.61 & 0.05 \\
None & 0.6 & 3 & 0.2 & 5 & 0.4 & 0.5 & 0.12 & 0.01 \\
Mean & 2.6 & 18 & 1.8 & 40 & 2.2 & 2.3 & 0.41 & 0.06 \\
LSD & 0.8 & 5 & 0.6 & 21 & 0.5 & 0.6 & 0.14 & 0.06 \\
F-Test & $* * *$ & $* * *$ & $* * *$ & $* * *$ & $* * *$ & $* * *$ & $* * *$ & $* * *$ \\
\hline
\end{tabular}


Table 49: Nutrient concentration in above ground spontaneous vegetation regrowth at the beginning of the third cropping cycle harvested in June 1995 at CH 1 and CH 2.

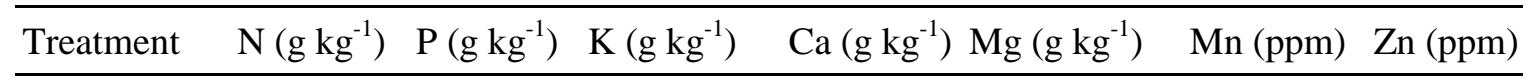

\section{CH 1 (not degraded)}

\begin{tabular}{|c|c|c|c|c|c|c|c|}
\hline All & 15 & 1.6 & 34.8 & 2.9 & 3.7 & 75.2 & 31.3 \\
\hline All org & 15 & 1.5 & 32.9 & 2.5 & 3.5 & 89.3 & 32.8 \\
\hline$-\mathrm{N}$ & 14 & 1.9 & 31.3 & 3.4 & 3.8 & 80.2 & 31.4 \\
\hline$-\mathrm{P}$ & 14 & 1.0 & 23.4 & 1.6 & 2.9 & 97.8 & 40.1 \\
\hline -Ca/org & 15 & 1.4 & 31.0 & 2.3 & 3.4 & 87.3 & 35.3 \\
\hline None & 16 & 1.5 & 33.8 & 3.5 & 4.0 & 83.8 & 35.6 \\
\hline Mean & 15 & 1.5 & 32.4 & 2.8 & 3.7 & 83.3 & 34.2 \\
\hline Stand. Dev. ${ }^{a}$ & 3 & 0.5 & 7.7 & 1.2 & 0.7 & 15.2 & 5.7 \\
\hline
\end{tabular}

\section{CH 2 (degraded)}

\begin{tabular}{lccccccc} 
All & 14 & 1.1 & 24.9 & 2.2 & 3.0 & 125.2 & 31.6 \\
All org & 16 & 1.2 & 26.9 & 3.0 & 3.2 & 100.8 & 27.6 \\
-N & 14 & 1.2 & 22.3 & 2.6 & 3.1 & 133.9 & 32.4 \\
-P & 16 & 0.9 & 22.9 & 3.2 & 3.3 & 108.8 & 31.4 \\
-Ca/org & 13 & 1.0 & 21.9 & 2.1 & 3.0 & 127.5 & 24.8 \\
None & 13 & 0.8 & 18.4 & 2.7 & 3.0 & 133.5 & 28.8 \\
Mean & 14 & 1.0 & 22.5 & 2.5 & 3.1 & 123.7 & 29.5 \\
Stand. Dev. & 3 & 0.2 & 7.1 & 1.1 & 0.6 & 31.2 & 8.1 \\
\hline
\end{tabular}

${ }^{\mathrm{a}}$ Standard deviation

Table 50: Biomass yield $\left(\mathrm{t} \mathrm{ha}^{-1}\right)$ and uptake of $\mathrm{N}, \mathrm{P}, \mathrm{K}, \mathrm{Ca}, \mathrm{Mg}, \mathrm{Mn}$ and $\mathrm{Zn}\left(\mathrm{kg} \mathrm{ha}^{-1}\right)$ by above ground spontaneous vegetation regrowth harvested in June 1995 at CH 1 and CH 2.

\begin{tabular}{lcccccccc}
\hline Treatment & biomass yield & $\mathrm{N}$ & $\mathrm{P}$ & $\mathrm{K}$ & $\mathrm{Ca}$ & $\mathrm{Mg}$ & $\mathrm{Mn}$ & $\mathrm{Zn}$ \\
\hline CH 1 (not degraded) & & & & & & & & \\
All & 3.5 & 1.5 & 1.6 & 34.8 & 2.9 & 3.7 & 75.2 & 31.3 \\
All org & 4.1 & 1.5 & 1.5 & 32.9 & 2.5 & 3.5 & 89.3 & 32.8 \\
-N & 2.5 & 1.4 & 1.9 & 31.3 & 3.4 & 3.8 & 80.2 & 31.4 \\
-P & 3.0 & 1.3 & 1.0 & 23.4 & 1.6 & 2.9 & 97.8 & 40.1 \\
-Ca/org & 3.3 & 1.5 & 1.4 & 31.0 & 2.3 & 3.4 & 87.3 & 35.3 \\
None & 2.1 & 1.6 & 1.5 & 33.8 & 3.5 & 4.0 & 83.8 & 35.6 \\
Mean & 3.0 & 1.5 & 1.5 & 32.4 & 2.8 & 3.7 & 83.3 & 34.2 \\
Stand. Dev. & 1.0 & 0.3 & 0.5 & 7.7 & 1.2 & 0.7 & 15.2 & 5.7 \\
CH 2 (degraded) & & & & & & & & \\
All & 3.2 & 1.4 & 1.1 & 24.9 & 2.2 & 3.0 & 125.2 & 31.6 \\
All org & 3.3 & 1.6 & 1.2 & 26.9 & 3.0 & 3.2 & 100.8 & 27.6 \\
-N & 2.2 & 1.4 & 1.2 & 22.3 & 2.6 & 3.1 & 133.9 & 32.4 \\
-P & 2.4 & 1.6 & 0.9 & 22.9 & 3.2 & 3.3 & 108.8 & 31.4 \\
-Ca/org & 3.1 & 1.3 & 1.0 & 21.9 & 2.1 & 3.0 & 127.5 & 24.8 \\
None & 2.1 & 1.3 & 0.8 & 18.4 & 2.7 & 3.0 & 133.5 & 28.8 \\
Mean & 2.7 & 1.4 & 1.0 & 22.5 & 2.5 & 3.1 & 123.7 & 29.5 \\
Stand. Dev. & 1.0 & 0.3 & 0.2 & 7.1 & 1.1 & 0.6 & 31.2 & 8.1 \\
\hline
\end{tabular}


Table 51: Dynamics of base saturation (\%) in the $0-30 \mathrm{~cm}$ soil layer from June 1993 to October 1995 in the minus-one trials. Locations: CH 1, CH 2.

\begin{tabular}{|c|c|c|c|c|c|c|}
\hline \multicolumn{7}{|c|}{ Sampling date } \\
\hline Treatment & $06 / 93$ & $10 / 93$ & $06 / 94$ & $10 / 94$ & $06 / 95$ & $10 / 95$ \\
\hline \multicolumn{7}{|c|}{ CH 1 (non-degraded) } \\
\hline All & 83 & 76 & 79 & 77 & 65 & 71 \\
\hline All org & 77 & 79 & 83 & 76 & 65 & 67 \\
\hline$-\mathrm{N}$ & 78 & 82 & 83 & 81 & 71 & 77 \\
\hline$-\mathrm{P}$ & 81 & 81 & 81 & 78 & 68 & 70 \\
\hline$-\mathrm{K}$ & 83 & 82 & 82 & 79 & 69 & 73 \\
\hline -Ca/org & 84 & 73 & 80 & 80 & 65 & 71 \\
\hline$-\mathrm{Mg}$ & 82 & 81 & 82 & 77 & 67 & 70 \\
\hline$-S$ & 76 & 82 & 82 & 79 & 71 & 69 \\
\hline$-\mathrm{Mo} /-\mathrm{Zn}$ & 82 & 77 & 78 & 74 & 66 & 71 \\
\hline none & 81 & 84 & 79 & 78 & 69 & 78 \\
\hline $\operatorname{LSD}(0.05)$ & ns & ns & ns & ns & ns & $\mathrm{ns}$ \\
\hline Mean & 80 & 80 & 81 & 78 & 68 & 72 \\
\hline${ }^{\mathrm{a}} \mathrm{LSD}(0.05)$ & 3 & & & & & \\
\hline \multicolumn{7}{|c|}{ CH 2 (degraded) } \\
\hline All & 79 & 75 & 74 & 60 & 60 & 53 \\
\hline All org & 82 & 68 & 72 & 58 & 60 & 48 \\
\hline$-\mathrm{N}$ & 80 & 74 & 70 & 61 & 63 & 61 \\
\hline$-\mathrm{P}$ & 82 & 68 & 70 & 55 & 60 & 45 \\
\hline$-K$ & 81 & 75 & 73 & 57 & 60 & 54 \\
\hline -Ca/org & 78 & 66 & 70 & 60 & 60 & 51 \\
\hline$-\mathrm{Mg}$ & 81 & 68 & 69 & 56 & 60 & 49 \\
\hline$-S$ & 82 & 75 & 69 & 58 & 58 & 46 \\
\hline$-\mathrm{Mo} /-\mathrm{Zn}$ & 79 & 75 & 72 & 58 & 59 & 52 \\
\hline none & 82 & 72 & 73 & 55 & 59 & 61 \\
\hline LSD (0.05) & ns & $7 *$ & ns & ns & ns & 5 \\
\hline Mean & 81 & 72 & 71 & 58 & 60 & 52 \\
\hline${ }^{\mathrm{a}} \mathrm{LSD}(0.05)$ & 3 & & & & & \\
\hline
\end{tabular}

${ }^{a}$ LSD-test for significant differences of the sampling dates after 2-way ANOVA across pooled treatments. 
Table 52: Dynamics of extractable sulfate-S (ppm) in the $0-30 \mathrm{~cm}$ soil layer from June 1993 to October 1995 in the minus-one trials. Locations: CH 1, CH 2.

\begin{tabular}{|c|c|c|c|c|c|c|}
\hline & Sampl & & & & & \\
\hline Treatment & $06 / 93$ & $10 / 93$ & $06 / 94$ & $10 / 94$ & $06 / 95$ & $10 / 95$ \\
\hline & 11 (no & aded) & & & & \\
\hline All & 1.8 & 2.0 & 2.7 & 1.6 & 2.5 & 2.0 \\
\hline All org & 1.7 & 2.6 & 3.2 & 1.7 & 2.1 & 1.8 \\
\hline$-\mathrm{N}$ & 1.8 & 2.6 & 2.7 & 1.4 & 2.0 & 2.2 \\
\hline$-\mathrm{P}$ & 1.9 & 2.2 & 3.7 & 2.2 & 2.5 & 2.0 \\
\hline$-K$ & 1.7 & 2.3 & 2.6 & 1.6 & 2.3 & 1.8 \\
\hline -Ca/org & 1.7 & 2.3 & 2.7 & 1.7 & 2.2 & 1.9 \\
\hline$-\mathrm{Mg}$ & 1.9 & 2.2 & 2.7 & 1.8 & 2.0 & 1.8 \\
\hline$-S$ & 1.6 & 2.1 & 2.9 & 1.9 & 2.1 & 2.3 \\
\hline -Mo/-Zn & 1.8 & 2.0 & 2.5 & 2.1 & 1.9 & 1.7 \\
\hline none & 1.8 & 2.3 & 2.7 & 1.5 & 1.7 & 1.9 \\
\hline LSD (0.05) & ns & ns & ns & ns & $\mathrm{ns}$ & ns \\
\hline Mean & 1.8 & 2.3 & 2.8 & 1.8 & 2.1 & 1.9 \\
\hline${ }^{\mathrm{a}} \operatorname{LSD}(0.05)$ & 0.3 & & & & & \\
\hline & 2 (de & & & & & \\
\hline All & 1.4 & 2.7 & 1.5 & 1.8 & 1.3 & 2.3 \\
\hline All org & 1.5 & 2.6 & 1.5 & 1.9 & 1.5 & 2.1 \\
\hline$-\mathrm{N}$ & 1.5 & 2.2 & 1.4 & 1.6 & 0.9 & 2.0 \\
\hline$-\mathrm{P}$ & 1.3 & 3.2 & 1.5 & 1.7 & 1.2 & 1.9 \\
\hline$-\mathrm{K}$ & 1.3 & 2.5 & 1.6 & 1.8 & 1.3 & 2.2 \\
\hline -Ca/org & 1.4 & 2.4 & 1.4 & 1.7 & 1.2 & 2.1 \\
\hline$-\mathrm{Mg}$ & 1.4 & 2.4 & 1.5 & 1.8 & 1.4 & 2.3 \\
\hline$-S$ & 1.6 & 2.6 & 1.4 & 1.6 & 1.3 & 2.4 \\
\hline -Mo/-Zn & 1.3 & 2.4 & 1.5 & 1.7 & 1.2 & 2.7 \\
\hline none & 1.4 & 2.4 & 1.3 & 1.4 & 1.0 & 2.4 \\
\hline LSD (0.05) & ns & $\mathrm{ns}$ & ns & ns & $\mathrm{ns}$ & ns \\
\hline Mean & 1.4 & 2.5 & 1.4 & 1.7 & 1.2 & 2.2 \\
\hline${ }^{\mathrm{a}} \mathrm{LSD}(0.05)$ & 0.2 & & & & & \\
\hline
\end{tabular}

${ }^{a}$ LSD-test for significant differences of the sampling dates after 2-way ANOVA across pooled treatments. 
Table 53: Dynamics of exchangeable $\mathrm{Mn}(\mathrm{ppm})$ in the $0-30 \mathrm{~cm}$ soil layer from June 1993 to October 1995 in the minus-one trials. Locations: CH 1, CH 2.

\begin{tabular}{|c|c|c|c|c|c|c|}
\hline \multicolumn{7}{|c|}{ Sampling date } \\
\hline Treatment & $06 / 93$ & $10 / 93$ & $06 / 94$ & $10 / 94$ & $06 / 95$ & $10 / 95$ \\
\hline \multicolumn{7}{|c|}{ CH 1 (non-degraded) } \\
\hline All & 0.04 & 0.07 & 0.05 & 0.06 & 0.06 & 0.06 \\
\hline All org & 0.04 & 0.08 & 0.06 & 0.07 & 0.06 & 0.07 \\
\hline$-\mathrm{N}$ & 0.04 & 0.04 & 0.04 & 0.05 & 0.05 & 0.05 \\
\hline$-\mathrm{P}$ & 0.04 & 0.07 & 0.06 & 0.06 & 0.07 & 0.07 \\
\hline$-\mathrm{K}$ & 0.04 & 0.06 & 0.05 & 0.05 & 0.06 & 0.06 \\
\hline - $\mathrm{Ca} /$ org & 0.04 & 0.08 & 0.06 & 0.06 & 0.06 & 0.06 \\
\hline$-\mathrm{Mg}$ & 0.04 & 0.06 & 0.05 & 0.06 & 0.07 & 0.07 \\
\hline$-S$ & 0.05 & 0.07 & 0.07 & 0.07 & 0.08 & 0.07 \\
\hline$-\mathrm{Mo} /-\mathrm{Zn}$ & 0.04 & 0.07 & 0.05 & 0.06 & 0.07 & 0.07 \\
\hline none & 0.04 & 0.05 & 0.04 & 0.06 & 0.06 & 0.06 \\
\hline $\operatorname{LSD}(0.05)$ & ns & $\mathrm{ns}$ & ns & ns & $\mathrm{ns}$ & ns \\
\hline Mean & 0.04 & 0.07 & 0.05 & 0.06 & 0.06 & 0.06 \\
\hline${ }^{\mathrm{a}} \mathrm{LSD}(0.05)$ & 0.004 & & & & & \\
\hline \multicolumn{7}{|c|}{ CH 2 (degraded) } \\
\hline All & 0.09 & 0.07 & 0.09 & 0.08 & 0.08 & 0.08 \\
\hline All org & 0.07 & 0.09 & 0.09 & 0.07 & 0.08 & 0.08 \\
\hline$-\mathrm{N}$ & 0.07 & 0.07 & 0.08 & 0.07 & 0.08 & 0.07 \\
\hline$-\mathrm{P}$ & 0.07 & 0.10 & 0.09 & 0.08 & 0.09 & 0.08 \\
\hline$-K$ & 0.08 & 0.08 & 0.09 & 0.08 & 0.08 & 0.08 \\
\hline$-\mathrm{Ca} /$ org & 0.08 & 0.08 & 0.09 & 0.08 & 0.09 & 0.08 \\
\hline$-\mathrm{Mg}$ & 0.08 & 0.08 & 0.08 & 0.08 & 0.08 & 0.08 \\
\hline$-S$ & 0.08 & 0.08 & 0.09 & 0.08 & 0.08 & 0.07 \\
\hline$-\mathrm{Mo} /-\mathrm{Zn}$ & 0.08 & 0.08 & 0.08 & 0.07 & 0.07 & 0.07 \\
\hline none & 0.09 & 0.07 & 0.08 & 0.08 & 0.09 & 0.08 \\
\hline LSD (0.05) & ns & ns & ns & ns & ns & ns \\
\hline Mean & 0.08 & 0.08 & 0.09 & 0.08 & 0.08 & 0.08 \\
\hline${ }^{\mathrm{a}} \mathrm{LSD}(0.05)$ & 0.006 & & & & & \\
\hline
\end{tabular}

${ }^{\mathrm{a}}$ LSD-test for significant differences of the sampling dates after 2-way ANOVA across pooled treatments. 


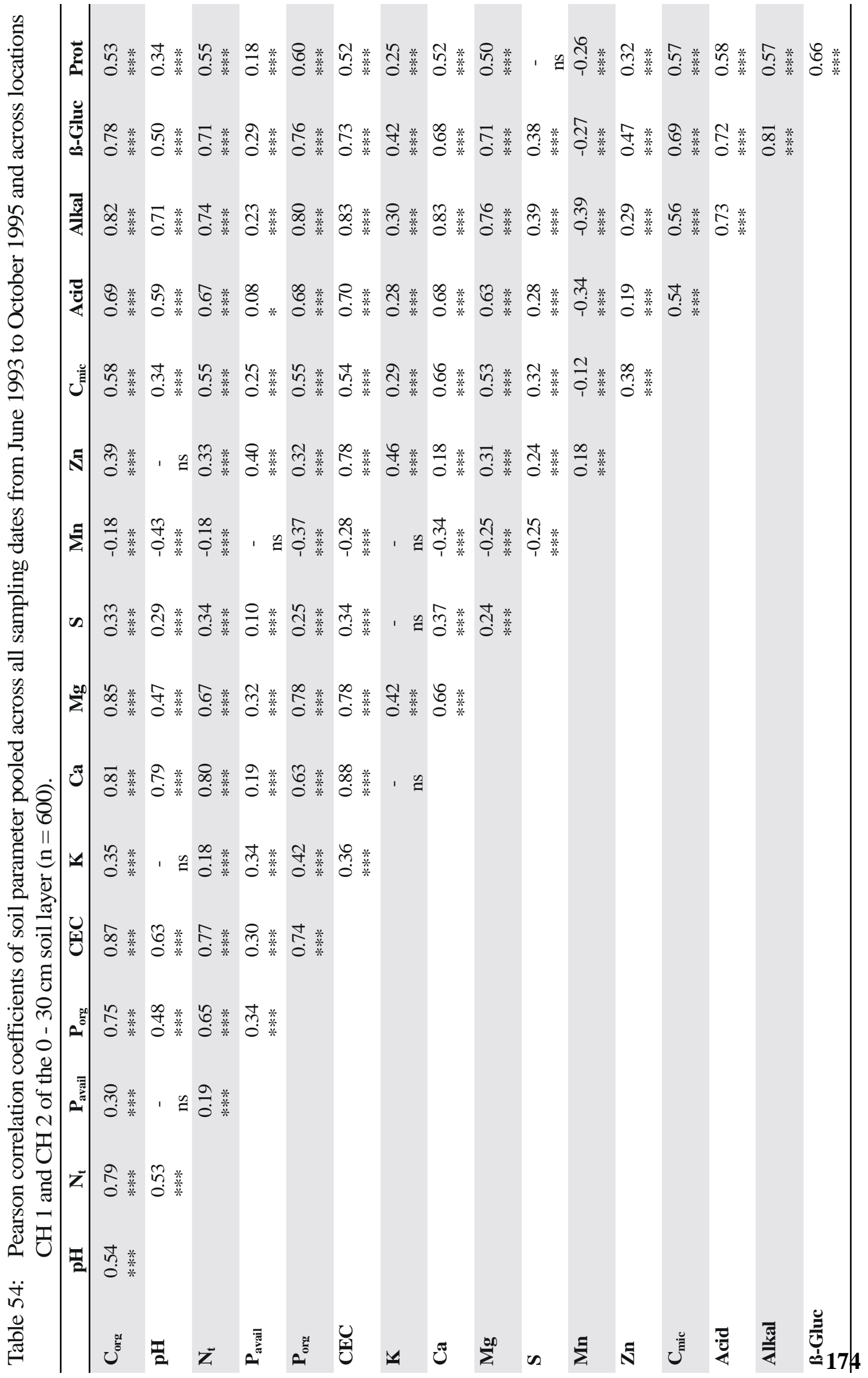


Table 55: Soil $\mathrm{NH}_{4}{ }^{+}$and $\mathrm{NO}_{3}{ }^{-}$content $\left(\mathrm{kg} \mathrm{ha}^{-1}\right)$ in the top soil $(0-30 \mathrm{~cm})$ at the beginning and at the end of the season during three years as affected by fertilization. Location: $\mathrm{CH} 1$ and $\mathrm{CH} 2$.

\begin{tabular}{|c|c|c|c|c|c|c|}
\hline \multicolumn{7}{|c|}{ Sampling Date } \\
\hline Treatment & 06.93 & 10.93 & 06.94 & 10.94 & 06.95 & 10.95 \\
\hline \multicolumn{7}{|c|}{$\mathrm{NH}_{4}{ }^{+}$content, $\mathrm{CH} 1$ (not degraded) } \\
\hline All & 22 & 17 & 10 & 11 & 7 & 5 \\
\hline All org & 26 & 19 & 11 & 12 & 6 & 5 \\
\hline$-\mathrm{N}$ & 26 & 14 & 8 & 5 & 4 & 4 \\
\hline$-\mathrm{Ca} /$ org $^{+}$ & 24 & 19 & 10 & 10 & 5 & 4 \\
\hline none & 28 & 21 & 7 & 6 & 4 & 4 \\
\hline Mean & 25 & 18 & 9 & 9 & 5 & 4 \\
\hline LSD & 5 & 7 & 4 & 2 & 2 & 3 \\
\hline F-Test & ns & ns & $\mathrm{ns}$ & $* * *$ & $*$ & $\mathrm{~ns}$ \\
\hline
\end{tabular}

$\mathrm{NH}_{4}{ }^{+}$content, $\mathrm{CH} 2$ (degraded)

\begin{tabular}{lcccccc} 
All & 4 & 10 & 8 & 9 & 6 & 4 \\
All org & 3 & 9 & 8 & 10 & 6 & 5 \\
-N & 4 & 7 & 5 & 8 & 5 & 1 \\
-Ca/org & 3 & 10 & 8 & 9 & 4 & 3 \\
none & 3 & 6 & 6 & 7 & 4 & 1 \\
Mean & 4 & 8 & 7 & 9 & 5 & 3 \\
LSD & 3 & 5 & 4 & 6 & 1 & 1 \\
$F-T e s t$ & $\mathrm{~ns}$ & $\mathrm{~ns}$ & $\mathrm{~ns}$ & $\mathrm{~ns}$ & $* *$ & $* * *$ \\
\hline
\end{tabular}

$\mathrm{NO}_{3}{ }^{-}$content, $\mathrm{CH} 1$ (not degraded)

$\begin{array}{lcccccc}\text { All } & 11 & 36 & 34 & 43 & 74 & 55 \\ \text { All org } & 13 & 38 & 40 & 70 & 81 & 78 \\ \text {-N } & 13 & 19 & 19 & 25 & 47 & 25 \\ \text {-Ca/org } & 11 & 41 & 29 & 42 & 52 & 45 \\ \text { none } & 13 & 27 & 32 & 26 & 44 & 26 \\ \text { Mean } & 12 & 32 & 31 & 41 & 59 & 46 \\ \text { LSD } & 5 & 16 & 19 & 13 & 10 & 13 \\ \text { F-Test } & \mathrm{ns} & 0.06 & \mathrm{~ns} & * * * & * * * & * * *\end{array}$

$\mathrm{NO}_{3}{ }^{-}$content, $\mathrm{CH} 2$ (degraded)

\begin{tabular}{|c|c|c|c|c|c|c|}
\hline All & 18 & 48 & 56 & 60 & 66 & 40 \\
\hline All org & 22 & 48 & 63 & 65 & 71 & 53 \\
\hline$-\mathrm{N}$ & 25 & 27 & 39 & 53 & 60 & 15 \\
\hline$-\mathrm{Ca} /$ org $^{+}$ & 18 & 49 & 49 & 58 & 62 & 31 \\
\hline none & 19 & 27 & 44 & 51 & 59 & 13 \\
\hline Mean & 20 & 40 & 50 & 58 & 64 & 30 \\
\hline LSD & 12 & 22 & 28 & 7 & 6 & 7 \\
\hline F-Test & $\mathrm{ns}$ & 0.08 & $\mathrm{~ns}$ & $* *$ & $* *$ & $* * *$ \\
\hline
\end{tabular}


Table 56: Soil mineral $\left(\mathrm{N}_{\min }\right)$ content $\left(\mathrm{kg} \mathrm{ha}^{-1}\right)$ in the top soil $(0-30 \mathrm{~cm})$ at the beginning and at the end of the season during three years as affected by fertilization. Location: $\mathrm{CH} 1$ and $\mathrm{CH} 2$.

\begin{tabular}{|c|c|c|c|c|c|c|}
\hline \multirow[b]{2}{*}{ Treatment } & \multicolumn{6}{|c|}{ Sampling Date } \\
\hline & 06.93 & 10.93 & 06.94 & 10.94 & 06.95 & 10.95 \\
\hline \multicolumn{7}{|c|}{ CH 1 (not degraded) } \\
\hline All & 33 & 53 & 44 & 54 & 80 & 60 \\
\hline All org & 38 & 57 & 51 & 82 & 86 & 83 \\
\hline$-\mathrm{N}$ & 39 & 33 & 27 & 30 & 51 & 29 \\
\hline$-\mathrm{Ca} /$ org $^{+}$ & 36 & 59 & 39 & 52 & 57 & 49 \\
\hline none & 41 & 48 & 39 & 32 & 48 & 29 \\
\hline Mean & 37 & 50 & 40 & 50 & 64 & 50 \\
\hline LSD & 7 & 19 & 19 & 14 & 10 & 13 \\
\hline F-Test & ns & 0.06 & ns & $* * *$ & $* * *$ & $* * *$ \\
\hline
\end{tabular}

\section{CH 2 (degraded)}

\begin{tabular}{|c|c|c|c|c|c|c|}
\hline All & 23 & 58 & 64 & 70 & 72 & 43 \\
\hline All org & 25 & 58 & 71 & 75 & 77 & 58 \\
\hline$-\mathrm{N}$ & 29 & 34 & 44 & 60 & 65 & 17 \\
\hline$-\mathrm{Ca} /$ org $^{+}$ & 21 & 58 & 56 & 68 & 67 & 33 \\
\hline none & 21 & 33 & 50 & 58 & 62 & 15 \\
\hline Mean & 24 & 48 & 57 & 66 & 69 & 33 \\
\hline LSD & 13 & 25 & 28 & 11 & 6 & 7 \\
\hline F-Test & $\mathrm{ns}$ & 0.08 & ns & $*$ & $* * *$ & $* * *$ \\
\hline
\end{tabular}


Table 57: Soil ammonium content $\left(\mathrm{kg} \mathrm{ha}^{-1}\right)$ under maize from June 1995 to October 1995 in soil layers of $0-30 \mathrm{~cm}, 30-60 \mathrm{~cm}, 60-90 \mathrm{~cm}$ as affected by fertilizer applications. Location $\mathrm{CH} 1$ (not degraded).

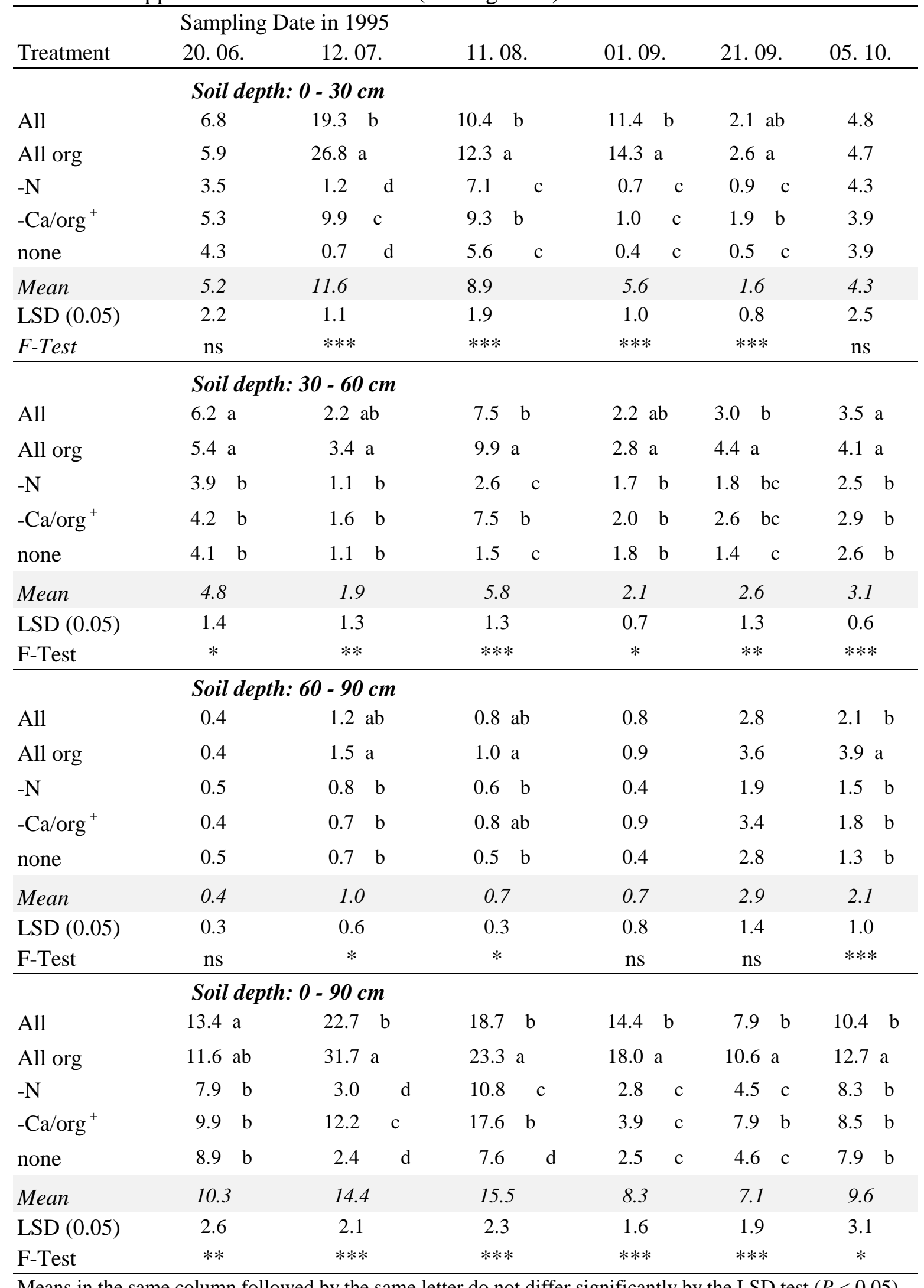

Means in the same column followed by the same letter do not differ significantly by the LSD test $(P<0.05)$. 
Table 58: Soil ammonium content $\left(\mathrm{kg} \mathrm{ha}^{-1}\right)$ under maize from June 1995 to October 1995 in soil layers of $0-30 \mathrm{~cm}, 30-60 \mathrm{~cm}, 60-90 \mathrm{~cm}$ as affected by fertilizer applications. Location $\mathrm{CH} 2$ (degraded).

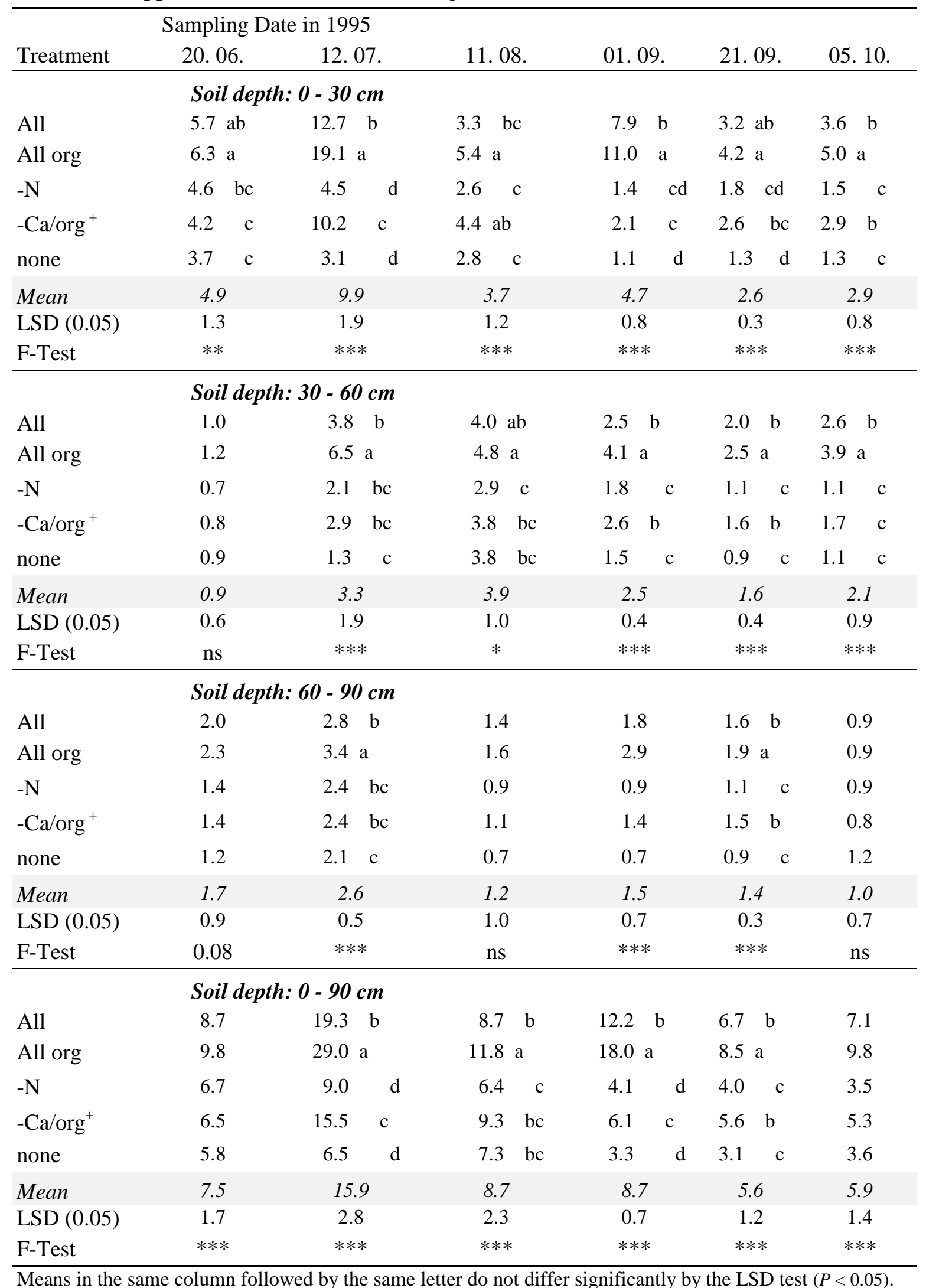


Table 59: Soil nitrate content $\left(\mathrm{kg} \mathrm{ha}^{-1}\right)$ under maize from June 1995 to October 1995 in soil layers of $0-30 \mathrm{~cm}, 30-60 \mathrm{~cm}, 60-90 \mathrm{~cm}$ as affected by fertilizer applications. Location $\mathrm{CH} 1$ (not degraded).

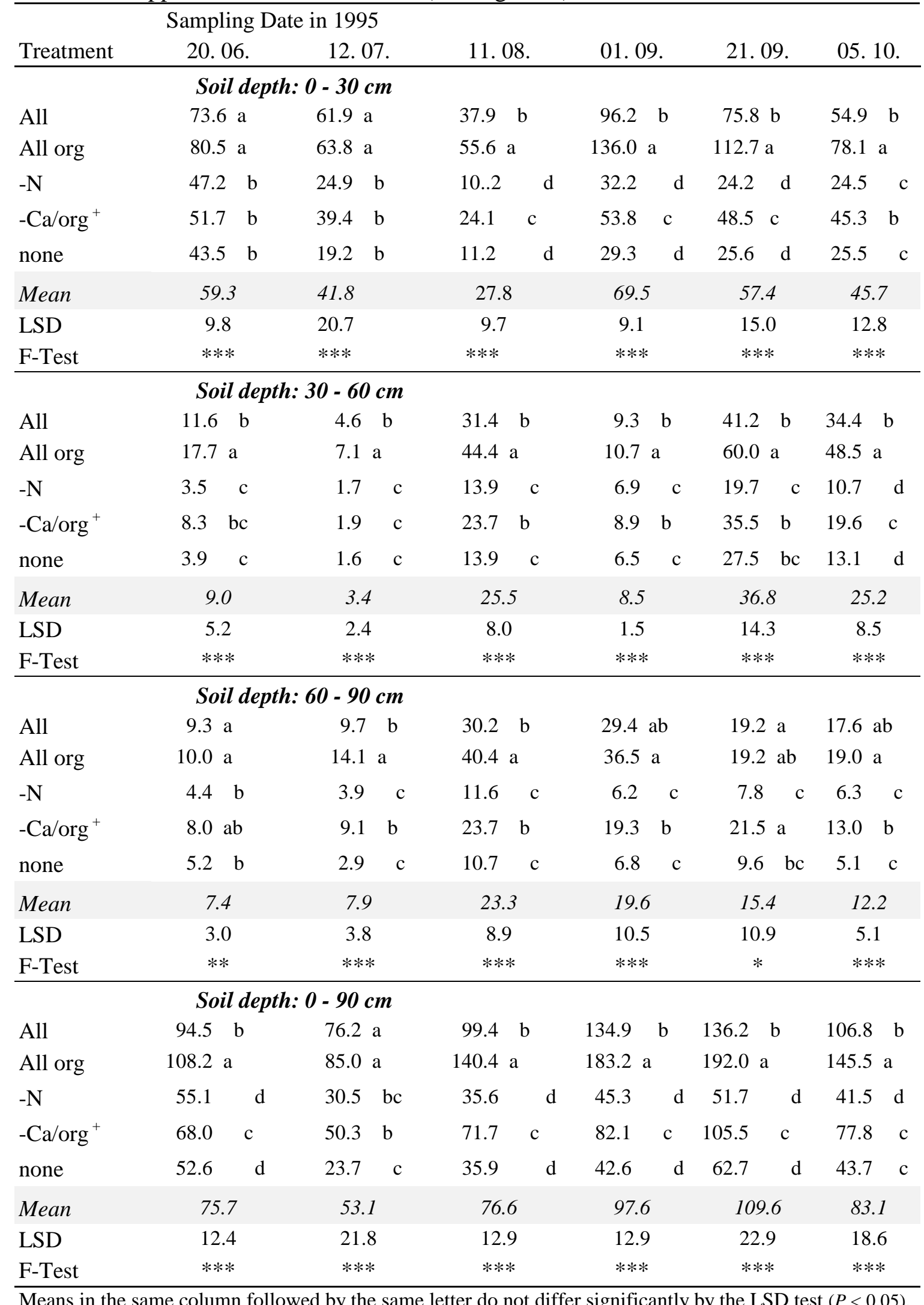

Means in the same column followed by the same letter do not differ significantly by the LSD test $(P<0.05)$. 
Table 60: Soil nitrate content $\left(\mathrm{kg} \mathrm{ha}^{-1}\right)$ under maize from June 1995 to October 1995 in soil layers of $0-30 \mathrm{~cm}, 30-60 \mathrm{~cm}, 60-90 \mathrm{~cm}$ as affected by fertilizer applications. Location CH 2 (degraded).

Sampling Date in 1995

\begin{tabular}{|c|c|c|c|c|c|c|}
\hline Treatment & 20.06. & 12.07. & 11.08. & 01.09. & 21.09. & 05.10. \\
\hline \multicolumn{7}{|c|}{ Soil depth: $0-30 \mathrm{~cm}$} \\
\hline All & $66.2 \mathrm{ab}$ & 74.5 a & $41.9 \mathrm{ab}$ & 80.9 a & $57.0 \quad \mathrm{~b}$ & $39.8 \mathrm{~b}$ \\
\hline All org & 70.8 a & $83.2 \mathrm{a}$ & $63.1 \mathrm{a}$ & 94.9 a & 88.6 a & $52.6 \mathrm{a}$ \\
\hline$-\mathrm{N}$ & $60.4 \quad c$ & $18.8 \mathrm{~b}$ & $13.5 \mathrm{c}$ & $29.6 \mathrm{~b}$ & 19.6 & $15.1 \mathrm{~d}$ \\
\hline$-\mathrm{Ca} /$ org $^{+}$ & $62.3 \mathrm{bc}$ & $62.1 \mathrm{a}$ & $30.0 \mathrm{bc}$ & $43.7 \quad b$ & 30.4 & $30.6 \mathrm{c}$ \\
\hline none & $58.7 \quad \mathrm{c}$ & $29.9 \mathrm{~b}$ & $16.8 \quad \mathrm{c}$ & $25.5 \mathrm{~b}$ & 19.5 & $13.4 \mathrm{~d}$ \\
\hline Mean & 63.7 & 53.7 & 33.0 & 54.9 & 43.1 & 30.3 \\
\hline LSD & 5.5 & 23.1 & 21.7 & 27.9 & 15.6 & 6.6 \\
\hline F-Test & $* *$ & $* * *$ & $* * *$ & $* * *$ & $* * *$ & $* * *$ \\
\hline \multicolumn{7}{|c|}{ Soil depth: $30-60 \mathrm{~cm}$} \\
\hline All & $36.7 \quad b$ & $36.9 \quad \mathrm{~b}$ & $19.2 \mathrm{a}$ & $24.0 \mathrm{~b}$ & $34.6 \mathrm{~b}$ & $23.3 \mathrm{~b}$ \\
\hline All org & $41.3 \mathrm{a}$ & 44.9 a & $24.6 \mathrm{a}$ & 32.9 a & 45.9 a & $39.1 \mathrm{a}$ \\
\hline$-\mathrm{N}$ & $26.5 \mathrm{~d}$ & $9.2 \mathrm{~d}$ & $7.7 \mathrm{~b}$ & $10.5 \mathrm{~d}$ & 13.2 & $7.9 \quad \mathrm{~d}$ \\
\hline$-\mathrm{Ca} /$ org $^{+}$ & $33.2 \quad \mathrm{c}$ & 19.8 & $11.5 \mathrm{~b}$ & $17.1 \quad \mathrm{c}$ & 25.6 & $14.0 \mathrm{c}$ \\
\hline none & 26.7 & 10.3 & $7.9 \mathrm{~b}$ & $15.1 \mathrm{~cd}$ & 13.6 & $8.7 \mathrm{~d}$ \\
\hline Mean & 32.9 & 24.2 & 14.2 & 19.9 & 26.6 & 18.6 \\
\hline LSD & 3.5 & 7.9 & 6.1 & 5.5 & 8.8 & 5.5 \\
\hline F-Test & $* * *$ & $* * *$ & $* * *$ & $* * *$ & $* * *$ & $* * *$ \\
\hline \multicolumn{7}{|c|}{ Soil depth: $60-90 \mathrm{~cm}$} \\
\hline All & $14.6 \mathrm{ab}$ & $24.3 \mathrm{ab}$ & $26.1 \mathrm{a}$ & $13.2 \mathrm{~b}$ & $26.4 \mathrm{~b}$ & $18.6 \mathrm{a}$ \\
\hline All org & 19.8 a & $31.4 \mathrm{a}$ & 32.9 a & $24.4 \mathrm{a}$ & $33.7 \mathrm{a}$ & $23.5 \mathrm{a}$ \\
\hline$-\mathrm{N}$ & $5.5 \mathrm{c}$ & $11.2 \mathrm{bc}$ & $13.3 \mathrm{~b}$ & $3.1 \quad \mathrm{c}$ & $8.5 \mathrm{~cd}$ & $5.2 \mathrm{~b}$ \\
\hline$-\mathrm{Ca} / \mathrm{org}^{+}$ & $8.0 \mathrm{bc}$ & $18.9 \mathrm{~b}$ & 25.9 a & 5.5 & $13.4 \mathrm{c}$ & 8.9 \\
\hline none & 5.9 & 8.6 & $14.9 \mathrm{~b}$ & 2.7 & $7.5 \mathrm{~d}$ & $5.8 \mathrm{~b}$ \\
\hline Mean & 10.8 & 18.9 & 22.6 & 9.8 & 17.9 & 12.4 \\
\hline LSD & 6.9 & 8.4 & 9.0 & 6.7 & 5.2 & 5.4 \\
\hline F-Test & $* * *$ & $* * *$ & $* * *$ & $* * *$ & $* * *$ & $* * *$ \\
\hline \multicolumn{7}{|c|}{ Soil depth: 0 - $90 \mathrm{~cm}$} \\
\hline All & $117.6 \quad b$ & $135.7 \quad b$ & 87.2 b & $118.0 \quad b$ & $118.1 \mathrm{~b}$ & $81.6 \quad b$ \\
\hline All org & $132.0 \mathrm{a}$ & $159.5 \mathrm{a}$ & 120.6 a & $152.2 \mathrm{a}$ & 168.2 a & $115.2 \mathrm{a}$ \\
\hline$-\mathrm{N}$ & $92.4 \quad \mathrm{~d}$ & $39.2 \quad \mathrm{~d}$ & 34.4 & $43.1 \quad \mathrm{c}$ & 41.3 & 28.1 \\
\hline$-\mathrm{Ca} / \mathrm{org}^{+}$ & $103.5 \mathrm{c}$ & 100.8 & 67.4 & 66.3 & 69.4 & 53.5 \\
\hline none & $91.2 \quad \mathrm{~d}$ & 48.9 & 39.6 & 43.2 & 40.6 & 27.9 \\
\hline Mean & 107.3 & 96.8 & 69.8 & 84.6 & 87.5 & 61.3 \\
\hline LSD & 9.1 & 23.4 & 20.0 & 27.9 & 24.8 & 11.3 \\
\hline F-Test & $* * *$ & $* * *$ & $* * *$ & $* * *$ & $* * *$ & $* * *$ \\
\hline
\end{tabular}

Means in the same column followed by the same letter do not differ significantly by the LSD test $(P<0.05)$. 
Table 61: Soil mineral N content $\left(\mathrm{kg} \mathrm{ha}^{-1}\right)$ under maize from June 1995 to October 1995 in soil layers of $0-30 \mathrm{~cm}, 30-60 \mathrm{~cm}, 60-90 \mathrm{~cm}$ as affected by fertilizer applications. Location $\mathrm{CH} 1$ (not degraded).

\begin{tabular}{|c|c|c|c|c|c|c|c|c|c|}
\hline \multirow[b]{2}{*}{ Treatment } & \multicolumn{9}{|c|}{ Sampling Date in 1995} \\
\hline & 20.06. & 12.07 & & 11.08. & & 01.09 & & 21.09. & 05.10. \\
\hline \multicolumn{10}{|c|}{ Soil depth: $0-30 \mathrm{~cm}$} \\
\hline All & $80.5 \mathrm{a}$ & $81.2 \mathrm{a}$ & & $48.2 \mathrm{~b}$ & & 107.7 & & $77.9 \quad b$ & $59.7 \mathrm{~b}$ \\
\hline All org & $86.5 \mathrm{a}$ & 90.7 a & & 67.9 a & & $150.3 \mathrm{a}$ & & $115.4 \mathrm{a}$ & 82.7 a \\
\hline$-\mathrm{N}$ & $50.7 \mathrm{~b}$ & 26.1 & & 17.2 & & 32.8 & $\mathrm{~d}$ & $25.1 \quad \mathrm{~d}$ & $28.8 \mathrm{c}$ \\
\hline$-\mathrm{Ca} / \mathrm{org}^{+}$ & $57.0 \mathrm{~b}$ & $49.3 \mathrm{~b}$ & & 33.3 & $\mathrm{c}$ & 54.8 & $\mathrm{c}$ & $50.4 \quad \mathrm{c}$ & $49.2 \mathrm{~b}$ \\
\hline none & $47.9 \mathrm{~b}$ & 19.8 & & 16.8 & & 29.7 & & $26.1 \quad \mathrm{~d}$ & $29.4 \quad c$ \\
\hline Mean & 64.5 & 53.4 & & 36.7 & & 75.1 & & 59.0 & 49.9 \\
\hline LSD & 10.4 & 20.3 & & 9.7 & & 9.1 & & 15.2 & 28.0 \\
\hline F-Test & $* * *$ & $* * *$ & & $* * *$ & & $* * *$ & & $* * *$ & $* * *$ \\
\hline \multicolumn{10}{|c|}{ Soil depth: $30-60 \mathrm{~cm}$} \\
\hline All & $17.7 \mathrm{ab}$ & $6.9 \mathrm{~b}$ & & $38.9 \mathrm{~b}$ & & 11.5 & & $44.2 \mathrm{~b}$ & $37.9 \mathrm{~b}$ \\
\hline All org & $23.1 \mathrm{a}$ & $10.4 \mathrm{a}$ & & $54.3 \mathrm{a}$ & & $13.4 \mathrm{a}$ & & $64.4 \mathrm{a}$ & $52.6 \mathrm{a}$ \\
\hline$-\mathrm{N}$ & $7.3 \quad \mathrm{c}$ & 2.8 & $\mathrm{c}$ & 16.4 & & 8.6 & $\mathrm{c}$ & $21.5 \quad \mathrm{~d}$ & $13.2 \mathrm{~d}$ \\
\hline$-\mathrm{Ca} /$ org $^{+}$ & $12.6 \mathrm{bc}$ & 3.5 & $\mathrm{c}$ & $31.3 \mathrm{~b}$ & & 10.9 & $\mathrm{~b}$ & $38.1 \mathrm{bc}$ & 22.4 \\
\hline none & $8.0 \quad \mathrm{c}$ & 2.7 & $\mathrm{c}$ & 15.4 & $\mathrm{c}$ & 8.3 & $\mathrm{c}$ & $28.9 \quad \mathrm{~cd}$ & $15.7 \mathrm{~cd}$ \\
\hline Mean & 13.8 & 5.2 & & 31.3 & & 10.5 & & 39.4 & 28.4 \\
\hline LSD & 6.2 & 2.9 & & 8.4 & & 1.6 & & 6.5 & 8.5 \\
\hline F-Test & $* * *$ & $* * *$ & & $* * *$ & & $* * *$ & & $* * *$ & $* * *$ \\
\hline \multicolumn{10}{|c|}{ Soil depth: $60-90 \mathrm{~cm}$} \\
\hline All & $9.7 \mathrm{a}$ & 10.9 & $\mathrm{~b}$ & $30.9 \mathrm{~b}$ & & $30.2 \mathrm{a}$ & & $22.0 \mathrm{a}$ & $9.7 \mathrm{ab}$ \\
\hline All org & $10.3 \mathrm{a}$ & 15.6 & & $41.5 \mathrm{a}$ & & $37.5 \mathrm{a}$ & & $22.8 \mathrm{a}$ & 22.9 a \\
\hline$-\mathrm{N}$ & $4.9 \quad \mathrm{c}$ & 4.6 & $\mathrm{c}$ & 12.2 & $\mathrm{c}$ & 6.7 & $\mathrm{c}$ & $9.6 \mathrm{~b}$ & $7.8 \quad \mathrm{c}$ \\
\hline$-\mathrm{Ca} / \mathrm{org}^{+}$ & $8.4 \mathrm{ab}$ & 9.8 & $\mathrm{~b}$ & $24.7 \mathrm{~b}$ & & 20.2 & $\mathrm{~b}$ & 24.9 a & $14.8 \mathrm{~b}$ \\
\hline none & $5.7 \mathrm{bc}$ & 3.5 & $\mathrm{c}$ & 11.2 & $\mathrm{c}$ & 7.1 & & $12.3 \mathrm{~b}$ & $6.4 \mathrm{c}$ \\
\hline Mean & 7.8 & 8.9 & & 24.1 & & 20.3 & & 18.3 & 14.3 \\
\hline LSD & 3.0 & 3.8 & & 8.8 & & 10.7 & & 5.7 & 5.3 \\
\hline F-Test & $* *$ & *** & & $* * *$ & & $* * *$ & & $*$ & $* * *$ \\
\hline \multicolumn{10}{|c|}{ Soil depth: 0 - $90 \mathrm{~cm}$} \\
\hline All & $107.9 \mathrm{~b}$ & 98.9 & $\mathrm{a}$ & 118.1 & $\mathrm{~b}$ & 149.4 & $\mathrm{~b}$ & $144.1 \mathrm{~b}$ & $117.3 \mathrm{~b}$ \\
\hline All org & 119.9 a & 116.7 & $\mathrm{a}$ & $163.6 \mathrm{a}$ & & $201.1 \mathrm{a}$ & & $202.5 \mathrm{a}$ & $158.2 \mathrm{a}$ \\
\hline$-\mathrm{N}$ & $62.9 \quad \mathrm{~d}$ & 33.5 & $\mathrm{c}$ & 45.8 & $\mathrm{~d}$ & 48.1 & $\mathrm{~d}$ & $56.2 \quad \mathrm{~d}$ & $49.7 \quad \mathrm{~d}$ \\
\hline$-\mathrm{Ca} /$ org $^{+}$ & $77.9 \quad \mathrm{c}$ & 62.5 & $\mathrm{~b}$ & 89.3 & $\mathrm{c}$ & 86.0 & $\mathrm{c}$ & $113.4 \mathrm{c}$ & $86.3 \mathrm{c}$ \\
\hline none & 61.6 & 26.0 & $\mathrm{c}$ & 43.1 & $\mathrm{~d}$ & 45.0 & $\mathrm{~d}$ & $67.4 \quad \mathrm{~d}$ & $51.6 \quad \mathrm{~d}$ \\
\hline Mean & 86.0 & 67.5 & & 92.0 & & 105.9 & & 116.7 & 92.6 \\
\hline LSD & 13.8 & 21.1 & & 13.1 & & 6.0 & & 22.5 & 18.3 \\
\hline F-Test & $* * *$ & $* * *$ & & $* * *$ & & $* * *$ & & $* * *$ & $* * *$ \\
\hline
\end{tabular}

Means in the same column followed by the same letter do not differ significantly by the LSD test $(P<0.05)$. 
Table 62: Soil mineral $\mathrm{N}$ content $\left(\mathrm{kg} \mathrm{ha}^{-1}\right)$ under maize from June 1995 to October 1995 in soil layers of $0-30 \mathrm{~cm}, 30-60 \mathrm{~cm}, 60-90 \mathrm{~cm}$ as affected by fertilizer applications. Location $\mathrm{CH} 2$ (degraded).

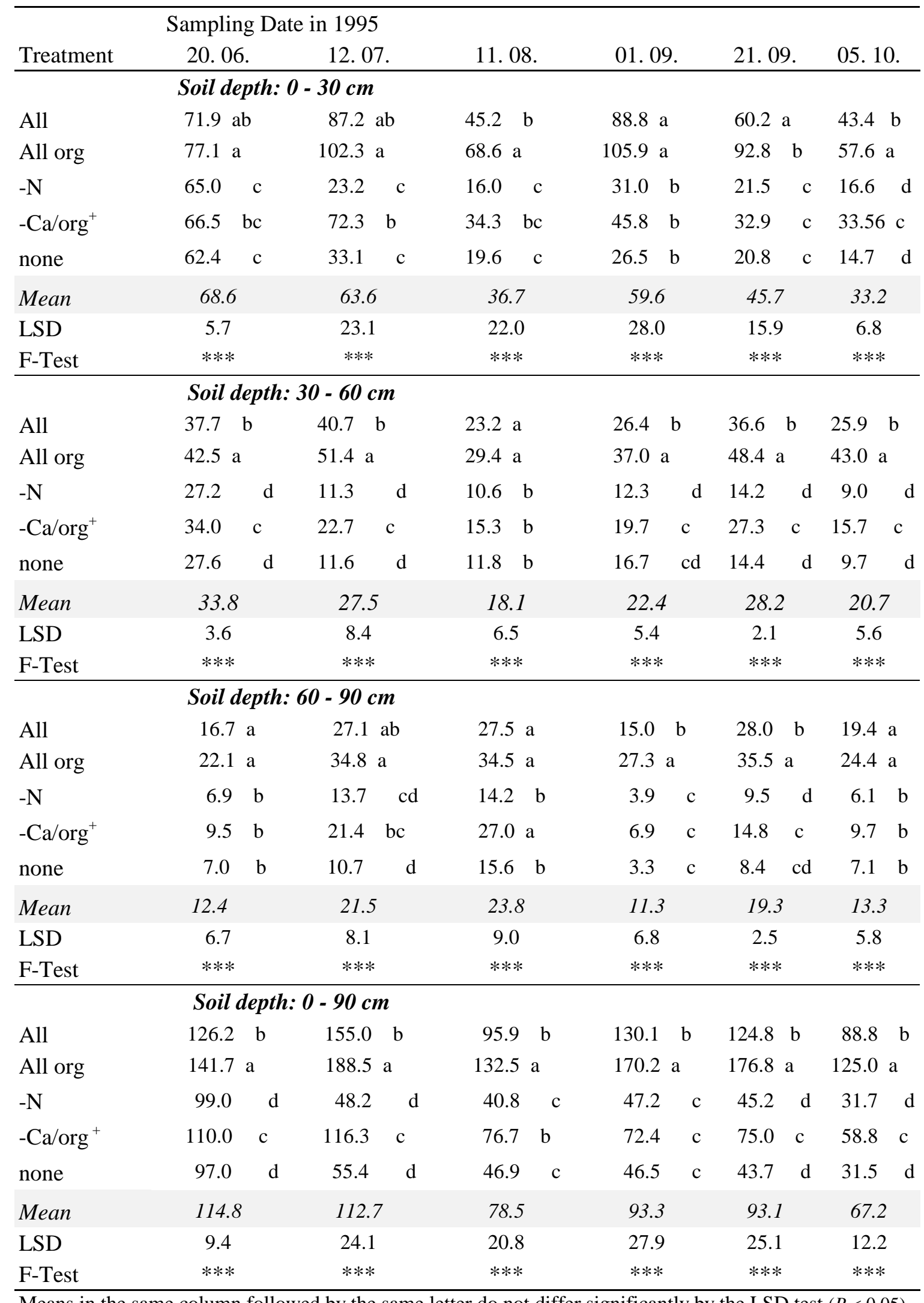


Table 63: Correlation coefficients ( $\mathrm{r}$ ) of preseason soil $\mathrm{NH}_{4}{ }^{+}, \mathrm{NO}_{3}{ }^{-}$and $\mathrm{N}_{\min }$ at the beginning of the third season $(20.06 .1995)$ in the top soil $(0-30 \mathrm{~cm})$ with selected soil characteristics at $0-30 \mathrm{~cm}$ soil depth. Locations: $\mathrm{CH} 1, \mathrm{CH} 2$.

\begin{tabular}{|c|c|c|c|c|c|c|}
\hline \multirow[b]{2}{*}{ Parameter } & \multicolumn{3}{|c|}{$\begin{array}{l}\text { CH } 1 \text { (non-degraded) } \\
\text { soil depth } 0-30 \mathrm{~cm}(\mathrm{n}=25)\end{array}$} & \multicolumn{3}{|c|}{$\begin{array}{l}\text { CH } 2 \text { (degraded) } \\
\text { soil depth } 0-30 \mathrm{~cm}(\mathrm{n}=25)\end{array}$} \\
\hline & $\mathrm{NH}_{4}^{+}$ & $\mathrm{NO}_{3}^{-}$ & $\mathbf{N}_{\min }$ & $\mathbf{N H}_{4}^{+}$ & $\mathrm{NO}_{3}^{-}$ & $\mathbf{N}_{\min }$ \\
\hline $\mathrm{NH}_{4}{ }^{+}(0-30 \mathrm{~cm})$ & nd & $0.53 * *$ & nd & nd & $0.53 * *$ & nd \\
\hline $\mathbf{C}_{\text {org }}$ & $0.04 \mathrm{~ns}$ & $0.30 \mathrm{~ns}$ & $0.28 \mathrm{~ns}$ & $0.23 \mathrm{~ns}$ & $-0.07 \mathrm{~ns}$ & $-0.01 \mathrm{~ns}$ \\
\hline total $N$ & $0.21 \mathrm{~ns}$ & $0.18 \mathrm{~ns}$ & $0.19 \mathrm{~ns}$ & $-0.04 \mathrm{~ns}$ & $0.21 \mathrm{~ns}$ & $0.18 \mathrm{~ns}$ \\
\hline C-N-ratio & $-0.19 \mathrm{~ns}$ & $-0.01 \mathrm{~ns}$ & $-0.03 n s$ & $-0.04 \mathrm{~ns}$ & $-0.25 \mathrm{~ns}$ & $-0.23 n s$ \\
\hline pH & $0.02 \mathrm{~ns}$ & $-0.21 \mathrm{~ns}$ & $-0.19 n s$ & $0.03 \mathrm{~ns}$ & $0.17 \mathrm{~ns}$ & $0.17 \mathrm{~ns}$ \\
\hline available $\mathbf{P}$ & $0.22 \mathrm{~ns}$ & $0.57 * *$ & $0.56 * *$ & $0.19 \mathrm{~ns}$ & $0.03 \mathrm{~ns}$ & $0.01 \mathrm{~ns}$ \\
\hline organic $\mathbf{P}$ & $0.56 * *$ & $0.17 \mathrm{~ns}$ & $0.22 \mathrm{~ns}$ & $0.48 * *$ & $0.41 *$ & $0.46^{*}$ \\
\hline CEC & $0.18 \mathrm{~ns}$ & $0.31 \mathrm{~ns}$ & $0.32 \mathrm{~ns}$ & $0.55 * *$ & $0.32 \mathrm{~ns}$ & $0.40 \mathrm{~ns}$ \\
\hline exchangeable $\mathrm{K}$ & $0.32 \mathrm{~ns}$ & $0.58 * *$ & $0.58 * *$ & $0.52 * *$ & $0.35 *$ & $0.41 *$ \\
\hline exchangeable Ca & $0.12 \mathrm{~ns}$ & $0.04 \mathrm{~ns}$ & $0.04 \mathrm{~ns}$ & $-0.12 \mathrm{~ns}$ & $0.01 \mathrm{~ns}$ & $-0.02 \mathrm{~ns}$ \\
\hline exchangeable Mg & $0.14 \mathrm{~ns}$ & $0.42 *$ & $0.41 *$ & $0.50 *$ & $0.22 \mathrm{~ns}$ & $0.30 \mathrm{~ns}$ \\
\hline exchangeable Zn & $0.23 \mathrm{~ns}$ & $0.38 *$ & $0.38 *$ & $0.10 \mathrm{~ns}$ & $0.18 \mathrm{~ns}$ & $0.18 \mathrm{~ns}$ \\
\hline extractable sulfate-S & $0.53 * *$ & $0.36 *$ & $0.40 *$ & $0.53 * *$ & $0.60 * *$ & $0.63^{* * * *}$ \\
\hline $\mathbf{C}_{\text {mic }}$ & $0.30^{+}$ & $0.28 \mathrm{~ns}$ & $0.30 \mathrm{~ns}$ & $0.10 \mathrm{~ns}$ & $0.29 \mathrm{~ns}$ & $0.27 \mathrm{~ns}$ \\
\hline $\mathrm{C}_{\text {mic }}-\mathrm{C}_{\text {org }}$-ratio & $0.30 \mathrm{~ns}$ & $0.13 \mathrm{~ns}$ & $0.15 \mathrm{~ns}$ & $0.04 \mathrm{~ns}$ & $0.24 \mathrm{~ns}$ & $0.21 \mathrm{~ns}$ \\
\hline $\begin{array}{l}\text { acid phosphatase ac- } \\
\text { tivity }\end{array}$ & $0.35^{+}$ & $0.56 * *$ & $0.56 * *$ & $0.44^{*}$ & $0.45 *$ & $0.48 * *$ \\
\hline $\begin{array}{l}\text { alkaline phosphatase } \\
\text { activity }\end{array}$ & $0.12 \mathrm{~ns}$ & $0.03 \mathrm{~ns}$ & $0.04 \mathrm{~ns}$ & $0.39 *$ & $0.15 \mathrm{~ns}$ & $0.21 \mathrm{~ns}$ \\
\hline ß-glucosidase activity & 0.21 & $0.34^{+}$ & $0.34^{+}$ & $0.47 *$ & $0.06 \mathrm{~ns}$ & $0.05 \mathrm{~ns}$ \\
\hline protease activity & $0.36^{+}$ & $0.28 \mathrm{~ns}$ & $0.30 \mathrm{~ns}$ & $-0.09 \mathrm{~ns}$ & $0.38^{+}$ & $0.32^{+}$ \\
\hline
\end{tabular}


Table 64: One-way ANOVA on estimates of potential $\mathrm{N}$ mineralization (pot- $\mathrm{N}_{\min }$ ) based on 7 days of anaerobic incubation in soil layers of $0-30 \mathrm{~cm}, 30-60 \mathrm{~cm}$, and $60-90 \mathrm{~cm}$. Locations: $\mathrm{CH} 1$ (not degraded) and CH 2 (degraded). Sampling dates: 20. 06. 95 and 11.08. 95.

\begin{tabular}{|c|c|c|c|c|c|c|c|c|}
\hline \multirow[t]{2}{*}{ Treatment } & \multicolumn{4}{|c|}{ Sampling depth (cm) } & \multicolumn{4}{|c|}{ Sampling depth (cm) } \\
\hline & $\mathbf{0}-\mathbf{3 0}$ & $30-60$ & $60-90$ & 0 - 90 & 0 - 30 & $30-60$ & $60-90$ & 0 - 90 \\
\hline & $\mathrm{CH} 1$ & 20.06 .95 & & & $\mathrm{CH} 1$ & 11.08 .95 & & \\
\hline All & 14.5 & 6.1 & 2.1 & 22.7 & 16.1 & 5.3 & 0.70 & 22.1 \\
\hline All org & 20.9 & 7.8 & 2.9 & 31.5 & 22.4 & 7.7 & 0.50 & 30.5 \\
\hline$-\mathbf{N}$ & 13.6 & 2.9 & 0.9 & 17.3 & 13.0 & 3.0 & -0.30 & 15.6 \\
\hline org & 13.7 & 6.9 & 2.0 & 22.6 & 16.7 & 6.3 & -0.01 & 23.0 \\
\hline none & 9.1 & 2.3 & 0.9 & 12.4 & 10.8 & 2.6 & 0.02 & 13.5 \\
\hline Mean & 14.4 & 5.2 & 1.8 & 21.3 & 15.8 & 5.0 & 0.2 & 20.9 \\
\hline LSD & 5.2 & 2.1 & 0.5 & 5.8 & 3.8 & 4.0 & 0.6 & 6.6 \\
\hline F-Test & $* *$ & $* * *$ & $* * *$ & $* * *$ & $* * *$ & + & $*$ & $* * *$ \\
\hline
\end{tabular}

CH 20.06 .95

$\mathrm{CH} 2 \quad 11.08 .95$

\begin{tabular}{lcccccccc} 
All & 15.9 & 4.5 & -0.4 & 20.0 & 13.8 & 3.9 & 0.3 & 18.0 \\
All org & 16.8 & 7.5 & -0.4 & 23.9 & 19.9 & 7.4 & 1.0 & 28.3 \\
-N & 12.2 & 2.9 & -0.5 & 14.6 & 9.4 & 1.1 & -0.2 & 10.3 \\
org & 14.3 & 4.4 & 0.02 & 18.7 & 12.9 & 3.7 & 0.1 & 16.8 \\
none & 11.8 & 1.8 & -0.5 & 13.1 & 10.4 & 0.2 & 0.2 & 10.8 \\
Mean & 14.2 & 4.2 & -0.4 & 18.1 & 13.3 & 3.3 & 0.3 & 16.8 \\
LSD & 1.6 & 1.7 & 0.9 & 2.3 & 6.9 & 2.2 & 1.1 & 7.1 \\
F-Test & $* * *$ & $* * *$ & ns & $* * *$ & $*$ & $* * *$ & ns & $* * *$ \\
\hline
\end{tabular}




\section{Acknowledgments}

My sincere gratitude goes to Prof. Dr. P.L.G. Vlek for the initiation of this research, for his guidance, valuable advises and constructive suggestions and comments.

I would also like to thank Prof. Dr. H. Fölster from the Institute of Soil Science and Forest Nutrition, University of Göttingen for being the co-referee.

I would like to express my thanks to Dr. Ronald Kühne for his helpful and constructive suggestions, critical comments and assistance during the studies.

I would like to thank all my colleagues and staff at the Institute of Agronomy in the Tropics, University of Göttingen for support and discussions and for reliable and good ideas in the laboratory.

I would like to thank Dr. R.G. Joergensen for his support in training lab staff from SARI and giving necessary information for successful laboratory works.

I would like to express my sincere thanks to GTZ staff at SARI for giving me support and help at any time during my stay in Ghana: Dr. Rudat, Dr. Albert and Mr. Ohlemacher.

I would like to express my sincere thanks to the staff at SARI for providing the infrastructure, for supporting me during field work and laboratory analysis and for providing technical assistance.

I would like to express my sincere thanks to the farmers for kindly providing experimental sites and to the permanent and casual laboratory and field workers for supporting me during field works and laboratory analysis: Anthony Quarshie, Emanual Vorleto, Willi Obikyenba, Frank Gberika, Apiah Sulemana, Mohamed Saibu, Adam Abdul Rahman, Salifu Sulemana, Abu Achulo, Samed Jacobu, Jacobu Rahman, A. Issahaku, James Apaseku, John Ahiekpor, Joseph Arhin, Al Hassan Issahaku and all the others.

I would like to express my sincere thanks to Andrea Jost for her valuable help, for good discussions and having good times in Nyankpala.

I also like to thank my friends for the constant presence and moral support.

Special thanks to my family for moral support and encouragement and to my wife Alice in particular for her patience and supporting me in all the time. A very special thanks to my children for their understanding that there was not much time left to spent with them, especially during the last stage of the study. I would like to dedicate this work to them.

Finally I thank the "Gesellschaft für Technische Zusammenarbeit" (GTZ) for financing this work within the framework of the "Tropical Ecology Support Program" (TOEB). 


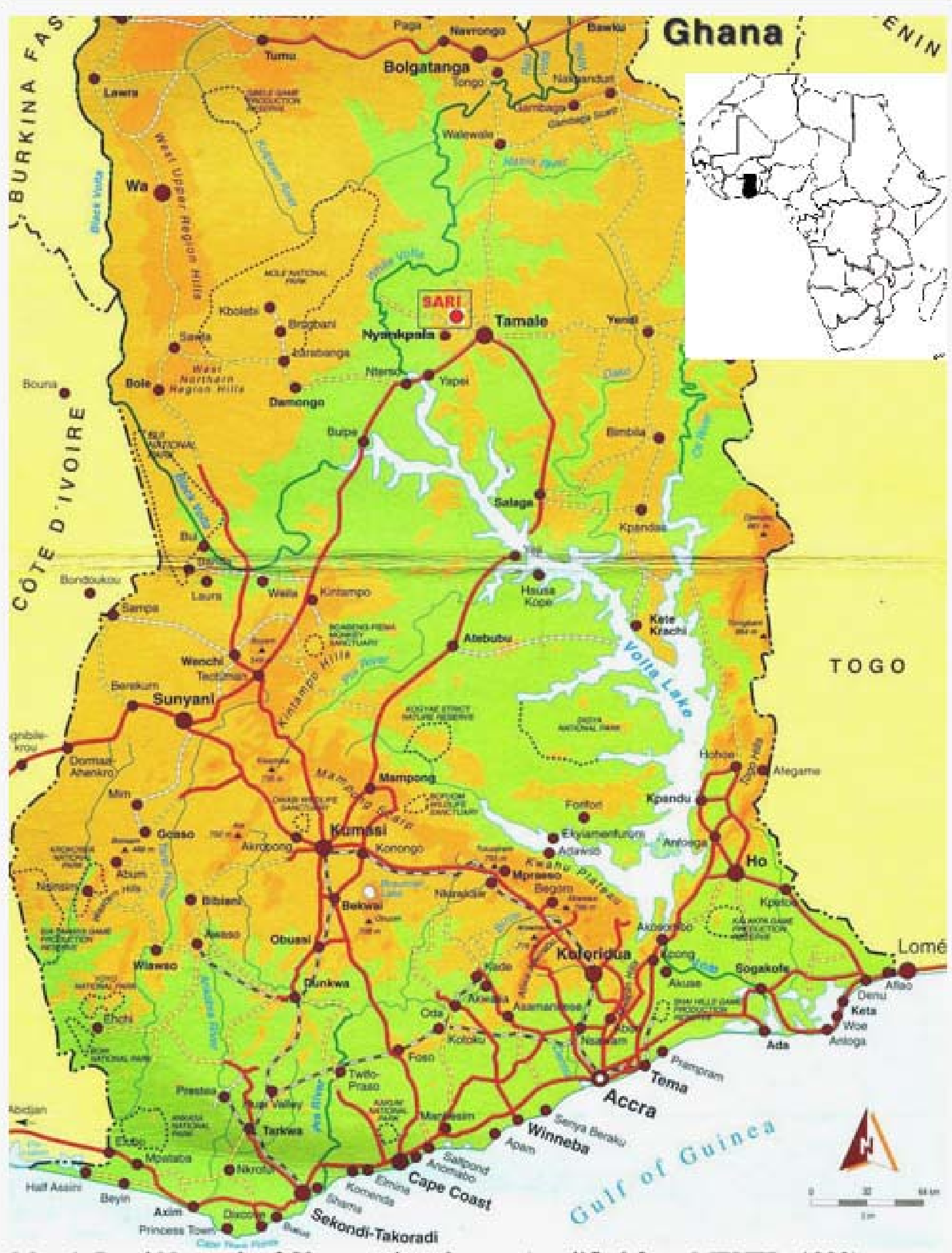

Map 1: Road Network of Ghana and study area (modified from MEYER, 1993). 